\title{
Site C0012
}

\author{
Expedition 333 Scientists $^{2}$
}

\section{Chapter contents}

Background and objectives.......... 1

Operations...................

Lithology ..................

Structural geology.............6

Biostratigraphy .............. 8

Paleomagnetism ............... 9

Physical properties .............. 11

Inorganic geochemistry ........... 13

Organic geochemistry............ 16

Igneous petrology............. 17

References.................... 18

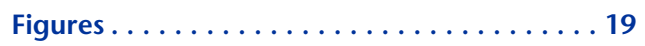

Tables.................... 71

${ }^{1}$ Expedition 333 Scientists, 2012. Site C0012. In Henry, P., Kanamatsu, T., Moe, K., and the Expedition 333 Scientists, Proc. IODP, 333: Tokyo (Integrated Ocean Drilling Program Management International, Inc.).

doi:10.2204/iodp.proc.333.105.2012

'Expedition 333 Scientists' addresses.

\section{Background and objectives}

Integrated Ocean Drilling Program (IODP) Expeditions 322 and 333 were designed to document characteristics of incoming sedimentary strata and uppermost igneous basement prior to their arrival at the subduction front (Saito et al., 2010). To accomplish this objective, coring was conducted at two sites on the subducting Philippine Sea plate. IODP Site C0011 is located on the northwest flank of a prominent bathymetric high (the Kashinosaki Knoll; Ike et al., 2008), whereas IODP Site C0012 is located near the crest of the knoll (Fig. F1). Data acquired during Expedition 322 and logging-while-drilling data at Site C0011 acquired during IODP Expedition 319 provide new information on presubduction equivalents of the seismogenic zone (Underwood et al., 2010). After jetting-in to $\sim 70$ meters below seafloor (mbsf), rotary core barrel (RCB) coring at Site C0012 penetrated almost $23 \mathrm{~m}$ into igneous basement and recovered the sediment/basalt interface intact at 537.81 mbsf. The merger of lithofacies and age-depth models shows how correlative units change from an expanded section at Site C0011 to a condensed section at Site C0012 (Fig. F2). The age of basal sediment (reddish-brown pelagic claystone) at Site C0012 is older than $18.9 \mathrm{Ma}$. Geochemical analyses of interstitial water on top of the basement high show clear evidence of upward diffusion of sulfate and other dissolved chemical species from the basement (Underwood et al., 2010). The depth of the sulfate reduction zone is also anomalously deep at Site C0012. Chlorinity values increase toward basement because of hydration reactions in the sediment and diffusional exchange with basement fluids. In contrast to Site C0011, where chlorinity decreases with depth, the more saline fluids at Site C0012 appear largely unaffected by focused flow and/or in situ dehydration reactions associated with rapid burial beneath the trench wedge and frontal accretionary prism. Thus, Site C0012 is thought to provide a reliable geochemical reference site, unaffected by subduction processes.

The specific questions addressed by additional drilling at input sites are

- Is fluid circulation in basement and permeable sedimentary layers influencing heat flow and diagenesis at Sites C0011 and C0012?

- How does contrasting interstitial fluid chemistry at Sites C0011 and C0012 relate with in situ diagenesis and fluid flow? 
- Can a change of physical properties between 200 and 250 mbsf at Site C0011 be related to lithologic variation or silica diagenesis? Does the same transition occur at Site C0012?

- Was magmatic activity heterogeneous in composition and age on the backarc basin basement high (Kashinosaki Knoll)?

- Is alteration of the upper oceanic basement heterogeneous and how does such alteration influence geochemical and fluid budgets?

The main objectives of returning to Site C0012 were to perform temperature measurements for heat flow determination, to expand the age-depth models into the Pliocene and Quaternary, and to core the basement to at least $100 \mathrm{~m}$ below the sediment/basement interface. Knowledge of thermal state, interstitial water geochemistry, hydrologic properties, and basement alteration are needed to characterize the state of the subduction inputs and model their evolution with downdip increases in temperature and pressure.

\section{Operations}

Without picking up the transponders from Site C0011, the D/V Chikyu moved to Site C0012 after the coring assembly was retrieved on board at $1930 \mathrm{~h}$ on 24 December 2010. Transit in dynamic positioning (DP) mode over a distance of $5 \mathrm{nmi}$ at $5 \mathrm{kt}$ finished at 2030 h. From 2200 h, transponders were dropped, set at four different locations, and calibrated. The location was set at $0815 \mathrm{~h}$ on 25 December upon completion of DP calibration.

The hydraulic piston coring system (HPCS)/extended punch coring system (EPCS)/extended shoe coring system (ESCS) coring assembly was made up and run into Hole C0012C to $3528 \mathrm{~m}$ drilling depth below rig floor (DRF). After tagging the seafloor at $3539.0 \mathrm{~m}$ DRF at $1600 \mathrm{~h}$, HPCS coring began at $1630 \mathrm{~h}$ (Table T1). After coring the eleventh core, a hydraulic power swivel motor malfunction caused a delay from 1300 to $1500 \mathrm{~h}$ on 26 December. After coring the fifteenth core at $2130 \mathrm{~h}$, the core wire parted when the sinker bar assembly was overloaded. Hence, the sinker bar fell to the bottom of the hole and the damaged core line was cut at $\sim 100 \mathrm{~m}$. The hole was abandoned after spotting kill mud.

The Chikyu moved to Hole C0012D while waiting on weather from 0600 to $0800 \mathrm{~h}$ on 27 December. Test coring was done at the seafloor at $1000 \mathrm{~h}$, washed down to 20 mbsf at $1330 \mathrm{~h}$, and then drilled to 118 mbsf. HPCS coring began at $1745 \mathrm{~h}$ and continued to $180 \mathrm{mbsf}$, where strong wind caused ship offset by $\sim 16 \mathrm{~m}$ and stopped coring in this hole. We pulled out of Hole C0012D to above the seafloor at $1900 \mathrm{~h}$ and waited on weather.

The Chikyu moved to Hole C0012E, and the decision was made to drill down and core the sediment/basement interface with the ESCS to make the best use of a short good weather window. Hole C0012E was spudded at $1030 \mathrm{~h}$ on 29 December, washed down to $28.5 \mathrm{mbsf}$, and then drilled to $500 \mathrm{mbsf}$, which was reached at $1045 \mathrm{~h}$ on 30 December.

After preparation for coring, the first ESCS core was taken at $1415 \mathrm{~h}$ and coring continued to $528.5 \mathrm{mbsf}$. Coring was stopped at $2245 \mathrm{~h}$ because of deterioration of the weather, and the bottom-hole assembly (BHA) was pulled out of hole.

Making up the RCB coring assembly for Hole C0012F started at $0230 \mathrm{~h}$ on 1 January 2011 while waiting on weather. The BHA was run to $3530 \mathrm{~m} \mathrm{DRF}$, spudded at $1315 \mathrm{~h}$, and drilled to 520 mbsf. RCB coring began at $1500 \mathrm{~h}$ on 2 January but ended at $1930 \mathrm{~h}$ after the second core was taken because of abnormal pressure while coring. After cleaning the outer core barrel and the hole, the center bit assembly was set for a circulation test. The test was successful, but the center bit assembly could not be retrieved because the pull bar broke, which ended coring operations in Hole C0012F.

Pulling out of the hole took place between 0730 and $1615 \mathrm{~h}$ on 3 January. The RCB coring assembly for Hole C0012G was made with a roller cone bit after finding that more than half of the teeth on the polycrystalline diamond compact (PDC) drill bit used in Hole C0012F were worn out. Running pipe down started at 1815 h on 3 January, and Hole C0012G was spudded at $0900 \mathrm{~h}$ on 4 January. We drilled to 515 mbsf and began RCB coring with full advance at 1315 h on 5 January. Full advance coring continued to 591 mbsf with medium to poor recovery. We then switched to a shorter advance to improve core recovery to $630.5 \mathrm{mbsf}$, except for one full advance core (333-C0012G-11R). Coring in Hole C0012G ended at $1545 \mathrm{~h}$ on 7 January, and kill mud spotting and pulling out of the hole lasted until $0330 \mathrm{~h}$ on 8 January.

Coring operations were disturbed twice by short intervals of low-pressure weather. In addition to weather, two incidents forced us to pull out of the hole: a parted core wire and a parted center bit at the bottom. Core quality and recovery varied depending on the formation or lithology and also the corer and drill bit types.

Core recovery was excellent for the piston cores in Holes C0012C and C0012D, with average rates of $103.3 \%$ and $104 \%$, respectively, which presents a marked improvement in quality from Expedition 322 RCB coring. In comparison to Site C0011, cores 
from Site C0012 had almost constant recovery without broken cores or becoming jammed. However, Cores 333-C0012D-8H to $13 \mathrm{H}$ (bottom of Hole C0012D) were affected by coring disturbance (flowin and stretching). The ESCS was used in Hole C0012E to core only at the sediment/basement interface and yielded the best quality cores compared to three other attempts with the RCB. Core 333C0012E-3X, especially, which penetrated through red calcareous claystone/pillow basalt, has quite long $(>50 \mathrm{~cm})$ coherent pieces in places. Interpillow glasses of pillow basalt are well preserved at the bottom part of the same core. Average recovery was $48.6 \%$, ranging from $11.4 \%$ to $87.9 \%$. Holes C0012F and $\mathrm{C} 0012 \mathrm{G}$ used RCB coring but with different bits. $\mathrm{RCB}$ coring with a damaged PDC bit in Hole C0012F yielded two cores with an average recovery of $48.2 \%$. Hole C0012G was cored deep into the basaltic basement with a roller cone bit. Core recovery was $22.4 \%$ on average, varying between $9.6 \%$ and $45.8 \%$ for the full advance cores and between $4.1 \%$ and $73.2 \%$ for the half advance in the deeper part of the hole.

\section{Lithology}

In Holes C0012C and C0012D, $180 \mathrm{~m}$ of lithologic Unit I and the upper part of lithologic Unit II were drilled during Expedition 333. Holes C0012E, C0012F, and C0012G aimed at recovering the boundary between sediments in the Shikoku Basin and the igneous oceanic crust and deepening penetration into the basalt. The age of these units and their boundaries are known from Expedition 322, which cored Hole C0012A from 60 to 576.0 mbsf (Expedition 322 Scientists, 2010). However, the quality of RCB cores and core recovery in the upper part of Hole C0012A were not good enough to provide a complete and reliable description of Units I and II.

During Expedition 333, sediments belonging to Unit I and the upper part of Unit II were cored with the HPCS with very good recovery. Thus, the new holes added information on upper Shikoku Basin strata not acquired during Expedition 322 (Expedition 322 Scientists, 2010). Three lithologic subunits were interpreted within Unit I during the examination of cores (Fig. F3).

\section{Lithologic Unit I (hemipelagic/pyroclastic facies)}

Interval: Sections 333-C0012C-1H-1, $0.0 \mathrm{~cm}$, through 333-C0012D-6H-4, $98 \mathrm{~cm}$

Depth: Hole C0012C/C0012D = 0.00-149.77 mbsf

Age: Holocene-Miocene
Subunits in Unit I are distinguished based on the abundance and thickness of volcanic ash layers within a background of hemipelagic mud. Lithologies in Holes C0012C and C0012D include dark greenish gray clay, silty clay, and clayey silt interbedded with generally fine volcanic ash (Figs. F3, F4; see Site C0012 smear slides in "Core descriptions"). A major change in the frequency of the occurrence of ash layers is recorded around 71.5 mbsf, marking the Subunit IA/IB boundary (Fig. F3). Underneath Subunit IA, ash layers are scarce to $\sim 123$ mbsf (Subunit IB) (Fig. F3). Below 123 mbsf, another interval of dark greenish gray silty clay with abundant ash layers extends to the base of Unit I at $\sim 149.77$ mbsf. This lower interval is assigned as Subunit IC. A more detailed description of these subunits is presented below.

\section{Subunit IA}

Interval: Sections 333-C0012C-1H-1, $0.0 \mathrm{~cm}$, through $9 \mathrm{H}-2,62 \mathrm{~cm}$

Depth: Hole C0012C/C0012D $=0.00-71.54 \mathrm{mbsf}$

Age: Holocene-lower Pliocene

Subunit IA comprises a $71.5 \mathrm{~m}$ thick succession dominated by dark greenish gray clay to silty clay. The top $3 \mathrm{~m}$ is light brown-yellowish gray. Intercalated are 1-2 cm thick green bands enriched in iron, analogous to what has been observed and analyzed by means of X-ray fluorescence (XRF) core logging at Site C0011 (see Fig. F6 in the "Site C0011" chapter [Expedition 333 Scientists, 2012b]), and $<40 \mathrm{~cm}$ thick ash layers (Figs. F4, F5). The subunit is moderately or heavily bioturbated, and the ichnofossil genus Chondrites is abundant. Scattered ash is observed throughout the succession within intervals of $<1 \mathrm{~cm}$ to several tens of centimeters in thickness (Fig. F5).

Clay minerals and nannofossils are the most abundant particles on smear slides, with accessory percentages of volcanic glass and quartz. Siliceous fossils such as sponge spicules, diatoms, and radiolarians occur as a rare or trace component in most of Subunit IA, being relatively more abundant at the top of this subunit (see Site C0012 smear slides in "Core descriptions"). Wood fragments occur in interval 333-C0012C-2H-2, 48-59 cm, at 6.3-6.4 mbsf.

An ash layer that appears to be equivalent to the onland Azuki volcanic ash bed $(0.85 \mathrm{Ma}$; Hayashida et al., 1996) was identified at 5.70 mbsf (interval 333C0012C-2H-1, 118-132 cm), based on positive identification of characteristic microscopic features such as abundant bubble wall type glass shards with a few obsidian fragments and orthopyroxene and clinopyroxene crystals (Fig. F6; see Site C0012 smear slides in "Core descriptions"). A tentative correlative to 
the onland Pink volcanic ash bed (1.05 Ma; Hayashida et al., 1996) occurs at 7.70 mbsf (interval 333C0012C-2H-3, 40-73 cm) (Fig. F6; see Site C0012 smear slides in "Core descriptions"), as inferred from the occurrence of characteristic microscopic features such as fibrous bubble wall type glass shards and abundant hornblende minerals, which are distinct from other ash layers. A third major volcaniclastic event deposit, the Ohta volcanic ash bed (4.0 Ma; Satoguchi et al., 2005), appears to match a cored ash layer at 44.95 mbsf (interval 333-C0012C-6H-2, 120-124 cm), which contains bubble junction type glass shards and biotite (see Site C0012 smear slides in "Core descriptions") typical of this volcanic marker bed. In addition, large pumice pebbles $(>2$ $\mathrm{cm}$ in diameter) are present in interval 333-C0012C$8 \mathrm{H}-3,22-32 \mathrm{~cm}$, at $\sim 62.8 \mathrm{mbsf}$.

The deposition of Subunit IA occurred over a basement high (Kashinosaki Knoll) dominated by hemipelagic settling and ash from volcanic eruptions. The Subunit IA/IB boundary is marked by the transition to an interval where ash layers become scarce and is defined at the base of the last downsection occurrence of a thick ash layer at 71.54 mbsf (Section 333C0012C-9H-2, $62 \mathrm{~cm}$ ). Remarkably, there is a significant age gap in the upper part of Subunit IA at 14 msbf (see "Biostratigraphy" and "Paleomagnetism"), which is overlain by a $4 \mathrm{~m}$ thick interval showing evidence for disturbance from both drilling and in situ deformation (Fig. F5). Below this is a $62.5 \mathrm{~m}$ thick interval with tilted strata (Fig. F5; see also "Structural geology"). This suggests that a significant portion of the stratigraphic succession of Subunit IA and the upper part of Subunit IB is affected by slumping (see "Structural geology").

\section{Subunit IB}

Interval: Sections 333-C0012C-9H-2, $62 \mathrm{~cm}$, through 333-C0012D-2H-7, $87 \mathrm{~cm}$

Depth: Hole C0012C/C0012D = 71.54-123.31 mbsf

Age: lower Pliocene-upper Miocene

Subunit IB is a heavily bioturbated dark greenish gray silty clay with minor contributions of volcanic ash (Figs. F3, F4). Tilted colored bands and ash layers are seen in the uppermost part of the subunit. Below $\sim 81.63 \mathrm{mbsf}$ is a $\sim 4.5 \mathrm{~m}$ thick zone of chaotic bedding (see "Structural geology"). Clay minerals, nannofossils, and altered volcanic glass are the most abundant particles on smear slides, with accessory percentages of quartz and opaque minerals (see Site C0012 smear slides in "Core descriptions"). Other microfossils are absent from the subunit.

The subunit is dominated by hemipelagic settling with rare ash intercalations from volcanic eruptions.
The upper part of this unit has been affected by slumping (see "Structural geology"). A smear slide from 91.19 mbsf (Section 333-C0012C-11H-5, 30 $\mathrm{cm})$ provides the first downsection observation of altered volcanic ash (Fig. F7). The last smear slide observation of fresh glass is from Section 333-C0012C7H-8, $17 \mathrm{~cm}$ (59.24 mbsf, within the lower part of Subunit IA) (Fig. F7). Due to a gap in shipboard observation of volcanic ash in smear slides between 60 and 90 mbsf (i.e., the interval also characterized by the base of the slumped section [see "Structural geology"]), the exact depth of ash alteration remains undefined and may or may not correlate with (1) the Subunit IA/IB boundary, as a similar change in the degree of alteration of ash has been recorded at the Subunit IA/IB boundary in Hole C0011C at 251.52 mbsf (see "Lithology"), and/or (2) changes in physical properties (see "Physical properties") and inorganic geochemistry (see "Inorganic geochemistry") that occur more progressively from the top of Subunit IB to $\sim 100$ mbsf. The Subunit IB/IC boundary is marked by more frequent appearance of ash layers and is defined at the top of an ash layer at 123.31 mbsf (Section 333-C0012D-2H-7, $87 \mathrm{~cm}$ ).

\section{Subunit IC}

Interval: Sections 333-C0012D-2H-7, $87 \mathrm{~cm}$, through $6 \mathrm{H}-4,98 \mathrm{~cm}$

Depth: Hole C0012D = 123.31-149.77 mbsf

Age: upper Miocene

Subunit IC comprises heavily bioturbated dark greenish gray silty clay. The characteristic feature of this unit is the relative increase in the content of volcanic glass, which is higher than within the overlying subunit. Intercalated in the subunit are $<20 \mathrm{~cm}$ thick ash layers, which contain altered glass as observed in smear slides (see Site C0012 smear slides in "Core descriptions") and green bands inferred to be enriched in iron analogous to what has been observed and analyzed by means of XRF core logging at Site C0011 (see Fig. F6 in the "Site C0011" chapter [Expedition 333 Scientists, 2012b]). Scattered ash is observed throughout the succession (see Site C0012 smear slides in "Core descriptions"). Smear slides indicate that clay minerals remain the most abundant particles. Accessory components include quartz and nannofossils (see Site C0012 smear slides in "Core descriptions"). The other detrital constituents appear as trace percentages in most of the subunit.

Deposition of Subunit IC was dominated by hemipelagic settling with contribution from a volcanic source. The Unit I/II boundary is marked by the first occurrence of a semiconsolidated sandy volcanic turbidite at 149.77 mbsf (Section 333-C0012D-6H-4, 98 
$\mathrm{cm})$ and correlates to the Unit I/II boundary cored in Section 322-C0012A-12R, 43cm (150.86 mbsf) (Expedition 322 Scientists, 2010). Below this depth, background sediment in Unit II is finer than that recorded over the same depth interval by Expedition 322 in Hole C0012A, with coarser grained material (including calcite-rich gravel) appearing below 173.9 mbsf.

\section{Lithologic Unit II (volcanic turbidite facies)}

Interval: Sections 333-C0012D-6H-4, $98 \mathrm{~cm}$, through 13H-CC, $25 \mathrm{~cm}$

Depth: Hole C0012D = 149.77-179.96 mbsf

Age: upper Miocene

The upper part of Unit II comprises semiconsolidated sandy volcanic turbidites with sharp and welldefined upper and lower boundaries. In the lower part of the unit they appear as more consolidated volcanic sandstone turbidites, including fresh and altered glass with some associated calcite (see Site C0012 smear slides in "Core descriptions"). Commonly, beds have normal grading, but some intervals are massive and may contain clay clasts $1-10 \mathrm{~cm}$ in diameter (Fig. F8). The lowermost conglomerate bed in Core 333-C0012D-13H is composed of disaggregated pieces of volcaniclastic sandstone and bioturbated silty claystone showing evidence for sediment remobilization (see also "Structural geology"), likely correlating to a chaotic interval in Hole C0012A (178-181.1 mbsf) (Expedition 322 Scientists, 2010). Some of the sand layers in Unit II present fractures filled with magnesium-rich calcite and traces of barite.

During the deposition of the upper part of Unit II, the paleoenvironment was dominated by deposition from a sandy system as described and interpreted in more detail by the Expedition 322 Scientists (2010). The probable source of the volcanic sand was the Izu-Bonin volcanic arc. The top of the volcanic turbidite facies (Unit II) cored in Holes C0012D (at 149.77 mbsf) and C0012A (at 150.86 mbsf) (Expedition 322 Scientists, 2010) is $\sim 7.8 \mathrm{Ma}$ in age (see "Biostratigraphy" and "Paleomagnetism") and thus is time correlated to the top of the volcanic turbidite facies (Unit II) cored in Holes C0011B and C0011D (see "Lithology," "Biostratigraphy," and "Paleomagnetism" in the "Site C0011" chapter [Expedition 333 Scientists, 2012b]). However, in comparison to Site C0011 the Miocene sandy volcanic turbidites are finer grained at Site C0012, likely because the site of deposition rests on the crest of the Kashinosaki Knoll. The bathymetric high was not large enough at the time of deposition, however, to prevent the transport and deposition by turbidity currents (see also the detailed discussion in Expedition 322 Scientists, 2010).

\section{Sediment/Basement contact}

Two cores recovered from Hole C0012E (Cores 333C0012E-1X and 2X) were greenish silty claystone intercalated with thin sandstone layers from 500 to 510.5 mbsf. This interval corresponds to the base of lithologic Unit V (volcaniclastic-rich facies) defined during Expedition 322 (see Expedition 322 Scientists, 2010, for detailed description and interpretation of this facies). The first consistent occurrence of reddish brown calcareous claystone corresponding to lithologic Unit VI (pelagic claystone) (Expedition 322 Scientists, 2010) occurs at the top of Core 333C0012E-3X (519 mbsf), overlying the sediment/basaltic basement contact cored in Section 333C0012E-3X-7, $114 \mathrm{~cm}$ (525.815 mbsf) (see also "Igneous petrology"). Unit VI pelagic claystone facies was also recovered as broken, drilling-disturbed pieces in Hole C0012F, from the top of the cored section to the sediment/basaltic basement contact in Section 333-C0012F-1R-1, $46 \mathrm{~cm}$, and as a continuous section in Hole C0012G, from the top of the cored section to the sediment/basement contact in Section 333-C0012G-2R-2, $80 \mathrm{~cm}$ (see also "Igneous petrology"). The calcareous claystone is rich in nannofossils with minor amounts of radiolarian spines and is interpreted to represent a thin veneer of pelagic sediments overlying the basement (see also Expedition 322 Scientists, 2010). Locally, the claystones have a mottled red-green coloration. They also hold veins of calcite with traces of barite as well as several layers with accumulations of manganese oxide forming millimeter- to centimeter-sized lumps. XRF core logger data show relative variations of calcium anticorrelated with silicium and aluminium variations (Fig. F9). These likely represent variations in the biogenic calcium carbonate input. The sediment immediately above the basalt appears relatively calcium rich and aluminium and magnesium poor, suggesting a lower clay content. The basalt appears, unsurprisingly, to have higher titanium, magnesium, and iron and lower potassium compared to the sediment. An interval of manganese oxide accumulation in the sediment is found between 523.2 and 525.5 mbsf.

\section{X-ray diffraction}

X-ray diffraction (XRD) data for Subunit IA (Fig. F10; Table T2) indicate an average clay mineral content of $63 \mathrm{wt} \%$, with the lowest content characterizing the uppermost $15 \mathrm{~m}$. Quartz content shows uniform values throughout the subunit with an average of $\sim 19$ $\mathrm{wt} \%$. Calcite content is highest in the upper $15 \mathrm{~m}$, 
where it reaches $\sim 25 \mathrm{wt} \%$. Below $15 \mathrm{~m}$, calcite content of Subunit IA is very low, dropping the average for the subunit to $4 \mathrm{wt} \%$.

In Subunit IB, clay mineral content is relatively stable and averages $66 \mathrm{wt} \%$ (Fig. F10; Table T2). Quartz and feldspar contents are also stable and average 17 and $12 \mathrm{wt} \%$, respectively. Calcite is present in the subunit, varying from 0 to $20 \mathrm{wt} \%$ in relative abundance. However, it averages only $6 \mathrm{wt} \%$ in the entire Subunit IB.

XRD data for Subunit IC indicate an average clay mineral content of $72 \mathrm{wt} \%$. There is on average $\sim 18$ wt $\%$ quartz and feldspar. Calcite content varies from 0 to $5 \mathrm{wt} \%$ in relative abundance (Fig. F10; Table T2).

The relative clay mineral abundance in Unit II remains stable relative to that of Subunit IC (Fig. F10; Table T2). Quartz content is also similar to Subunit IC at $17 \mathrm{wt} \%$ on average. Feldspar values vary from 10 to $22 \mathrm{wt} \%$, averaging $13 \mathrm{wt} \%$ in Unit II, which is also similar to Subunit IC. Calcite is residual at only $1 \mathrm{wt} \%$ on average.

\section{X-ray fluorescence}

Discrete XRF analyses were performed on 28 samples from Holes C0012C and C0012D to estimate the bulk chemical composition of the sediments and to characterize compositional trends with depth and/or lithologic characteristics (see Fig. F11; Table T3). The major element composition of Units I and II is fully consistent with the XRF results obtained during Expedition 322 at Site C0012 (Expedition 322 Scientists, 2010) (Fig. F11). As for the underlying units, major element concentrations of Units I and II span a relatively small range of values and resemble those of the upper continental crust as defined by Taylor and McLennan (1985).

\section{Unit I: hemipelagic/pyroclastic facies}

In the uppermost $15 \mathrm{~m}$ of Unit $\mathrm{I}$, $\mathrm{CaO}$ content significantly decreases with depth while $\mathrm{SiO}_{2}, \mathrm{Al}_{2} \mathrm{O}_{3}$, $\mathrm{Fe}_{2} \mathrm{O}_{3}, \mathrm{~K}_{2} \mathrm{O}, \mathrm{MgO}, \mathrm{Na}_{2} \mathrm{O}$, and $\mathrm{TiO}_{2}$ contents show an overall increasing trend (Fig. F11; Table T3). These variations may reflect a dilution effect by carbonates as suggested by the decreasing proportions of calcite and increasing proportions of clays observed by XRD (Fig. F10). Excluding one outlier sample at 105.33 mbsf, $\mathrm{K}_{2} \mathrm{O}, \mathrm{TiO}_{2}$, and $\mathrm{P}_{2} \mathrm{O}_{5}$ show no significant variation with depth below $\sim 20 \mathrm{mbsf}$, with average values of $3.07 \mathrm{wt} \%$ for $\mathrm{K}_{2} \mathrm{O}, 0.67 \mathrm{wt} \%$ for $\mathrm{TiO}_{2}$, and 0.09 wt $\%$ for $\mathrm{P}_{2} \mathrm{O}_{5}$. $\mathrm{SiO}_{2}$ content is slightly scattered but gently increases throughout Unit $\mathrm{I}$, whereas $\mathrm{MgO}$ and $\mathrm{Na}_{2} \mathrm{O}$ concentrations show a gradually decreasing trend (Fig. F11; Table T3). $\mathrm{CaO}, \mathrm{Al}_{2} \mathrm{O}_{3}$, and $\mathrm{Fe}_{2} \mathrm{O}_{3}$ contents are relatively variable throughout Unit I, possibly due to a dilution effect. The higher $\mathrm{CaO}$ content observed in the lower part of the unit can be related to higher abundances of calcite as suggested by XRD data (Fig. F10). MnO concentration appears fairly uniform in the upper part of Unit I but significantly scatters below $\sim 60$ mbsf where $\mathrm{CaO}$ content is higher. Such a scattering in $\mathrm{MnO}$ concentration may account for the presence of rhodochrosite $\left(\mathrm{MnCO}_{3}\right)$ as suggested by Expedition 322 Scientists (2010) to explain the high $\mathrm{MnO}$ content measured in a few calcareous sediments at Site C0012. In the same depth interval, at $105.33 \mathrm{mbsf}$, one outlying sample shows higher $\mathrm{CaO}(12.1 \mathrm{wt} \%)$ and $\mathrm{P}_{2} \mathrm{O}_{5}(0.28 \mathrm{wt} \%)$ concentrations together with relatively low $\mathrm{SiO}_{2}$, $\mathrm{K}_{2} \mathrm{O}$, and $\mathrm{MgO}$ contents (Fig. F11; Table T3). This difference can be related to the presence of apatite $\left(\mathrm{Ca}\left[\mathrm{PO}_{4}\right]_{3}[\mathrm{~F}, \mathrm{Cl}, \mathrm{OH}]\right)$.

\section{Unit II: volcanic turbidite facies}

No significant difference in major element composition is observed between Units I and II (Fig. F11; Table T3). As in the overlying unit, one sample of hemipelagic mud shows high $\mathrm{CaO}, \mathrm{MnO}$, and $\mathrm{P}_{2} \mathrm{O}_{5}$ contents at $174.45 \mathrm{mbsf}$, a feature that may be related to the presence of apatite and rhodochrosite (Table T3).

The sand layer sampled at 174.0 mbsf shows significantly lower $\mathrm{K}_{2} \mathrm{O}$ and $\mathrm{MgO}$ concentrations than the background composition of the sedimentary pile but has relatively high $\mathrm{Na}_{2} \mathrm{O}$ content (Fig. F11).

\section{Structural geology}

Most of the Site C0012 cores had well-measured structure even though the HPCS produced disturbance in Hole C0012D. Structural measurement data are given in C0012.XLS in STRUCTUR in "Supplementary material." Planar structures such as bedding, faults, shear zones, and veins were reoriented into true geographic coordinates using shipboard paleomagnetic data (see "Structural geology" in the "Methods" chapter [Expedition 333 Scientists, 2012a] for reference).

\section{Holes C0012C and C0012D}

Figure F12 presents the overall distribution of planar structures in Holes C0012C and C0012D. In Holes C0012C and C0012D, bedding shows a wide range of dip angles from $3^{\circ}$ to $70^{\circ}$. Most of the faults and shear zones have high dip angles. The depth profile of structural features in Holes C0012C and C0012D is divided into four zones based on the distribution of bedding dip angles: Zone I (0-14 mbsf), Zone II 
(14-86.5 mbsf), Zone III (86.5-146.5 mbsf), and Zone IV (146.5-180 mbsf).

\section{Bedding}

Planar structures such as green layers, dark brown sand layers, and volcanic ash layers are recognized as bedding. Bedding was measured both on the split core surfaces and using X-ray computed tomography (CT) images. Beds in Zone I are characterized by gentle dip (generally $<30^{\circ}$ ) (Fig. F13), whereas bedding dip angles within Zone II range from $19^{\circ}$ to $70^{\circ}$. In particular, dip angles $>60^{\circ}$ are commonly observed in Zone II. With few exceptions, beds in Zone II strike northeast-southwest and dip southeast (Fig. F14). There are several changes in bed orientation patterns within Zone II. Abrupt changes of bedding orientation are observed at intervals 333-C0012C$6 \mathrm{H}-6,41 \mathrm{~cm}$, and $9 \mathrm{H}-7,80-110 \mathrm{~cm}$. The lowest portion of Zone II (Core 333-C0012C-10H) displays a chaotic occurrence that looks like shallow soft-sediment deformation. In contrast to Zone II, bedding orientations in Zone III follow the same lower dip $\left(<30^{\circ}\right)$ pattern as those of Zone I. In Zone IV, bedding strike and dip are scattered.

\section{Deformation structures}

\section{Faults}

Faults in Holes C0012C and C0012D generally have high dip angles with normal offsets (Figs. F12, F15). They are mostly observed in Zones I and III. Fault planes generally strike northwest-southeast and dip to the northeast or southwest, which suggests conjugate sets formed by northeast-southwest extension (Fig. F16). Although faults are scarce within Zone II, several faults are found slightly above the bottom of Zone II. These faults show a diverse range of strikes and dips. A normal fault in Core 333-C0012C-10H is truncated by bioturbation (Fig. F17), suggesting deformation occurred at very shallow burial depths. At 145 mbsf, which is the transition zone between low-angle bedding (Zone III) and scattered bedding of chaotic deposits (Zone IV), several sets of faults were observed. A normal fault crosscuts two low-angle faults with $4 \mathrm{~mm}$ offsets in interval 333-C0012D5 H-5, 91-96 cm (Fig. F18). Another fault with a moderate dip angle was observed $\sim 1 \mathrm{~cm}$ below those fault sets having northeast-southwest strike and southeast dip direction. Only one reverse fault was observed in Holes C0012C and C0012D (interval 333-C0012D2H-5, 76-82 cm) (Fig. F19).

\section{Chaotic deposits}

In this chapter, the term "chaotic deposit" is used to express intervals where bedding and original sedi- mentary structures were highly disturbed and mixed. Chaotic deposits are developed mainly in three intervals in Holes C0012C and C0012D. All of these intervals are characterized by disrupted beds, folds, and injections of sand or mud.

The first interval occurs at the bottom of Zone I (interval 333-C0012C-2H-5, $53 \mathrm{~cm}$, to $2 \mathrm{H}-\mathrm{CC}, 26 \mathrm{~cm}$; 10.33-14.00 mbsf). The second interval occurs at the bottom of Zone II (interval 333-C0012C-10H-3, 0 $\mathrm{cm}$, to $10 \mathrm{H}-8,121.5 \mathrm{~cm} ; 81.63-86.11 \mathrm{mbsf})$. Within this zone, directions of strikes and dips of bedding are scattered and beds are irregularly truncated by planar structures (Fig. F20). A diapir-shaped dewatering structure (Fig. F21) is also observed here.

Chaotic deposits in the third interval are widely distributed in Zone IV. In this zone, it is difficult to define whether such structures formed naturally or as a result of coring. However, a chaotic deposit in Core 333-C0012D-6H appears to be a natural example rather than coring-induced disturbance because vertically exaggerated structures are not observed here, whereas other disturbed layers are mainly characterized by near-vertical flow structure of mud, indicative of flow-in. Instead of flow structure of mud, poorly sorted muddy sand containing clasts of silt is recognized as fluidized matrix (Fig. F22), suggesting that chaotic deposits resulted from fluidization of the sand layer and disaggregation of silt. The muddy sand matrix shows fining-upward texture at a $\sim 4 \mathrm{~m}$ scale and injects into relatively coherent silt layers. Silt layers are tilted and folded so that they show overall chaotic occurrence. The fluidized muddy sand is also truncated by a later fault (Fig. F22). It is possible that the later fault is related to coring, but the muddy sand injection and layer disruption appear to be natural. The occurrences observed in this core are quite similar to those of slump bodies observed in the Miura and Boso Peninsulas in Japan (Yamamoto et al., 2007). The origin of other chaotic deposits in Zone IV (e.g., Cores 333-C0012D-12H and $13 \mathrm{H})$, whether they are natural or formed due to coring, is still ambiguous.

Chaotic deposits were also described within lithologic Units II and III of Hole C0012A but obscured by severe drilling disturbance (Expedition 322 Scientists, 2010).

\section{Shear zones}

As observed at Site C0011, shear zones with high dip angles that result in large offsets can also be observed at Site C0012 (Fig. F23). Typically, shear zones occur in cores where small faults are also observed but the shear zones show more displacement than the small faults. 


\section{Mineral veins}

Mineral-filled veins were observed between Sections 333-C0012D-11H-4 and 12H-5 (172.6-175.4 mbsf) (Fig. F24). Vein minerals comprise fine-grained calcite with traces of barite. These veins penetrate at a high angle into the silty mud beds of interval 333C0012D-11H-4, 72-99 cm, and presumably extend from a hard sandstone layer immediately below. Except for one southeastward-dipping example, veins strike northeast-southwest and dip steeply northwestward.

\section{Slumping at Site C0012}

The existence of steeply tilted beds developed throughout Zone II and the chaotic interval at the bottom of Zone II suggest that Zone II is a large slump body that was tilted by block rotation, and the chaotic interval corresponds to the basal slip plane of the slump. Hiatuses at the bottom of Zones I and II (see "Paleomagnetism" and "Biostratigraphy"), observed porosity changes (see "Physical properties"), and changes in total sulfur and carbonate concentrations (see "Organic geochemistry") are consistent with the assumed slump. A possible hiatus at the bottom of Zone I (1.07-3.60 Ma) (Fig. F25) implies that the slide event occurred some time between 1.07 and $3.60 \mathrm{Ma}$. On the other hand, the hiatus at the bottom of Zone II (4.49-5.24 Ma) (Fig. F25) also suggests that sediments deposited during this time period were removed by displacement of a basal normal fault. Thickness of the lost sediments is estimated as $14.6-24.5 \mathrm{~m}$ by assuming a sediment deposition rate of $1.94-3.26 \mathrm{~cm} / \mathrm{k} . \mathrm{y}$. (Fig. F25), and removal of this thickness of sediments suggests large displacement along the basal slip zone. The age of the slump base (4.49-5.24 Ma) roughly corresponds to the lithologic Subunit IA/IB boundary at Site C0011, where the number of ash layers and porosity decrease (see "Lithology" and "Physical properties" in the "Site C0011" chapter [Expedition 333 Scientists, 2012b]). This is indicative that the lithologic contrast may play an important role for slumping.

Chaotic intervals in Zone IV and deeper portions (i.e., within lithologic Unit II and at the top of Unit III in Hole C0012A [Expedition 322 Scientists, 2010]) are also regarded as evidence of slumping. Widespread occurrences of slumping may suggest that the Kashinosaki Knoll was continuously uplifted at least from $\sim 9.5 \mathrm{Ma}$ (the age of the chaotic deposit in Unit III) to $\sim 1.1 \mathrm{Ma}$.

\section{Holes C0012E, C0012F, and C0012G}

In Holes C0012E, C0012F, and C0012G, greenish silty claystone with thin sandstone layers and red calcareous claystone overlie basaltic basement (see "Lithology"). Bedding of silty claystone and calcareous claystone are subhorizontal or gently $\left(<30^{\circ}\right)$ dip to northeast (Fig. F26A). Cleavages parallel to bedding are occasionally found within calcareous claystone.

Two sand dikes occur at intervals 333-C0012E-1X-1, $35-38 \mathrm{~cm}$, and $1 \mathrm{X}-2,59-72 \mathrm{~cm}$. The former is relatively thin $(\sim 7 \mathrm{~mm}$ thick) and zigzag shaped (Fig. F27), whereas the latter, branching from an underlying sandstone layer, is thick ( $\sim 5 \mathrm{~cm}$ thick) and intruded the claystone in a straight manner.

Mineral veins with various dipping angles (subhorizontal to subvertical) develop within red calcareous claystone. Although paleomagnetic correction was limited by coring disturbance, several corrected measurements indicate that some of the veins dip southeastward (Fig. F26B). Veins are mainly composed of calcite with accessory barite.

\section{Biostratigraphy}

Preliminary analysis of the core catcher samples from Holes C0012C (Sections 333-C0012C-1H-CC to 14H-CC), C0012D (Sections 333-C0012D-2H-CC to 13H-CC), and C0012E (Sections 333-C0012E-1X-CC to $3 \mathrm{X}-\mathrm{CC})$ reveals assemblages of calcareous nannofossils (Table T4). The biostratigraphic events recognized in Holes C0012C, C0012D, and C0012E are reported in Table T5. All these biostratigraphic events are identified from the analysis of calcareous nannofossils. Accordingly, the sediments drilled in Holes C0012C and C0012D have a Pleistocene to late Miocene age. Hole C0012E sediments deposited on the basaltic basement have a middle Miocene age.

Species abundance is generally common to rare. Sediments throughout the holes contain warm-water genera such as the calcareous nannofossil genus Discoaster.

\section{Calcareous nannofossils}

Preliminary examination of all core catcher samples from Holes C0012C, C0012D, and C0012E obtained well- to poorly preserved nannofossils that occur in common abundance in most of the samples. In the upper part of the sequence, species diversity is comparatively higher and preservation is better. However, severe dissolution occurred in several stratigraphic intervals, leading to coccolith-barren intervals or very poor occurrences (Table T4). Most of the zonal markers of Martini's zonation (1971) and Raffi et al. (2006) have been identified in the sedimentary sequence. The nannofossil occurrences in cores from Holes C0012C, C0012D, and C0012E are listed in Table $\mathbf{T} 4$. 
The youngest assemblages in these holes belong to Pseudoemiliania lacunosa (Zone NN19) and are present in Sample 333-C0012C-1H-CC with Gephyrocapsa parallela (sp. 3). The last consistent occurrence of Reticulofenestra asanoi, which defines the middle part of Zone NN19, is observed between Samples 333-C0012C-1H-CC and 2H-CC. The last occurrence (LO) of Discoaster brouweri is recorded between Samples 333-C0012C-2H-CC and 4H-CC and is poorly constrained because this coincides with an interval of poor nannofossil preservation. The bottom of Zone NN16, marked by the LO of Reticulofenestra pseudoumbilicus, is observed between Samples 333C0012C-4H-CC and 5H-CC. The LO of Amaurolithus spp., which indicates the early Pliocene $(4.5 \mathrm{Ma})$, is found in Samples 333-C0012C-7H-CC and 8H-CC. Discoaster quinqueramus and Discoaster berggrenii, which indicate upper Miocene Zone NN11 (5.59$8.52 \mathrm{Ma}$ ), are found in Samples 333-C0012C-9H-CC to 333-C0012D-12H-CC. The paracme end (Raffi et al., 2006) of $R$. pseudoumbilicus is recorded between Samples 333-C0012C-14H-CC and 333-C0012D-4HCC. The interval of Samples 333-C0012E-1X-CC to $2 \mathrm{X}-\mathrm{CC}$, which is characterized by the occurrence of Cyclicargolithus floridanus, is assigned to the upper part of Zone NN6 (between 12.037 and $13.532 \mathrm{Ma}$ ). The LO of $C$. floridanus in Expedition 333 holes is inferred to occur somewhere in the interval between Samples 333-C0012D-13H-CC (179.997 mbsf) and 333-C0012E-1X-CC (504.205 mbsf). However, because the interval between the base of Hole C0012D (180 mbsf) and the top of Hole C0012E (500 mbsf) was not cored during Expedition 333, we cannot provide more information on the horizon of the LO of C. floridanus. Note that previous nannofossil examination during Expedition 322 reports that the LO of C. floridanus was found between 284.86 and 293.04 mbsf in Hole C0012A (Expedition 322 Scientists, 2010).

\section{Sedimentation rates based on biostratigraphy}

The sedimentation rates in Holes C0012C, C0012D, and C0012E based on calcareous nannofossils are shown and compared with paleomagnetism results in Figure F28. The apparent sedimentation rates are very low $(0.82-1.23 \mathrm{~cm} / \mathrm{k} . \mathrm{y}$.) between 0 and 37.5975 mbsf ( 0 and $3.79 \mathrm{Ma})$. The sedimentation rate increases $(3.87 \mathrm{~cm} / \mathrm{k} . \mathrm{y}$.$) in the interval between$ 37.5975 and 65.0615 mbsf (3.79 and 4.50 Ma). A very low apparent sedimentation rate $(0.83 \mathrm{~cm} / \mathrm{k} . \mathrm{y}$. $)$ is observed in the interval from 65.0615 to 74.065 mbsf (4.5 to $5.59 \mathrm{Ma}$ ). This may suggest the presence of a hiatus near the base of a slumped package inferred from structural observations (primarily bed- ding dips, see "Structural geology") indicating deformation between 14 and $~ 85$ mbsf. The interval from 74.065 to $128.479 \mathrm{mbsf}$ (5.59 to $7.122 \mathrm{Ma}$ ) is characterized by a relatively high sedimentation rate of $3.55 \mathrm{~cm} / \mathrm{k} . \mathrm{y}$. The lowest sample (333-C0012E-2XCC, 510.43 mbsf) shows an age older than 12.037 Ma.

The intervals with very low apparent sedimentation rates may be due to possible time gaps in the upper and middle parts of the sequence during the Pleistocene. Taking into account constraints from paleomagnetism and structural observations, an age gap between Samples 333-C0012C-2H-CC and 3H-CC, corresponding to the top of a slumped package, is suspected. Another age gap is inferred between Samples 333-C0012C-8H-CC and 9H-CC. A possible hiatus associated with a chaotic interval from 81.63 to $86.11 \mathrm{mbsf}$ is also suggested from magnetostratigraphy (see "Paleomagnetism").

\section{Paleomagnetism}

Magnetic susceptibility and remanent magnetization of 258 specimens were measured at Site C0012. Samples were subjected to stepwise alternating-field (AF) demagnetization in order to isolate the characteristic remanent magnetization (ChRM). The samples were demagnetized at 5, 10, 20, and $30 \mathrm{mT}$.

As noted in previous Deep Sea Drilling Project/Ocean Drilling Program/IODP expeditions, drilling-induced magnetization is often pervasive in cored sediments because of the drilling process (e.g., Gee et al., 1989; Zhao et al., 1994). The subsequent magnetization is characterized by natural remanent magnetization (NRM) that is strongly biased toward vertical $\left(\sim 90^{\circ}\right)$ in most specimens. As shown in Figure F29, NRM inclination values are much steeper than inclination values after $30 \mathrm{mT}$ AF demagnetization, indicating that the drilling-induced magnetization had been removed during the 20-30 mT steps.

\section{Holes C0012C and C0012D}

Inclination values at Site C0012 were scattered from $-85^{\circ}$ to $+85^{\circ}$ after $30 \mathrm{mT}$ AF demagnetization, indicating that ChRM directions identified in the specimens may not be original because the inclination values are significantly steeper than expected. Structural data from the site indicating faults, folds, and steeply dipping beds emphasized the need for further investigation into the scatter of the data (see "Structural geology"). Bedding correction performed on the specimens (Fig. F30) showed the corrected inclination data to be more clustered near the expected inclination value $\left( \pm 52^{\circ}\right)$ at this site. Al- 
though the inclination values vary with the correction, the chron and subchron boundaries are not altered by the bedding correction.

\section{Magnetostratigraphy of Holes C0012C and C0012D}

Inclination after $30 \mathrm{mT}$ AF demagnetization illustrates the boundaries between normal and reversed chrons and subchrons, but because of the sampling interval, not every boundary is well defined. As shown in Figure F29 and Table T6, a number of magnetic reversals were determined based on a change in sign of the inclination.

The zone of normal polarity recognized from the top of the hole to Core 333-C0012C-2H was identified as the Brunhes Chron. The Brunhes/Matuyama Chron boundary is located at $\sim 5 \mathrm{mbsf}$, roughly $10 \mathrm{~m}$ higher than at Site C0011. The provisional correlation of tephra chronology (Table T6) indicates a possible equivalent of the Azuki volcanic ash bed (0.85 Ma) in Section 333-C0012C-2H-1 ( 5.8 mbsf) and a probable match to the Pink volcanic ash bed ( 1.05 Ma) in Section 333-C0012C-2H-3 ( 7.0 mbsf), giving an approximation for the Jaramillo Subchron (0.99$1.07 \mathrm{Ma}$ ) (see "Lithology"). However, the Jaramillo Subchron was identifiable with uncertainty from paleomagnetic polarity data, probably due to slow sedimentation during this interval. The estimated sedimentation rate from the two tephra layers is very low $(\sim 0.73 \mathrm{~cm} / \mathrm{k} . \mathrm{y}$.). Therefore, the duration of the Jaramillo Subchron corresponds to only $58 \mathrm{~cm}$, which is too short to identify by our shipboard measurement strategy, although we tentatively assigned $2.59 \mathrm{~m}$ for the Jaramillo. The provisional correlation of tephra chronology also indicates a probable match to the Ohta volcanic ash bed ( 4.0 Ma) in Section 333-C0012C-6H-2, which corresponds to the lower end of the Gilbert Chron. The proximity of the Jaramillo Subchron ( $12 \mathrm{mbsf})$ to the Gilbert Chron ( 18 mbsf) indicates that the lower portion of the Matuyama Chron is missing. A period of normal polarity above the Gilbert Chron has been identified as the Gauss Chron. It is unclear at what age this normal polarity zone begins because of a potential hiatus. This hiatus is also suggested by changes in lithology, bedding dip, porosity, calcium carbonate content, and total sulfur data (see "Lithology," "Structural geology," "Physical properties," and "Organic geochemistry") and represents a gap of roughly $2.5 \mathrm{~m} . y$. (1.07 to $3.6 \mathrm{Ma}$ ). This possible hiatus corresponds to a chaotic interval from interval $333-\mathrm{C} 0012 \mathrm{C}-2 \mathrm{H}-5,53 \mathrm{~cm}$ (10.33 mbsf), to 2H-CC, 26 cm (14.00 mbsf) (see "Structural geology"). The nannofossil Reticulofenestra asanoi, observed in Section 333-C0012C-2H-CC, indicates an age of 0.4360.90 Ma with good coincidence with the Jaramillo Subchron (See "Biostratigraphy"). Cores below 333C0012C-3H show steeply inclined bedding, which is classified as another structural zone (see "Structural geology"). Therefore, we assume that the successive normal chron of the bottom of Cores 333-C0012C$2 \mathrm{H}$ and $3 \mathrm{H}$ corresponds to the Jaramillo Subchron and the Gauss Chron, respectively (Fig. F29). Another chaotic interval from 333-C0012C-10H-3, 0 $\mathrm{cm}(81.63 \mathrm{mbsf})$, to $10 \mathrm{H}-9,121.5 \mathrm{~cm}(86.11 \mathrm{mbsf})$, is also a cause of a possible hiatus (see "Structural geology"). Adopting this possible hiatus, we can explain the fewer occurrences of normal polarity during the Gilbert Chron (Fig. F29).

Comparison of the magnetic susceptibility at Sites C0011 and C0012 as well as correlation of chrons and subchrons was performed in order to identify the missing section of the Matuyama Chron (Fig. F31). Magnetic susceptibility decreases during the upper Gilbert Chron from 3.60 to $4.19 \mathrm{Ma}$ at both Sites C0011 and C0012 (Fig. F31). A gentle curve begins around $5.00 \mathrm{Ma}$ and continues to $7.14 \mathrm{Ma}$, at which point abrupt variations in magnetic susceptibility begin to occur. This coincidence strengthens our interpretation below the hiatus. Consequently, the missing horizon at the hiatus spans most of the lower Matuyama Chron, starting just below the Jaramillo Subchron and continuing into the upper Gauss Chron. The age gap spans $>2$ m.y.

A plot of age versus depth at Site C0012 indicates a hiatus in sedimentation between $\sim 1.0$ and $3.5 \mathrm{Ma}$ at a zone between 10.33 and 14.00 mbsf (Fig. F25). The apparent sedimentation rate shows considerable variation throughout Holes C0012C and C0012D (Fig. F25A). The higher sedimentation rate from 3.5 to $5.0 \mathrm{Ma}$ correlates to an interval of steeply dipping beds (Cores 333-C0012C-3H to 10H, structural Zone II, see "Structural geology"). Assuming an average dip angle of $60^{\circ}$, the true sediment thickness in this interval is reduced by half. The corrected sedimentation rate (Fig. F25B) still shows a higher rate in this interval, but the variation is less drastic.

The most recent sedimentation rate is notably slow $(0.73 \mathrm{~cm} / \mathrm{k} . y$.$) for an input site near a trench, which$ may be a reflection of the topographic height of Site C0012. The sedimentation rate appears to slow between 5.0 and $7.5 \mathrm{Ma}$, after which the sedimentation rate increases once again. Magnetostratigraphic age correlates well with age Model A based on magneto- 
stratigraphy from Expedition 322 (Fig. F25A). Projected age for the Subunit IA/IB, IB/IC, and IC/Unit II boundaries are $4.4,7.2$, and $7.8 \mathrm{Ma}$, respectively.

\section{Holes C0012E, C0012F, and C0012G}

Shipboard paleomagnetic samples from deeper Holes C0012E, C0012F, and C0012G are composed of hemipelagic sediments and basalts. The sediments show normal polarity (Fig. F32); however, we had no additional data to constrain the age at the time of this expedition. Paleomagnetic characterization of basalts is distinctive from that of sediments, which are characterized by higher magnetic susceptibility and paleomagnetic intensity. Drilling-induced remanent magnetization is commonly removed after AF demagnetization at $\sim 5 \mathrm{mT}$ and shows a stable magnetization component decreasing toward the origin. Paleomagnetic inclination shows notably low values near zero (Fig. F32), which implies these basalts erupted at lower latitude south of this site. The limited time of onboard measurement leaves questions on the origin of these basalts.

\section{Physical properties}

The goal of physical properties measurements in Holes C0012C, C0012D, C0012E, C0012F, and C0012G was to provide high-resolution data on bulk physical properties and their downhole variations. All physical properties measurements were made after cores had been imaged by X-ray CT and had equilibrated to room temperature $\left(\sim 20^{\circ} \mathrm{C}\right)$. Wholeround multisensor core logger (MSCL-W) data were collected to define natural gamma radiation, gamma ray attenuation (GRA) density, noncontact resistivity, magnetic susceptibility, and $P$-wave velocity. $P$ wave velocity data from the MSCL-W were of poor quality and will not be discussed. Thermal conductivity was measured using the full-space needle probe method on whole-round cores or the halfspace line source method on working halves of cores. The full-space method was used on samples from Holes C0012C and C0012D, and the half-space method was used on those from Holes C0012E, C0012F, and C0012G because the cores were too hard to allow insertion of the needle probe. Penetrometer, vane shear, and electrical resistivity measurements were made shortly after the core was split, and moisture and density (MAD) analyses were performed on discrete samples collected from either the working halves of split cores or cluster samples taken adjacent to whole-round samples. Discrete resistivity and $P$-wave velocity measurements in the $x-, y$-, and $z$-directions were performed on sample cubes cut from working halves of cores below $500 \mathrm{~m}$ core depth below seafloor (CSF) because the upper sediments were too soft to allow cutting appropriate samples. For basalt samples, modified procedures were used (for details, see "Physical properties" in the "Methods" chapter [Expedition 333 Scientists, 2012a]).

\section{MSCL-W}

GRA density, magnetic susceptibility, electrical resistivity, and natural gamma radiation were measured using the MSCL-W. The results of MSCL-W measurements on cores from Expeditions 322 (Expedition 322 Scientists, 2010) and 333 are summarized with lithologic units (dashed lines) in Figure F33. GRA density, electrical resistivity, and natural gamma radiation all increase slightly with depth, whereas magnetic susceptibility is divided into a zone of gradual decrease with depth and a zone of high variability at the base corresponding to lithologic Unit II. The variation patterns of GRA density, electrical resistivity, magnetic susceptibility, and natural gamma radiation generally show good correlation with lithologic unit boundaries.

\section{GRA density}

GRA density was measured using the MSCL-W based on the detection of a gamma ray beam that is produced by a cesium source (Fig. F33). GRA density remains fairly constant from 7 to $65 \mathrm{~m} \mathrm{CSF}$, consistent with MAD-derived porosities. Subsequently, an increase occurs between 70 and $100 \mathrm{~m} \mathrm{CSF}$, consistent with a decrease in porosity. GRA density dramatically increases again from 140 to 180 m CSF, coinciding with the existence of volcaniclastic sandstones and tuffaceous sandstones (see Lithology columns in Fig. F3). In general, GRA density values are affected by the presence of voids and gaps between the core and core liner, and thus data from Expedition 333 HPCS coring show less scatter than data from Expedition 322 RCB coring.

\section{Magnetic susceptibility}

Magnetic susceptibility gradually decreases downhole within lithologic Unit I, with the exception of an increase between 46 and $76 \mathrm{~m} \mathrm{CSF}$ (Fig. F33). This zone corresponds to ash layers (see Lithology columns in Fig. F3). Spikes of high magnetic susceptibility occur from 140 to $180 \mathrm{~m} \mathrm{CSF}$. These high-value magnetic susceptibility spikes correlate with volcanic material.

\section{Natural gamma radiation}

Natural gamma radiation remains relatively constant between the seafloor and $50 \mathrm{~m}$ CSF (Fig. F33). Then, 
natural gamma radiation sharply decreases and then increases between 55 and $90 \mathrm{~m}$ CSF. Within lithologic Unit II (150 m CSF and below), natural gamma radiation shows large variation.

\section{Electrical resistivity}

Electrical resistivity generally increases with depth (Fig. F33). From the seafloor to $50 \mathrm{~m} \mathrm{CSF}$, a low-resistivity section is observed. Then, resistivity abruptly increases between 50 and $65 \mathrm{~m}$ CSF with a decrease in natural gamma radiation. A small increase occurs between 150 and $178 \mathrm{~m} \mathrm{CSF}$, where volcaniclastic sandstones and tuffaceous sandstones exist.

\section{Moisture and density measurements}

MAD measurements on discrete samples from Site C0012 provide a detailed characterization of bulk density and porosity. All MAD data from Expedition 333 are provided in Table T7, and results from Expeditions 322 (Expedition 322 Scientists, 2010) and 333 are combined in Figure F34. From the surface to $\sim 10$ m CSF, bulk density generally increases and porosity decreases downhole, as expected for progressive burial (Fig. F34). Below 10 m CSF, bulk density slightly decreases and then remains relatively constant to $\sim 70 \mathrm{~m}$ CSF. A sharp increase in bulk density (decrease in porosity) occurs between $\sim 70$ and $100 \mathrm{~m}$ CSF, after which porosity increases between 100 and $130 \mathrm{~m}$ CSF and decreases again between 130 and 170 m CSF. Below 170 m CSF, data show a steady compaction trend, with some scatter in sand-rich units, to the base of the borehole. The sharp porosity decrease between 70 and $100 \mathrm{~m}$ CSF could thus be a transition similar to that observed at Site C0011 below 240 m CSF. Comparison of Site C0011 and C0012 porosity data below the anomalous regions (e.g., below $240 \mathrm{~m} \mathrm{CSF}$ ) indicates that Site C0012 porosity is generally lower than porosity from similar depths at Site C0011 (Fig. F35). A possible explanation for the lower porosity at Site C0012 is removal of overlying material by erosion or slope failure. This interpretation would be consistent with the observed time gap of $\sim 2 \mathrm{~m} . \mathrm{y}$. found at $\sim 10 \mathrm{mbsf}$ (see "Paleomagnetism").

Within the basalt, measured porosity varies from 0.09 to 0.37 and bulk density varies from 2.15 to $2.64 \mathrm{~g} / \mathrm{cm}^{3}$. Directly below the sediment/basalt interface, values are scattered and then generally decrease to $\sim 590 \mathrm{~m} \mathrm{CSF}$, below which they generally increase. Measured grain density varies from 2.75 to $2.95 \mathrm{~g} / \mathrm{cm}^{3}$.

\section{Strength measurements}

Strength in soft sediments was measured using an analog vane shear device (Wykeham Farrance, model
WF23544) and a pocket penetrometer (Geotest E284B) in the working half of the core from 0 to 145 $\mathrm{m}$ CSF. Beneath this depth, high sediment strength did not allow measurements with these devices. Strength globally increases with depth and decreasing porosity (Fig. F36). In spite of scattering, the strength data present boundaries that are consistent with those of other physical properties. Shear strength progressively increases from 0 to $70-80 \mathrm{~m}$ CSF. Shear strength rapidly increases from 60 to 100 $\mathrm{m}$ CSF and then remains stable to $140 \mathrm{~m} \mathrm{CSF}$. At 140 $m$ CSF, the shear strength suddenly increases again by $50 \mathrm{kPa}$, and measurement had to be stopped at $\sim 150 \mathrm{~m}$ CSF because sediments were too strong.

\section{$P$-wave velocity}

$P$-wave velocity was measured on discrete cubes cut from working halves of cores below $500 \mathrm{~m}$ CSF. Velocities were measured in the $x_{-}, y$, and $z$-directions, and horizontal- and vertical-plane anisotropies were calculated (see "Physical properties" in the "Methods" chapter [Expedition 333 Scientists, 2012a]). In red clay above the sediment/basement boundary $(\sim 525 \mathrm{~m} \mathrm{CSF}), P$-wave velocity in the $z$-direction (Fig. F37A; Table T8) is nearly constant at $\sim 2000 \mathrm{~m} / \mathrm{s}$. In the basement, $P$-wave velocity generally increases with depth from $\sim 3000$ to $\sim 5000 \mathrm{~m} / \mathrm{s}$.

Vertical-plane anisotropy decreases from $\sim 15 \%$ to $0 \%$ over the red clay (Fig. F37B), indicating that $P$-wave velocity in the $z$-direction is less than in either of the horizontal directions. This is consistent with a transversely isotropic medium in which bedding planes are roughly horizontal. Within the basement, anisotropy remains at or near $0 \%$, indicating a more isotropic medium.

\section{Electrical resistivity}

Resistivity measurements were made with a four-pin, $2 \mathrm{kHz}$ Wenner array. Resistivity values for samples from Site C0012 are given in Table T9. The measured values agree with the baseline values measured by the MSCL-W. Partial desiccation of the core occurred from 55 to $62 \mathrm{~m} \mathrm{CSF}$; these values are not plotted and have been removed from Table T9. Resistivity generally follows the trend of porosity values, indicating that the formation resistivity is a response to changes in pore volume (Fig. F38). Values are nearly constant from 12 to $78 \mathrm{~m} \mathrm{CSF}$, reflecting the trend of nearly constant porosity over this interval. At $78 \mathrm{~m}$ CSF, resistivity begins increasing with depth and follows the trend of porosity to the base of the cored interval.

The relationship between porosity and resistivity can be illustrated with a log-log plot of porosity and re- 
sistivity (Ellis and Singer, 2007) (Fig. F39); resistivity was matched with nearest neighbor porosity values (within $30 \mathrm{~cm}$ ) from MAD measurements. The data from the zone of anomalously high porosity between 12 and $78 \mathrm{~m}$ CSF plot below the trend defined by the rest of the data. This could be due to the presence of a cementing phase (Ellis and Singer, 2007) or a change in clay mineralogy (Henry, 1997).

Electrical resistivity was measured on discrete cubes cut from working halves of cores below $500 \mathrm{~m} \mathrm{CSF}$. Measurements were performed in the $x-, y$-, and $z$-directions, allowing computation of horizontal and vertical anisotropies (see "Physical properties" in the "Methods" chapter [Expedition 333 Scientists, 2012a]). Resistivity in the $z$-direction increases with depth from 3.3 to $27 \Omega \mathrm{m}$ (Fig. F40A; Table T10). There is a cluster of elevated resistivity values near the sediment/basement interface. Error may be large for high-resistivity samples, such as from the basalt, because the measured value may be affected by the amount of water applied to the sample surface. The observation that the $x$-direction is consistently greater than the $y$-direction (Table T10) would be consistent with some type of measurement error. Vertical-plane anisotropy is constant at about $-50 \%$ in the red clay above the basement (Fig. F40B). Higher resistivity in the $z$-direction in the sediments is consistent with a transversely isotropic medium in which the bedding planes are approximately horizontal.

\section{Thermal conductivity and heat flow}

Thermal conductivity data obtained on whole-round core measurements using a needle probe sensor in Holes C0012C and C0012D are shown together as function of depth (Fig. F41). The trend of thermal conductivity with depth in Holes C0012C and C0012D is correlated very well with those of other physical properties, for example, resistivity and bulk density (MAD). This observation suggests that porosity is the major controlling factor for those different physical properties, which include thermal conductivity at this site.

Thermal gradient values are evaluated from measurements using the advanced piston corer temperature tool (APCT-3) taken at 10 depths in Holes C0012C and C0012D together (Fig. F42). The mean thermal gradient value determined is $135^{\circ} \mathrm{C} / \mathrm{km}$. The mean seafloor temperature, or the intercept temperature at the seafloor on the plot, is $2.85^{\circ} \mathrm{C}$, which is slightly higher than the measured mudline temperatures observed during the 10 temperature measurements using the APCT-3.
Heat flow is defined as the product of thermal gradient $(d T / d z)$ and corresponding mean thermal conductivity $\left(k_{\text {mean }}\right)$ of the depth interval where temperature gradient is measured. Thus, heat flow in Holes C0012C and C0012D is estimated using the results from the two holes. The estimated heat flow value at this site is $141 \mathrm{~mW} / \mathrm{m}^{2}$, amounting to $\sim 1.5$ times as high as that of $89.5 \mathrm{~mW} / \mathrm{m}^{2}$ determined for Hole C0011C. Based on the determined heat flow value of $141 \mathrm{~mW} / \mathrm{m}^{2}$ as well as the thermal conductivity values that we obtained onboard by core measurements and data from Expedition 322 (Expedition 322 Scientists, 2010), a temperature profile to the bottom of this hole was synthesized and is shown in Figure F43. Temperature extrapolated to the top of basement (at $526 \mathrm{~m} \mathrm{CSF}$ ) is estimated to be $\sim 64^{\circ} \mathrm{C}$.

Measurements of thermal conductivity of the core samples taken for depths $>500 \mathrm{~m}$ CSF were also made, and data are shown in Figure F44.

\section{Inorganic geochemistry}

The main objective of the inorganic geochemistry program at this site was to document the geochemical properties of subduction inputs at a site located at a basement high, near the crest of the Kashinosaki Knoll. Such data will increase our understanding of how basement topography and concomitant changes in temperature regime and stratigraphy may control fluid composition, flow, and water-rock interactions in the presubduction equivalent of the seismogenic zone. A total of 29 interstitial water samples were squeezed from selected whole-round sections for chemical and isotopic analyses. Sample depths ranged from 0 to $\sim 525$ mbsf. One sample per core was collected when possible; however, samples were collected at a higher spatial resolution in the uppermost $10 \mathrm{~m}$ in order to potentially help define the sulfate-methane transition. Additionally, two samples were collected from the red claystone in Core 333-C0012E-3X.

\section{Fluid recovery}

To obtain enough interstitial water for shipboard and shore-based analyses, $19-31 \mathrm{~cm}$ long wholeround sections were squeezed from Holes C0012C and $\mathrm{C} 0012 \mathrm{D}$. In the red claystone located directly above the basement in Holes C0012E and C0012G, 49-61 cm long whole-round sections were squeezed. Interstitial water volumes normalized by section length $(\mathrm{mL} / \mathrm{cm})$ recovered from whole-round sections by squeezing at a maximum pressure of 2500 pounds per square inch (17.2 MPa) are presented as a 
function of depth in Figure F45A. Interstitial water volumes per length of interstitial water section show a decrease with depth from 2.75 to $0.71 \mathrm{~mL} / \mathrm{cm}$ in the upper $\sim 180 \mathrm{~m}$ of Holes C0012C and C0012D. In the deeper material above the basement, volumes were significantly lower, ranging from 0.08 to 0.22 $\mathrm{mL} / \mathrm{cm}$.

The strata here are slightly to moderately lithified; however, the core quality, particularly for core obtained via the HPCS, was good. Therefore, we expect contamination by drilling fluid at this site to be minimal. The dissolved sulfate profile (Fig. F45B) shows quite a bit of structure. The observed distribution precludes any correction for potential contamination, which is consistent with the findings of Expedition 322 (Expedition 322 Scientists, 2010). The uncorrected interstitial water data collected at Site C0012 are listed in Table T11 and illustrated in Figures F46, F47, and F48.

\section{Salinity, chlorinity, and sodium}

Interstitial water salinity in Holes C0012C and C0012D increases slightly from 35.72 at $\sim 0.6$ mbsf to 36.33 at $\sim 47$ mbsf then decreases with depth to 33.56 at 180 mbsf. The salinity profile shows good continuity with that of Hole C0012A drilled during Expedition 322. Chlorinity in Holes C0012C and C0012D decreases from $549 \mathrm{mM}$ at the surface to $566 \mathrm{mM}$ at $47 \mathrm{mbsf}$, which is followed by a slight decrease to $557 \mathrm{mM}$ at 180 mbsf. The data from Expedition 322 indicate an increasing trend in chlorinity below this depth. This is consistent with what is observed in Holes C0012E and C0012G near the sediment/basalt interface where $\mathrm{Cl}$ values are high, ranging from 600 to $640 \mathrm{mM}$. The trend of increasing $\mathrm{Cl}$ is likely caused by hydration reactions during alteration of volcanic ash, volcanic sand, and basaltic basement, as suggested by Expedition 322 Scientists (2010).

Sodium remains relatively constant at $\sim 470 \mathrm{mM}$ from the surface to 180 mbsf in Holes C0012C and C0012D. This is consistent with the observed $\mathrm{Na}$ profile in Hole C0012A. Sodium in Holes C0012E and $\mathrm{C} 0012 \mathrm{G}$ is low, ranging from 260 to $300 \mathrm{mM}$. The decrease in dissolved $\mathrm{Na}$ in the lower sections may be a result of carbonate formation or the formation of zeolites from the alteration of volcanic glass.

\section{Biogeochemical processes}

\section{Sulfate and alkalinity}

Sulfate in Holes C0012C and C0012D slightly decreases from $28.6 \mathrm{mM}$ at the surface to $26.3 \mathrm{mM}$ at 74 mbsf. The dissolved sulfate profile below $74 \mathrm{mbsf}$ indicates continued depletion with depth, which is consistent with the observations of Expedition 322. The relatively constant sulfate profile from the surface to 74 mbsf exhibits $\mathrm{SO}_{4}$ concentration similar to modern seawater. Below $74 \mathrm{mbsf}$, sulfate decreases downward, almost linearly with slight curvature, suggesting most sulfate reduction occurs below the depths cored during Expedition 333 and therefore that the sulfate reduction zone must lie much deeper than at Site C0011, where it is observed around 80 mbsf. The sulfate reduction zone at Site C0011 is, itself, relatively deep compared to other sites along the Kumano transect (Tobin et al., 2009), including IODP Site C0018, where the sulfate reduction zone is found within the upper 15-20 mbsf. During Expedition 322 it was observed that maximum sulfate depletion, which occurs at $\sim 300$ mbsf, coincided with a marked increase in methane concentration (Expedition 322 Scientists, 2010). They interpreted the sulfate profile at Site C0012 as being driven by anaerobic methane oxidation. The deep sulfate reduction zone at Site C0012 may be attributed to the bathymetric high on which Site C0012 sits, leading to slower average sedimentation rates, particularly over the last 3 m.y. (see "Paleomagnetism"), and lower average organic matter content than at Site C0011. Additionally, in Holes C0012E and C0012G and the deepest sections of Hole C0012A, sulfate concentration increases slowly in the interval below $\sim 450$ mbsf, which may indicate diffusional exchange with fluids from the basalt basement.

Alkalinity in Holes C0012C and C0012D increases with depth from $2.9 \mathrm{mM}$ near the surface to $4.0 \mathrm{mM}$ at $47 \mathrm{mbsf}$ and then decreases to $1.8 \mathrm{mM}$ at 106 mbsf. Below 106 mbsf, alkalinity increases again with depth to $2.6 \mathrm{mM}$ at $138 \mathrm{mbsf}$ and then decreases to $0.7 \mathrm{mM}$ at $180 \mathrm{mbsf}$. In Holes C0012E and C0012G, alkalinity is $<1 \mathrm{mM}$, which is consistent with Hole C0012A (Fig. F46).

\section{Ammonium, phosphate, and bromide}

Ammonium in Holes C0012C and C0012D increases with depth from $0 \mathrm{mM}$ at the surface to $0.58 \mathrm{mM}$ at 120 mbsf and then stays almost constant at $\sim 0.6 \mathrm{mM}$ between 120 and 170 mbsf. Ammonium increases again with depth from $0.62 \mathrm{mM}$ at $170 \mathrm{mbsf}$ to 0.72 $\mathrm{mM}$ at 180 mbsf. Ammonium throughout Holes C0012C and C0012D and into Holes C0012A, C0012E, and C0012G is quite low $(<1 \mathrm{mM})$.

Phosphate in Holes C0012C and C0012D gradually decreases with depth from $4.4 \mu \mathrm{M}$ near the surface to $0.5 \mu \mathrm{M}$ at $\sim 120$ mbsf. Below $\sim 170 \mathrm{mbsf}$, dissolved phosphate is not detected. Bromide increases monotonically throughout Holes C0012C and C0012D. 
This trend continues throughout the sediment drilled in Holes C0012E/C0012G and C0012A to the sediment/basalt interface.

\section{Major cations ( $\mathrm{Ca}, \mathrm{Mg}$, and $\mathrm{K}$ )}

Calcium increases with depth throughout Holes C0012C and C0012D from $11 \mathrm{mM}$ at $\sim 0$ mbsf to 43 $\mathrm{mM}$ at 180 mbsf. The rate of increase changes abruptly at $\sim 70 \mathrm{mbsf}$. This trend is consistent with the observed data from Hole C0012A. The deeper sediment of Holes C0012E and C0012G has notably higher $\mathrm{Ca}(177-207 \mathrm{mM}$ at 502-524 mbsf), which is also consistent with the Hole C0012A data. The Ca trend observed at Site C0012 is consistent with carbonate precipitation even at very low alkalinity $(<2$ $\mathrm{mM}$ ). Carbonate was recovered from veins in sandstones at $\sim 170 \mathrm{mbsf}$ and the red claystone directly above the basement.

Magnesium in Holes C0012C and C0012D decreases with depth from $52 \mathrm{mM}$ at the surface to $7.9 \mathrm{mM}$ at 180 mbsf. The rate of the decrease becomes higher at $\sim 70$ mbsf. The $\mathrm{Mg}$ trend is well correlated with that found during Expedition 322 and continues to Holes C0012E and C0012G, with low $\mathrm{Mg}$ values $(<10 \mathrm{mM})$.

Potassium in Holes C0012C and C0012D generally decreases with depth from $11.5 \mathrm{mM}$ at $\sim 0$ mbsf to $2.4 \mathrm{mM}$ at 180 mbsf. The rate of change in the $\mathrm{K}$ decrease becomes higher at $\sim 70 \mathrm{mbsf}$. This is consistent with the trend from Hole C0012A, which continues to Holes C0012E and C0012G. Decreasing Mg and K in the upper 200 mbsf may be interpreted as $\mathrm{Mg}$ and $\mathrm{K}$ uptake by clay formation (i.e., smectite) during volcanic ash alteration.

\section{Minor elements ( $\mathrm{B}, \mathrm{Li}, \mathrm{Si}, \mathrm{Sr}, \mathrm{Ba}, \mathrm{Mn}$, and $\mathrm{Fe}$ )}

Boron in Holes C0012C and C0012D decreases with depth from $462 \mu \mathrm{M}$ at $\sim 0$ mbsf to $380 \mu \mathrm{M}$ at $64 \mathrm{mbsf}$ and then abruptly decreases to $287 \mu \mathrm{M}$ at $74 \mathrm{mbsf}$. Below 74 mbsf, B is discontinuous. The average B in Hole C0012D $(317 \pm 60 \mu \mathrm{M})$ is consistent with the observations of Hole C0012A. The B data in Holes C0012E and C0012G are well correlated.

Lithium in Holes C0012C and C0012D generally increases with depth from $2.3 \mu \mathrm{M}$ near the surface to $215 \mu \mathrm{M}$ at $\sim 150 \mathrm{mbsf}$ and then remains relatively constant from 150 to $180 \mathrm{mbsf}$. In the interval from 74 to $92 \mathrm{mbsf}$, the rate of Li increase is quite high (3 $\mu \mathrm{M} / \mathrm{m})$. The Li profile of Holes C0012C and C0012D is slightly offset from that of Hole C0012A, particularly below $60 \mathrm{mbsf}$ and below $500 \mathrm{mbsf}$ (Fig. F47).

Dissolved silica is generally higher than $\mathrm{Si}$ in modern seawater $(160 \mu \mathrm{M})$ and exhibits a rapid increase from $\sim 460 \mu \mathrm{M}$ at the seafloor to $\sim 840 \mu \mathrm{M}$ at 64 mbsf. This is followed by a significant decrease to $\sim 290 \mu \mathrm{M}$ at $\sim 91$ mbsf, below which it is fairly scattered. This trend is consistent with the observed profile of dissolved Si in Hole C0012A, which displays a step at 200 mbsf, where Si concentration further drops to values around $100 \mu \mathrm{M}$ near the base of the hole. The deeper Holes C0012E and C0012G fall along the trend of slightly increasing Si below 400 mbsf, which was observed in Hole C0012A. The distinct decrease in $\mathrm{Si}$ at $91 \mathrm{mbsf}$ is consistent with a sharp decrease in porosity, which is observed between $\sim 70$ and 100 mbsf (see "Physical properties"). In conjunction with the findings of Expedition 322, we interpret the distribution of $\mathrm{Si}$, as well as $\mathrm{Mg}$ and $\mathrm{K}$, below $\sim 100$ mbsf as being controlled by the formation of montmorillonite phases during the alteration of volcanic glass (Expedition 322 Scientists, 2010).

Strontium in Holes C0012C and C0012D increases from $87 \mu \mathrm{M}$ at $\sim 0$ mbsf to $190 \mu \mathrm{M}$ at 180 mbsf. The rate of $\mathrm{Sr}$ increase downhole changes at $\sim 80 \mathrm{mbsf}$ from 0.2 to $0.75 \mu \mathrm{M} / \mathrm{m}$. The $\mathrm{Sr}$ profile correlates relatively well with that observed in Hole C0012A. The increase in $\mathrm{Sr}$ with depth is likely related to the reaction of volcaniclastic material. Sr in Holes C0012E and C0012G is distinctly high $(360-420 \mu \mathrm{M}$ at $502-$ $524 \mathrm{mbsf}$ ) and may be related to the alteration of basalt.

Barium in Holes C0012C and C0012D generally increases from $0.5 \mu \mathrm{M}$ near the surface to $2.1 \mu \mathrm{M}$ at 180 mbsf. The rate of $\mathrm{Ba}$ increase changes at $\sim 90$ mbsf from 3 to $16 \mathrm{nM} / \mathrm{m}$. The trend in Ba concentration is continued to Hole C0012A, and trends at the base of Hole C0012 continue into Holes C0012E and C0012G.

Manganese in Holes C0012C and C0012D increases from $7.2 \mu \mathrm{M}$ at $\sim 0$ mbsf to $120 \mu \mathrm{M}$ at $160 \mathrm{mbsf}$ and then rapidly decreases to $46 \mu \mathrm{M}$ at 180 mbsf. The pattern of rapid decrease is consistent with $\mathrm{Mn}$ in Hole C0012A. Mn in Holes C0012E and C0012G is relatively low (10-36 $\mu \mathrm{M}$ at 502-524 mbsf) and consistent with that of Hole C0012A.

Iron in Holes C0012C and C0012D, though displaying some scatter in the data, broadly decreases with depth from a maximum of $\sim 15 \mu \mathrm{M}$ at 9 mbsf to $<1$ $\mu \mathrm{M}$ at $\sim 100$ mbsf. The trend of low Fe concentration continues into Hole C0012A. Below 200 mbsf, Fe is generally not detected, which is also the case in Hole C0012A, and any Fe that is detected is $<1 \mu \mathrm{M}$.

\section{Trace elements ( $\mathrm{Rb}, \mathrm{Cs}, \mathrm{V}, \mathrm{Cu}, \mathrm{Zn}, \mathrm{Mo}, \mathrm{Pb}$, and $U$ )}

Rubidium decreases with depth from $\sim 1770 \mathrm{nM}$ near the surface to $180 \mathrm{nM}$ at $180 \mathrm{mbsf}$ in Holes C0012C and C0012D. In Holes C0012E and C0012G, Rb is 
slightly lower ( 100-130 nM). Rb is consistent with Hole C0012A from Expedition 322 (Fig. F48).

Cesium decreases with depth from $4.8 \mathrm{nM}$ at $\sim 0$ mbsf to $1.5 \mathrm{nM}$ at $47 \mathrm{mbsf}$ in Holes C0012C and C0012D and then abruptly increases to $\sim 2 \mathrm{nM}$ at $\sim 70$ mbsf. Then, Cs increases from $1.3 \mathrm{nM}$ at 92 mbsf to $2.1 \mathrm{nM}$ at $180 \mathrm{mbsf}$ with little fluctuation. Cs in Holes C0012E and C0012G is relatively low (1.1-2.0 $\mathrm{nM}$ at 502-524 mbsf). These values correspond well to the observed Cs in Hole C0012A.

Vanadium ranges from 25 to $46 \mathrm{nM}$ in the upper 30 mbsf. V slightly increases with depth from $28 \mathrm{nM}$ at 35 mbsf to $30 \mathrm{nM}$ at 74 mbsf. Below $92 \mathrm{mbsf}$, V remains relatively constant at $\sim 25 \mathrm{nM}$. $\mathrm{V}$ in Holes C0012C and C0012D is $15 \mathrm{nM}$ higher than in Hole C0012A in the overlapping interval from 90 to 180 mbsf. In Hole C0012E, $\mathrm{V}$ ranges from 28 to $38 \mathrm{nM}$ in the interval from 502 to 524 mbsf. In Hole C0012A, a broader range of $\mathrm{V}$ was observed; $\mathrm{V}$ concentration in C0012E and C0012G falls within this range.

Copper is on average $2300 \pm 210 \mathrm{nM}$ in the upper $17 \mathrm{~m}$ of Hole C0012C. In the interval from 28 to 180 mbsf, $\mathrm{Cu}$ ranges from 500 to $7600 \mathrm{nM}$. In the red claystone of Holes C0012E and C0012G, Cu is relatively low, ranging from 560 to $1600 \mathrm{nM}$.

Zinc ranges from 500 to $1500 \mathrm{nM}$ in the upper $150 \mathrm{~m}$ of Holes C0012C and C0012D. Below $150 \mathrm{mbsf}, \mathrm{Zn}$ is generally $<500 \mathrm{nM}$. In Holes C0012E and C0012G, $\mathrm{Zn}$ exhibits a large range with concentration from 300 to $1400 \mathrm{nM}$ in the interval from 502 to 524 mbsf. Large variation is also observed within the data from Expedition 322.

Molybdenum in Holes C0012C and C0012D slightly decreases with depth from $134 \mathrm{nM}$ at the surface to $93 \mathrm{nM}$ at 64 mbsf and then increases to $\sim 300 \mathrm{nM}$ at 180 mbsf. This is consistent with Mo from Hole C0012A. Mo in Holes C0012E and C0012G ranges from 270 to $360 \mathrm{nM}$, which is consistent with Hole C0012A.

Lead in Holes C0012C and C0012D ranges from 2.7 to $3.6 \mathrm{nM}$ in the upper $9 \mathrm{mbsf}$ with a broad decrease with depth to $0.7 \mathrm{nM}$ at 64 mbsf. Below $91 \mathrm{mbsf}, \mathrm{Pb}$ generally increases to $2.7 \mathrm{nM}$ at $130 \mathrm{mbsf}$, followed by a decrease to $0.6 \mathrm{nM}$ at $180 \mathrm{mbsf}$. In Hole C0012A, $\mathrm{Pb}$ is relatively constant with average $\mathrm{Pb}$ values of $10 \pm 0.37 \mathrm{nM}$. The $\mathrm{Pb}$ values of the red claystone in Holes C0012E and C0012G are consistent with this value.

Uranium decreases with depth from $5.9 \mathrm{nM}$ near the surface to $\sim 2.4 \mathrm{nM}$ at $\sim 50 \mathrm{mbsf}$. U remains relatively consistent at $\sim 2.4 \mathrm{nM}$ in the interval from 50 to 130 mbsf and then decreases with depth to $0.4 \mathrm{nM}$ at 180 mbsf. This trend is broadly consistent with the data from Expedition 322, as is the U within the deep sediment in Holes C0012E and C0012G.

\section{Organic geochemistry Hydrocarbon gas}

At Site C0012, methane and ethane are either below detection or present at low concentrations. No heavier hydrocarbon gases (C3 and C4) were found (Table T12; Fig. F49). Hydrocarbon gases are absent in the upper 177 mbsf (Holes C0012C and C0012D), with one exception at $174.1 \mathrm{mbsf}$, where methane appears at 2.5 parts per million by volume (ppmv). In the sediments between 501.4 and $520.4 \mathrm{mbsf}$ (Hole C0012E), methane occurs at low concentrations, varying from 23.3 to $119.7 \mathrm{ppmv}$, and ethane was only sporadically detected, ranging between 0 and 1.9 ppmv. In the two horizons where both methane and ethane were detected, $\mathrm{C} 1 / \mathrm{C} 2$ ratios are $<100$, possibly indicating the organic matter is mature and the hydrocarbon gases are thermogenic.

\section{Sediment carbon, nitrogen, and sulfur composition}

Calcium carbonate $\left(\mathrm{CaCO}_{3}\right)$ concentration (Table T13; Fig. F50) ranges between 0.21 and $45.06 \mathrm{wt} \%$ with an average of $6.08 \mathrm{wt} \%$. The variations of $\mathrm{CaCO}_{3}$ content defines the following five stages:

1. Upper $\sim 11$ mbsf: the values are relatively high, varying between 6.58 and $16.45 \mathrm{wt} \%$.

2. Approximately 11-52 mbsf: the concentration remains low and displays little variation, ranging between 0.29 and $4.52 \mathrm{wt} \%$.

3. Approximately 61-137 mbsf: $\mathrm{CaCO}_{3}$ content is scattered, fluctuating in a wide range of 0.55$18.20 \mathrm{wt} \%$, but exhibits an overall positive excursion.

4. Approximately $137-180$ mbsf: the amounts of $\mathrm{CaCO}_{3}$ are low and uniform (mostly $<2.5 \mathrm{wt} \%$ ) in most cores and show several elevated values at the bottom of the Hole C0012D.

5. Approximately $500-525$ mbsf: high $\mathrm{CaCO}_{3}$ concentration varies between 7.02 and $45.06 \mathrm{wt} \%$.

Notably, the Stage $1 / 2$ boundary is roughly consistent with the top of a slump (see "Structural geology"), where the stratigraphic record also presents a hiatus (see "Paleomagnetism" and "Biostratigraphy"). The high $\mathrm{CaCO}_{3}$ values in Stages 1 and 3 are consistent with the abundance of nannofossils observed by smear slides in the sediments in the upper $\sim 8$ mbsf, between $\sim 68$ and $\sim 79 \mathrm{mbsf}$, and at $\sim 108$ mbsf (see Site C0012 smear slides in "Core descriptions"). 
Total organic carbon (TOC), total nitrogen (TN), and total sulfur (TS) concentrations are low at Site C0012, ranging between 0.03 and $0.52 \mathrm{wt} \%, 0.02$ and $0.07 \mathrm{wt} \%$, and 0 and $0.49 \mathrm{wt} \%$, respectively (Table T13; Fig. F50). The atomic ratios of TOC to TN $\left(\mathrm{TOC} / \mathrm{TN}_{\mathrm{at}}\right)$ fall in the range of 1.3-10.6, suggesting a marine origin of the organic matter. The variations of these four parameters share an overall similar pattern, including scattered but progressively increasing values in the upper $\sim 52$ mbsf, relatively uniform values between $\sim 52$ and $\sim 180$ mbsf, and relatively low values between $\sim 500$ and 525 mbsf. A distinct increase in TS content is also observed at $\sim 10 \mathrm{mbsf}$, which corresponds to the time gap observed in the paleomagnetic analyses (see "Paleomagnetism").

\section{Rock-Eval pyrolysis}

We selected 23 samples for Rock-Eval analyses (Table T14; Fig. F51). The amounts of hydrocarbon already present in the samples (S1) and hydrocarbon generated by pyrolytic degradation (S2) are low, with S1 ranging between 0 and $0.02 \mathrm{mg}$ hydrocarbon/g sediment (mg HC/g sediment) and S2 between 0.04 and $0.35 \mathrm{mg} \mathrm{HC} / \mathrm{g}$ sediment. Samples in the upper $\sim 10$ mbsf and below $\sim 80$ mbsf have $T_{\max }$ values $<430^{\circ} \mathrm{C}$, suggesting the organic matter is thermally immature. High $T_{\max }$ values $\left(604^{\circ}-607^{\circ} \mathrm{C}\right)$ of the sediments between $\sim 20$ and $\sim 80$ mbsf are indicative of thermally overmature organic matter, perhaps suggesting the organic matter at this depth interval was transported from a region where thermal gradients have been sufficiently high to mature the organic matter. The low production index values in all the cores (ranging from 0.01 to 0.18 ) reflect either immaturity of the organic matter for the sediments in the upper $10 \mathrm{mbsf}$ and below 80 mbsf or overmaturity of the organic matter for the sediments between $\sim 20$ and 80 mbsf. Hydrogen index values vary between 15 and $86 \mathrm{mg}$ $\mathrm{HC} / \mathrm{g}$ TOC and hence fall in the range for terrigenous organic matter (Tissot and Welte, 1984). This source characterization is inconsistent with the low $\mathrm{TOC} / \mathrm{TN}_{\mathrm{at}}$ ratios, which suggests that organic matter is mainly derived from marine sources. It is important to note that TOC concentration at Site C0012 is $<0.5 \mathrm{wt} \%$, which could affect the reliability of the Rock-Eval parameters (Espitalié et al., 1984). The interpretations herein about the thermal maturity and sources of the organic matter remain to be verified by further shore-based analyses.

\section{Igneous petrology}

During Expedition 333, basement rocks were recovered in Holes C0012E, C0012F, and C0012G.

\section{Hole C0012E}

The sediment/basement boundary was recovered at 525.815 mbsf (Section 333-C0012E-3X-7, $114 \mathrm{~cm}$ ). In total, $1.53 \mathrm{~m}$ pillow lavas were cored in this hole with a recovery rate of $100 \%$.

\section{Hole C0012F}

The sediment/basement boundary was recovered at 520.46 mbsf (Section 333-C0012F-1R-1, 46 cm). In total, $3.45 \mathrm{~m}$ igneous rocks were cored with a recovery rate of $\sim 68 \%$. All the igneous rocks recovered in this hole are classified as pillow lavas.

\section{Hole C0012G}

The sediment/basement boundary was recovered at 525.69 mbsf (Section 333-C0012G-2R-2, $80 \mathrm{~cm}$ ). In total, $100.75 \mathrm{~m}$ basement rocks were cored in this hole with a recovery rate of $\sim 20 \%$. The $100.75 \mathrm{~m}$ igneous section was divided into two igneous units: pillow lavas (Unit I) and sheet flows with pillow lava interlayers (Unit II) (Fig. F52).

Pillow lavas of Unit I (Sections 333-C0012G-2R-2, 80 $\mathrm{cm}$, to $6 \mathrm{R}-1,22 \mathrm{~cm}$ ) are composed of pillow basalts. The pillows are predominantly phyric, and grain size ranges from glassy at the chilled margins to cryptocrystalline or microcrystalline. The groundmass of pillow basalts generally consists of plagioclase and clinopyroxene microlites, with interstitial titanomagnetite and altered glass. Phenocrysts in these rocks are mainly plagioclase, clinopyroxene, and olivine, in order of decreasing abundance, commonly clustered in a glomeroporphyritic texture. Pillow basalts were moderately to heavily altered. The dominant alteration product is saponite. Celadonite and analcime occur as void fillings. Other zeolites and pyrite occur as minor components. This assemblage indicates a reducing low temperature alteration environment.

Unit II sheet flows with pillow lava interlayers (Sections 333-C0012G-6R-1, $22 \mathrm{~cm}$, to 15R-CC, bottom) are dominantly composed of sheet flows. Pillow lavas occurred as interlayers (Fig. F52), indicating a greater prevalence of massive flows deeper in the section. The individual cooling units of sheet flows range from tens of centimeters to several meters thick. Individual flows are commonly separated by chilled margins. Where contacts were not recovered, individual flows were distinguished by systematic changes in grain size. The sheet flows have more or less the same petrology as pillow basalts but show interstitial texture and are generally less vesicular. Thin section observations show that the most finely grained rocks have intergranular to interstitial 
groundmass textures. In this unit, Fe oxyhydroxide is found as alteration products in veins and alteration halos. Celadonite and saponite and, locally, pyrite are present in the rock mass. This indicates that alteration in Unit II occurred both under iron oxidizing conditions and iron reducing conditions. These most probably occurred at different times but the sequence of events is not yet known.

\section{Visual core descriptions and thin sections}

Digital images and visual core descriptions as well as thin section descriptions are included in "Core descriptions."

\section{References}

Ellis, D.V., and Singer, J.M., 2007. Well Logging for Earth Scientists, (2nd ed.): Dordrecht, The Netherlands (Springer).

Espitalié, J., Senga Makadi, K., and Trichet, J., 1984. Role of the mineral matrix during kerogen pyrolysis. Org. Geochem., 6:365-382. doi:10.1016/0146-6380(84)90059-7

Expedition 322 Scientists, 2010. Site C0012. In Saito, S., Underwood, M.B., Kubo, Y., and the Expedition 322 Scientists, Proc. IODP, 322: Tokyo (Integrated Ocean Drilling Program Management International, Inc.). doi:10.2204/iodp.proc.322.104.2010

Expedition 333 Scientists, 2012a. Methods. In Henry, P., Kanamatsu, T., Moe, K., and the Expedition 333 Scientists, Proc. IODP, 333: Tokyo (Integrated Ocean Drilling Program Management International, Inc.). doi:10.2204/iodp.proc.333.102.2012

Expedition 333 Scientists, 2012b. Site C0011. In Henry, P., Kanamatsu, T., Moe, K., and the Expedition 333 Scientists, Proc. IODP, 333: Tokyo (Integrated Ocean Drilling Program Management International, Inc.). doi:10.2204/iodp.proc.333.104.2012

Gee, J., Staudigel, H., and Tauxe, L., 1989. Contribution of induced magnetization to magnetization of seamounts. Nature (London, U. K.), 342(6246):170-173. doi:10.1038/342170a0

Henry, P., 1997. Relationship between porosity, electrical conductivity, and cation exchange capacity in Barbados wedge sediments. In Shipley, T.H., Ogawa, Y., Blum, P., and Bahr, J.M. (Eds.), Proc. ODP, Sci. Results, 156: College Station, TX (Ocean Drilling Program), 137-149. doi:10.2973/odp.proc.sr.156.020.1997

Hayashida, A., Kamata, H., and Danhara, T., 1996. Correlation of widespread tephra deposits based on paleomagnetic directions: link between a volcanic field and sedimentary sequences in Japan. Quat. Int., 34-36:8998. doi:10.1016/1040-6182(95)00072-0

Ike, T., Moore, G.F., Kuramoto, S., Park, J-O., Kaneda, Y., and Taira, A., 2008. Tectonics and sedimentation around Kashinosaki Knoll: a subducting basement high in the eastern Nankai Trough. Isl. Arc, 17(3):358-375. doi:10.1111/j.1440-1738.2008.00625.x

Martini, E., 1971. Standard Tertiary and Quaternary calcareous nannoplankton zonation. Proc. Second Planktonic Conf. Roma 1970, 2:739-785.

Raffi, I., Backman, J., Fornaciari, E., Pälike, H., Rio, D., Lourens, L., and Hilgen, F., 2006. A review of calcareous nannofossil astrobiochronology encompassing the past 25 million years. Quat. Sci. Rev., 25(23-24):3113-3137. doi:10.1016/j.quascirev.2006.07.007

Saito, S., Underwood, M.B., Kubo, Y., and the Expedition 322 Scientists, 2010. Proc. IODP, 322: Tokyo (Integrated Ocean Drilling Program management International, Inc.). doi:10.2204/iodp.proc.322.2010

Satoguchi, Y., Higuchi, Y., and Kurokawa, K., 2005. Correlation of the Ohta tephra bed in the Tokai group with a tephra in the Miura group, central Japan. Chishitsugaku Zasshi, 111(2):74-86.

Taylor, S.R., and McLennan, S.M., 1985. The Continental Crust: Its Composition and Evolution: Oxford (Blackwell Scientific).

Tissot, B.P., and Welte, D.H., 1984. Petroleum Formation and Occurrence (2nd ed.): Heidelberg (Springer-Verlag).

Tobin, H., Kinoshita, M., Ashi, J., Lallemant, S., Kimura, G., Screaton, E.J., Moe, K.T., Masago, H., Curewitz, D., and the Expedition 314/315/316 Scientists, 2009. NanTroSEIZE Stage 1 expeditions: introduction and synthesis of key results. In Kinoshita, M., Tobin, H., Ashi, J., Kimura, G., Lallemant, S., Screaton, E.J., Curewitz, D., Masago, H., Moe, K.T., and the Expedition 314/315/316 Scientists, Proc. IODP, 314/315/316: Washington, DC (Integrated Ocean Drilling Program Management International, Inc.). doi:10.2204/ iodp.proc.314315316.101.2009

Underwood, M.B., Saito, S., Kubo, Y., and the Expedition 322 Scientists, 2010. Expedition 322 summary. In Saito, S., Underwood, M.B., Kubo, Y., and the Expedition 322 Scientists, Proc. IODP, 322: Tokyo (Integrated Ocean Drilling Program Management International, Inc.). doi:10.2204/iodp.proc.322.101.2010

Yamamoto, Y., Ogawa, Y., Uchino, T., Muraoka, S., and Chiba, T., 2007. Large-scale chaotically mixed sedimentary body within the late Pliocene to Pleistocene Chikura group, central Japan. Isl. Arc, 16(4):505-507. doi:10.1111/j.1440-1738.2007.00587.x

Zhao, X., Roperch, P., and Stokking, L.B., 1994. Magnetostratigraphy of the north Aoba Basin. In Greene, H.G., Collot, J.-Y., Stokking, L.B., et al., Proc. ODP, Sci. Results, 134: College Station, TX (Ocean Drilling Program), 457474. doi:10.2973/odp.proc.sr.134.025.1994

Publication: 18 May 2012

MS 333-105 
Figure F1. Detailed bathymetric map of Kashinosaki Knoll and Nankai Trough showing location of Sites C0011, C0012, and C0018.

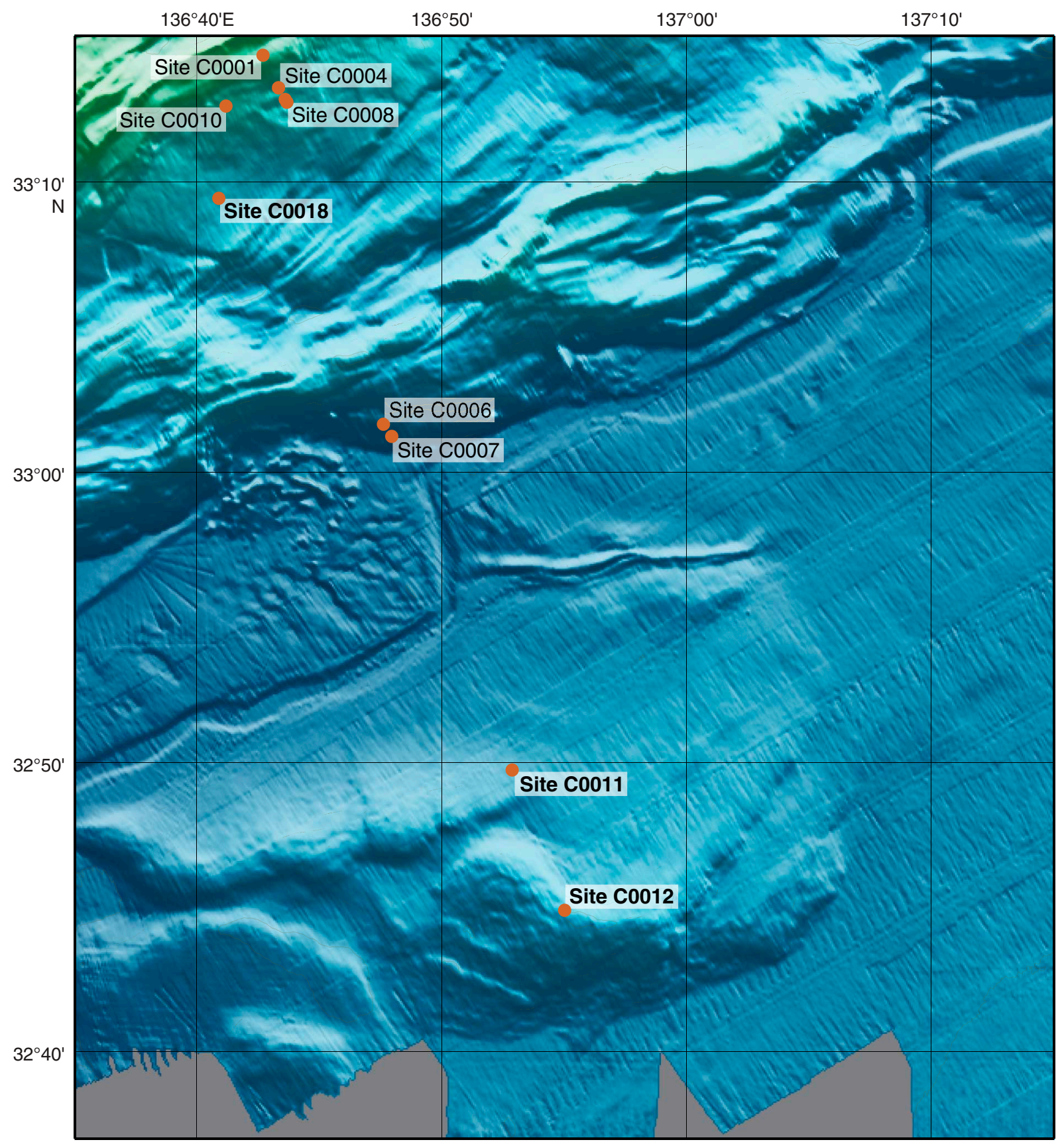


Figure F2. Lithologic columns on seismic background across Kashinosaki Knoll showing Sites C0011 and C0012, using results from Expeditions 333 and 322 (Underwood et al., 2010). VE = vertical exaggeration.

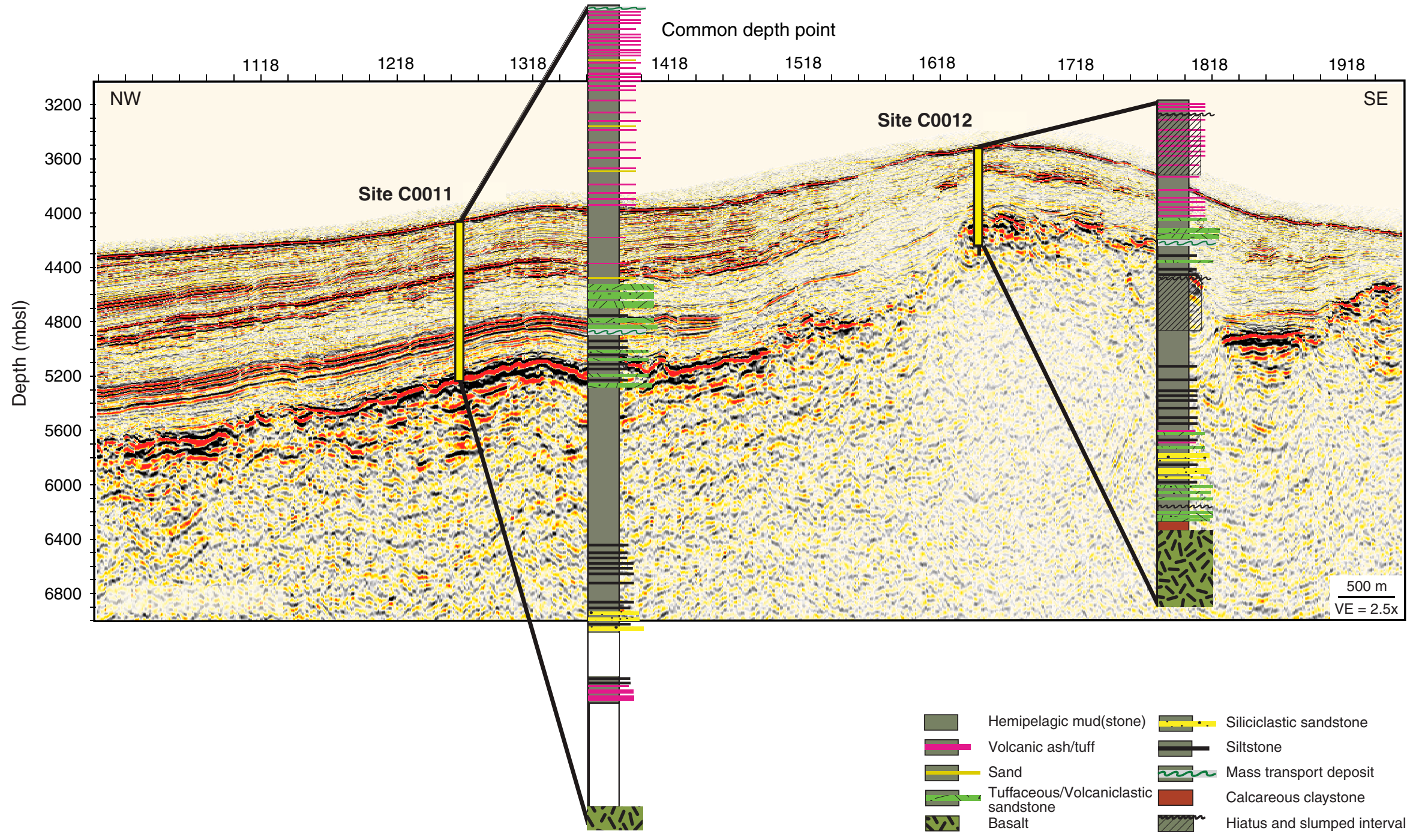


Figure F3. Sedimentary log of Holes C0012C and C0012D showing the lithologic units and subunits identified, main lithologies, and corresponding recovery rates.

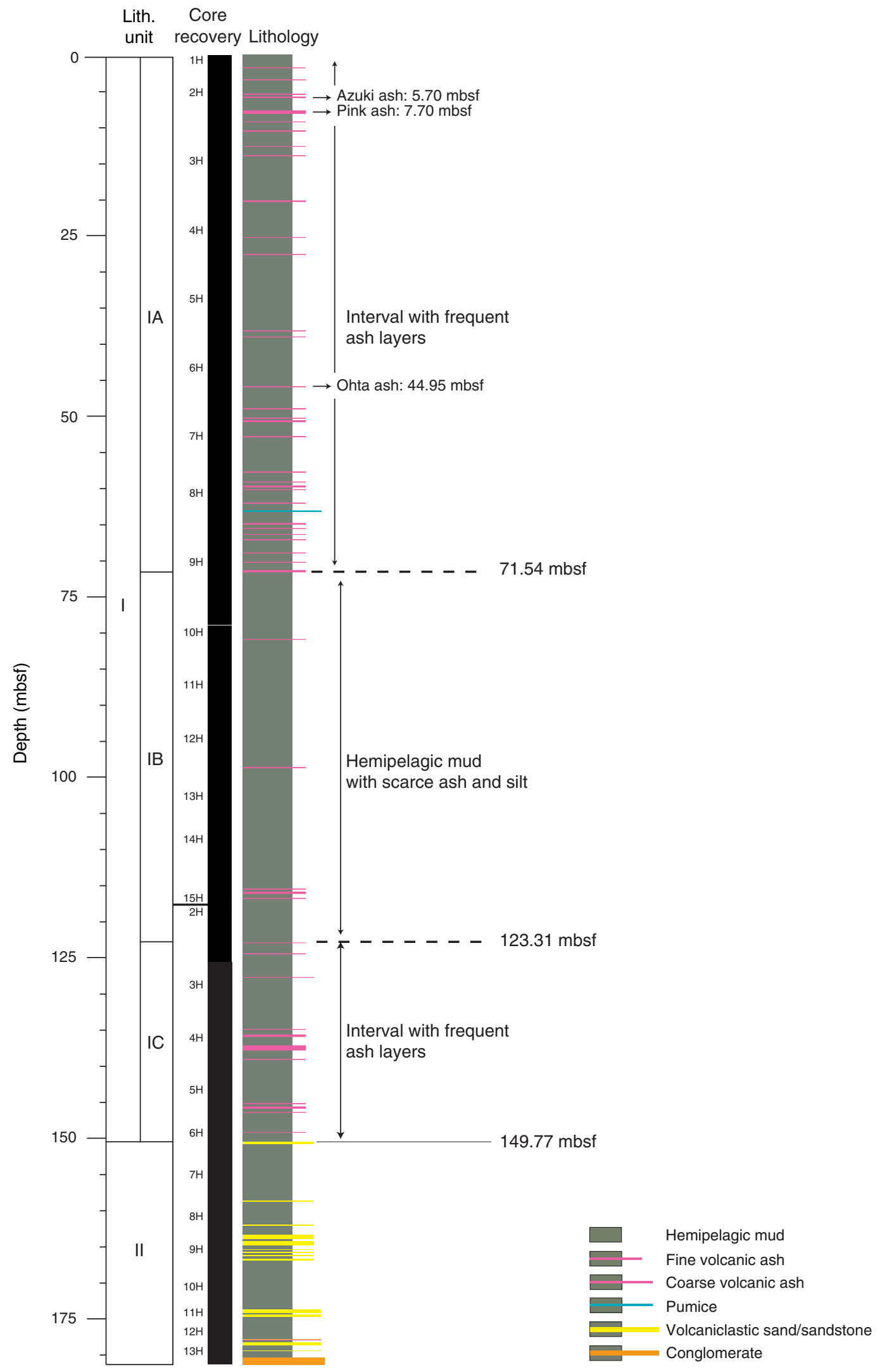


Figure F4. Occurrence of depositional ash and sand event beds, Holes C0012C and C0012D.

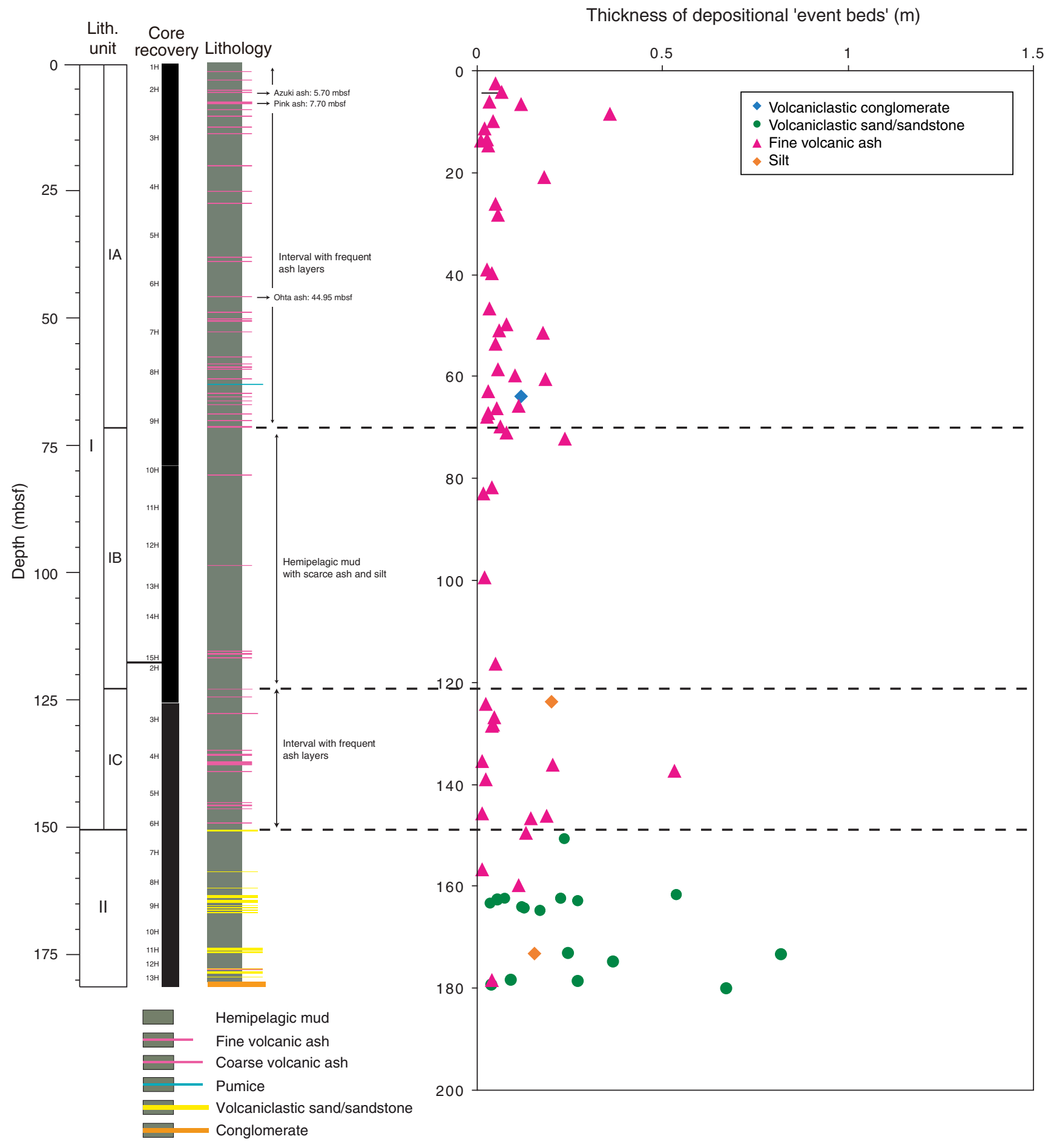


Figure F5. Detail of volcanic ash layers in Subunit IA. A. Ash layers occur together with green bands in the silty clay background sediment, a probable result from the accumulation of iron (Fe) in such bands (Section 333C0012C-2H-1) (see also Fig. F6 in the "Site C0011" chapter [Expedition 333 Scientists, 2012b]). B. Ash layers and patches of ash occurring within an interval showing evidence for disturbance from both drilling and in situ deformation (Section 333-C0012C-2H-5). C, D. Details from lower part of Subunit IA showing tilted color bands and ash layers, some faulting and folding of the green bands. C. Section 333-C0012C-4H-8. D. Section 333-C0012C-3H-7. $\mathrm{F}$ = faults.

A cm

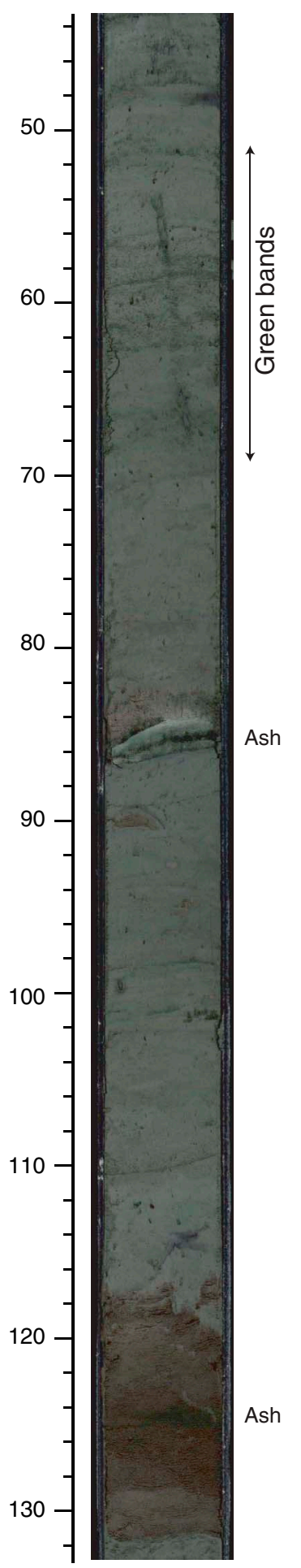

B cm

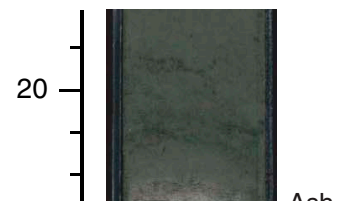

Ash
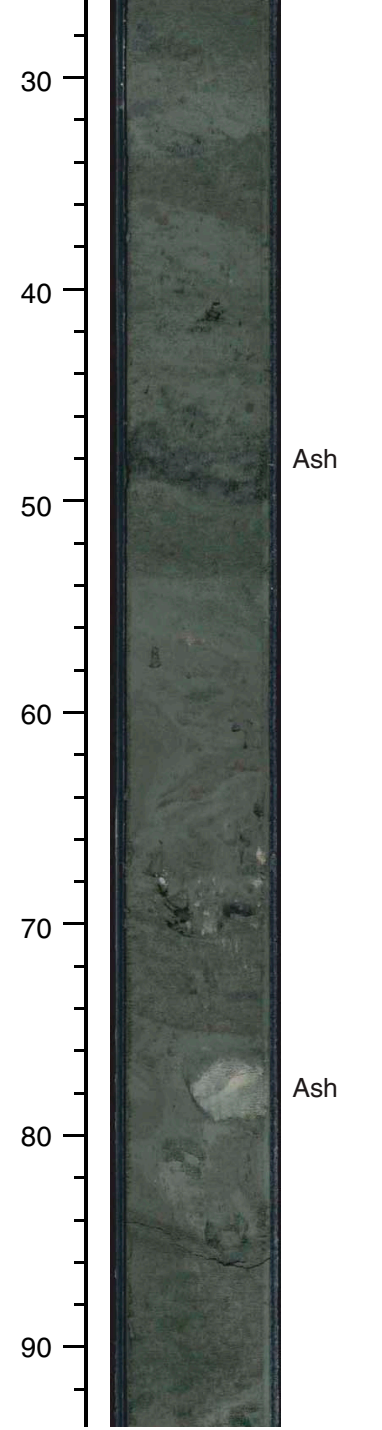

$\mathbf{C}_{\mathrm{cm}}$

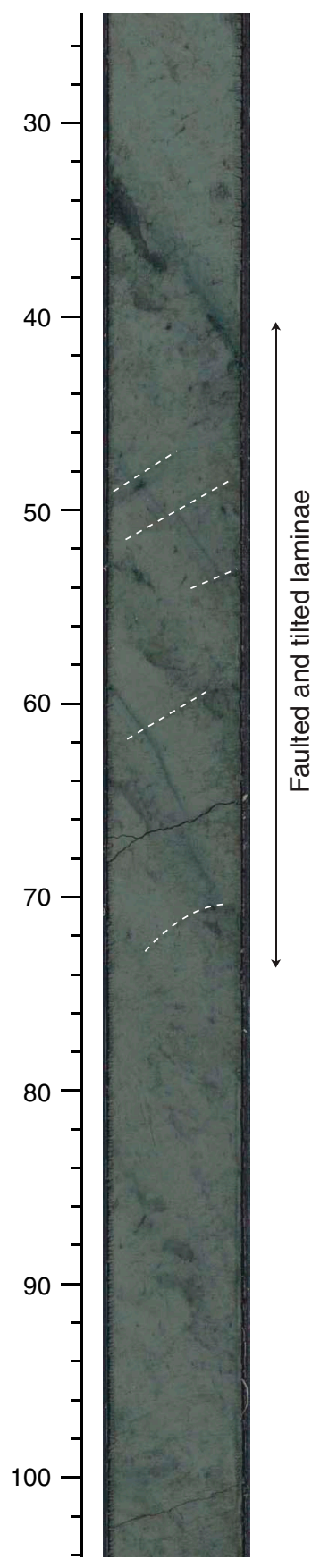

$\mathbf{D}_{\mathrm{cm}}$

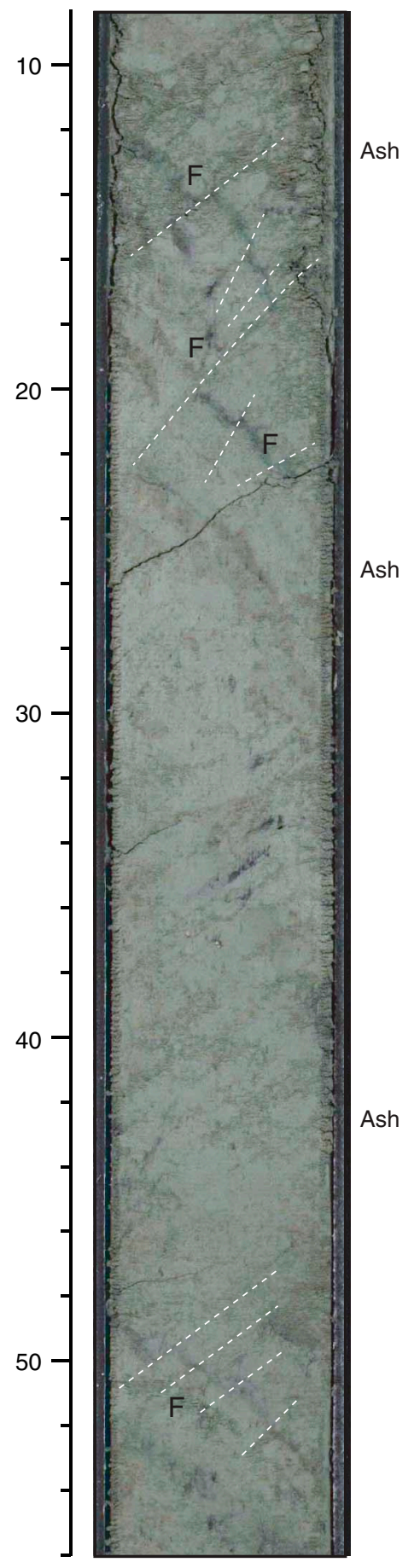


Figure F6. Details of volcanic ash layers and their smear slides in Core 333-C0012C-2H. A. Detail of Section 333-C0012C-2H-1, showing possible correlative to the Azuki volcanic ash. B. Smear slide of Sample 333C0012C-2H-1, $131 \mathrm{~cm}$, which contains abundant bubble wall type glass shards and obsidian grains (e.g., center of photo) typical for the Azuki volcanic ash bed (Hayashida et al., 1996, and references therein). C. Detail of Section 333-C0012C-2H-3, showing possible correlative to the Pink volcanic ash. D. Smear slide photo of volcanic ash in Sample 333-C0012C-2H-3, $72 \mathrm{~cm}$, showing fibrous bubble wall type glass shards and abundant hornblendes as heavy minerals (e.g., green colored mineral in upper right side), which are distinct characteristics for the Pink volcanic ash (Hayashida et al., 1996, and references therein).

A

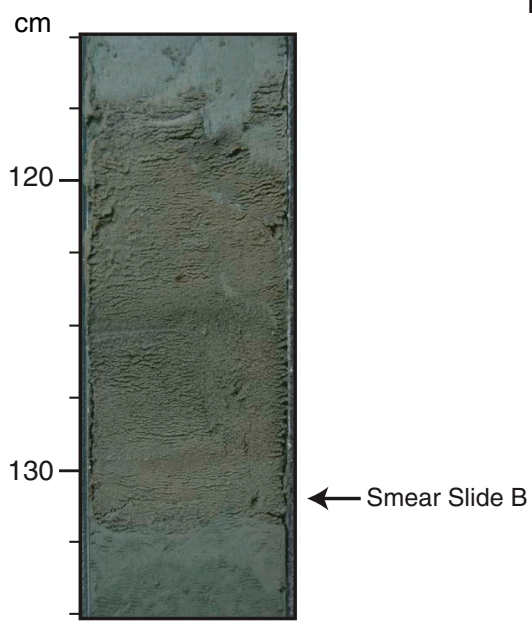

C

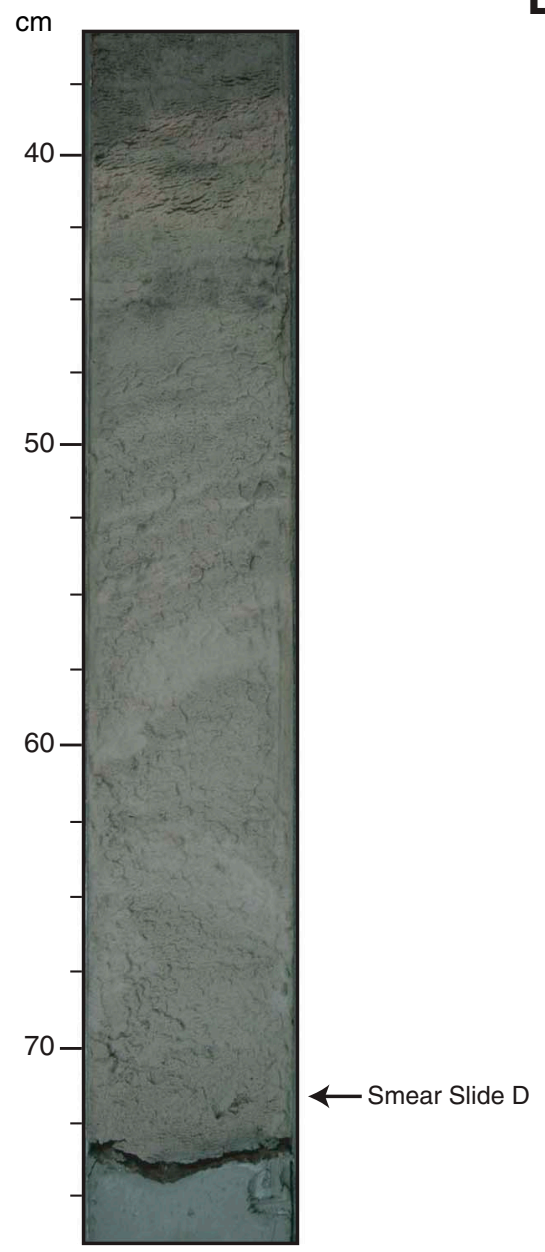

B

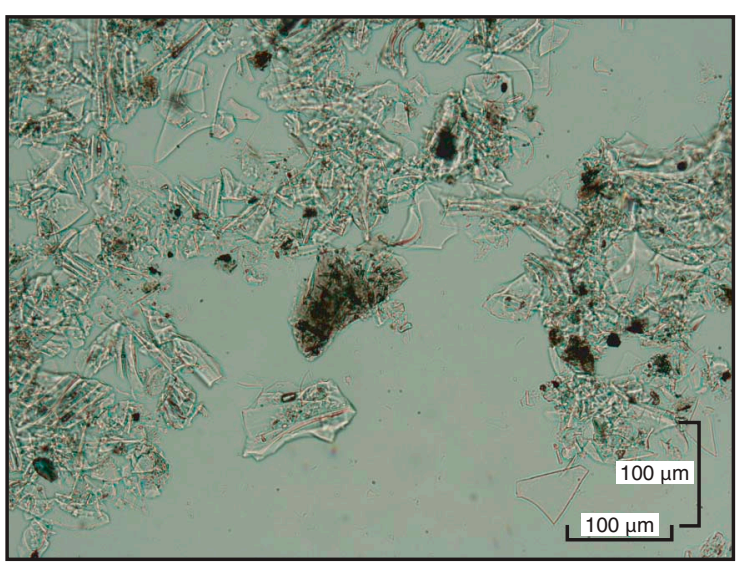

D

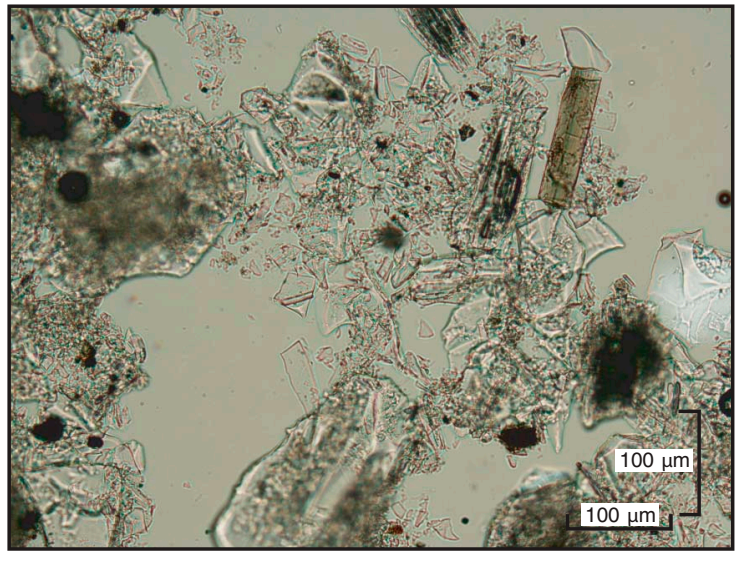


Figure F7. Summary figure illustrating change in degree of ash alteration, which occurs somewhere between 60 and 90 mbsf in Hole C0012C. A. Detail of Section 333-C0012C-7H-8. B. Fresh volcanic glass on a smear slide of Sample 333-C0012C-7H-8, 17 cm (at 59.24 mbsf, within lower part of Subunit IA). C. Detail of Section 333C0012C-11H-5. D. Altered glass on a smear slide of Sample 333-C0012C-11H-5, $30 \mathrm{~cm}$ (at 91.19 mbsf, within upper part of Subunit IB).

A

$\mathrm{cm}$

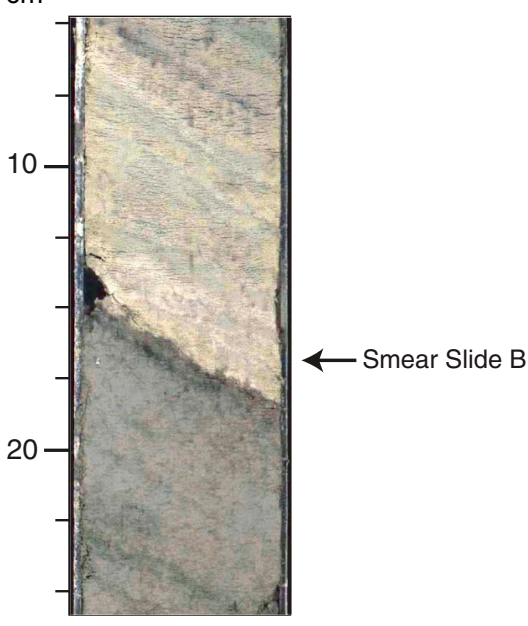

C

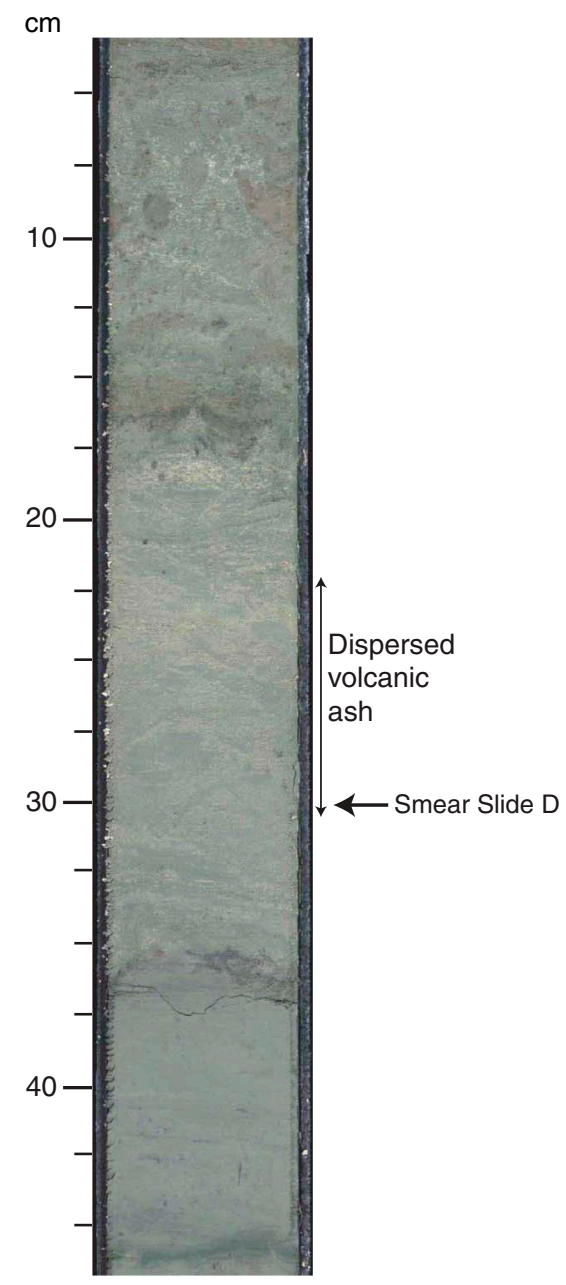

B

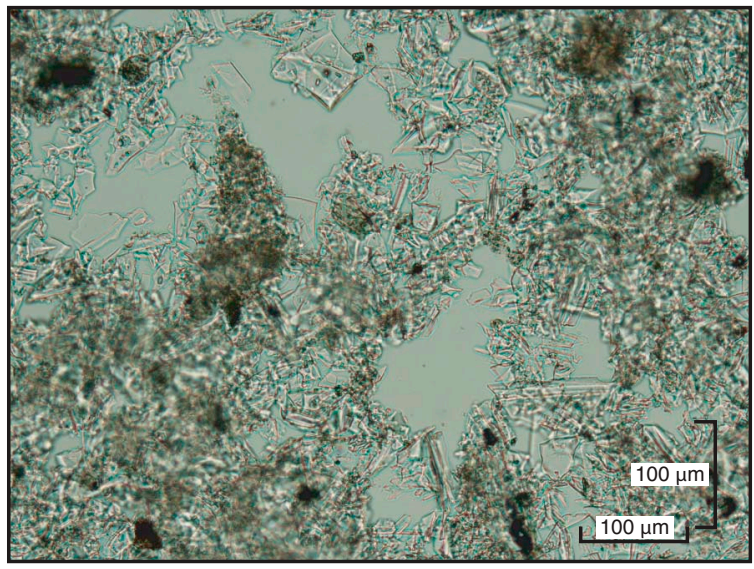

D

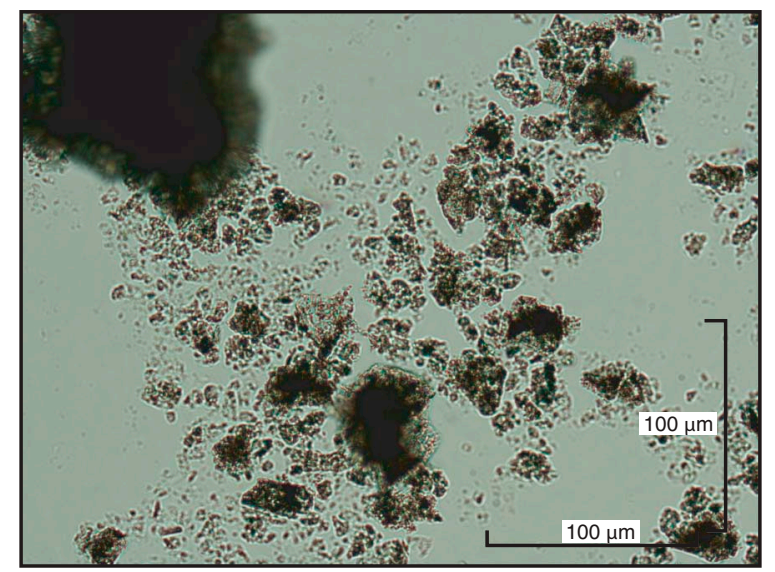


Figure F8. Example of volcaniclastic sand containing mudclasts within lithologic Unit II. A. Core photo of Section 333-C0012D-9H-1. B. Smear slide of Sample 333-C0012D-9H-1, $55 \mathrm{~cm}$, which predominantly contains altered volcanic glass.
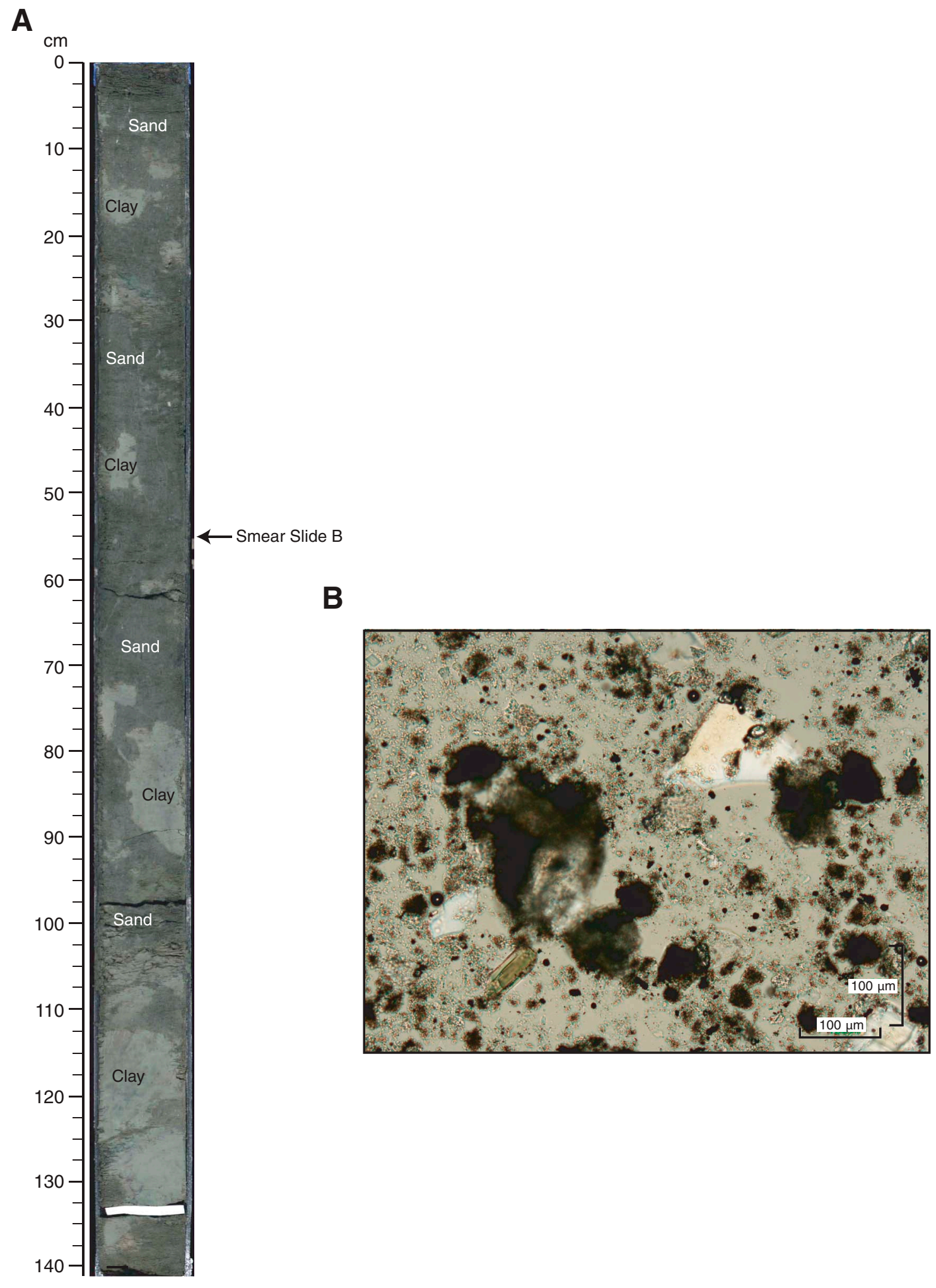
Figure F9. X-ray fluorescence core logging data of Sections 333-C0012E-3X-3 through 3X-8, highlighting variations in major oxides recorded over the sediment/basalt interface.

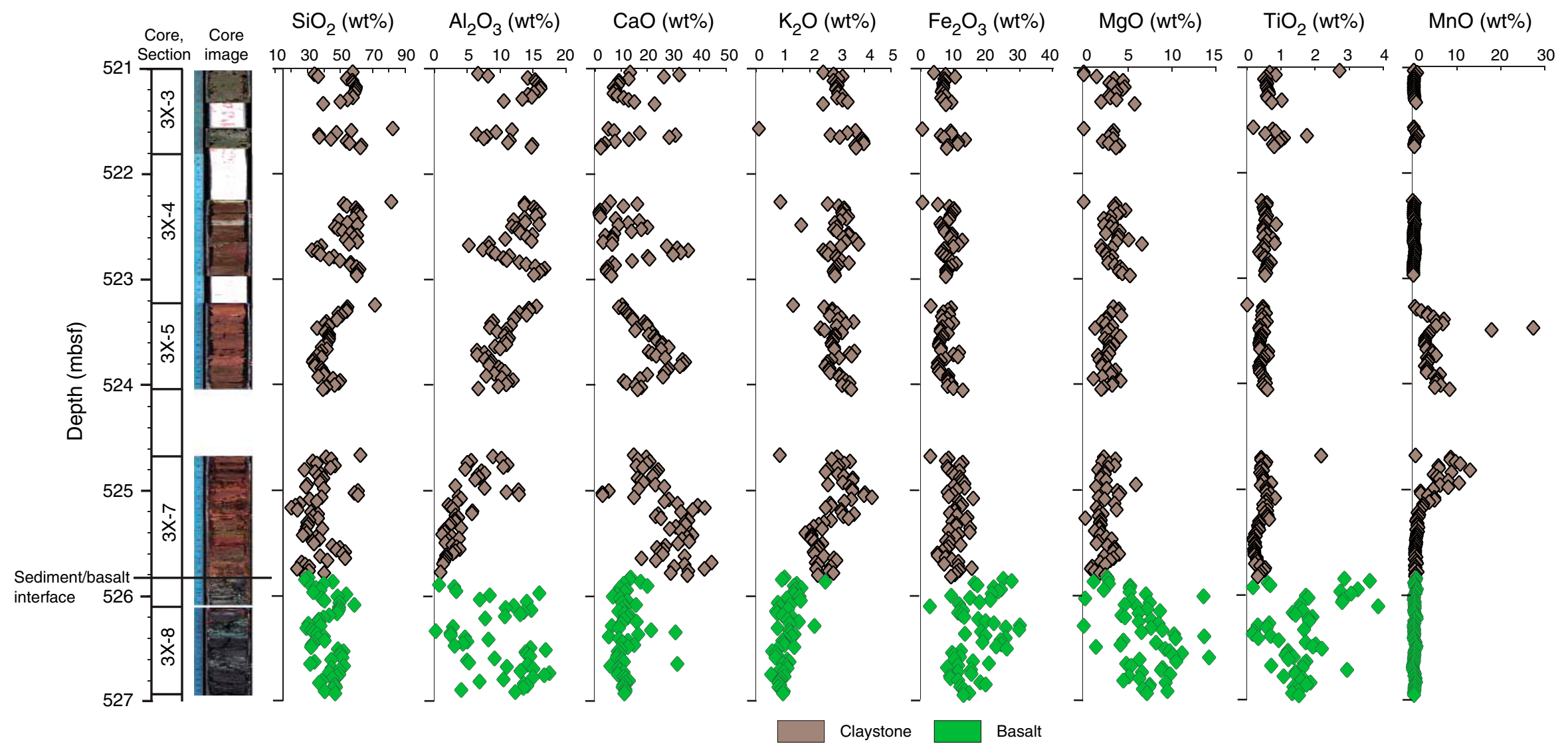


Figure F10. Summary of XRD data, Holes C0012C and C0012D.

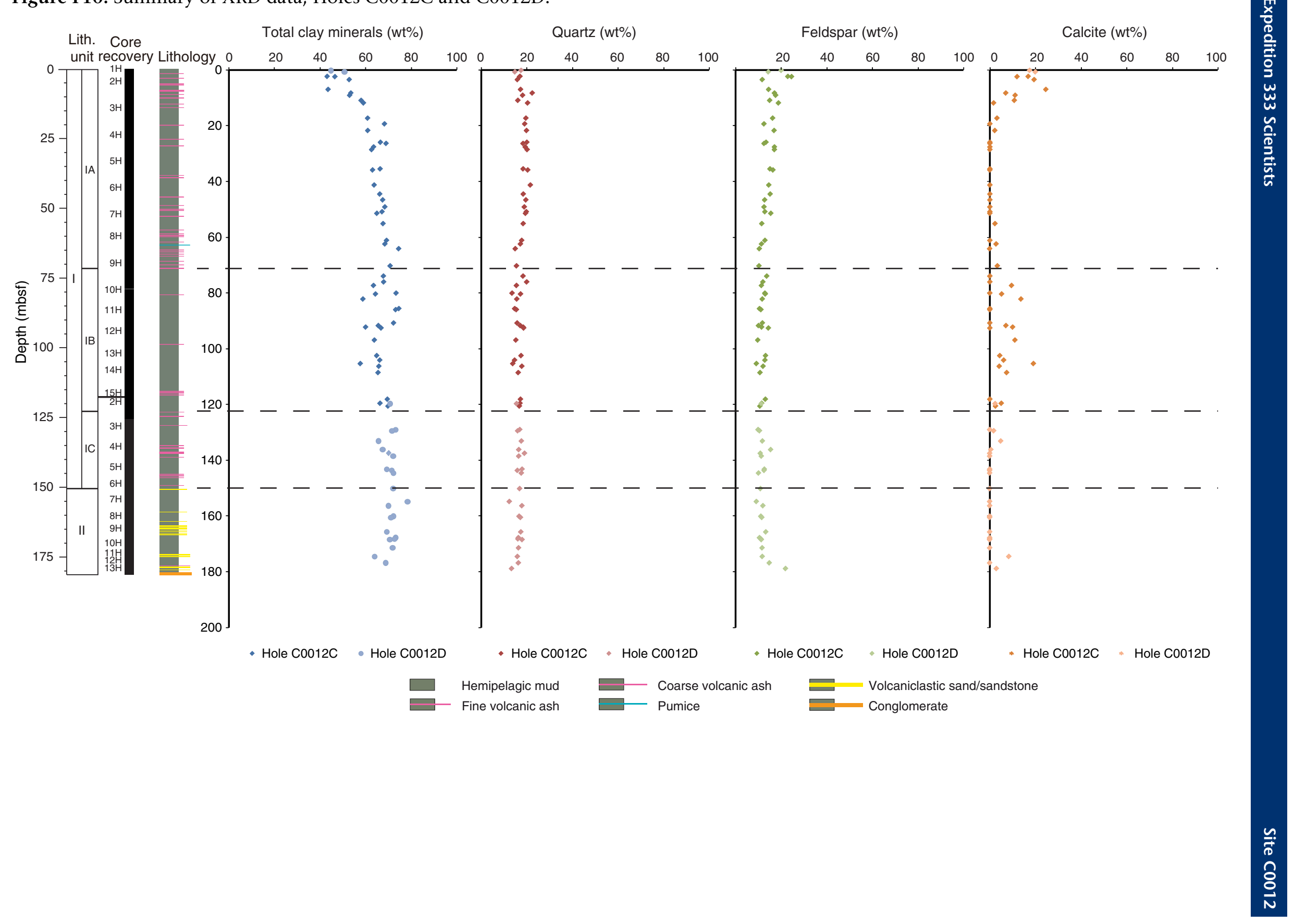


Figure F11. Discrete $\mathrm{X}$-ray fluorescence (XRF) results for major oxide $\left(\mathrm{SiO}_{2}, \mathrm{Al}_{2} \mathrm{O}_{3}, \mathrm{CaO}, \mathrm{Fe}_{2} \mathrm{O}_{3}, \mathrm{MgO}, \mathrm{MnO}\right.$, and $\left.\mathrm{P}_{2} \mathrm{O}_{5}\right)$ compositions as a function of depth, Site C0012.

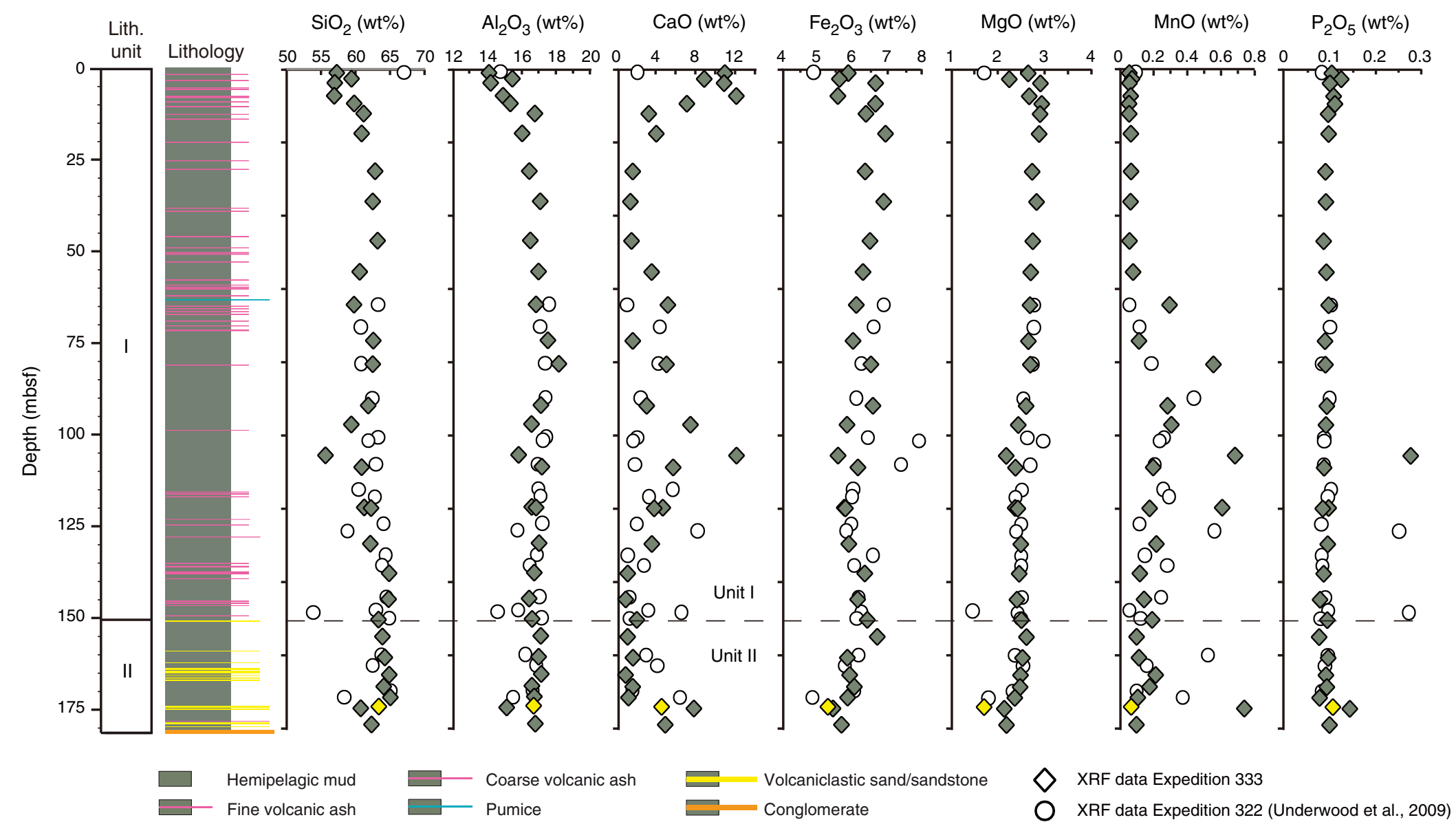


Figure F12. Dip angle variations of bedding, faults, and shear zones with depth, Holes C0012C and C0012D. Lines $=$ boundaries between four zones based on dipping angle distribution patterns (Zones I-IV).

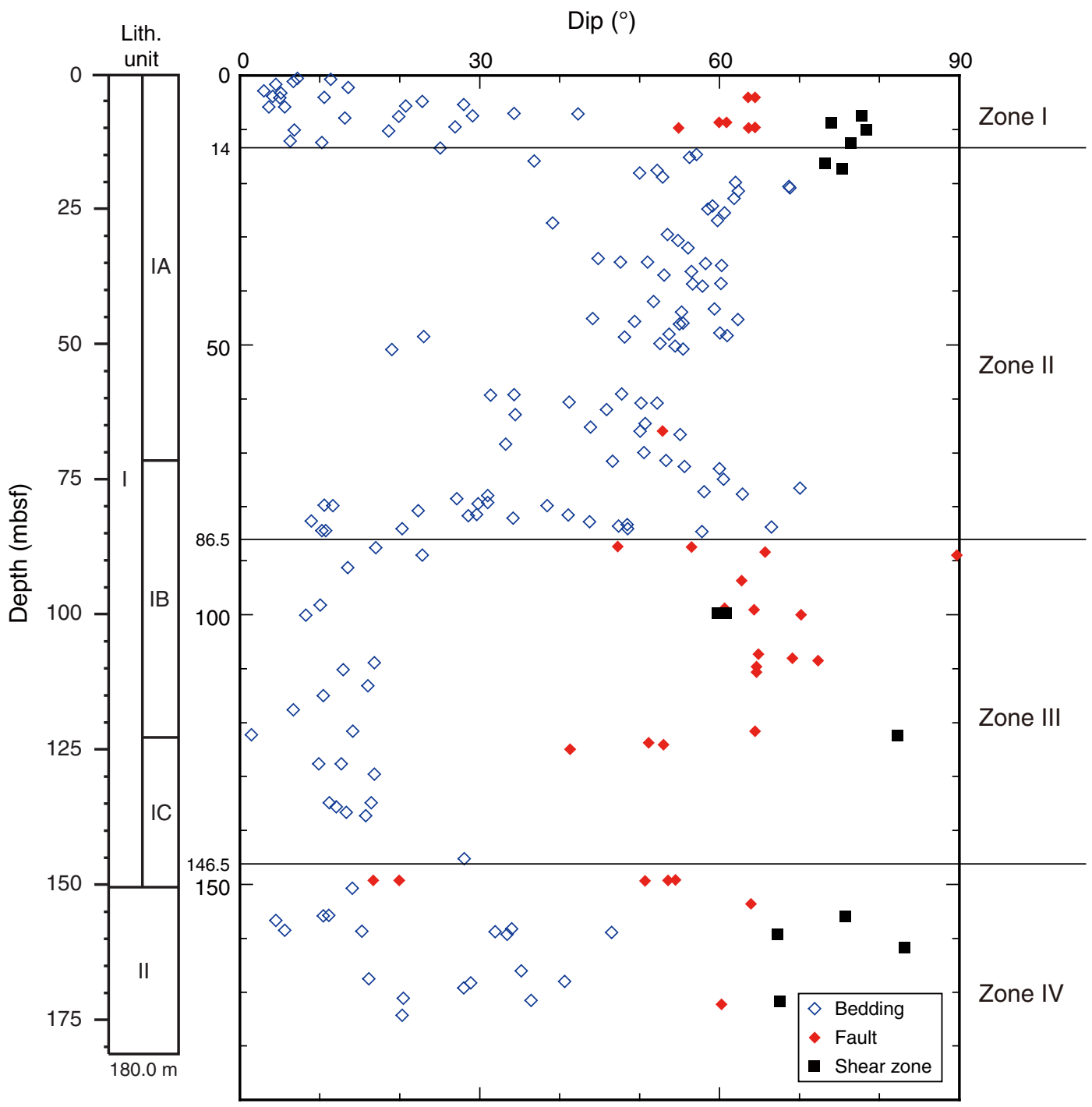


Figure F13. Lower hemisphere equal area stereographic projection of poles to bedding planes in Zone I, Site C0012.

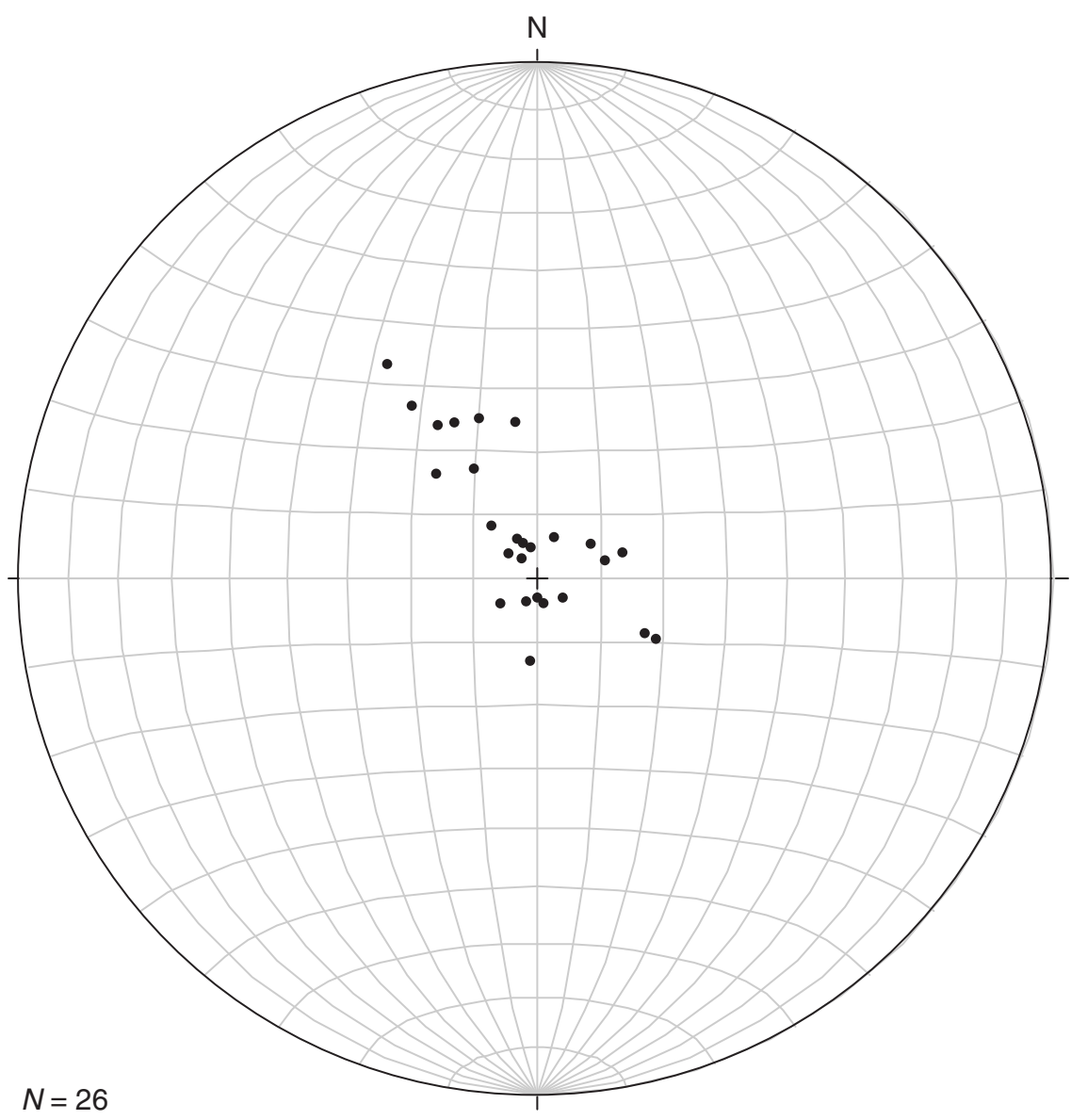


Figure F14. Lower hemisphere equal area projection showing poles and planes of tilted bedding in Zone II (1486.5 mbsf), Site C0012.

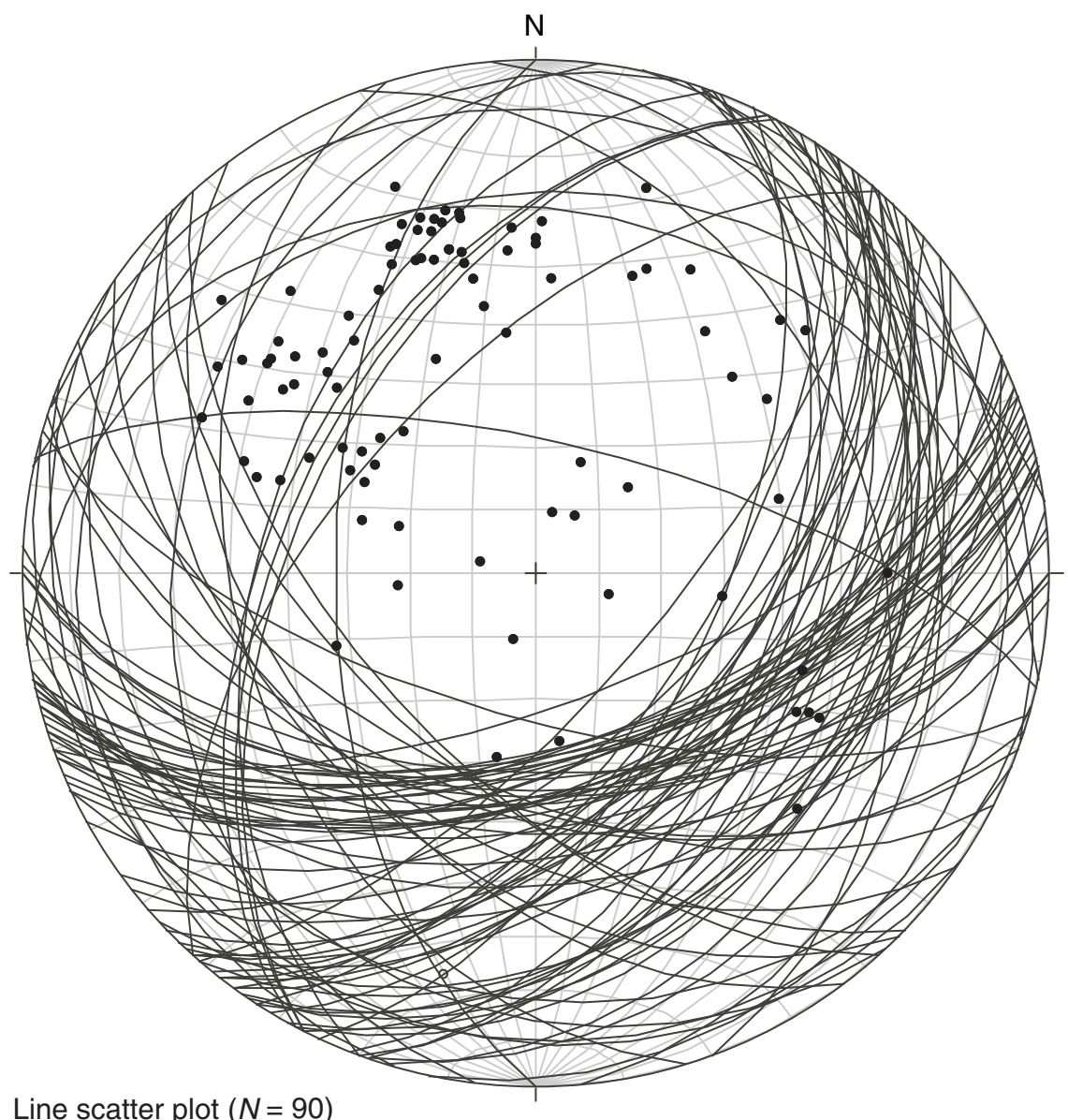

Line scatter plot $(N=90)$

Planes $(N=90)$ 
Figure F15. Appearance of high-angle normal fault (interval 333-C0012C-12H-2, 95-110 cm), which is commonly observed in Zones I and III. Red triangles = location of fault, white arrows = offset of fault. MSCL-I = photo image logger, $\mathrm{CT}=$ computed tomography.
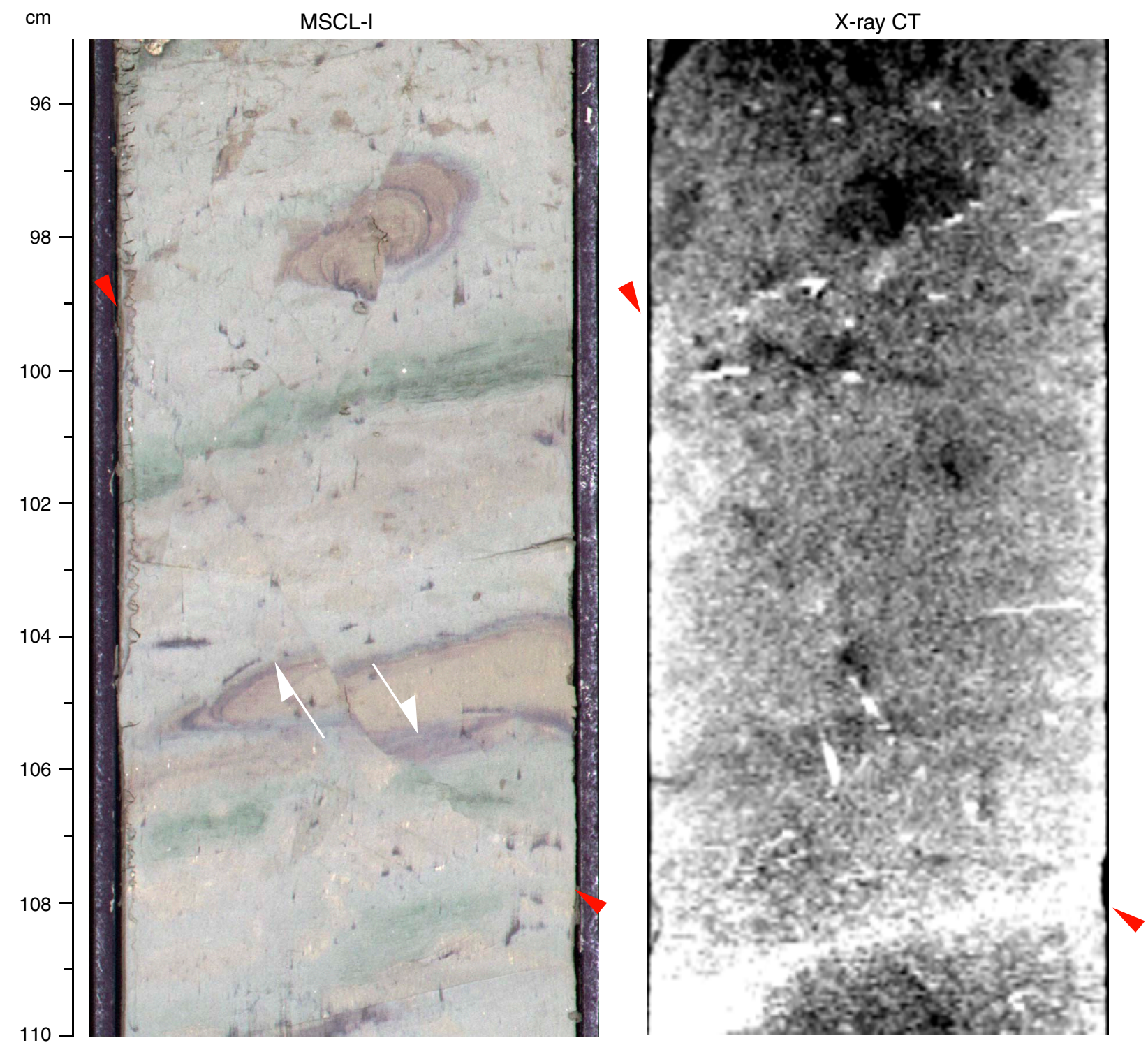
Figure F16. Lower hemisphere equal area projection of poles and planes of faults, Holes C0012C and C0012D.

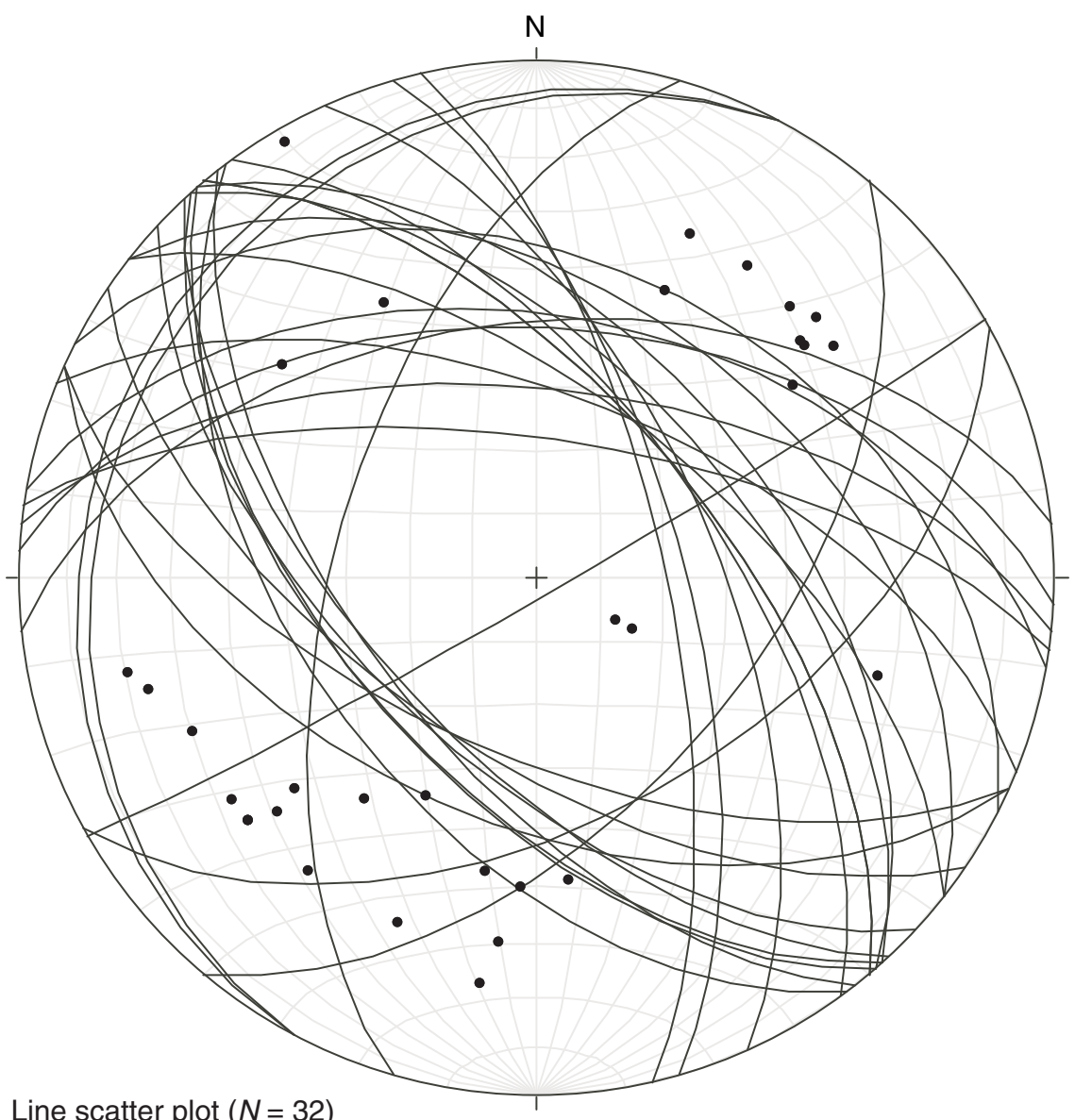

$N=32$

Planes $(N=32)$ 
Figure F17. Faulting likely to be interrupted by bioturbation (interval 333-C0012C-10H-9, 10-25 cm). MSCL-I = photo image logger, $\mathrm{CT}=$ computed tomography.
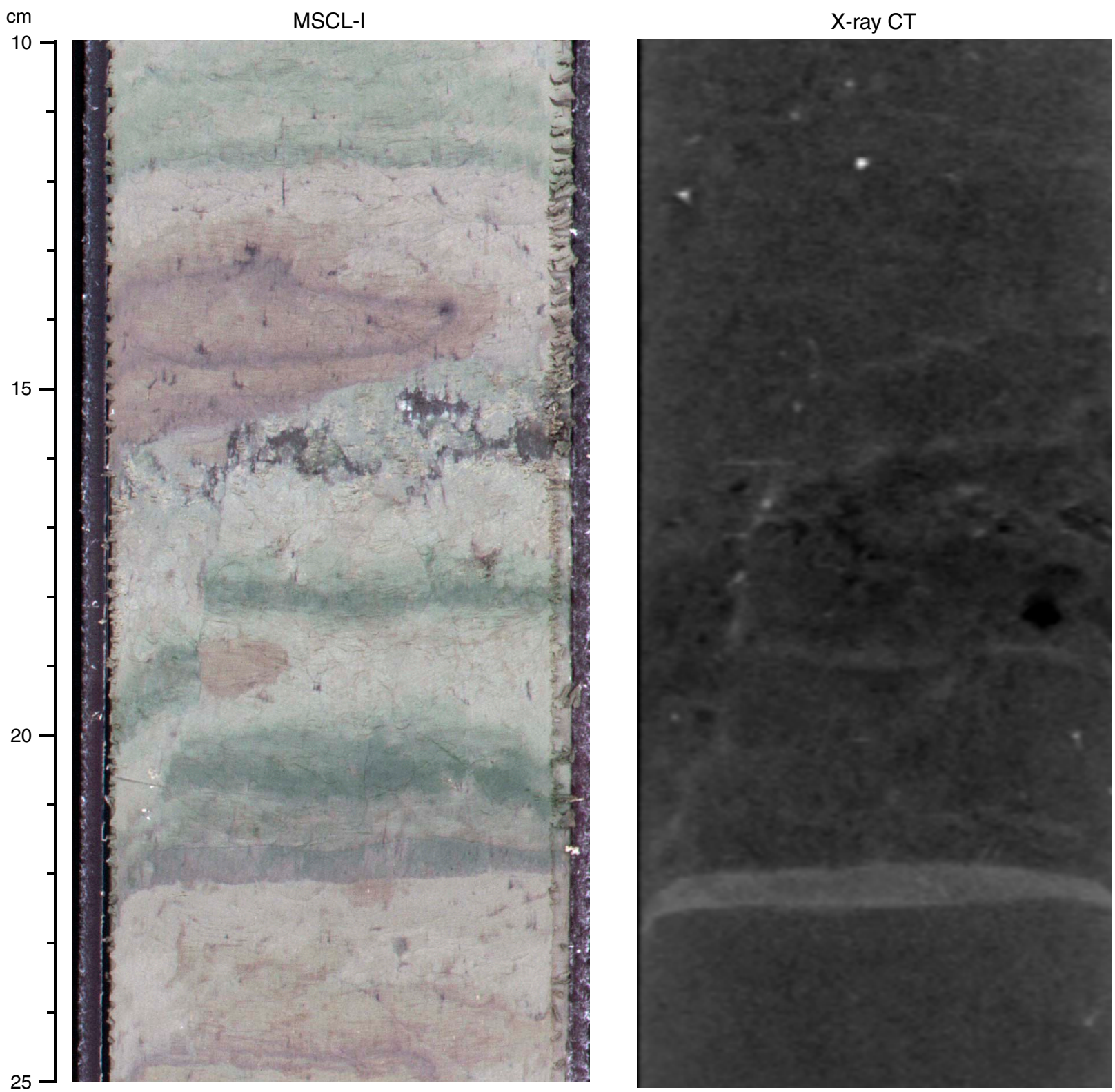
Figure F18. Fault sets showing a crosscutting relationship (interval 333-C0012D-5H-5, 90-100 cm). Red triangles $=$ location of fault. MSCL-I = photo image logger, CT = computed tomography.

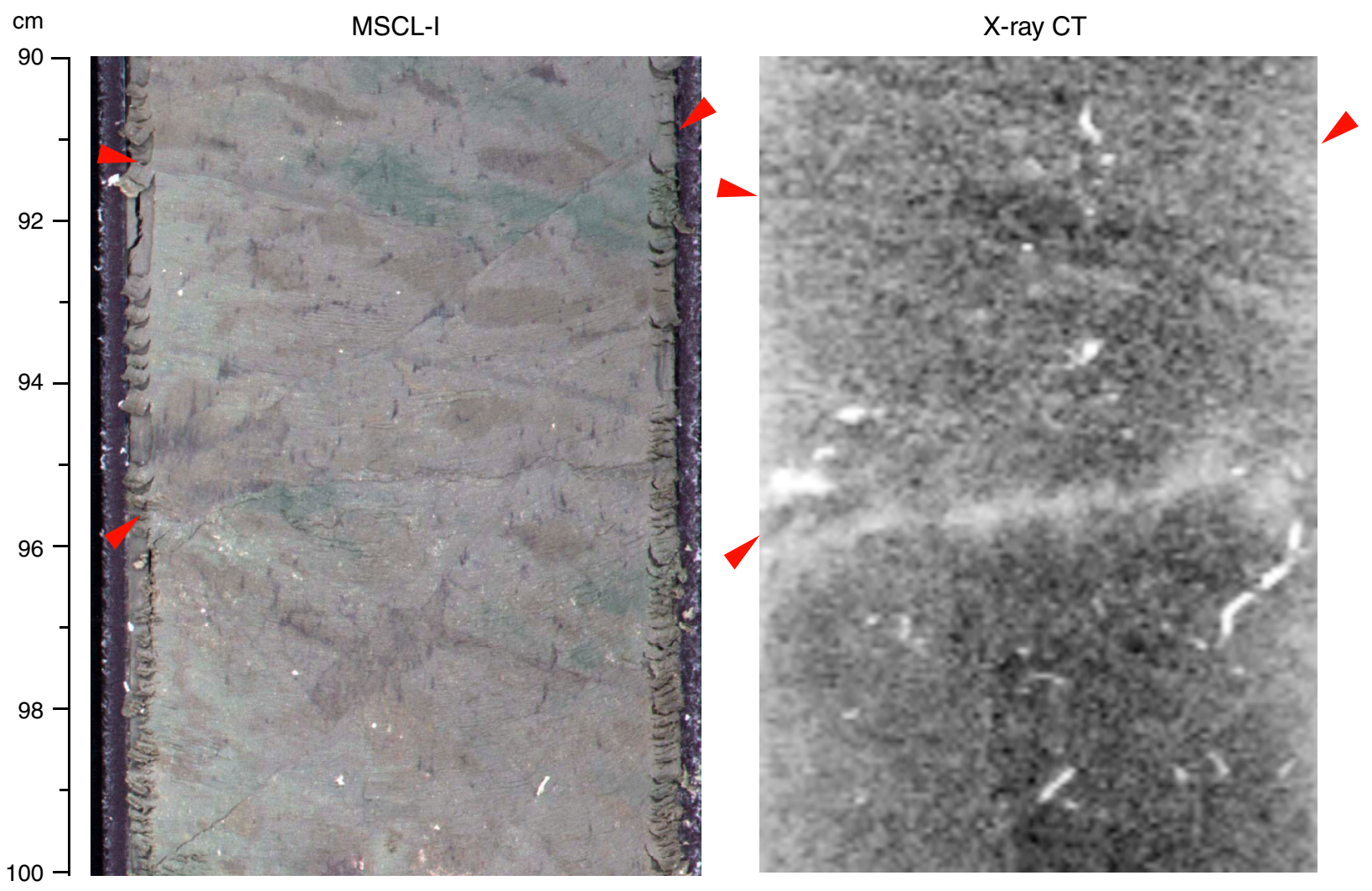


Figure F19. A thrust fault displaces burrow (interval 333-C0012D-2H-5, 70-85 cm). Red triangles $=$ location of fault, white arrows = offset of fault. MSCL-I = photo image logger, CT = computed tomography.

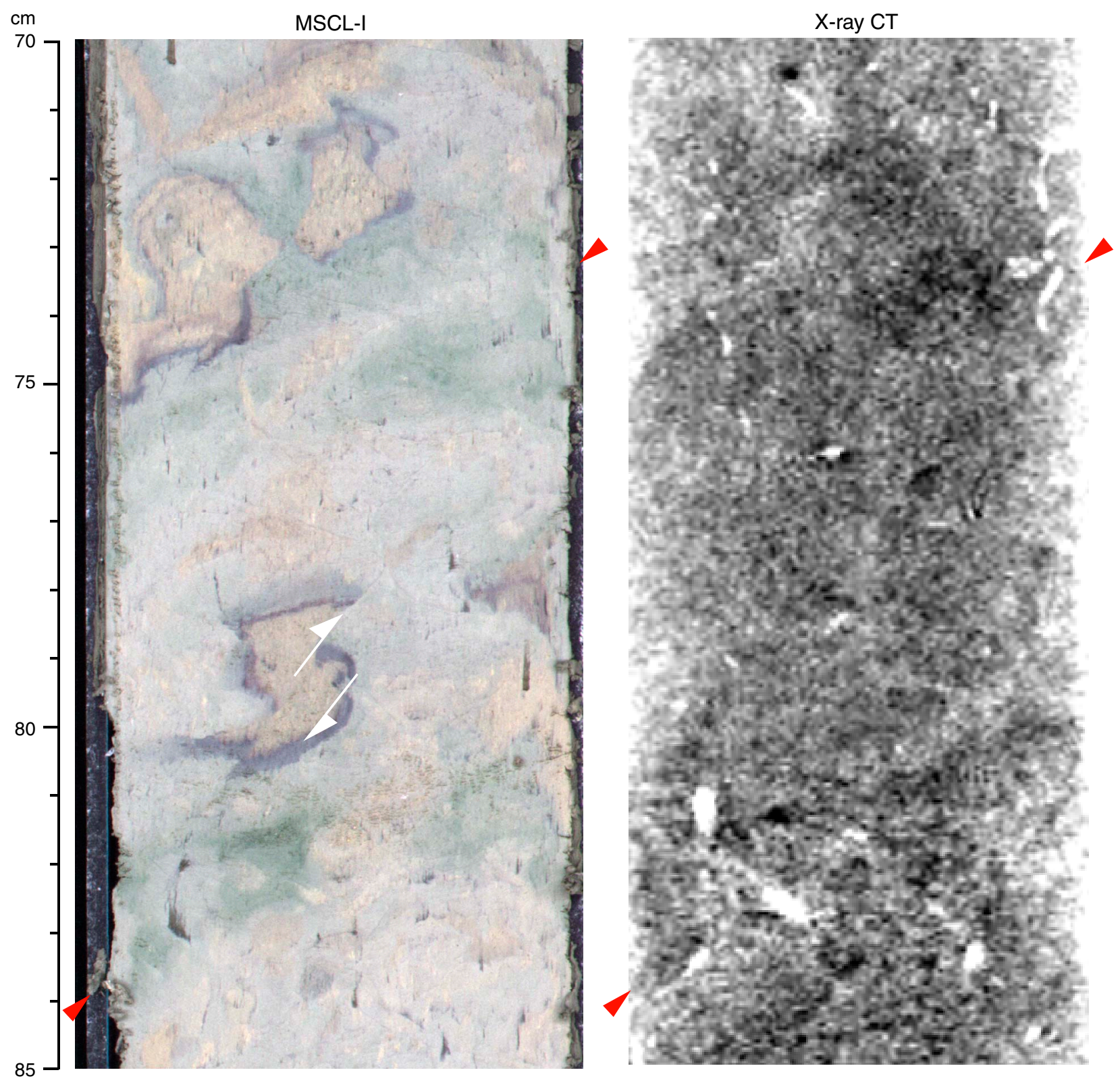


Figure F20. Occurrence of chaotic interval located at the bottom of Zone II, where ash layers are cut by planer structures (interval 333-C0012C-10H-8, 34-60 cm). MSCL-I = photo image logger, CT = computed tomography.

$\mathrm{cm}$

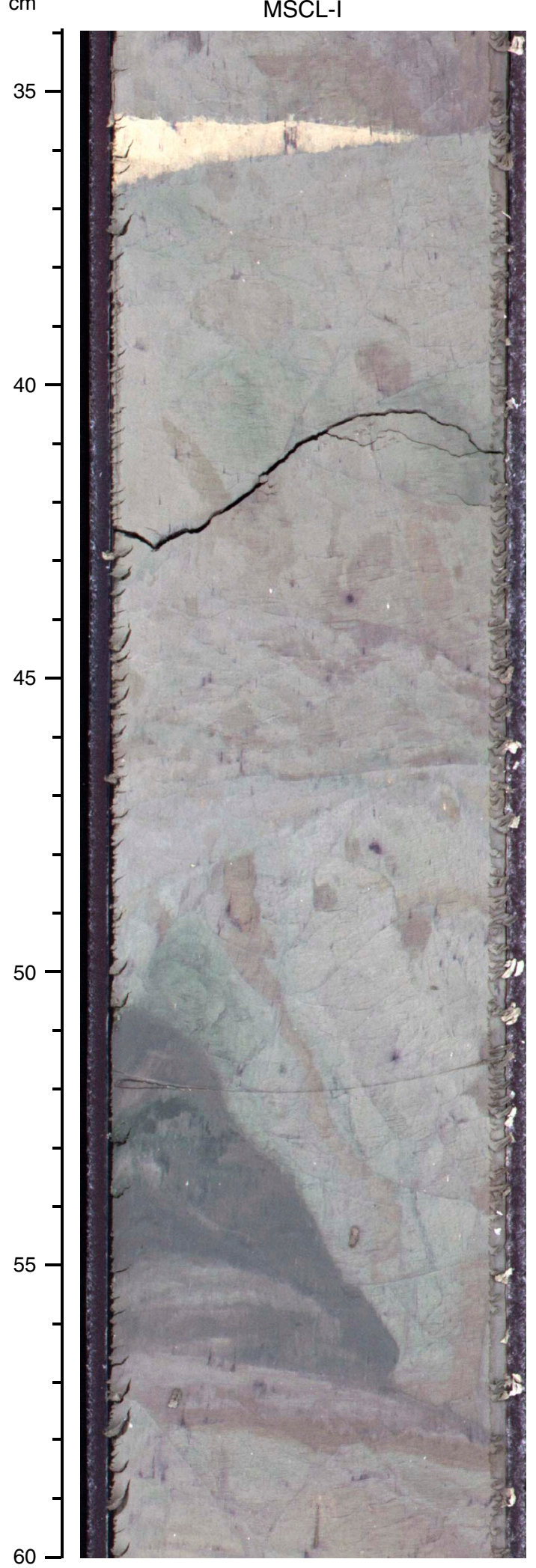

X-ray CT

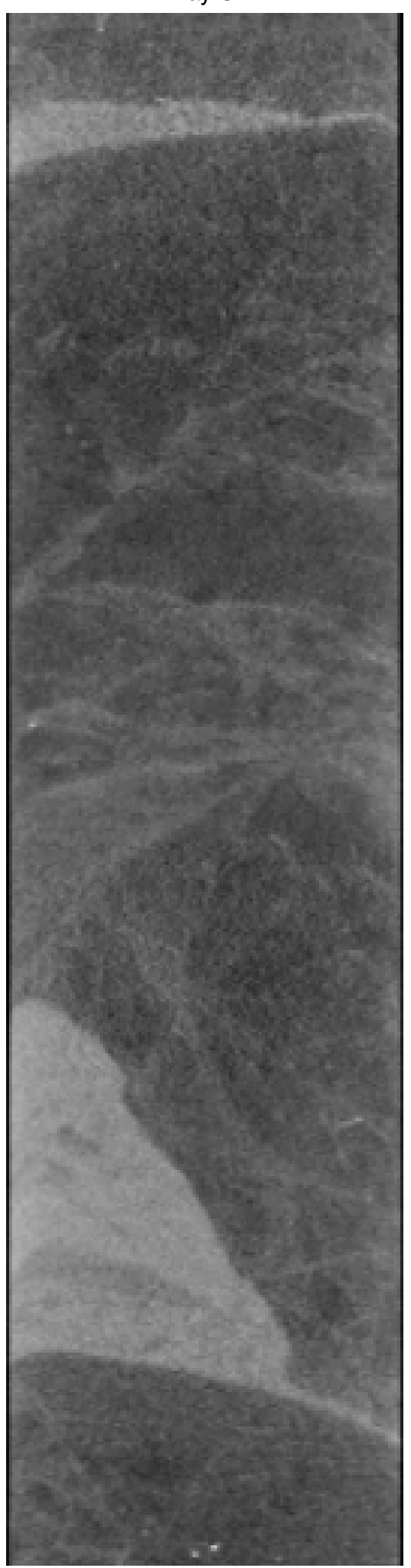


Figure F21. A dewatering structure within chaotic interval at the bottom of Zone II (interval 333-C0012D-10H$7,2-15 \mathrm{~cm}$ ). White dashed line = shape of plume-shaped head of dewatering structure. MSCL-I = photo image logger, CT = computed tomography.
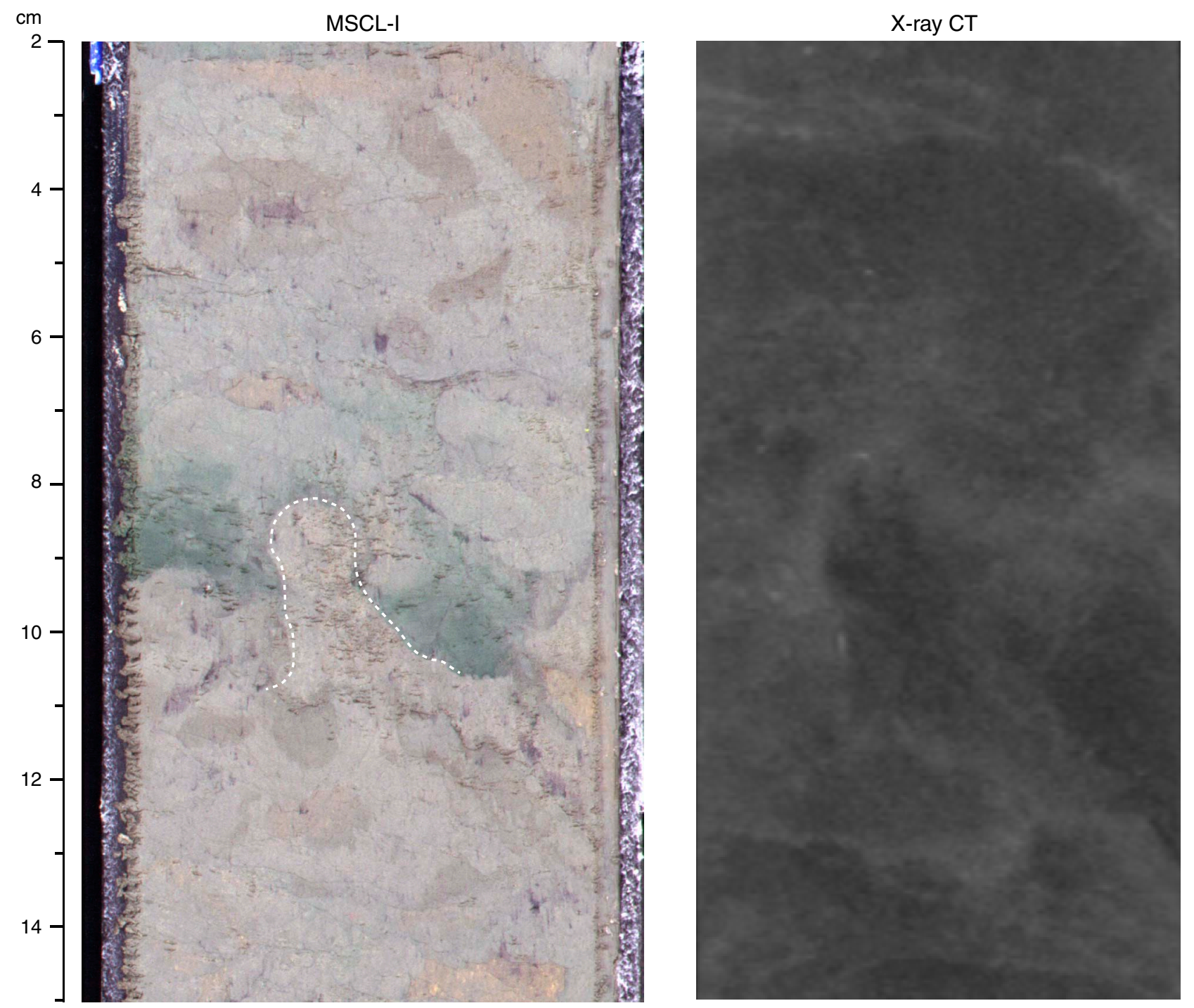
Figure F22. Muddy sand including clasts of silt (interval 333-C0012D-6H-5, 0-30 cm). This lithology forms the matrix of chaotic interval. Note that muddy sand is truncated by a later high-angle fault. MSCL-I = photo image logger, CT = computed tomography.
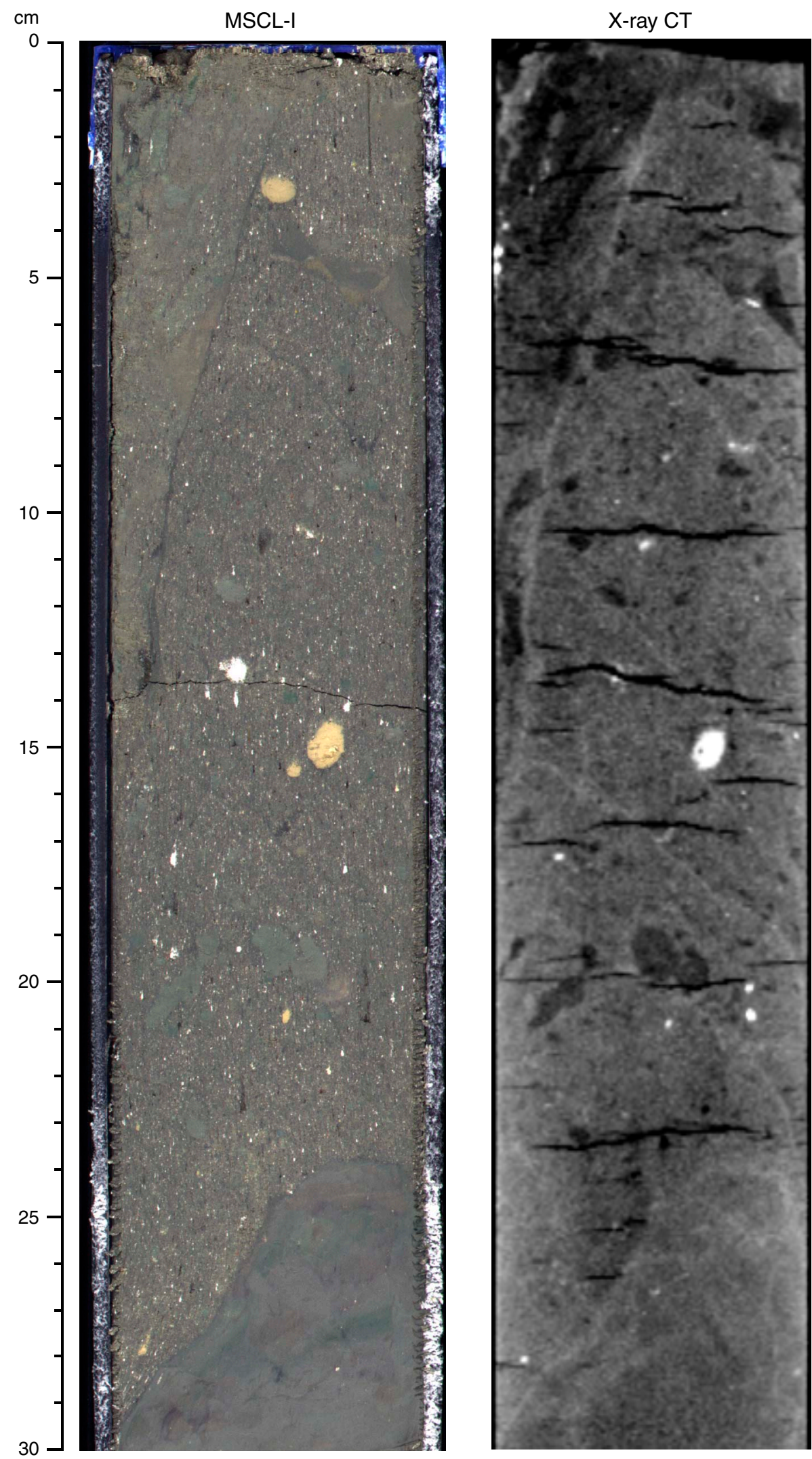
Figure F23. Shear zone showing high-angle dips with large displacement (interval 333-C0012D-7H-4, 63-95 $\mathrm{cm})$. MSCL-I = photo image logger, CT = computed tomography.

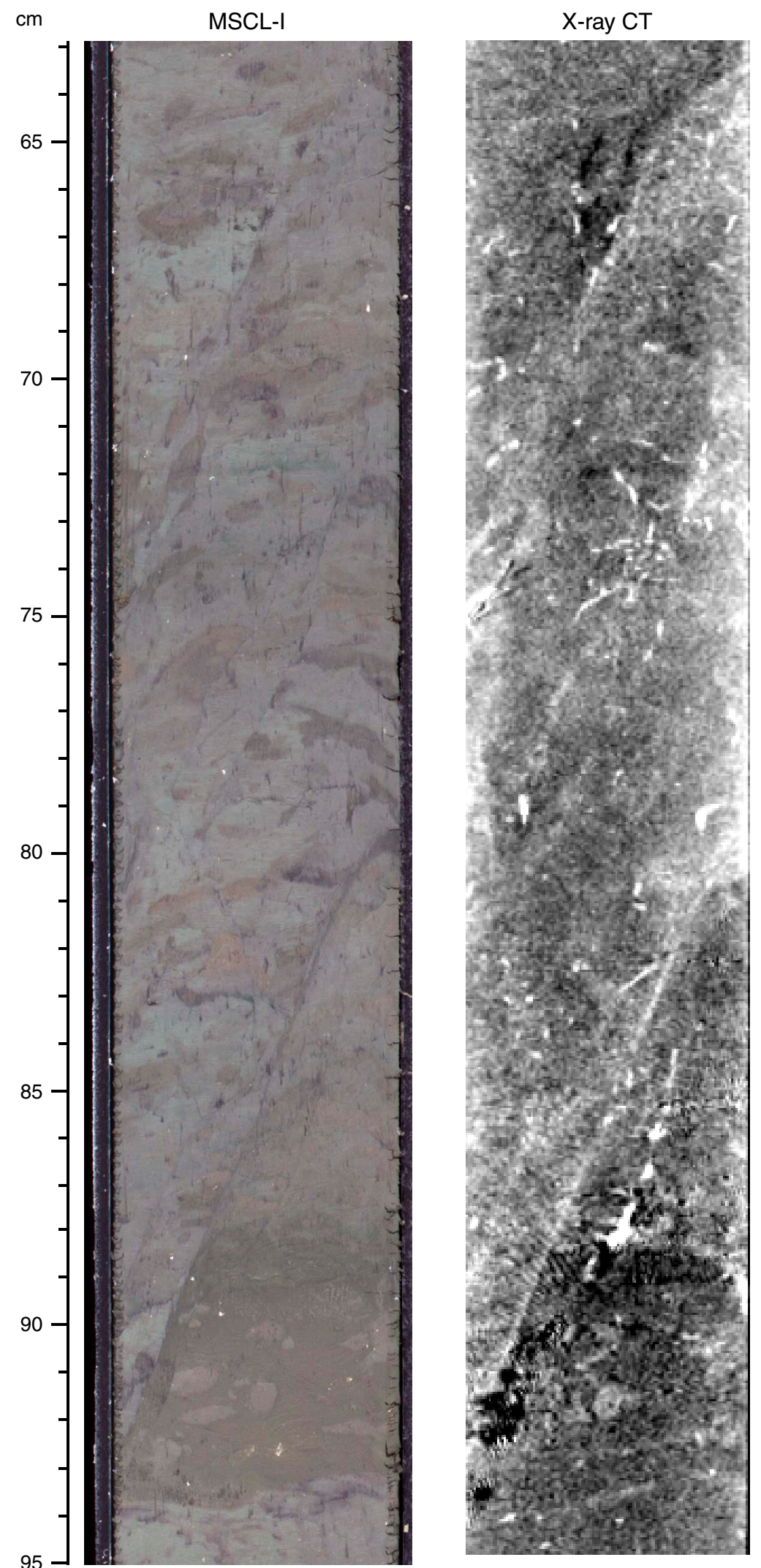


Figure F24. Mineral-filled veins in mud (interval 333-C0012D-11H-4, 70-90 cm). MSCL-I = photo image logger, $\mathrm{CT}=$ computed tomography.

$\mathrm{cm}$

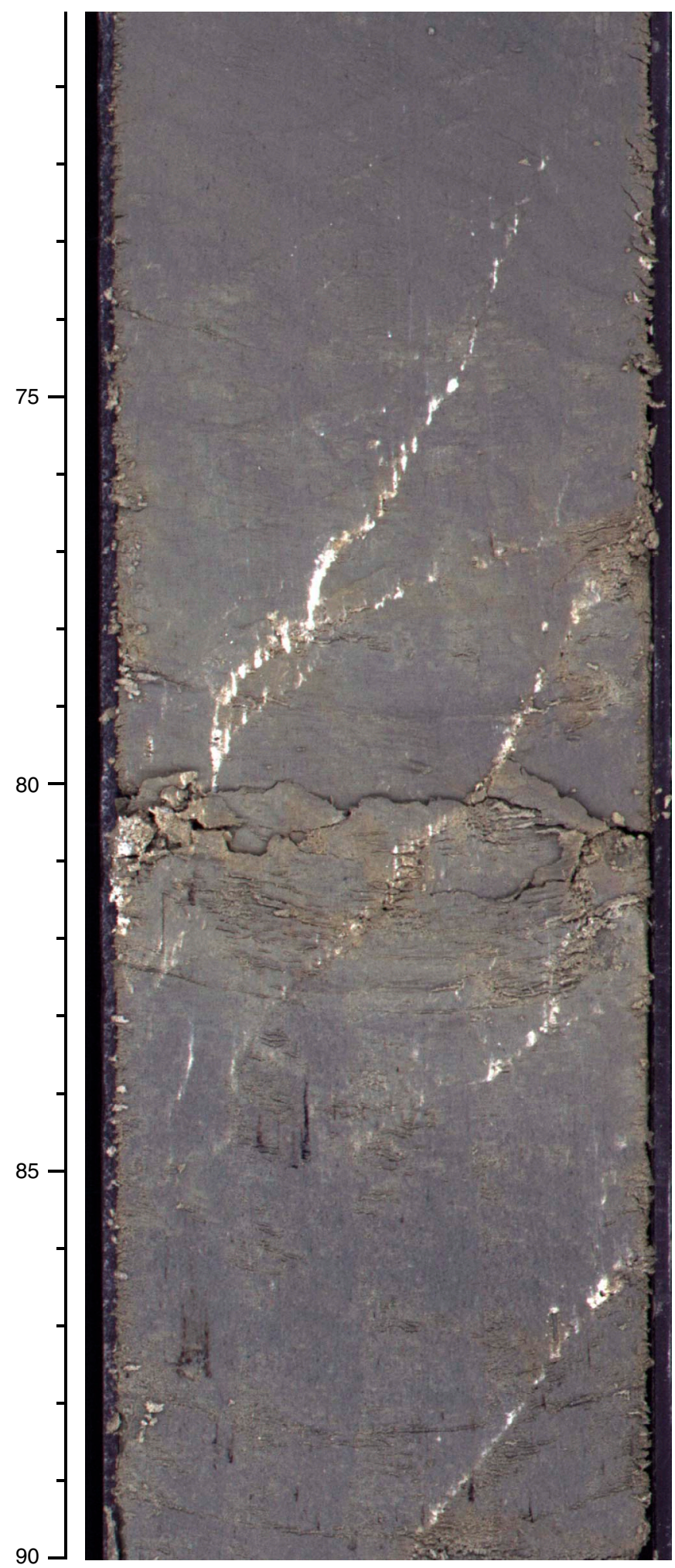

X-ray CT

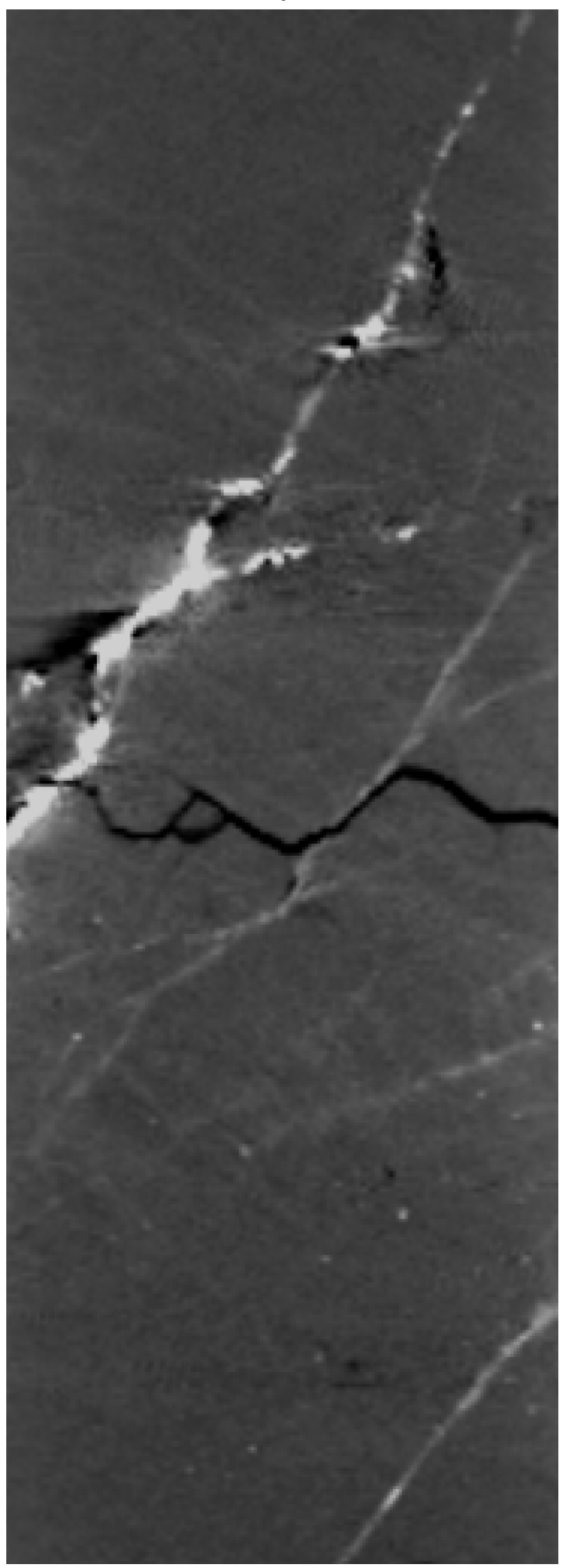


Figure F25. Geologic age vs. depth charts indicating sedimentation rate, Site C0012. Expedition 322 magnetostratigraphy Model A for the overlapped interval agrees with Expedition 333 age model. A. Age-depth diagram showing sedimentation rate based on apparent thickness of bedding. B. Age-true thickness diagram indicating sedimentation rate after correction for bedding dip.

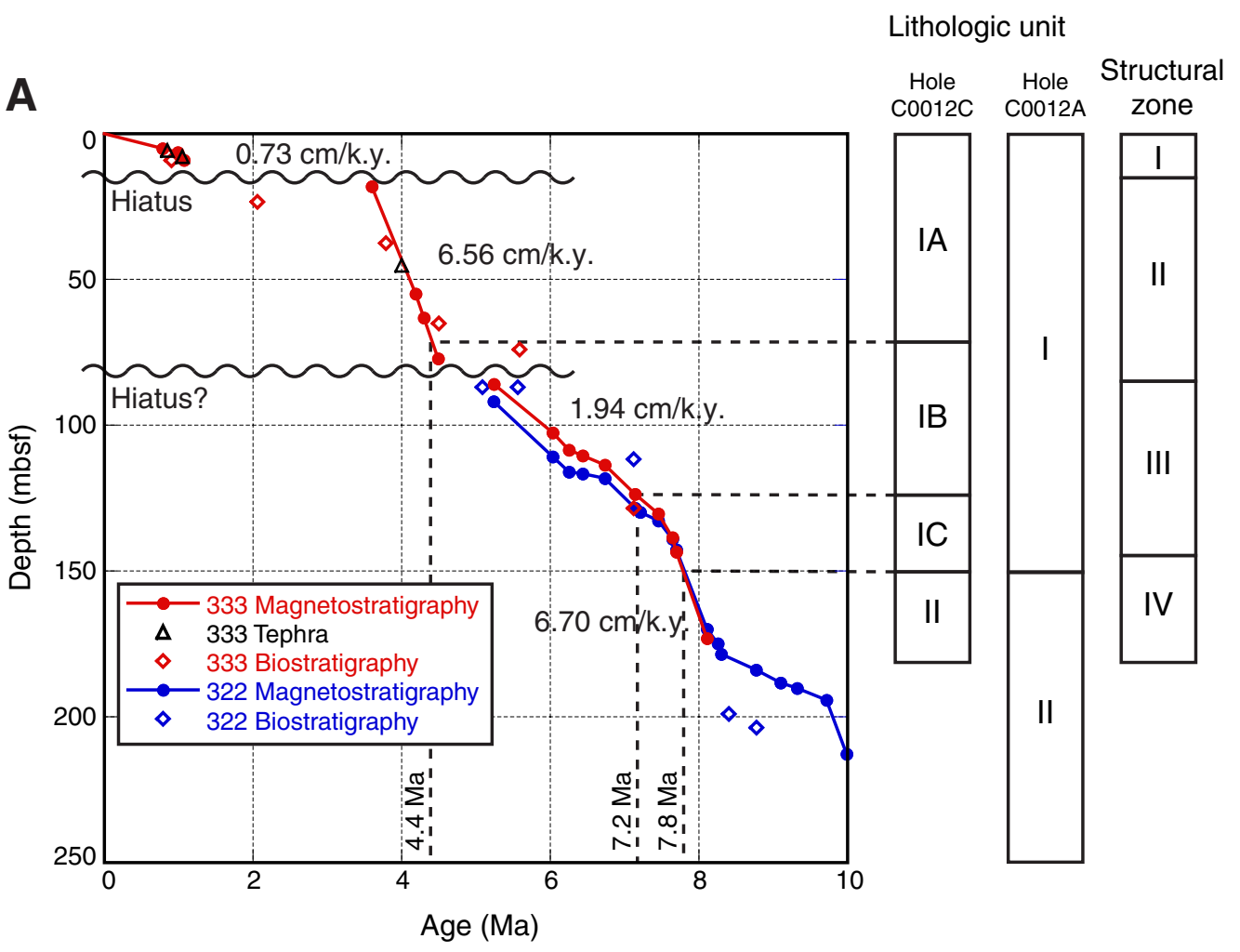

B

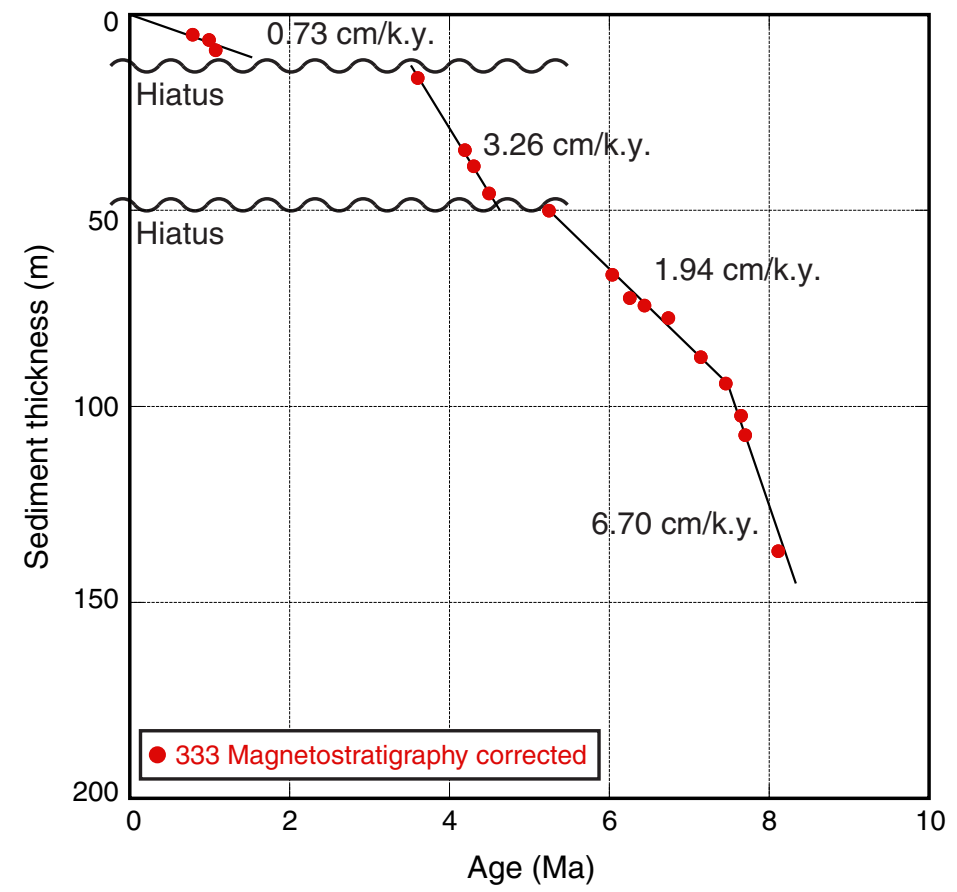


Figure F26. A. Lower hemisphere equal area projection of bedding, Holes C0012E and C0012G (great circle). B. Lower hemisphere equal area projection of mineral veins, Holes C0012E and C0012G (great circle).

A

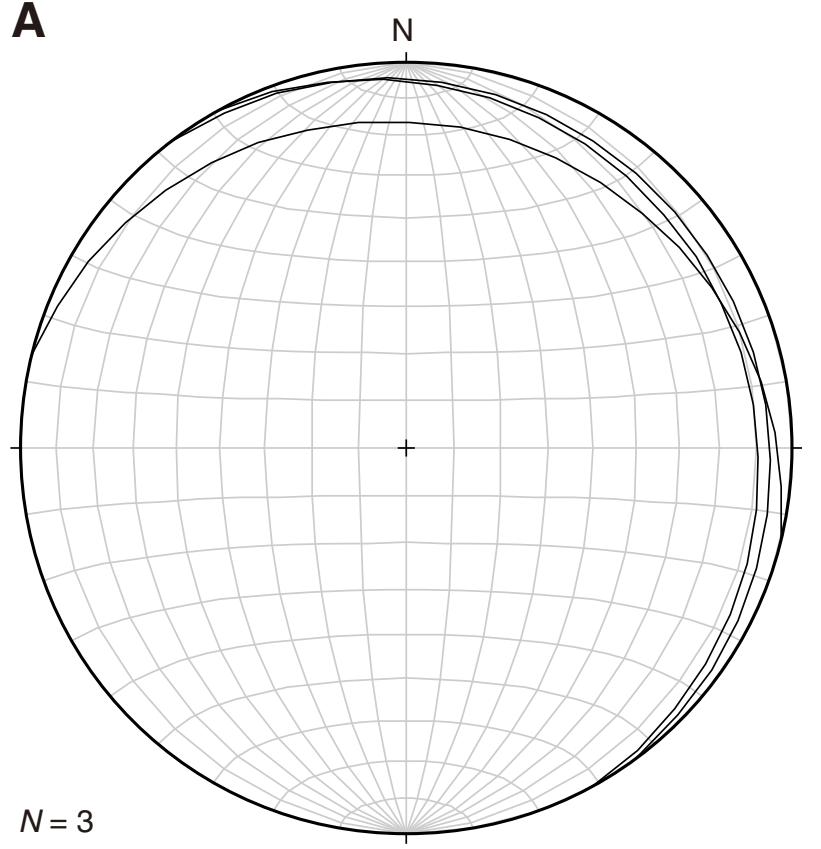

B

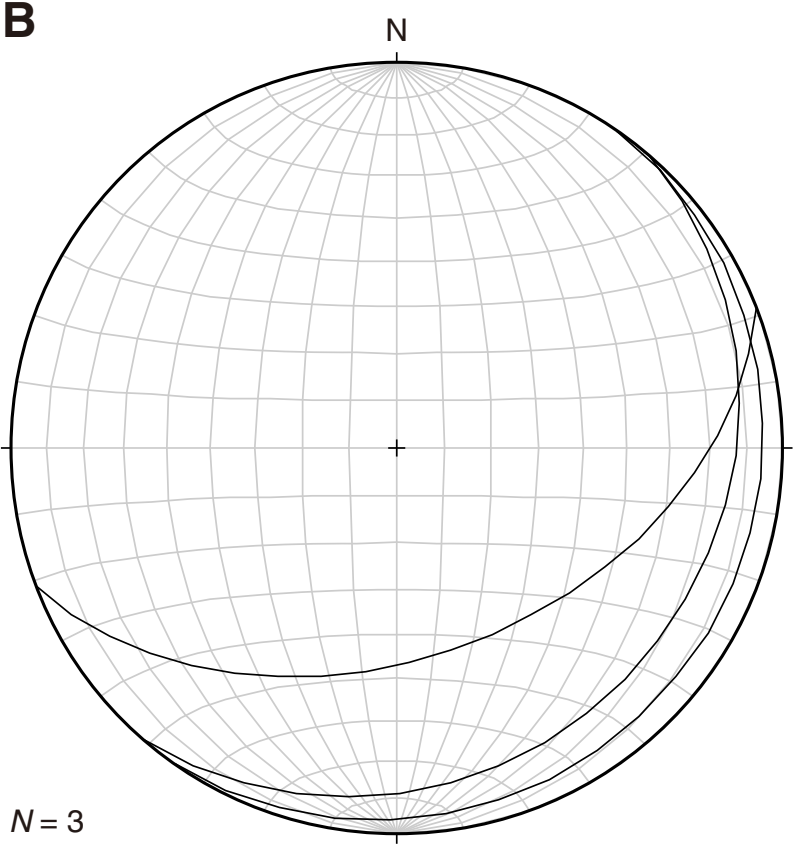


Figure F27. Appearance of sand dike in silty claystone (interval 333-C0012E-1X-1, 35-38 cm). Red triangles = location of sand dike.

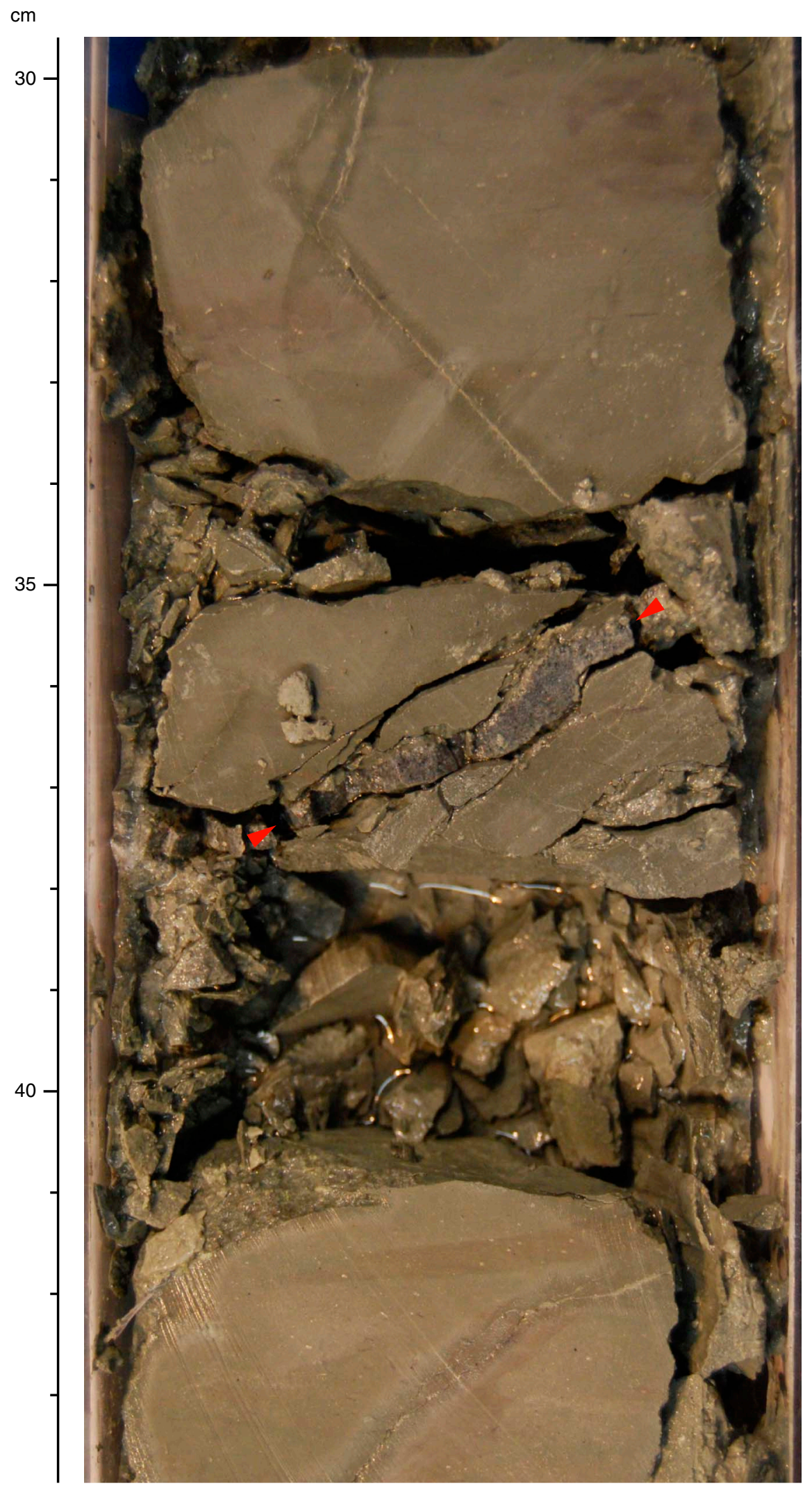


Figure F28. Age-depth plot for Holes C0012C and C0012D showing nannofossil datums, paleomagnetic events, and volcanic marker events. Sedimentation rates are indicated in the curve.

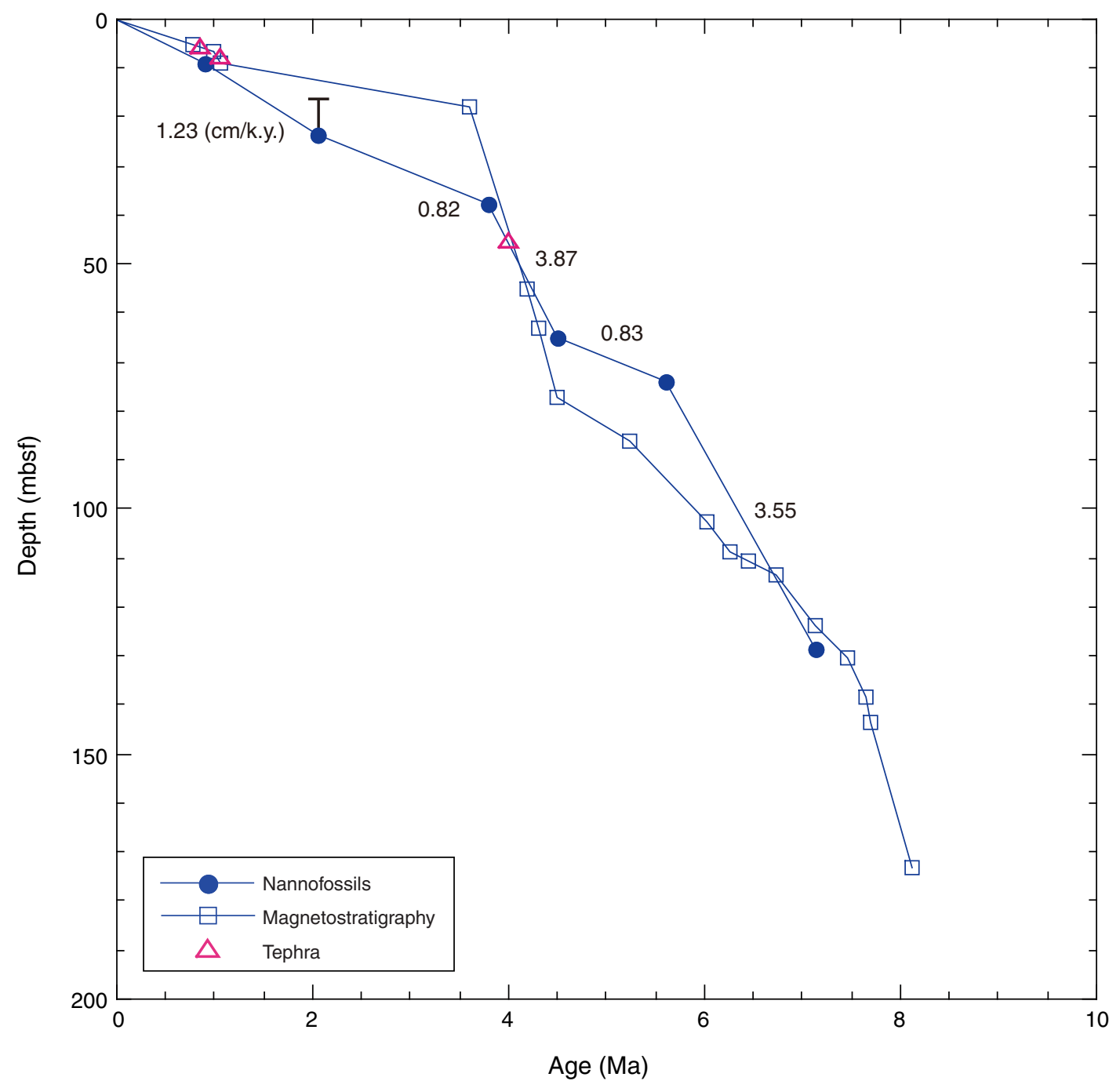


Figure F29. Natural remanent magnetization (green) and remanent magnetization after $30 \mathrm{mT}$ AF demagnetization (blue) as a function of depth, Holes C0012C and C0012D. Inclination values are uncorrected for bedding dip and are highly variable. Red straight lines $=$ tephra layer, red wavy lines $=$ possible hiatus, red dashed line $=$ possible age reversal due to chaotic interval, star $=$ fossil occurrence indicating $\sim 1$ Ma .
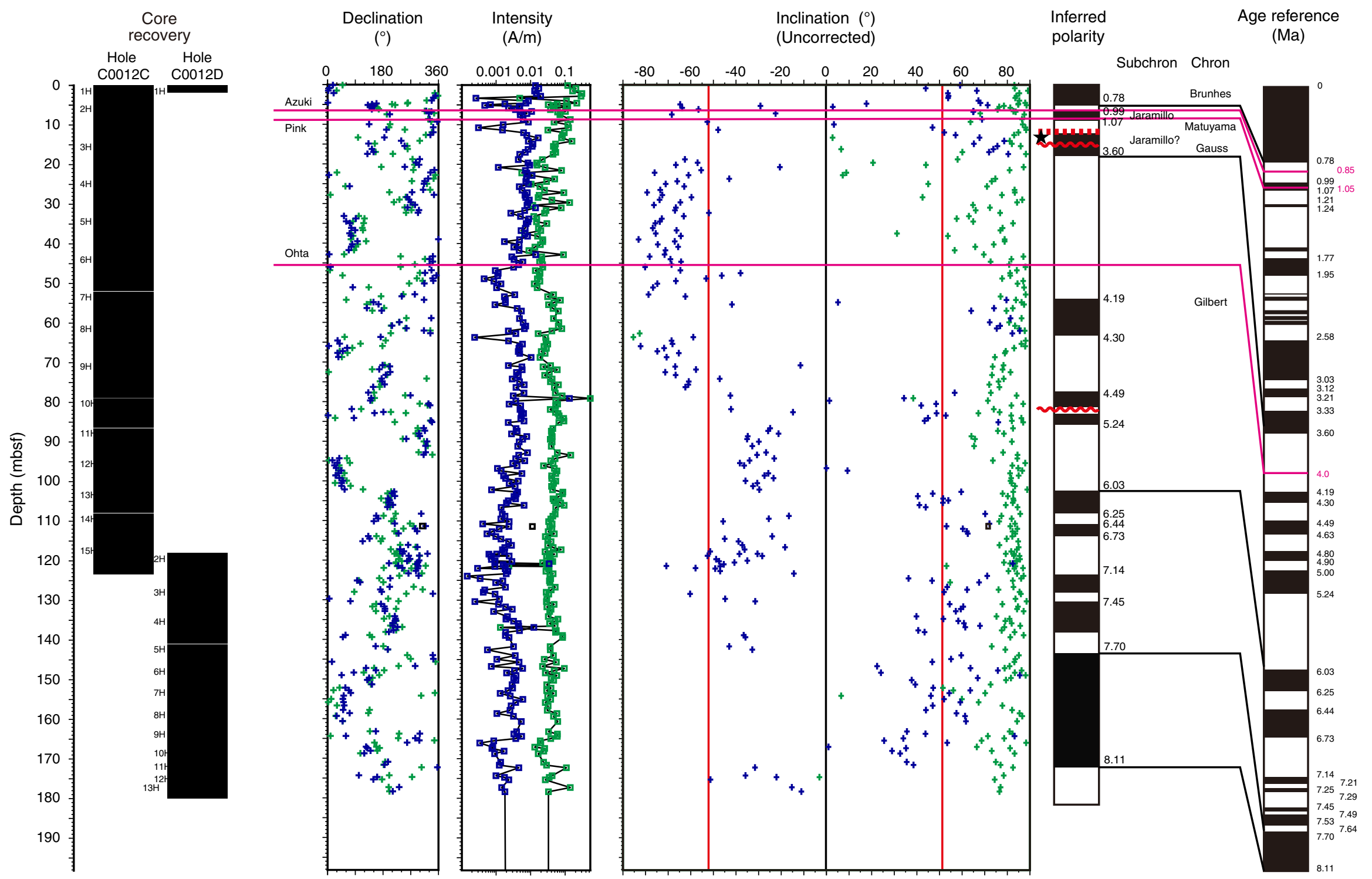
Figure F30. Inclination data after $30 \mathrm{mT}$ AF demagnetization before and after bedding correction, Site C0012. Prior to bedding correction, inclination values are highly variable, but following bedding correction, data are more clustered around the expected value of $\pm 52^{\circ}$ (red lines). Chron and subchron boundaries are not affected by bedding correction.

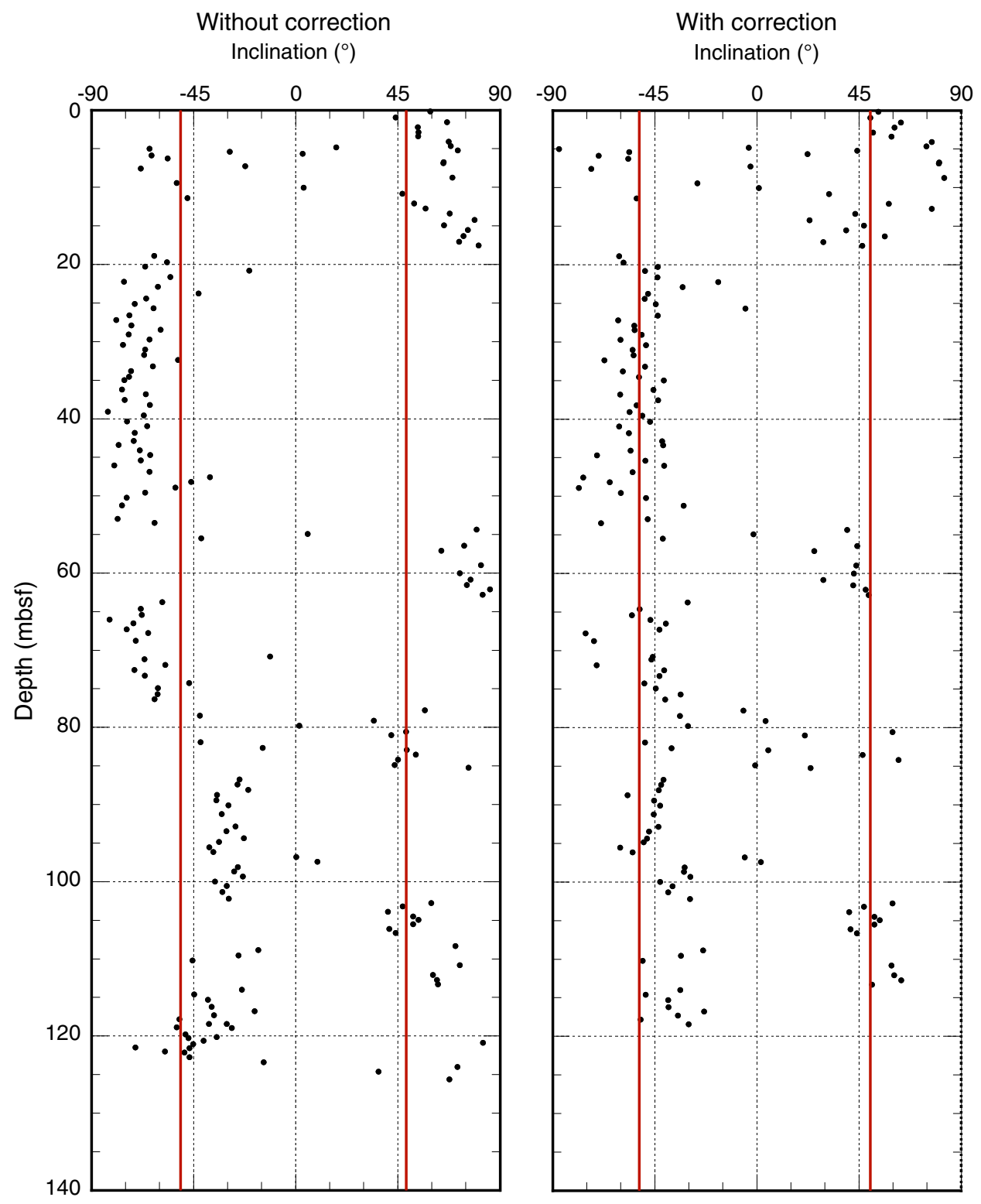


Figure F31. Magnetic susceptibility correlation between Sites C0011 and C0012. Black dashed lines $=$ chron and subchron correlations, purple $=$ volcanic ash bed correlations, red wavy line $=$ hiatus, red dashed line $=$ possible age reversal due to chaotic interval, green box $=\sim 80 \mathrm{~m}$ section that is missing from Site C0012.

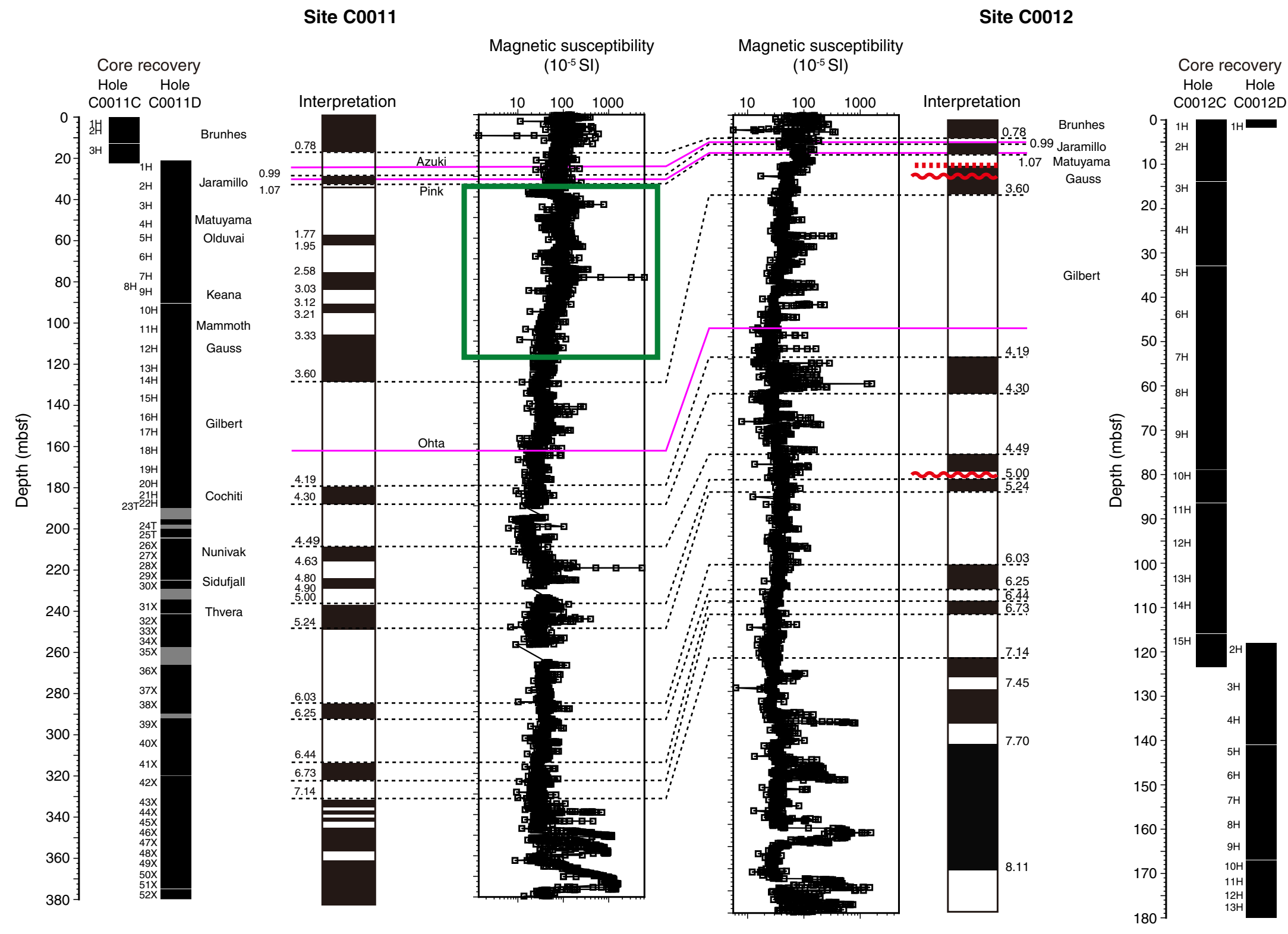


Figure F32. Natural remanent magnetization (NRM) and remanent magnetization after $30 \mathrm{mT}$ AF demagnetization as a function of depth, Holes C0012E, C0012F, and C0012G.

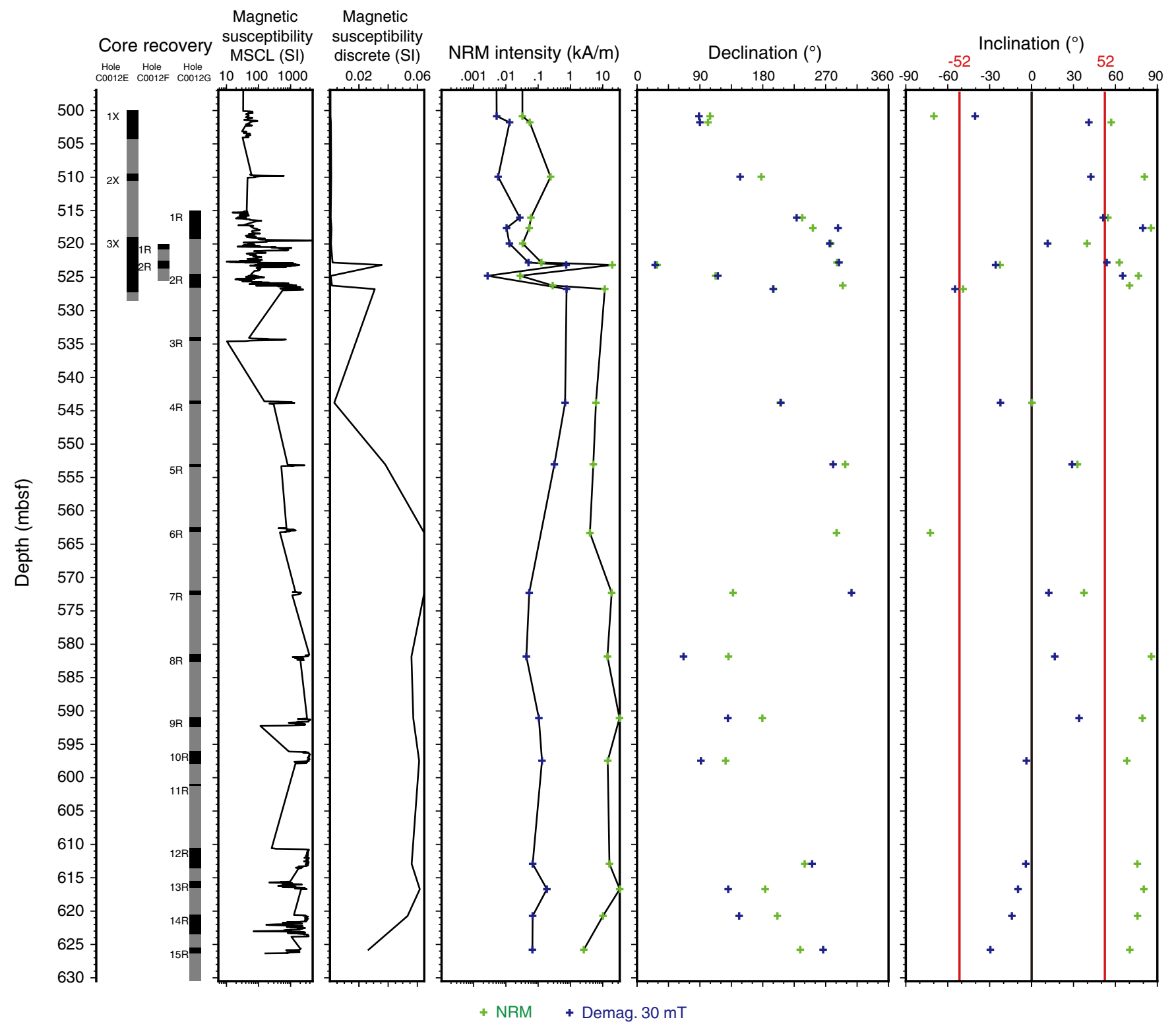


Figure F33. Site C0012 gamma ray attenuation (GRA) density, magnetic susceptibility, noncontact electrical resistivity, and natural gamma radiation determined by MSCL-W with lithology. $\mathrm{CMS}=$ corrected volume magnetic susceptibility, $\mathrm{cps}=$ counts per second, $\mathrm{TD}=$ total depth. $\mathrm{Black}=$ Holes C0012C, C0012D, and C0012E, red = Expedition 322 Holes C0012A and C0012B.

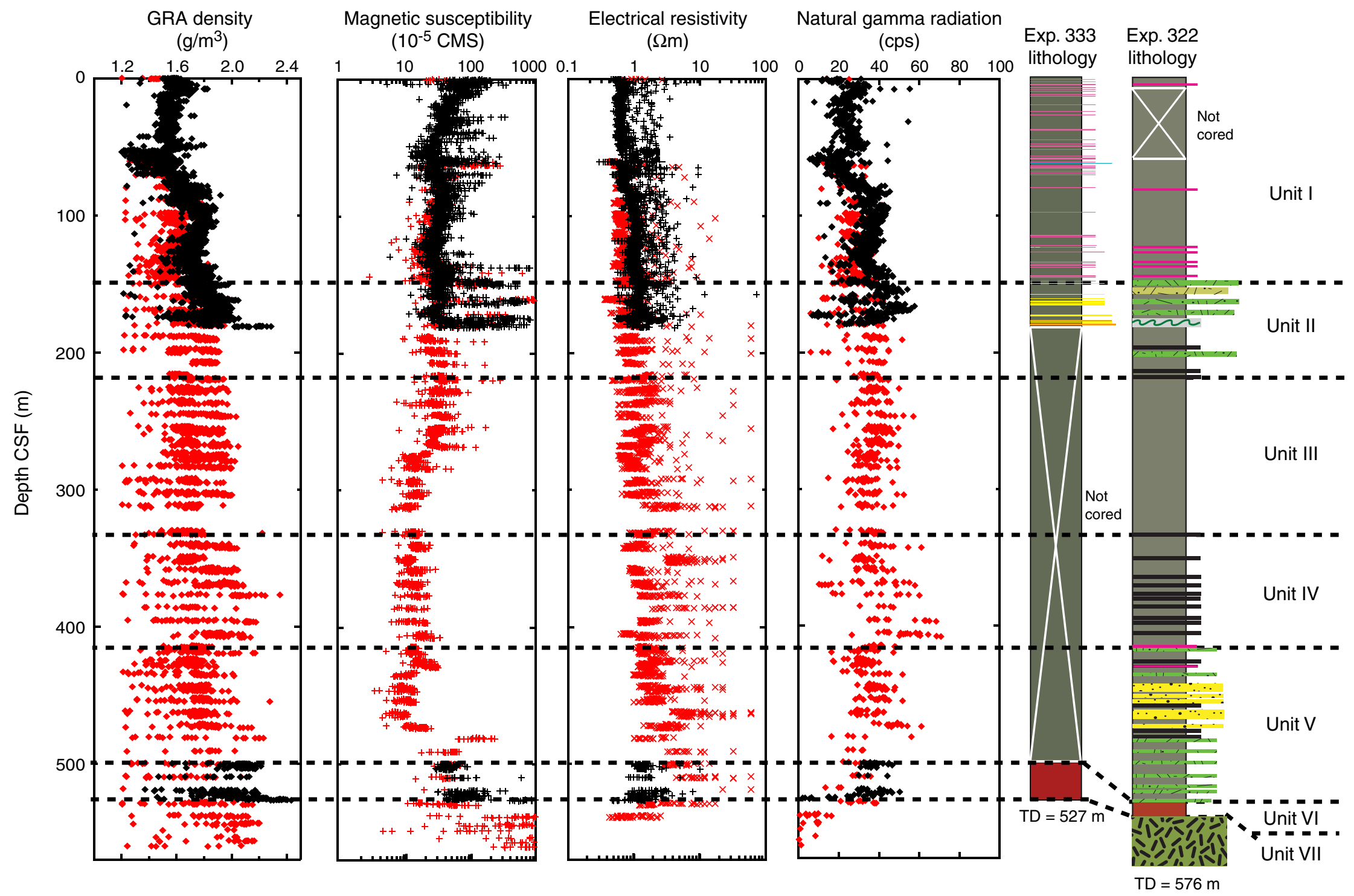


Figure F34. Bulk density, porosity, and grain density data, Site C0012. Filled symbols = Holes C0012C, C0012D, and C0012E, open symbols = Expedition 322 Hole C0012B, red $=$ sand or ash, light blue $=$ Holes C0012E, C0012F, and C0012G basalts.

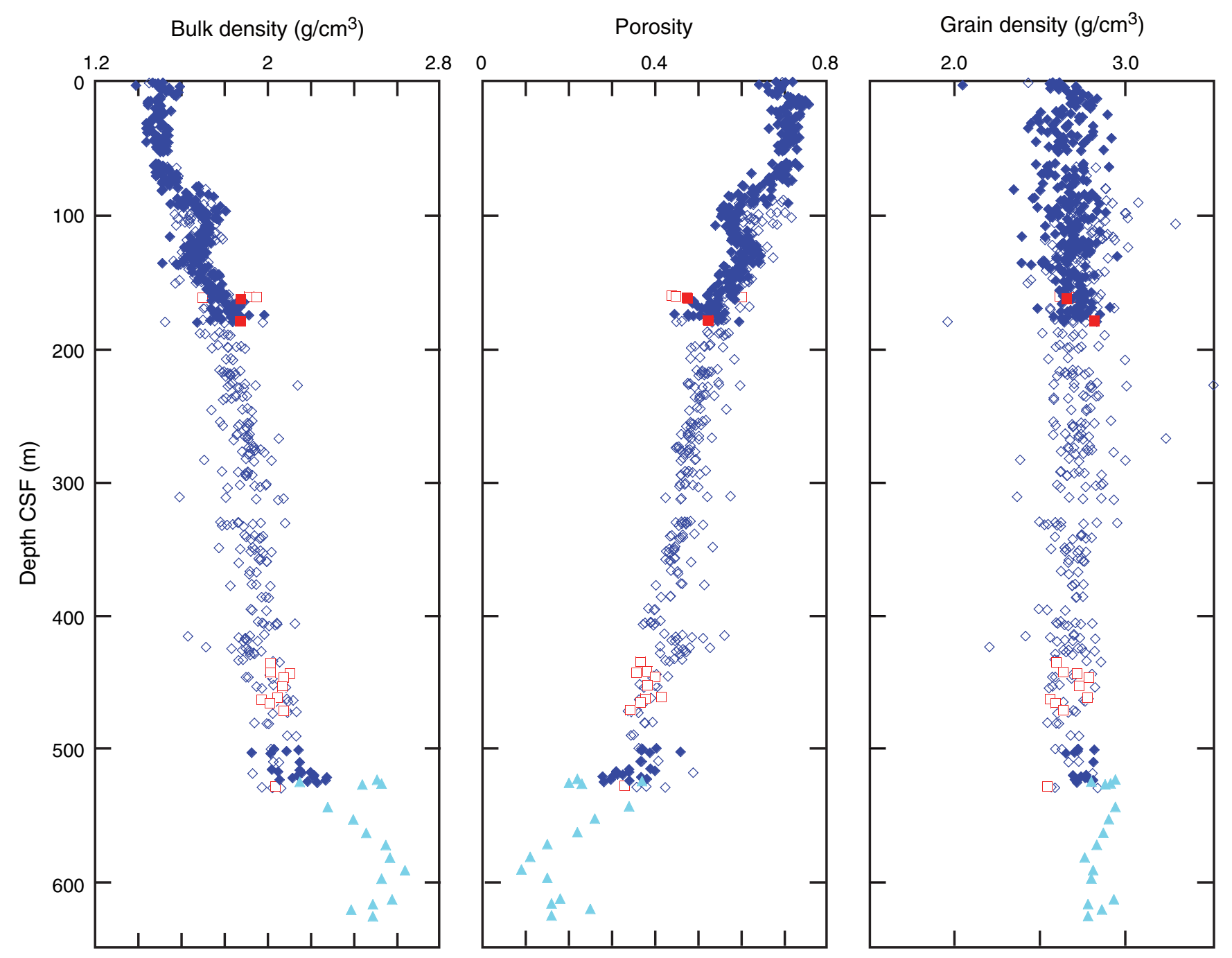


Figure F35. Porosity data from Site C0011 and C0012 mudstones.

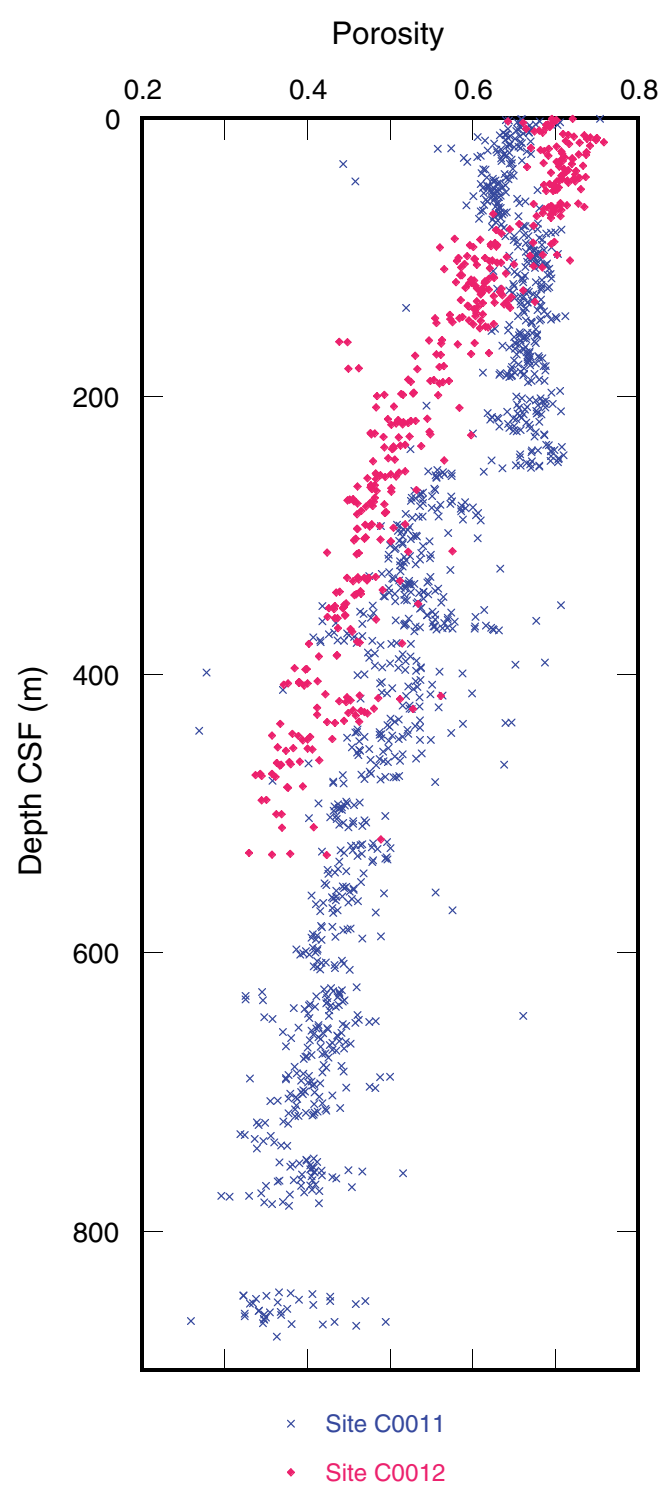


Figure F36. Strength provided by penetrometer and vane shear measurements from Site C0012 plotted with porosity from MAD measurements.

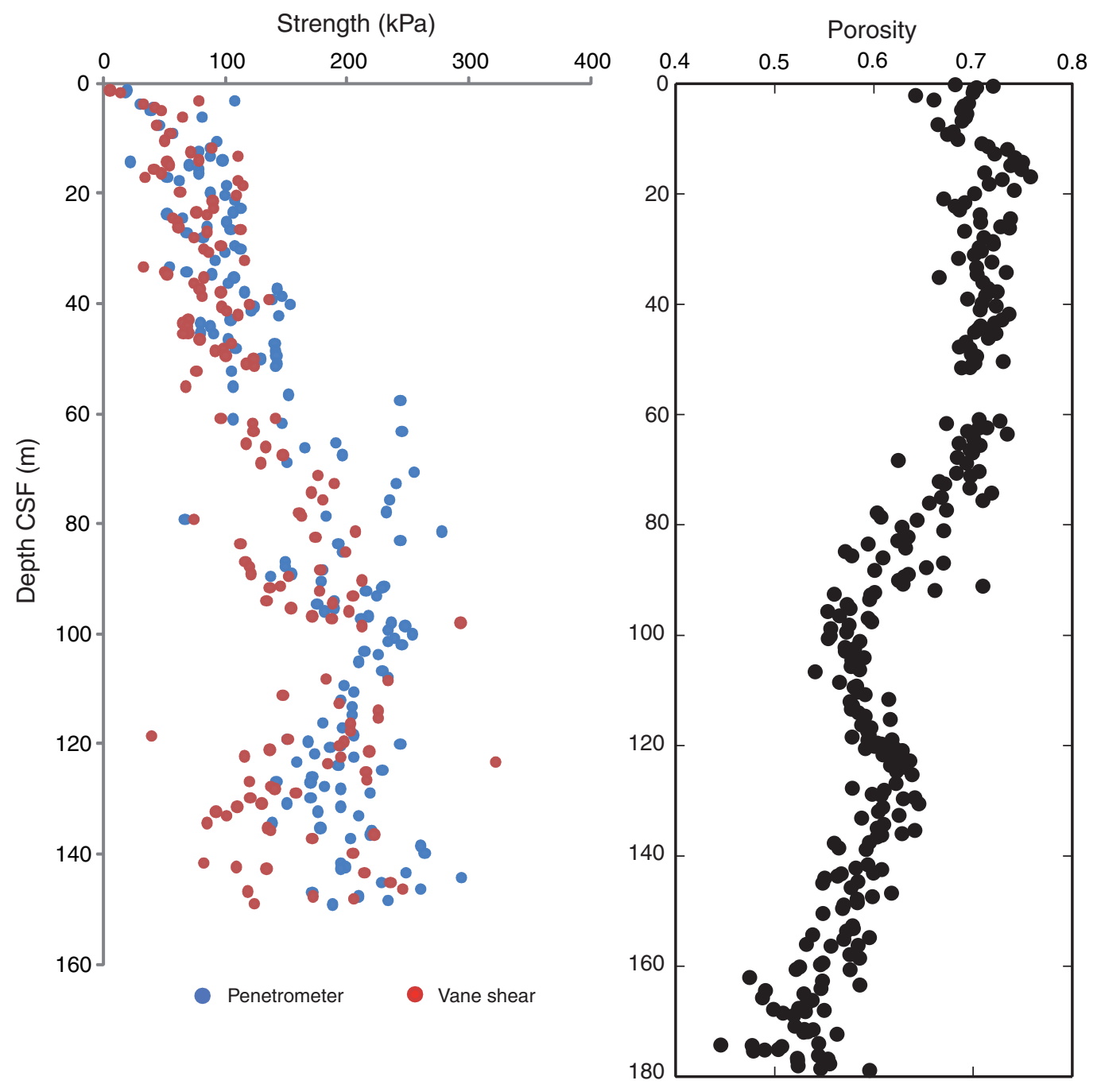


Figure F37. A. $P$-wave velocity in the $z$-direction measured on discrete samples, Site C0012. B. Vertical-plane anisotropy of $P$-wave velocity determined from measurements on discrete samples, Site C0012.

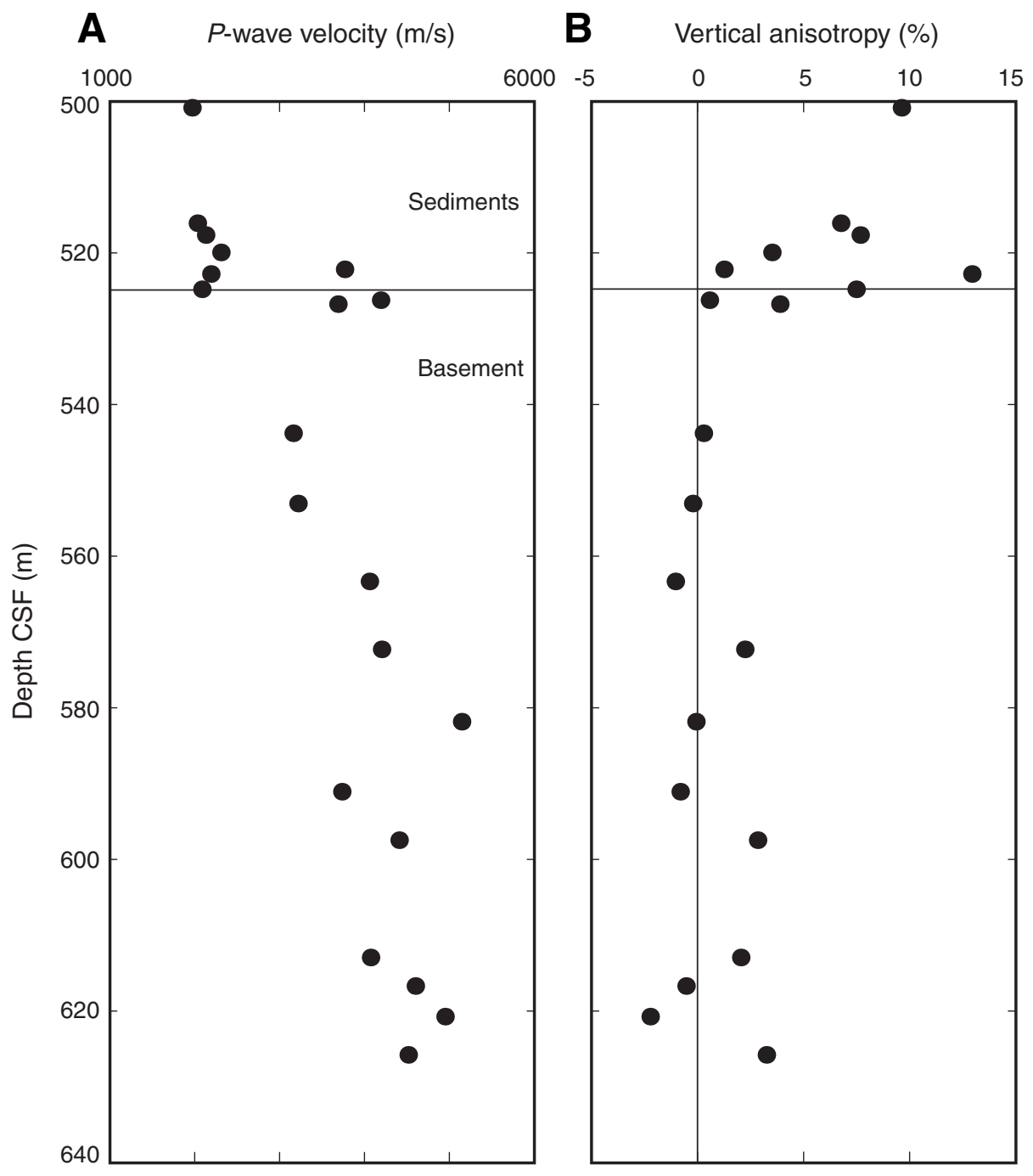


Figure F38. A. Measured resistivity plotted with multisensor core logger (MSCL) resistivity, Site C0012. B. Porosity derived from MAD measurements, Site C0012.

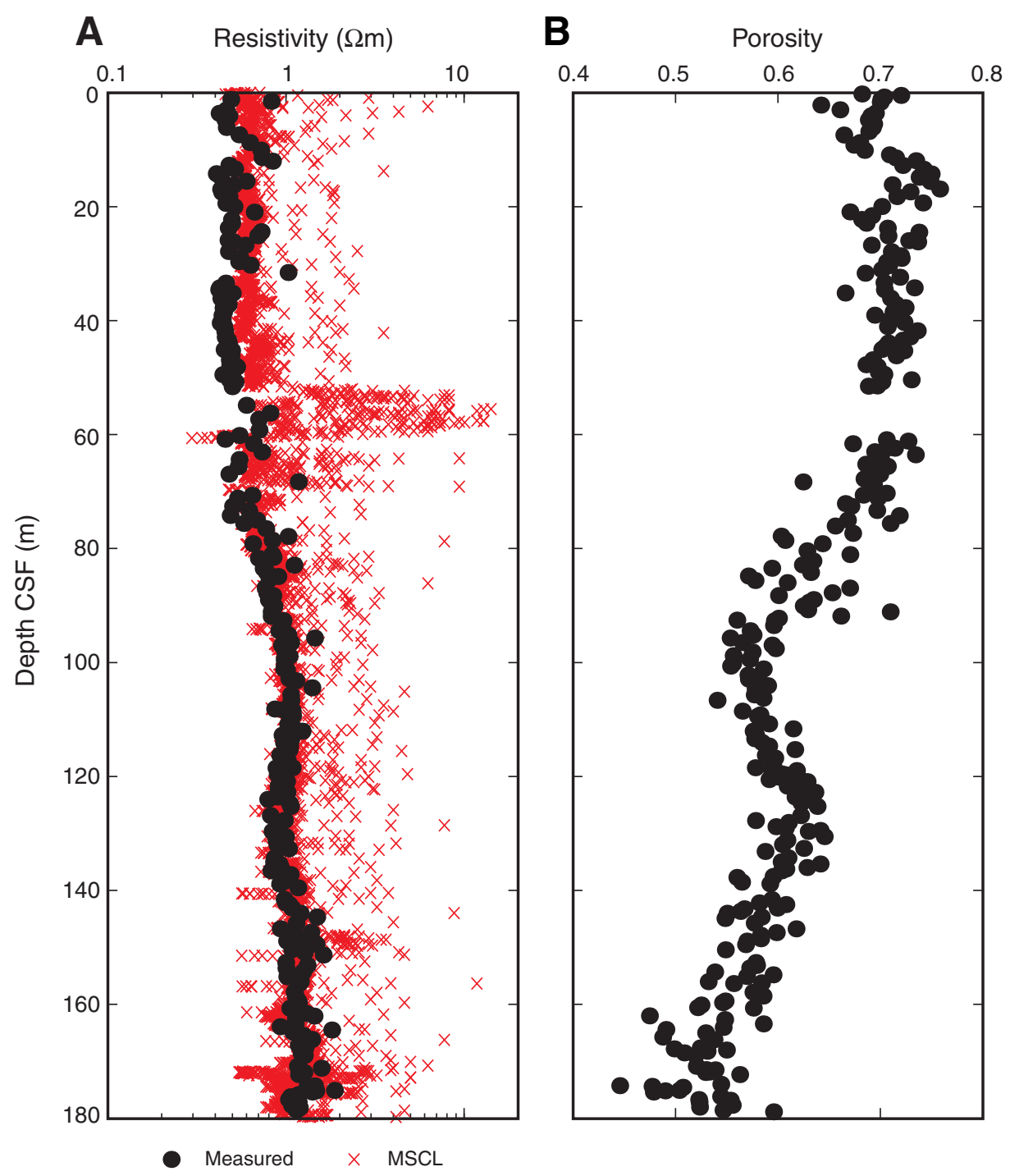


Figure F39. Measured resistivity data as a function of MAD-derived porosity, Site C0012. Red = anomalously high porosity data from 12 to $78 \mathrm{~m}$ CSF.

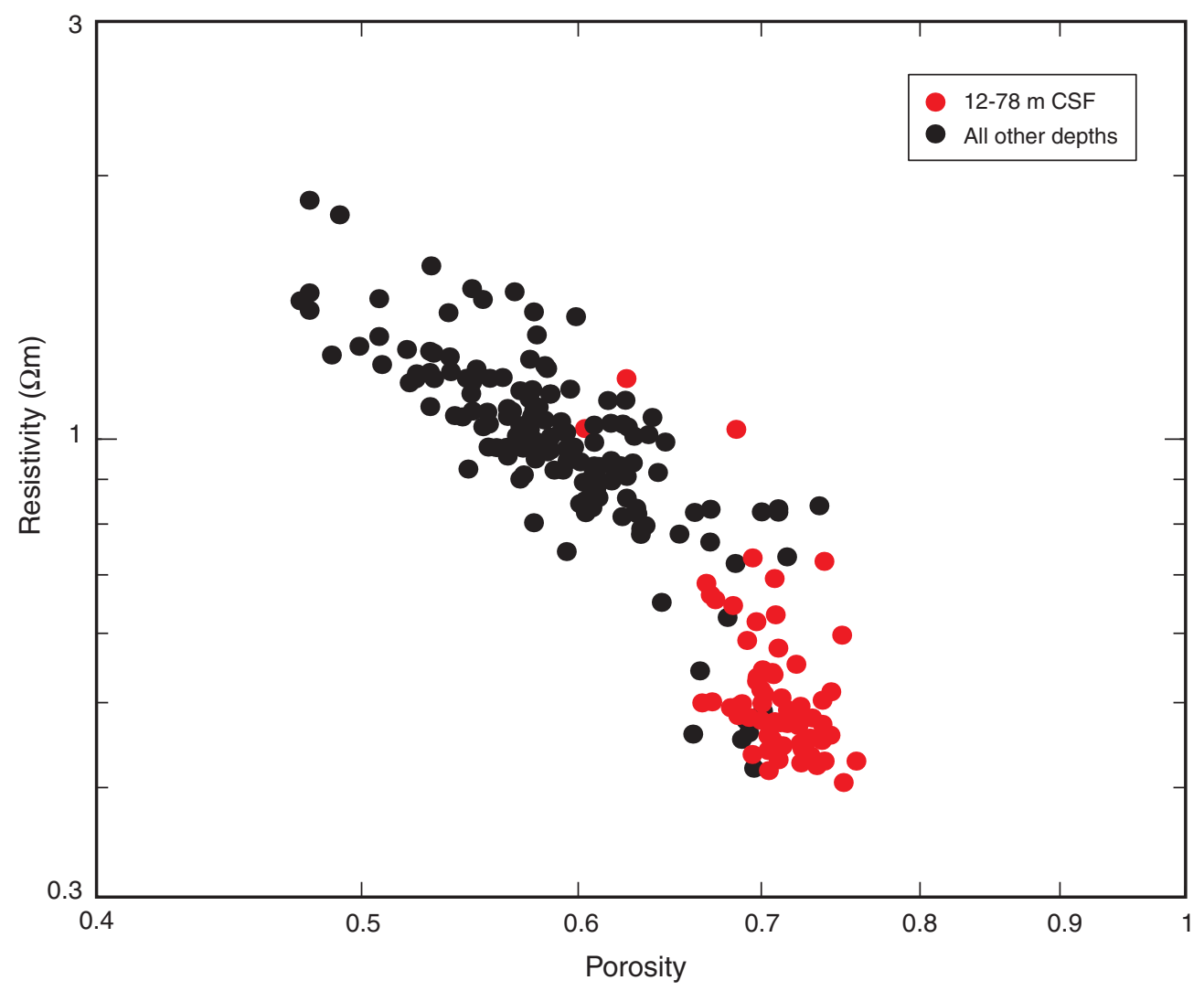


Figure F40. A. Resistivity in the $z$-direction measured on discrete samples, Site C0012. B. Vertical-plane anisotropy of resistivity determined from measurements on discrete samples, Site C0012. Open symbols = measurements $>10 \Omega \mathrm{m}$, which are very sensitive to the thickness of water films on sample surfaces and thus may be subject to greater uncertainty of both absolute value and anisotropy.

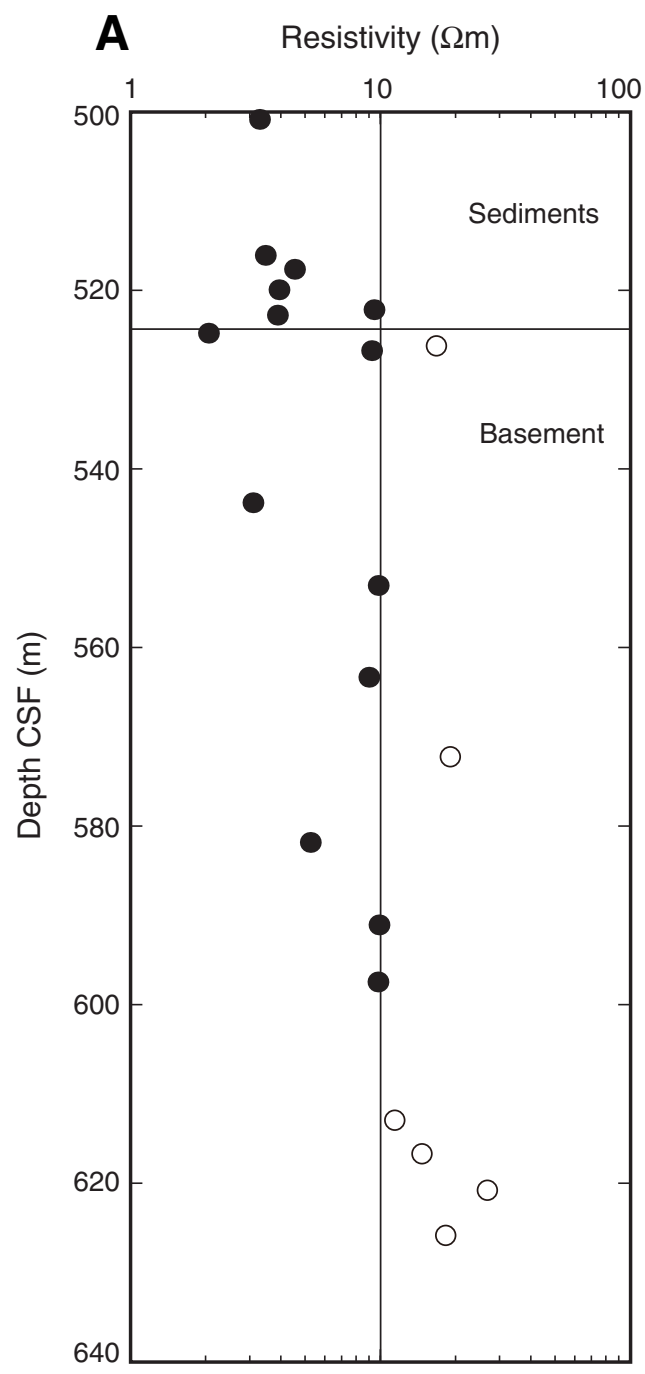

B Vertical anisotropy (\%)

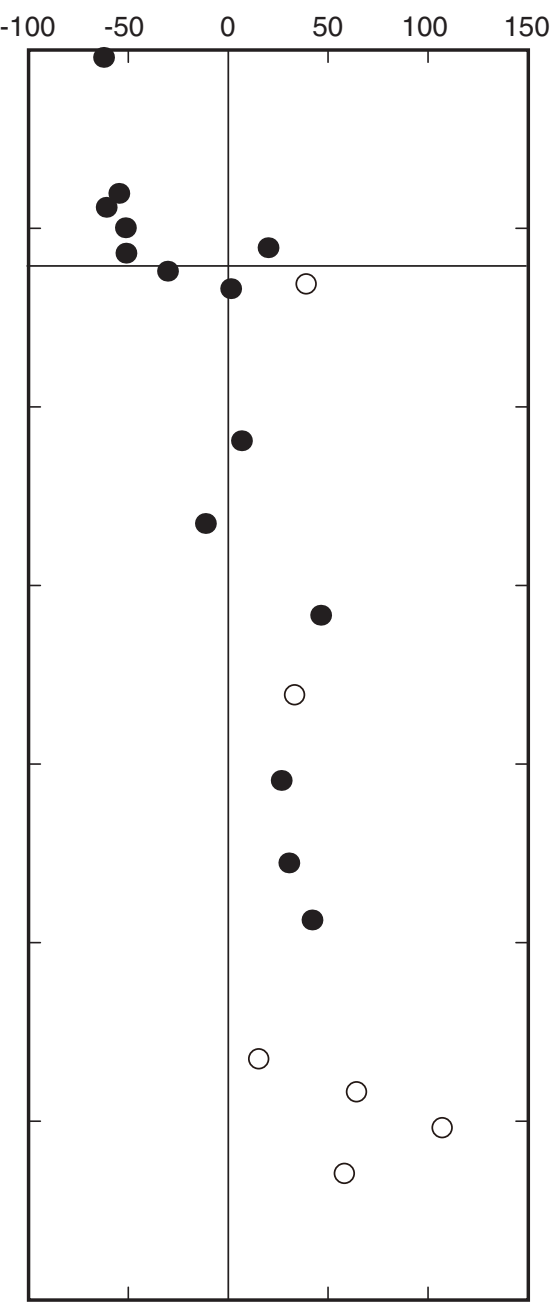


Figure F41. Measured thermal conductivity as a function of depth, Holes C0012C and C0012D. Thermal conductivity $(\mathrm{W} /[\mathrm{m} \cdot \mathrm{K}])$

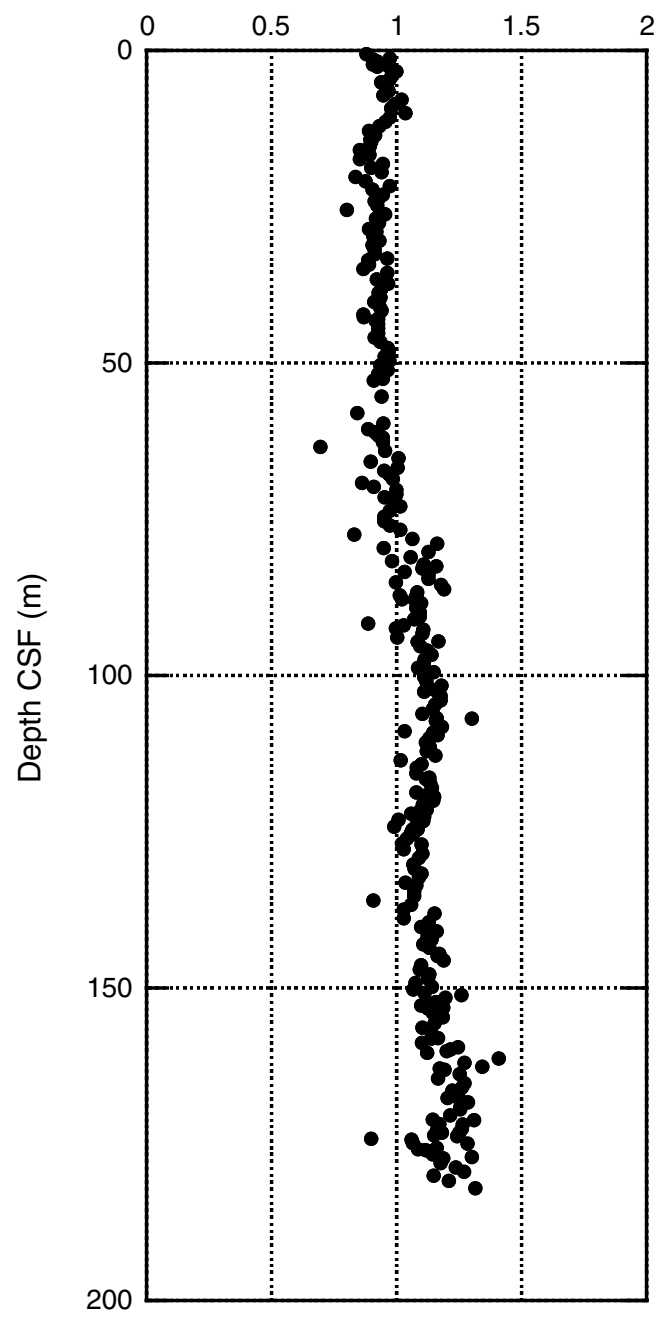


Figure F42. Temperatures measured using the APCT-3, Holes C0012C and C0012D. Average thermal gradient of $135^{\circ} \mathrm{C} / \mathrm{km}$ and intercept temperature of $2.85^{\circ} \mathrm{C}$ at seafloor are obtained by least squares fit.

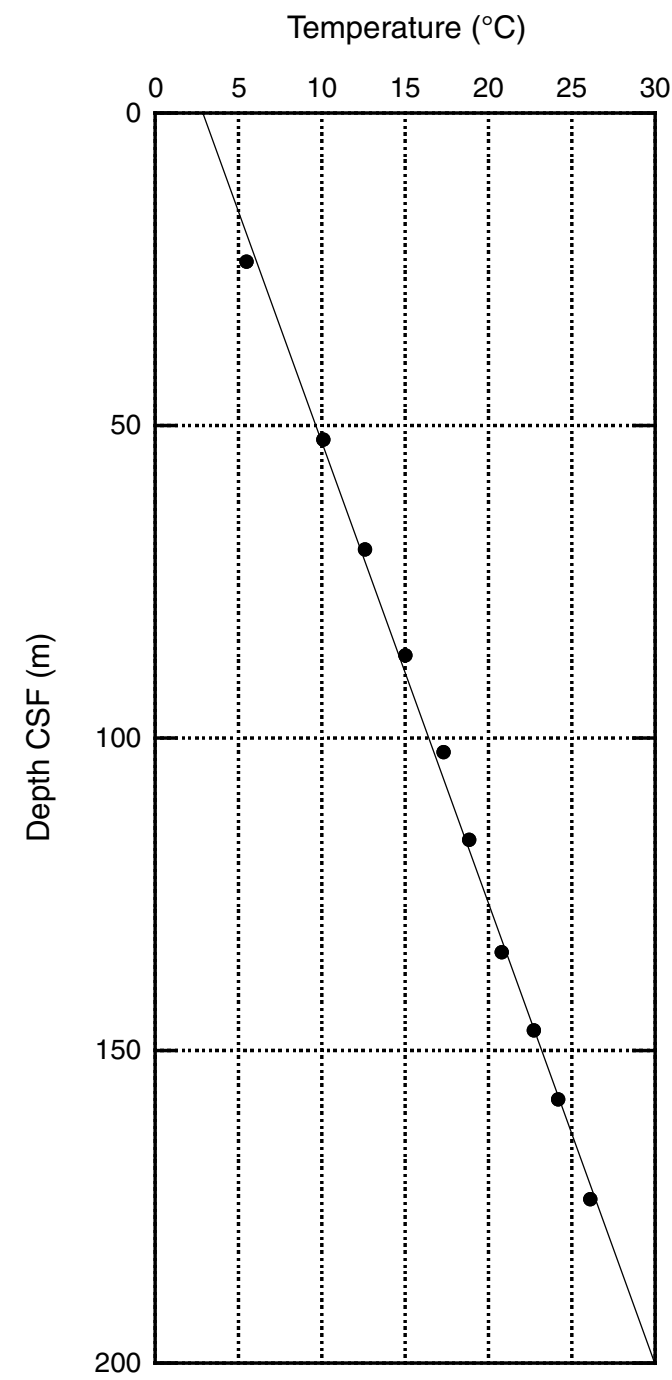


Figure F43. Synthesized temperature vs. depth curve at Site C0012 for the depths below temperature measurements $(<173.5 \mathrm{~m} \mathrm{CSF})$, with an assumption of purely conductive thermal regime from the seafloor to the top of basaltic basement. Estimated temperatures are based on calculated heat flow value and all measured thermal conductivity below $173.5 \mathrm{mbsf}$. Temperature at top of basement is estimated to be $\sim 64^{\circ} \mathrm{C}$.

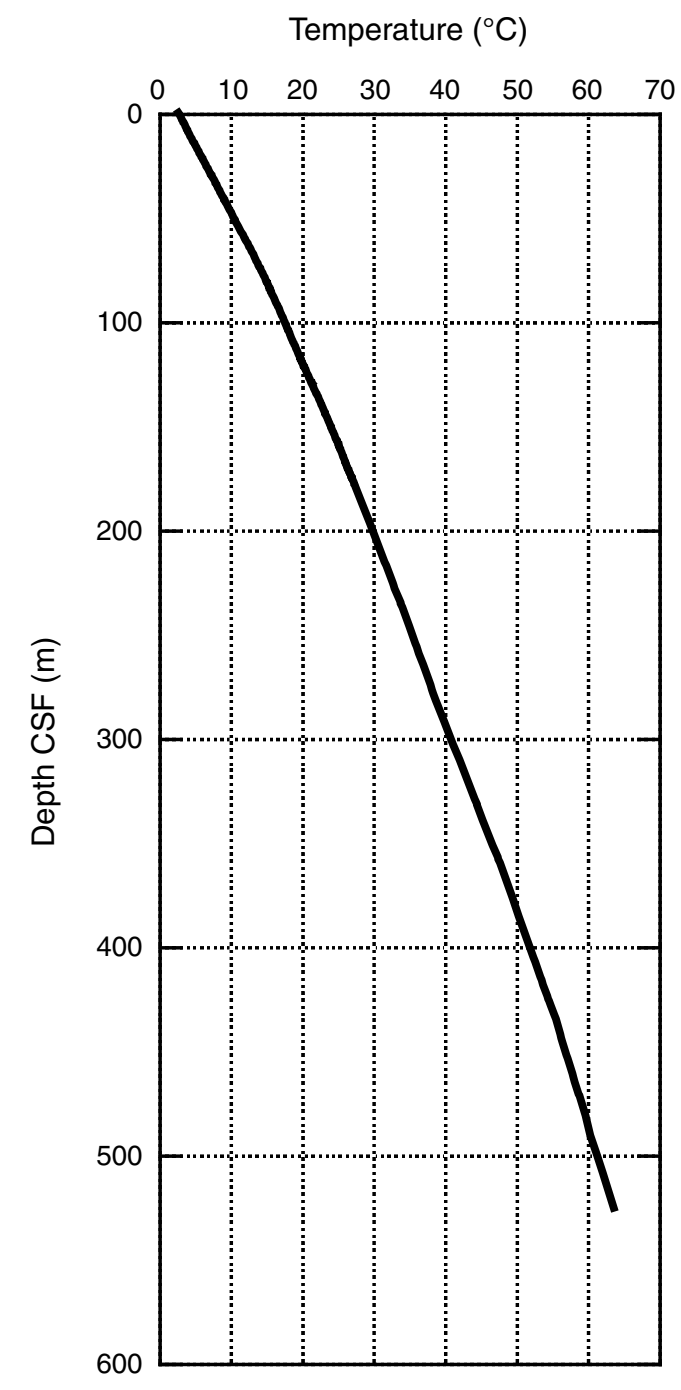


Figure F44. Thermal conductivity data plotted as a function of depths >500 m CSF (basement), Site C0012. Thermal conductivity $(\mathrm{W} /[\mathrm{m} \cdot \mathrm{K}])$

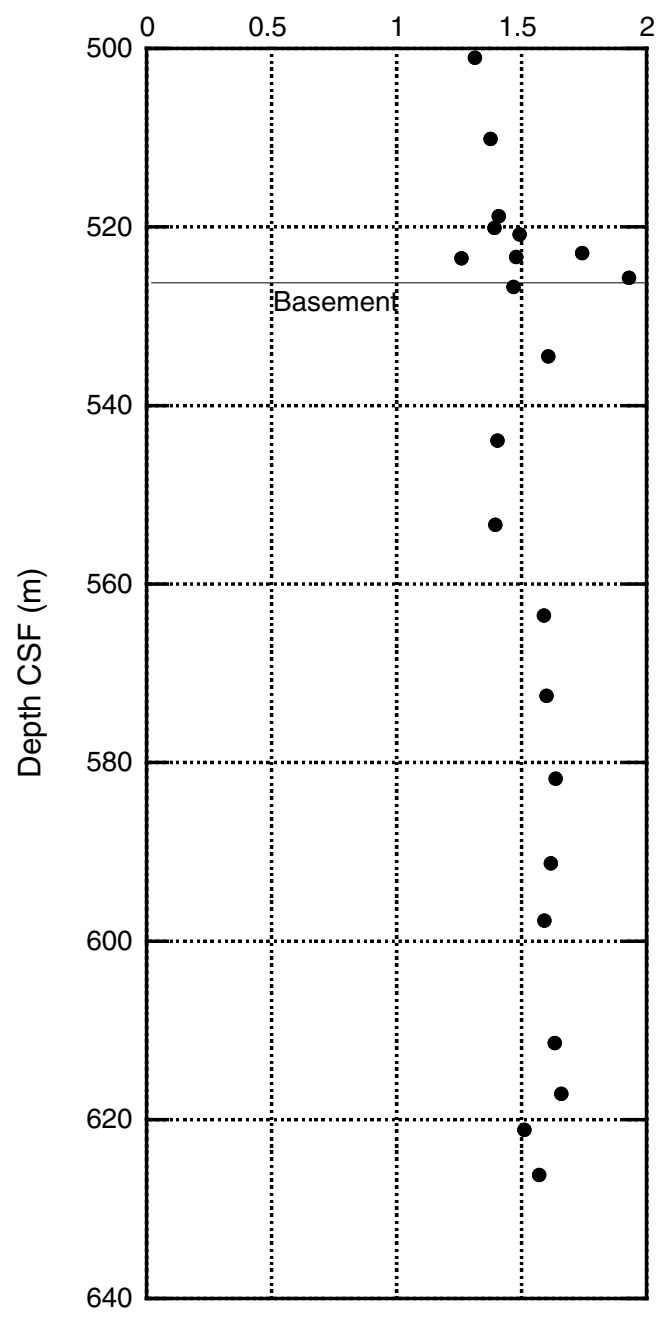


Figure F45. A. Volume of interstitial water (IW) recovered per length of IW whole-round section (mL/cm). Red $=$ Holes C0012C and C0012D, blue $=$ Expedition 322 Hole C0012A (Expedition 322 Scientists, 2010; fig. F48). B. Dissolved sulfate profile. Red = Holes C0012C, C0012D, C0012E, and C0012G; blue = Expedition 322 Hole C0012A (Expedition 322 Scientists, 2010; table T20).

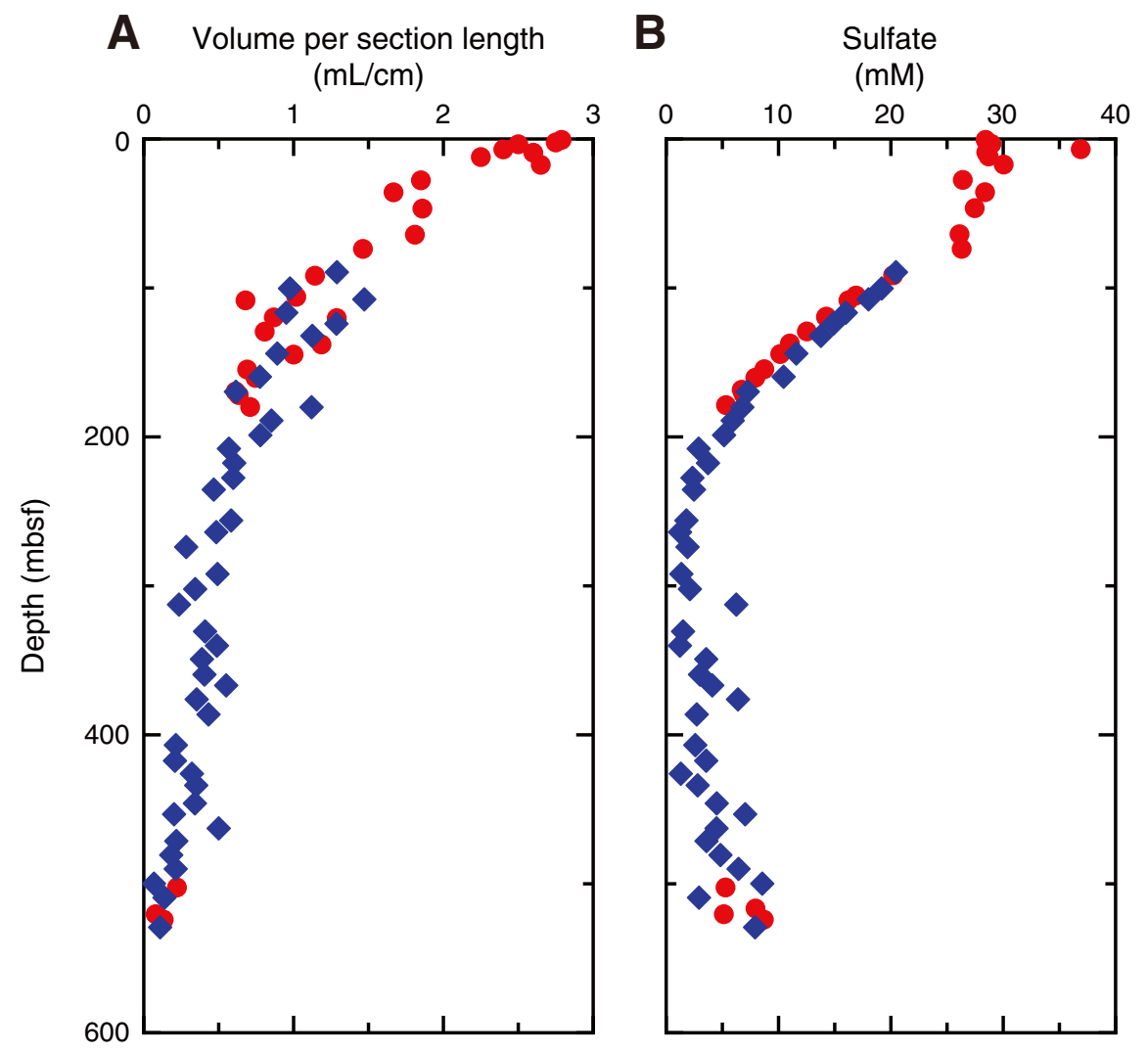


Figure F46. Interstitial water constituents (salinity, chlorinity, bromide, $\mathrm{pH}$, alkalinity, sodium, ammonium, $\mathrm{phosphate,} \mathrm{Br} / \mathrm{Cl}$, and boron). Red $=$ Holes C0012C, C0012D, C0012E, and C0012G; blue = Expedition 322 Hole C0012A (Expedition 322 Scientists, 2010; table T20).
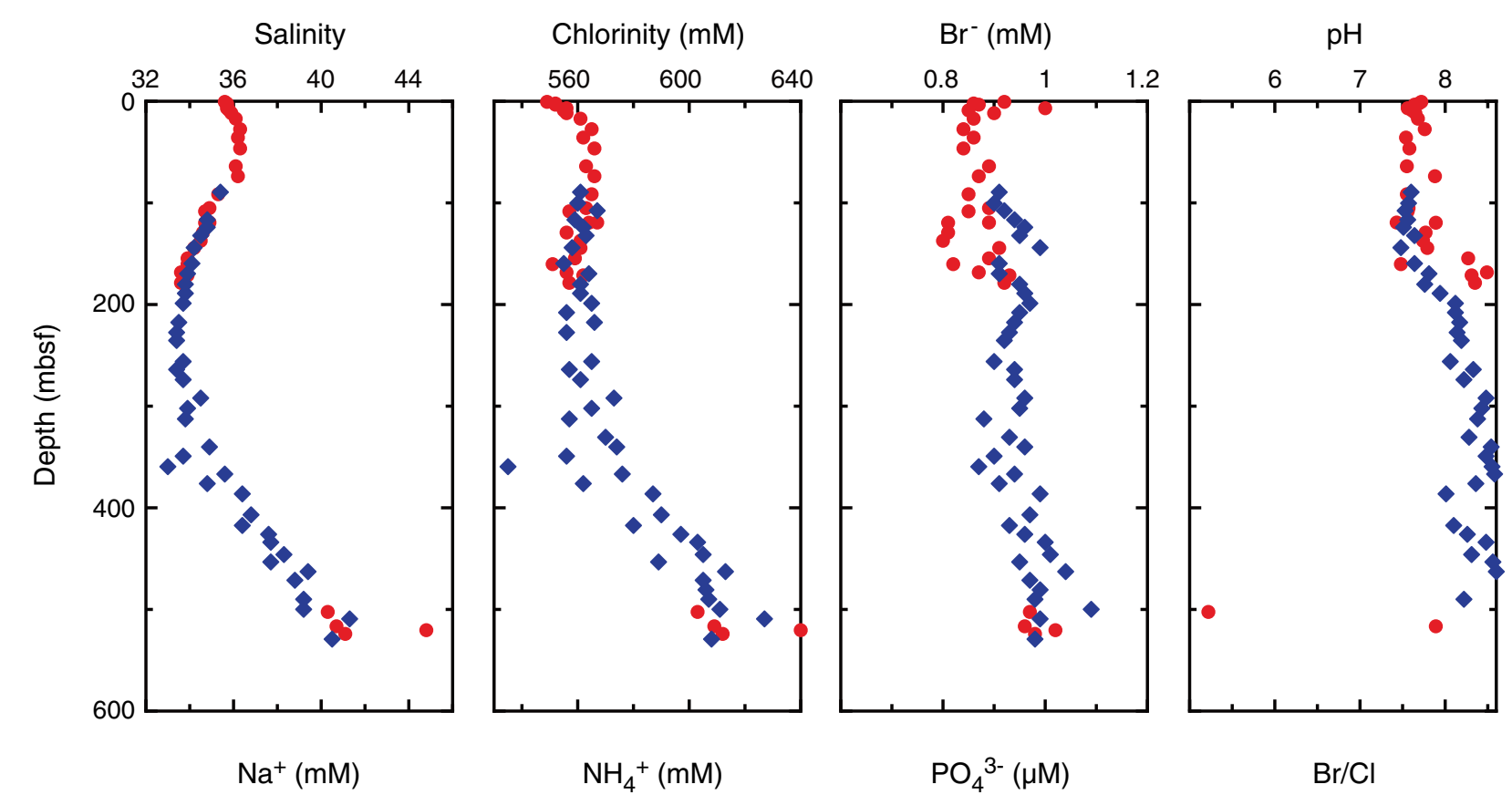

Alkalinity (mM)

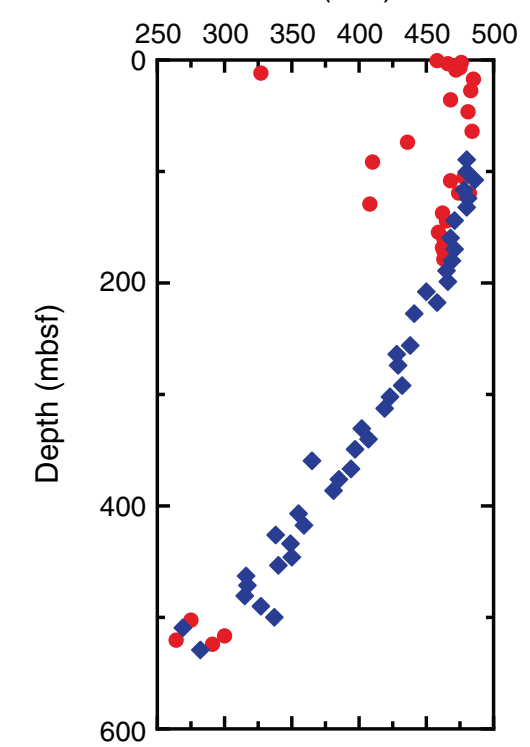

$\mathrm{NH}_{4}^{+}(\mathrm{mM})$

$\mathrm{PO}_{4}{ }^{3-}(\mu \mathrm{M})$

$\mathrm{Br} / \mathrm{Cl}$
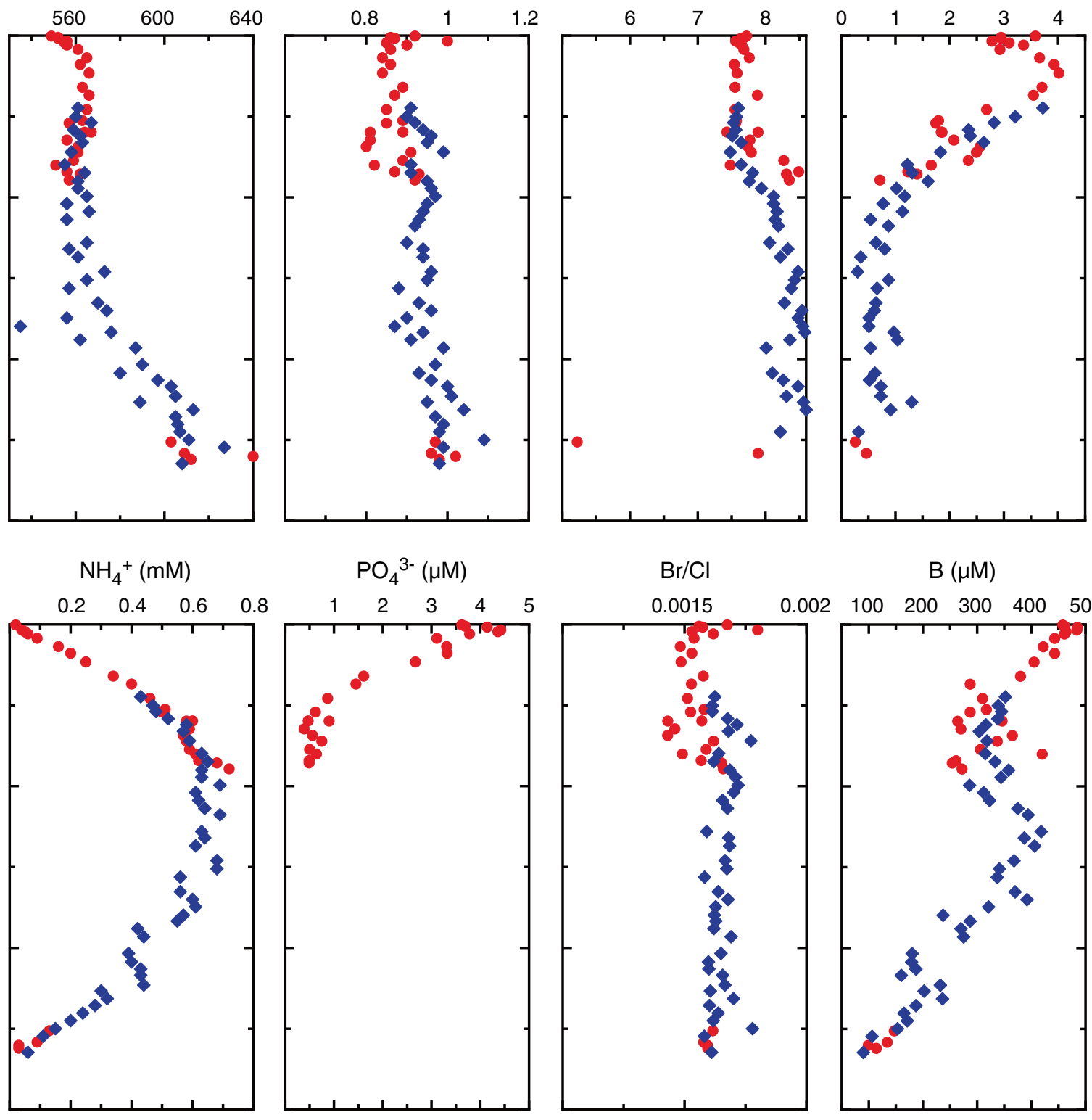

$\mathrm{B}(\mu \mathrm{M})$

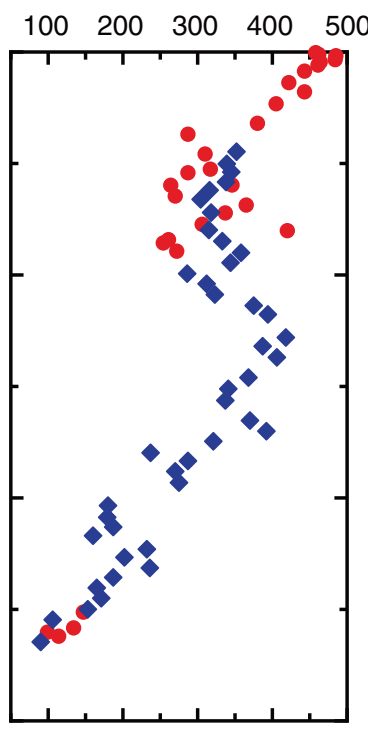


Figure F47. Interstitial water constituents (potassium, magnesium, calcium, $\mathrm{Ca} / \mathrm{Mg}$, silica, iron, lithium, strontium, barium, and manganese). Red $=$ Holes C0012C, C0012D, C0012E, and C0012G; blue = Expedition 322 Hole C0012A (Expedition 322 Scientists, 2010; table T20).
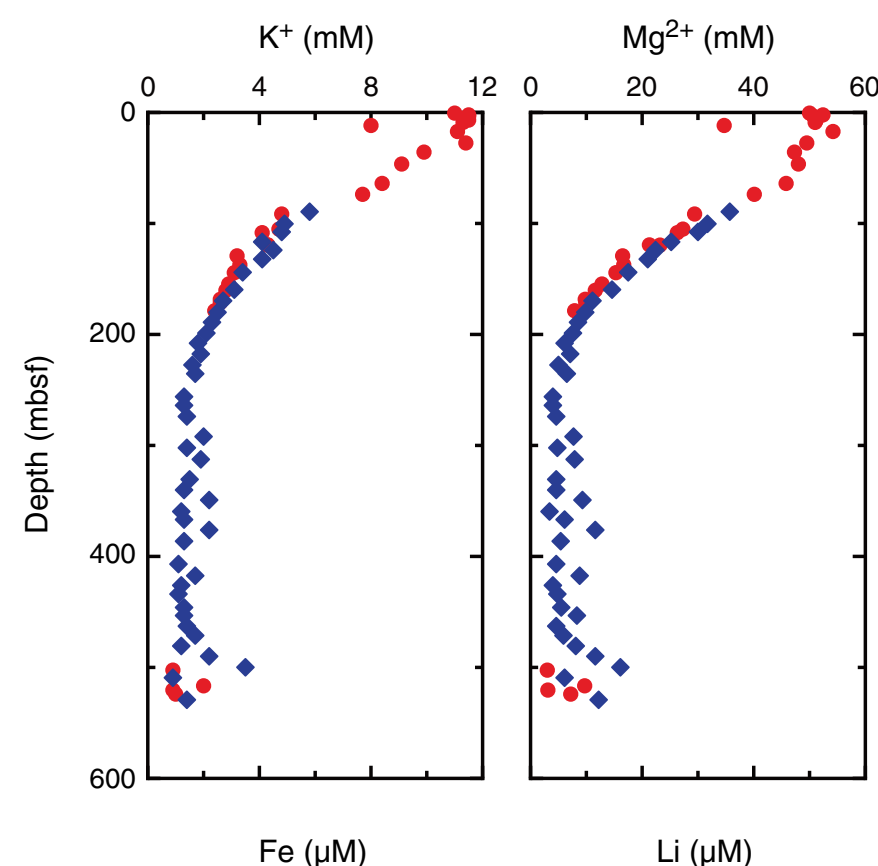

$\mathrm{Ca}^{2+}(\mathrm{mM})$

$\mathrm{Si}(\mu \mathrm{M})$

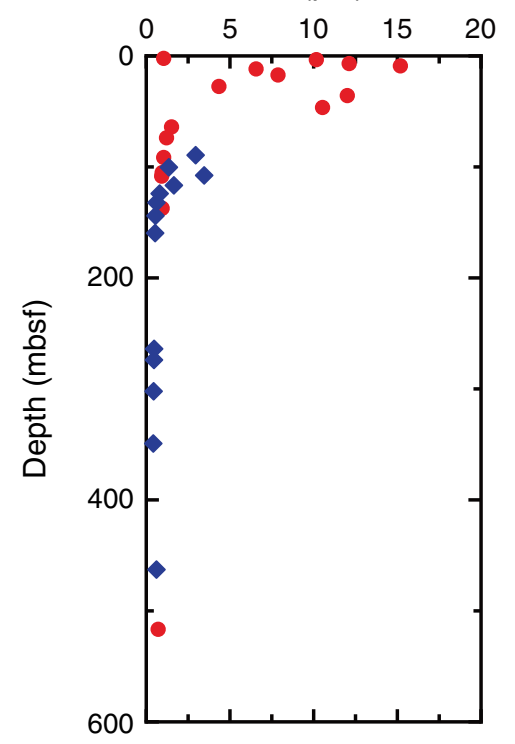

$\mathrm{Li}(\mu \mathrm{M})$
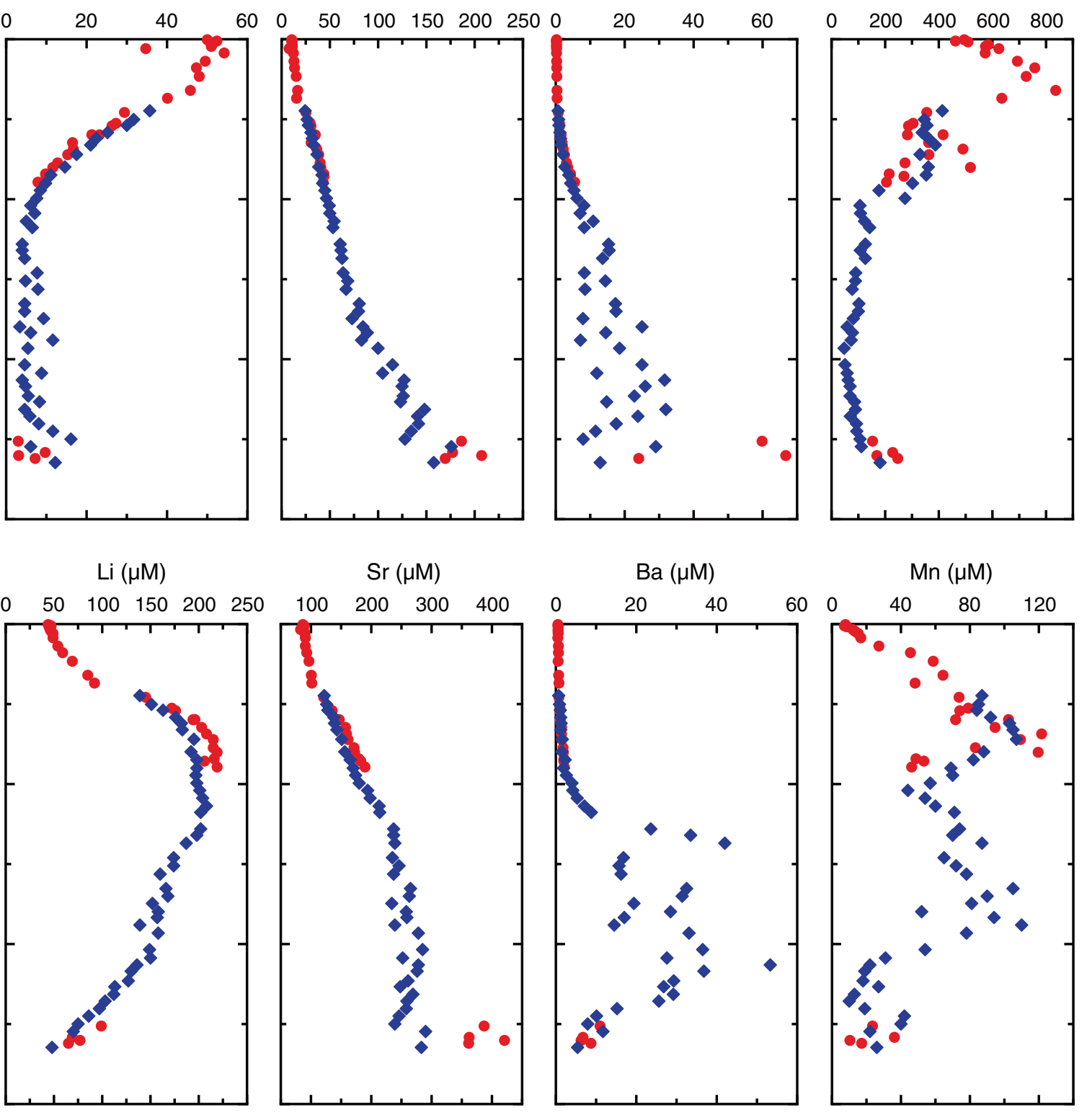
Figure F48. Interstitial water constituents (rubidium, cesium, vanadium, copper, zinc, molybdenum, lead, and uranium). Red $=$ Holes C0012C, C0012D, C0012E, and C0012G; blue = Expedition 322 Hole C0012A (Expedition 322 Scientists, 2010; table T20).
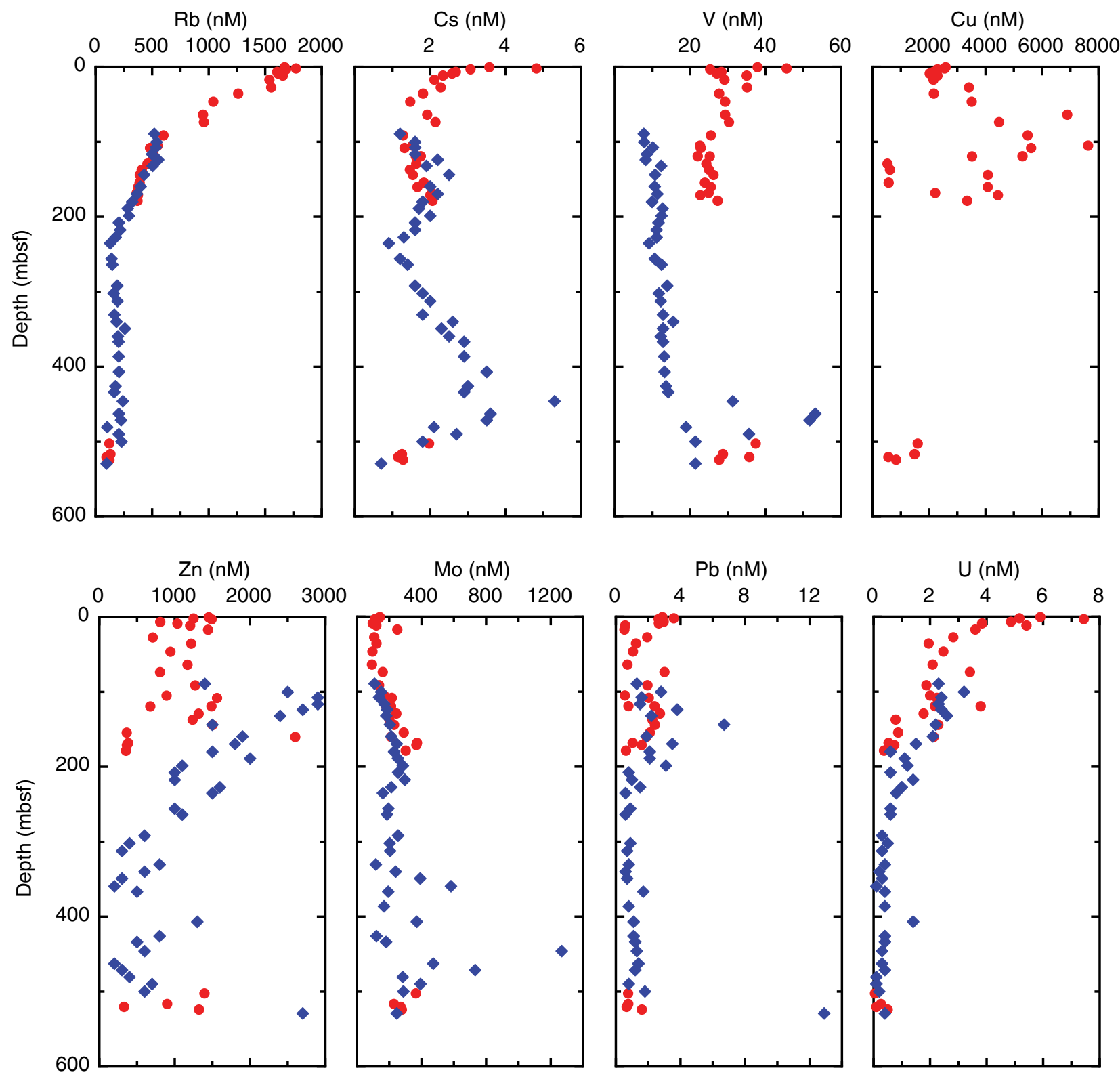
Figure F49. Headspace methane concentration, ethane concentration, and the ratios of methane to ethane (C1/C2), Holes C0012C, C0012D, C0012E, and C0012G. Methane and ethane are set at 0.0 when below detection. C1/C2 is set at 100,000 when ethane concentration is below detection. ppmv = parts per million by volume.

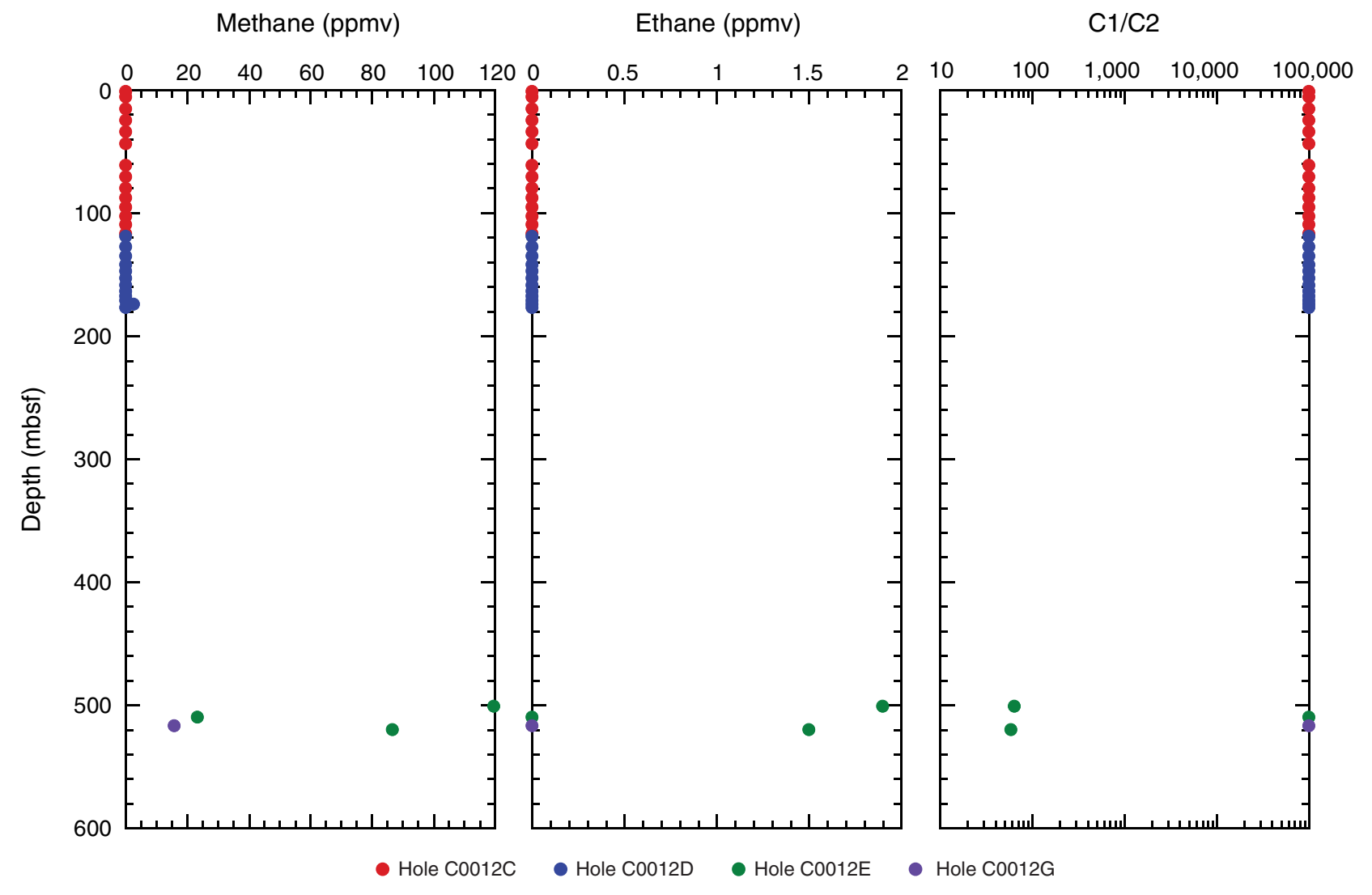


Figure F50. Calcium carbonate $\left(\mathrm{CaCO}_{3}\right)$, total organic carbon (TOC), total nitrogen (TN), atomic ratios of TOC to TN (TOC/TN ${ }_{\mathrm{at}}$ ), and total sulfur (TS) in bulk sediment, Holes C0012C, C0012D, C0012E, and C0012G.

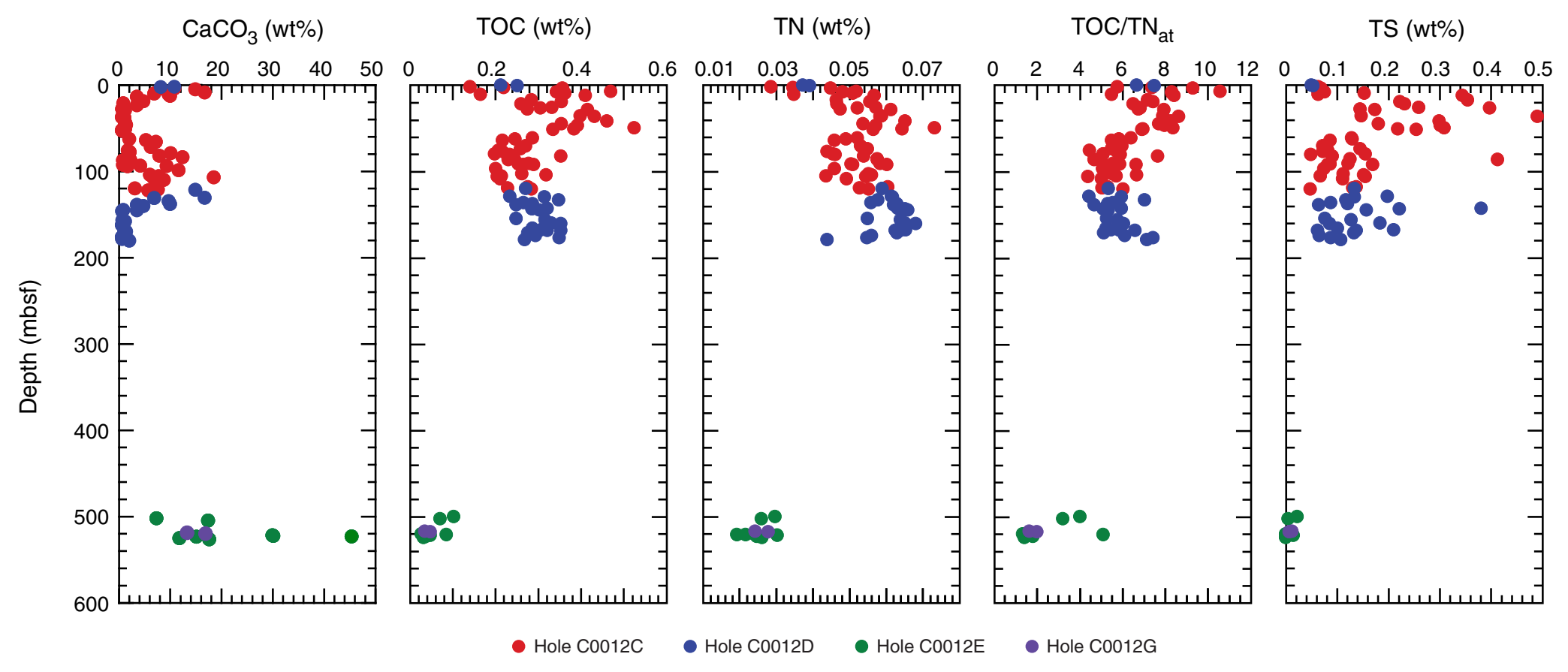


Figure F51. Rock-Eval pyrolysis parameters: S1, S2, $T_{\max }$, hydrogen index (HI), and production index (PI), Holes C0012C and C0012D. HC = hydrocarbon, TOC $=$ total organic carbon.

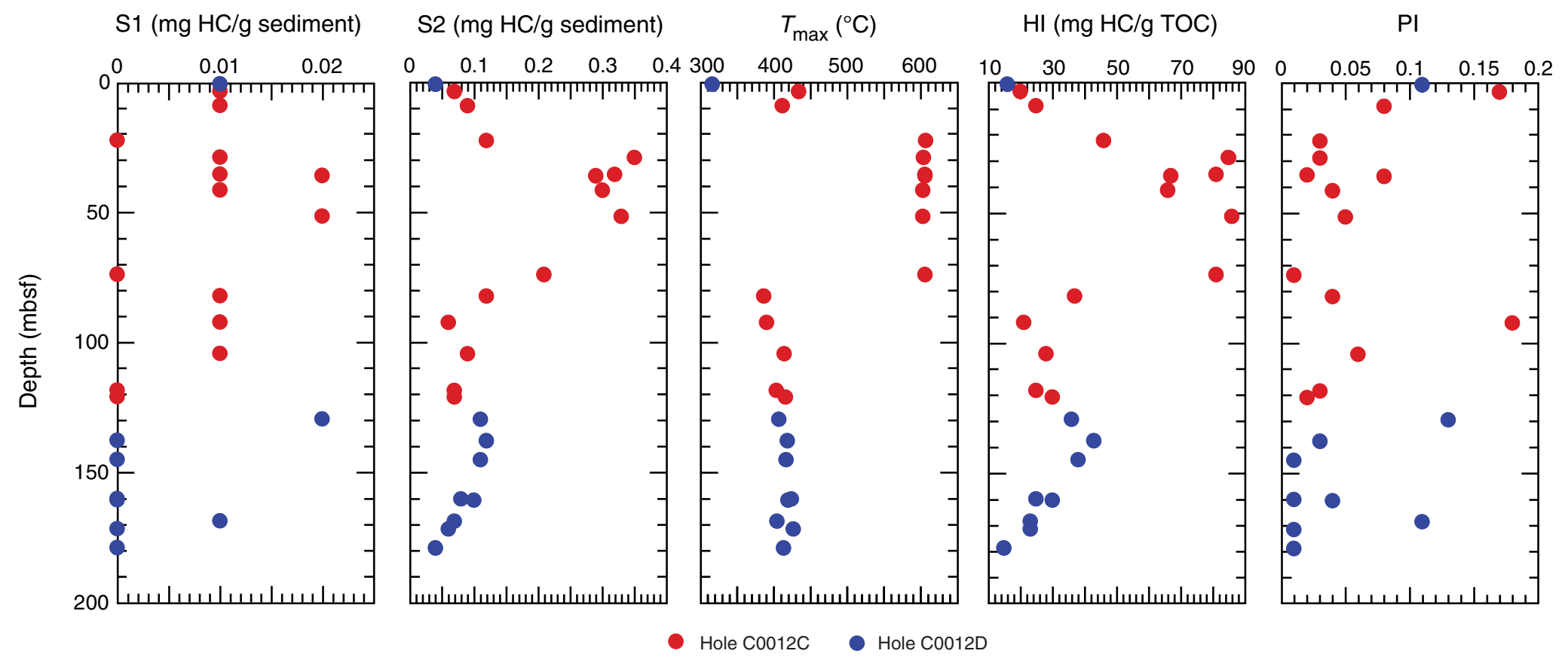


Figure F52. Lithology of Site C0012 basement showing recovery rate, igneous units, lithology, and alteration patterns. In Hole C0012A, basement rocks were cored only from Unit I.

Core recovery

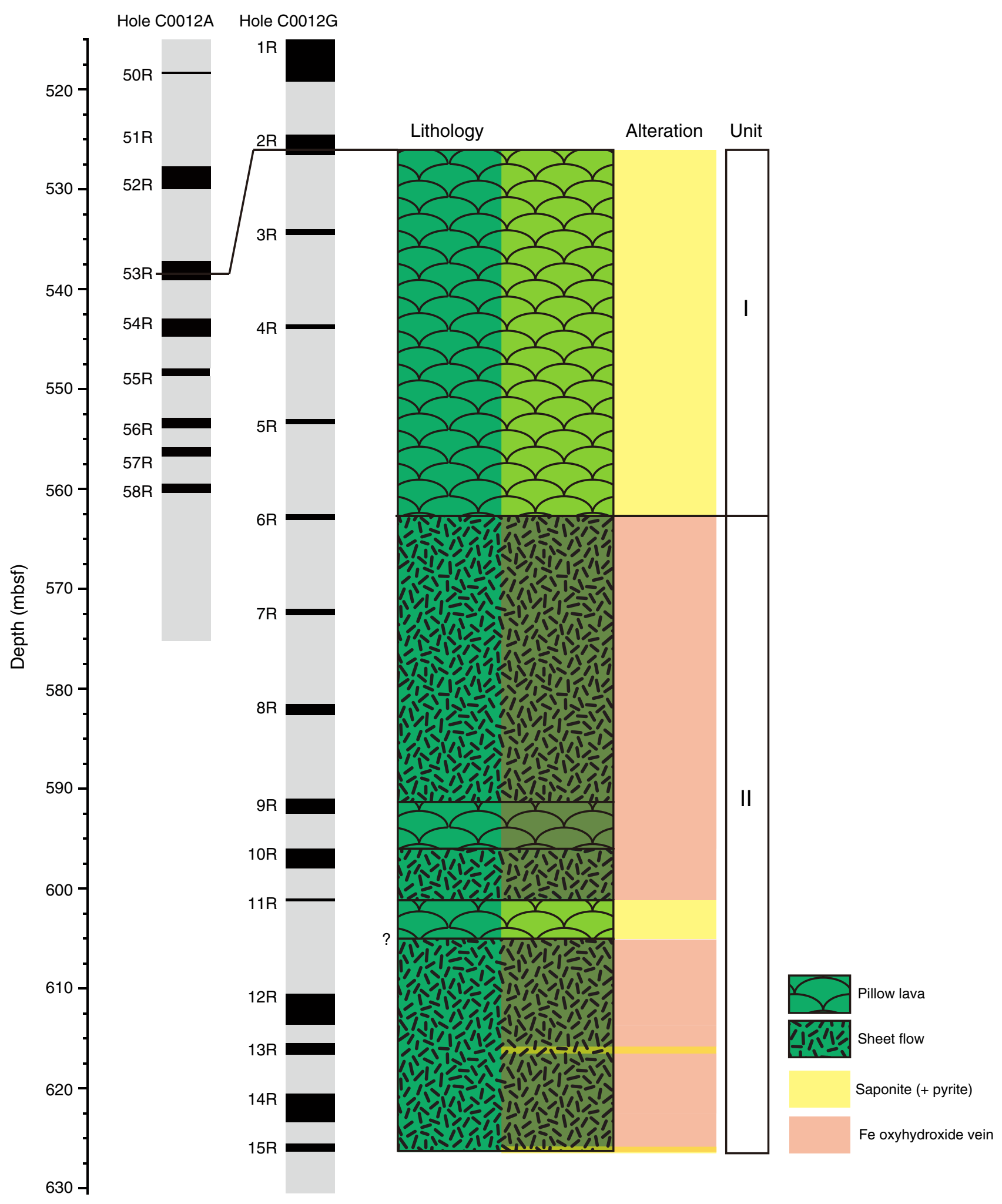


Table T1. Coring summary, Site C0012. (Continued on next page.)

\section{Hole C0012C}

Latitude: $32^{\circ} 44.8947^{\prime} \mathrm{N}$

Longitude: $136^{\circ} 55.0417^{\prime} \mathrm{E}$

Seafloor (DRF, m): 3539.0

Total depth (DRF, m): 3662.5

Total penetration (DSF, m): 123.5

Total length of cored section (m): 124.5

Total core recovered $(\mathrm{m}): 128.62$

Core recovery (\%): 103.3

Total number of cores: 15

\section{Hole C0012D}

Latitude: $32^{\circ} 44.9001^{\prime} \mathrm{N}$

Longitude: $136^{\circ} 55.0418^{\prime} \mathrm{E}$

Seafloor (DRF, m): 3539.0

Total depth (DRF, m): 3739.0

Total penetration (DSF, m): 180

Total length of cored section $(\mathrm{m}): 63.8$

Total core recovered $(\mathrm{m}): 66.38$

Core recovery (\%): 104

Total number of cores: 13

\section{Hole C0012E}

Latitude: $32^{\circ} 44.9001^{\prime} \mathrm{N}$

Longitude: $136^{\circ} 55.0418^{\prime} \mathrm{E}$

Seafloor (DRF, $m): 3539.0$

Total depth (DRF, m): 4067.5

Total penetration (DSF, m): 528.5

Total length of cored section (m): 28.5

Total core recovered $(\mathrm{m}): 13.85$

Core recovery (\%): 48.6

Total number of cores: 3

\section{Hole C0012F}

Latitude: $32^{\circ} 44.8815^{\prime} \mathrm{N}$

Longitude: $136^{\circ} 55.0066^{\prime} \mathrm{E}$

Seafloor (DRF, m): 3539.0

Total depth (DRF, m): 3064.5

Total penetration (DSF, m): 525.5

Total length of cored section $(\mathrm{m}): 5.5$

Total core recovered $(\mathrm{m}): 2.65$

Core recovery (\%): 48.2

Total number of cores: 2

Hole C0012G

Latitude: $32^{\circ} 44.8848^{\prime} \mathrm{N}$

Longitude: $136^{\circ} 55.0153^{\prime} \mathrm{E}$

Seafloor (DRF, m): 3539.0

Total depth (DRF, m): 4169.5

Total penetration (DSF, m): 630.5

Total length of cored section $(\mathrm{m}): 115.5$

Total core recovered $(\mathrm{m}): 25.92$

Core recovery (\%): 22.4

Total number of cores: 15

\begin{tabular}{|c|c|c|c|c|c|}
\hline \multirow[b]{2}{*}{ Core } & \multicolumn{2}{|c|}{ Depth CSF (m) } & \multirow{2}{*}{$\begin{array}{l}\text { Advanced } \\
(\mathrm{m})\end{array}$} & \multirow{2}{*}{$\begin{array}{l}\text { Core } \\
\text { recovered } \\
(\mathrm{m})\end{array}$} & \multirow{2}{*}{$\begin{array}{c}\text { Recovery } \\
(\%)\end{array}$} \\
\hline & Top & Bottom & & & \\
\hline \multicolumn{6}{|c|}{ 333-C0012C- } \\
\hline $1 \mathrm{H}$ & 0.00 & 4.50 & 4.50 & 4.74 & 105.3 \\
\hline $2 \mathrm{H}$ & 4.50 & 14.00 & 9.50 & 9.92 & 104.4 \\
\hline $3 \mathrm{H}$ & 14.00 & 23.50 & 9.50 & 10.02 & 105.5 \\
\hline $4 \mathrm{H}$ & 23.50 & 33.00 & 9.50 & 9.98 & 105.1 \\
\hline $5 \mathrm{H}$ & 33.00 & 42.50 & 9.50 & 9.65 & 101.6 \\
\hline $6 \mathrm{H}$ & 42.50 & 52.00 & 9.50 & 10.14 & 106.7 \\
\hline $7 \mathrm{H}$ & 52.00 & 61.00 & 9.00 & 9.67 & 107.4 \\
\hline $8 \mathrm{H}$ & 60.00 & 69.50 & 9.50 & 9.51 & 100.1 \\
\hline $9 \mathrm{H}$ & 69.50 & 79.00 & 9.50 & 9.03 & 95.1 \\
\hline $10 \mathrm{H}$ & 79.00 & 86.50 & 7.50 & 7.69 & 102.5 \\
\hline $11 \mathrm{H}$ & 86.50 & 94.00 & 7.50 & 7.46 & 99.5 \\
\hline $12 \mathrm{H}$ & 94.00 & 102.00 & 8.00 & 8.17 & 102.1 \\
\hline $13 \mathrm{H}$ & 102.00 & 108.00 & 6.00 & 6.32 & 105.3 \\
\hline $14 \mathrm{H}$ & 108.00 & 116.00 & 8.00 & 8.58 & 107.3 \\
\hline
\end{tabular}


Table T1 (continued).

\begin{tabular}{|c|c|c|c|c|c|}
\hline \multirow[b]{2}{*}{ Core } & \multicolumn{2}{|c|}{ Depth CSF (m) } & \multirow{2}{*}{$\begin{array}{l}\text { Advanced } \\
\text { (m) }\end{array}$} & \multirow{2}{*}{$\begin{array}{l}\text { Core } \\
\text { recovered } \\
\text { (m) }\end{array}$} & \multirow{2}{*}{$\begin{array}{c}\text { Recovery } \\
(\%)\end{array}$} \\
\hline & Top & Bottom & & & \\
\hline $15 \mathrm{H}$ & 116.00 & 123.50 & 7.50 & 7.74 & 103.2 \\
\hline \multicolumn{6}{|l|}{ 333-C0012D- } \\
\hline $1 \mathrm{H}$ & 0.00 & 1.80 & 1.80 & 1.81 & 100.6 \\
\hline Wash down & 1.80 & 118.00 & 116.20 & & \\
\hline $2 \mathrm{H}$ & 118.00 & 126.50 & 8.50 & 8.73 & 102.7 \\
\hline $3 \mathrm{H}$ & 126.50 & 134.00 & 7.50 & 7.65 & 102.0 \\
\hline $4 \mathrm{H}$ & 134.00 & 141.00 & 7.00 & 6.98 & 99.7 \\
\hline Misfire & 141.00 & 141.00 & 0.00 & & \\
\hline $5 \mathrm{H}$ & 141.00 & 146.50 & 5.50 & 5.57 & 101.3 \\
\hline $6 \mathrm{H}$ & 146.50 & 152.00 & 5.50 & 5.92 & 107.6 \\
\hline $7 \mathrm{H}$ & 152.00 & 157.50 & 5.50 & 5.52 & 100.4 \\
\hline $8 \mathrm{H}$ & 157.50 & 162.50 & 5.00 & 4.98 & 99.6 \\
\hline $9 \mathrm{H}$ & 162.50 & 167.00 & 4.50 & 4.79 & 106.4 \\
\hline $10 \mathrm{H}$ & 167.00 & 170.50 & 3.50 & 3.56 & 101.7 \\
\hline $11 \mathrm{H}$ & 170.50 & 173.50 & 3.00 & 3.68 & 122.7 \\
\hline $12 \mathrm{H}$ & 173.50 & 176.00 & 2.50 & 2.51 & 100.4 \\
\hline $13 \mathrm{H}$ & 176.00 & 180.00 & 4.00 & 4.68 & 117.0 \\
\hline \multicolumn{6}{|l|}{ 333-C0012E- } \\
\hline Wash down & 0.00 & 500.00 & & & \\
\hline $1 \mathrm{X}$ & 500 & 509.5 & 9.5 & 4.42 & 46.5 \\
\hline $2 \mathrm{x}$ & 509.5 & 519 & 9.5 & 0.78 & 8.2 \\
\hline $3 x$ & 519 & 528.5 & 9.5 & 8.35 & 87.9 \\
\hline \multicolumn{6}{|l|}{ 333-C0012F- } \\
\hline Wash down & 0.00 & 520.00 & 520.00 & 0.00 & 0.0 \\
\hline $1 \mathrm{R}$ & 520 & 522.5 & 2.5 & 1.03 & 41.2 \\
\hline $2 \mathrm{R}$ & 522.5 & 525.5 & 3 & 1.41 & 47.0 \\
\hline \multicolumn{6}{|l|}{ 333-C0012G- } \\
\hline Wash down & 0.00 & 515.00 & 515.00 & & \\
\hline $1 \mathrm{R}$ & 515.00 & 524.50 & 9.50 & 4.35 & 45.8 \\
\hline $2 \mathrm{R}$ & 524.50 & 534.00 & 9.50 & 2.06 & 21.7 \\
\hline $3 R$ & 534.00 & 543.50 & 9.50 & 0.91 & 9.6 \\
\hline $4 \mathrm{R}$ & 543.50 & 553.00 & 9.50 & 1.02 & 10.7 \\
\hline $5 \mathrm{R}$ & 553.00 & 562.50 & 9.50 & 0.6 & 6.3 \\
\hline $6 \mathrm{R}$ & 562.50 & 572.00 & 9.50 & 1.14 & 12.0 \\
\hline $7 \mathrm{R}$ & 572.00 & 581.50 & 9.50 & 0.91 & 9.6 \\
\hline $8 \mathrm{R}$ & 581.50 & 591.00 & 9.50 & 1.42 & 14.9 \\
\hline $9 \mathrm{R}$ & 591.00 & 596.00 & 5.00 & 1.68 & 33.6 \\
\hline $10 \mathrm{R}$ & 596.00 & 601.00 & 5.00 & 2.06 & 41.2 \\
\hline $11 \mathrm{R}$ & 601.00 & 610.50 & 9.50 & 0.39 & 4.1 \\
\hline $12 \mathrm{R}$ & 610.50 & 615.50 & 5.00 & 3.36 & 67.2 \\
\hline $13 \mathrm{R}$ & 615.50 & 620.50 & 5.00 & 1.42 & 28.4 \\
\hline $14 \mathrm{R}$ & 620.50 & 625.50 & 5.00 & 3.66 & 73.2 \\
\hline $15 \mathrm{R}$ & 625.50 & 630.50 & 5.00 & 0.94 & 18.8 \\
\hline
\end{tabular}

$\mathrm{DRF}=$ drilling depth below rig floor, $\mathrm{DSF}=$ drilling depth below seafloor, $\mathrm{CSF}=$ core depth below seafloor. $\mathrm{H}=\mathrm{hydraulic}$ piston coring system, $\mathrm{X}$ $=$ extended shoe coring system, $\mathrm{R}=$ rotary core barrel coring system. 
Table T2. Results of bulk powder X-ray diffraction analysis, Holes C0012C, C0012D and C0012E. (Continued on next page.)

\begin{tabular}{|c|c|c|c|c|c|c|c|c|c|c|c|c|c|c|c|c|c|c|c|}
\hline \multirow[b]{3}{*}{$\begin{array}{l}\text { Lith. } \\
\text { unit }\end{array}$} & \multirow[b]{3}{*}{$\begin{array}{l}\text { Core, section, } \\
\text { interval }(\mathrm{cm})\end{array}$} & \multirow[b]{3}{*}{$\begin{array}{l}\text { Depth } \\
\text { (mbsf) }\end{array}$} & \multicolumn{8}{|c|}{ Measured values of $X$-ray diffraction peaks } & \multicolumn{9}{|c|}{ Abundance calculated from SVD normalization factors } \\
\hline & & & \multicolumn{4}{|c|}{ Peak intensity (counts/step) } & \multicolumn{4}{|c|}{ Integrated peak area (total counts) } & \multicolumn{5}{|c|}{ Absolute (wt\%) } & \multicolumn{4}{|c|}{ Relative (wt\%) } \\
\hline & & & 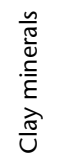 & \begin{tabular}{l}
$\frac{N}{0}$ \\
ơ \\
\multirow{2}{0}{}
\end{tabular} & 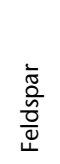 & 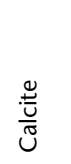 & $\begin{array}{l}\frac{n}{\bar{\pi}} \\
\frac{\vec{\pi}}{\bar{\varepsilon}} \\
\frac{\pi}{U} \\
\frac{\pi}{U}\end{array}$ & 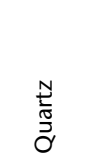 & $\begin{array}{l}\frac{\bar{o}}{0} \\
\frac{\overline{0}}{\overline{0}} \\
\frac{0}{\omega}\end{array}$ & $\frac{\stackrel{ \pm}{U}}{\tilde{U}}$ & $\begin{array}{l}\frac{n}{\tilde{J}} \\
\frac{\tilde{U}}{\tilde{\varepsilon}} \\
\frac{\pi}{U} \\
\end{array}$ & $\begin{array}{l}\frac{1}{0} \\
\frac{0}{0} \\
\frac{0}{2}\end{array}$ & $\begin{array}{l}\frac{\bar{o}}{0} \\
\frac{0}{\overline{0}} \\
\frac{0}{\omega}\end{array}$ & $\frac{\stackrel{ \pm}{U}}{\tilde{U}}$ & $\begin{array}{l}\overline{\widetilde{0}} \\
\stackrel{\circ}{\circ}\end{array}$ & 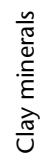 & 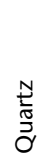 & $\frac{\frac{1}{0}}{\frac{0}{0}}$ & 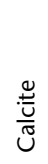 \\
\hline \multirow{44}{*}{1} & \multicolumn{19}{|l|}{ 333-C0012C- } \\
\hline & $\begin{array}{l}1 \mathrm{H}-2,113 \\
1 \mathrm{H}-2,123\end{array}$ & $\begin{array}{l}2.39 \\
2.48\end{array}$ & $\begin{array}{l}30 \\
32\end{array}$ & $\begin{array}{l}614 \\
621\end{array}$ & $\begin{array}{l}153 \\
135\end{array}$ & $\begin{array}{l}285 \\
213\end{array}$ & $\begin{array}{l}2,114 \\
2,374\end{array}$ & $\begin{array}{l}21,332 \\
21,966\end{array}$ & $\begin{array}{l}12,676 \\
13,953\end{array}$ & $\begin{array}{r}10,890 \\
8,749\end{array}$ & $\begin{array}{l}29.6 \\
33.0\end{array}$ & $\begin{array}{l}11.7 \\
12.0\end{array}$ & $\begin{array}{l}15.7 \\
17.4\end{array}$ & $\begin{array}{r}11.6 \\
8.5\end{array}$ & $\begin{array}{l}68.6 \\
70.8\end{array}$ & $\begin{array}{l}43 \\
47\end{array}$ & 17 & $\begin{array}{l}23 \\
25\end{array}$ & $\begin{array}{l}17 \\
12\end{array}$ \\
\hline & $1 \mathrm{H}-3,95$ & 3.53 & 43 & 621 & 109 & 368 & 3,596 & 22,643 & 8,269 & 14,382 & 41.1 & 12.4 & 9.2 & 15.1 & 77.9 & 53 & 16 & 12 & 19 \\
\hline & $2 \mathrm{H}-2,128.5$ & 7.05 & 34 & 627 & 117 & 425 & 2,630 & 23,160 & 9,279 & 16,246 & 32.4 & 12.9 & 10.8 & 18.2 & 74.3 & 44 & 17 & 15 & 25 \\
\hline & $2 \mathrm{H}-3,124.5$ & 8.34 & 44 & 838 & 137 & 180 & 3,334 & 30,002 & 11,052 & 6,930 & 39.9 & 16.7 & 12.7 & 5.3 & 74.6 & 54 & 22 & 17 & 7 \\
\hline & $2 \mathrm{H}-4,70$ & 9.15 & 39 & 724 & 140 & 221 & 3,387 & 25,727 & 11,606 & 9,468 & 41.1 & 14.1 & 13.7 & 8.7 & 77.6 & 53 & 18 & 18 & 11 \\
\hline & $2 \mathrm{H}-5,121.5$ & 10.97 & 39 & 626 & 111 & 247 & 3,777 & 22,490 & 9,883 & 9,199 & 43.9 & 12.2 & 11.4 & 8.2 & 75.7 & 58 & 16 & 15 & 11 \\
\hline & $2 \mathrm{H}-6,78$ & 11.91 & 39 & 742 & 135 & 95 & 3,677 & 27,609 & 11,956 & 4,063 & 44.0 & 15.1 & 14.0 & 1.3 & 74.4 & 59 & 20 & 19 & 2 \\
\hline & $3 \mathrm{H}-3,75$ & 17.35 & 46 & 644 & 117 & 114 & 3,443 & 23,475 & 9,349 & 4,380 & 40.0 & 12.9 & 10.7 & 2.1 & 65.6 & 61 & 20 & 16 & 3 \\
\hline & $3 \mathrm{H}-5,8$ & 19.40 & 49 & 720 & 113 & 22 & 4,818 & 27,190 & 9,051 & 855 & 53.0 & 14.8 & 9.7 & 0.1 & 77.7 & 68 & 19 & 13 & $\operatorname{Tr}$ \\
\hline & $3 \mathrm{H}-6,119.5$ & 21.78 & 36 & 601 & 107 & 81 & 3,281 & 22,775 & 9,244 & 3,742 & 38.3 & 12.5 & 10.6 & 1.4 & 62.8 & 61 & 20 & 17 & 2 \\
\hline & $4 \mathrm{H}-2,125.5$ & 26.00 & 42 & 810 & 132 & 17 & 4,758 & 29,058 & 9,790 & 951 & 52.9 & 15.9 & 10.7 & 0.1 & 79.6 & 66 & 20 & 13 & $\operatorname{Tr}$ \\
\hline & $4 \mathrm{H}-3,28$ & 26.41 & 49 & 710 & 109 & 22 & 4,842 & 26,114 & 9,009 & 1,019 & 53.3 & 14.2 & 9.7 & 0.1 & 77.3 & 69 & 18 & 13 & $\operatorname{Tr}$ \\
\hline & $4 \mathrm{H}-4,20$ & 27.67 & 52 & 790 & 147 & 28 & 4,412 & 28,502 & 11,932 & 1,620 & 51.1 & 15.5 & 13.7 & 0.1 & 80.4 & 63 & 19 & 17 & $\operatorname{Tr}$ \\
\hline & $4 \mathrm{H}-5,100$ & 28.62 & 38 & 740 & 124 & 25 & 3,988 & 27,165 & 10,967 & 990 & 46.2 & 14.9 & 12.6 & 0.1 & 73.8 & 63 & 20 & 17 & $\operatorname{Tr}$ \\
\hline & $5 \mathrm{H}-2,121$ & 35.53 & 53 & 773 & 128 & 12 & 4,976 & 28,708 & 11,392 & 938 & 56.2 & 15.6 & 12.8 & 0.1 & 84.7 & 66 & 18 & 15 & $\operatorname{Tr}$ \\
\hline & $5 \mathrm{H}-3,21$ & 35.93 & 43 & 808 & 140 & 26 & 4,319 & 29,346 & 11,375 & 1,319 & 49.7 & 16.1 & 12.9 & 0.1 & 78.8 & 63 & 20 & 16 & $\operatorname{Tr}$ \\
\hline & $5 \mathrm{H}-7,125$ & 41.31 & 48 & 810 & 118 & 35 & 4,270 & 29,565 & 9,994 & 1,806 & 48.2 & 16.3 & 11.1 & 0.1 & 75.6 & 64 & 22 & 15 & $\operatorname{Tr}$ \\
\hline & $6 \mathrm{H}-2,79$ & 44.55 & 47 & 746 & 121 & 32 & 4,663 & 27,129 & 10,788 & 2,534 & 52.8 & 14.8 & 12.1 & 0.1 & 79.8 & 66 & 18 & 15 & $\operatorname{Tr}$ \\
\hline & $6 \mathrm{H}-4,21.5$ & 46.65 & 52 & 779 & 108 & 18 & 4,697 & 27,553 & 9,133 & 1,082 & 51.9 & 15.1 & 9.9 & 0.1 & 76.9 & 67 & 20 & 13 & $\operatorname{Tr}$ \\
\hline & $6 \mathrm{H}-6,126.5$ & 49.17 & 53 & 759 & 117 & 29 & 5,098 & 28,505 & 9,576 & 2,171 & 56.2 & 15.5 & 10.3 & 0.1 & 82.1 & 68 & 19 & 13 & $\operatorname{Tr}$ \\
\hline & $6 \mathrm{H}-8,29$ & 50.89 & 54 & 823 & 107 & 15 & 4,977 & 29,609 & 9,791 & 853 & 55.0 & 16.2 & 10.6 & 0.1 & 81.9 & 67 & 20 & 13 & $\operatorname{Tr}$ \\
\hline & $6 \mathrm{H}-8,90$ & 51.46 & 49 & 786 & 130 & 17 & 4,620 & 28,809 & 11,114 & 1,023 & 52.5 & 15.7 & 12.5 & 0.1 & 80.9 & 65 & 19 & 16 & $\operatorname{Tr}$ \\
\hline & $7 \mathrm{H}-4,54$ & 55.15 & 43 & 705 & 113 & 117 & 4,897 & 26,862 & 8,677 & 5,079 & 53.7 & 14.7 & 9.2 & 1.9 & 79.4 & 68 & 18 & 12 & 2 \\
\hline & $8 \mathrm{H}-1,125$ & 61.16 & 49 & 688 & 103 & 42 & 4,991 & 26,183 & 9,492 & 2,402 & 55.2 & 14.2 & 10.3 & 0.1 & 79.8 & 69 & 18 & 13 & $\operatorname{Tr}$ \\
\hline & $8 \mathrm{H}-2,121.5$ & 62.44 & 52 & 703 & 101 & 116 & 4,993 & 25,435 & 8,627 & 5,401 & 54.7 & 13.8 & 9.2 & 2.3 & 79.9 & 68 & 17 & 11 & 3 \\
\hline & $8 \mathrm{H}-4,21.0$ & 64.14 & 55 & 690 & 108 & 107 & 6,322 & 25,813 & 9,255 & 4,451 & 68.3 & 13.8 & 9.6 & 0.0 & 91.7 & 74 & 15 & 10 & $\operatorname{Tr}$ \\
\hline & $9 \mathrm{H}-1,80$ & 70.29 & 66 & 656 & 96 & 175 & 5,684 & 25,213 & 8,660 & 6,299 & 61.6 & 13.6 & 9.0 & 2.9 & 87.1 & 71 & 16 & 10 & 3 \\
\hline & $9 \mathrm{H}-4,20.5$ & 73.96 & 61 & 806 & 127 & 41 & 5,242 & 29,132 & 10,744 & 2,418 & 58.4 & 15.8 & 11.8 & 0.1 & 86.2 & 68 & 18 & 14 & $\operatorname{Tr}$ \\
\hline & $9 H-6,66$ & 76.05 & 55 & 835 & 128 & 42 & 5,140 & 30,257 & 9,434 & 2,352 & 56.4 & 16.6 & 10.0 & 0.1 & 83.1 & 68 & 20 & 12 & $\operatorname{Tr}$ \\
\hline & $9 \mathrm{H}-7,50$ & 77.32 & 49 & 661 & 96 & 240 & 4,867 & 24,419 & 8,985 & 9,816 & 54.0 & 13.2 & 9.7 & 8.2 & 85.1 & 63 & 16 & 11 & 10 \\
\hline & $10 \mathrm{H}-1,125$ & 80.07 & 62 & 647 & 140 & 37 & 6,027 & 23,430 & 10,592 & 2,109 & 66.3 & 12.4 & 11.7 & 0.1 & 90.5 & 73 & 14 & 13 & $\operatorname{Tr}$ \\
\hline & $10 \mathrm{H}-2,20$ & 80.38 & 54 & 645 & 104 & 162 & 4,714 & 26,136 & 9,776 & 6,854 & 52.8 & 14.2 & 10.8 & 4.3 & 82.1 & 64 & 17 & 13 & 5 \\
\hline & $10 \mathrm{H}-5,42$ & 82.18 & 43 & 635 & 101 & 277 & 4,171 & 22,997 & 8,565 & 11,490 & 46.9 & 12.5 & 9.4 & 10.9 & 79.7 & 59 & 16 & 12 & 14 \\
\hline & $10 \mathrm{H}-9,63$ & 85.61 & 63 & 707 & 119 & 23 & 6,582 & 26,436 & 9,647 & 1,533 & 71.0 & 14.1 & 10.1 & 0.1 & 95.2 & 75 & 15 & 11 & $\operatorname{Tr}$ \\
\hline & $10 \mathrm{H}-9,107$ & 85.98 & 64 & 669 & 101 & 41 & 5,864 & 25,226 & 9,233 & 2,171 & 63.6 & 13.5 & 9.8 & 0.1 & 87.0 & 73 & 16 & 11 & $\operatorname{Tr}$ \\
\hline & $11 \mathrm{H}-4,105$ & 90.76 & 64 & 736 & 115 & 18 & 6,192 & 27,622 & 10,330 & 1,162 & 67.5 & 14.8 & 11.1 & 0.1 & 93.5 & 72 & 16 & 12 & $\operatorname{Tr}$ \\
\hline & $11 \mathrm{H}-6,21$ & 91.70 & 50 & 673 & 90 & 229 & 4,787 & 25,102 & 7,784 & 7,858 & 52.2 & 13.7 & 8.1 & 5.7 & 79.6 & 66 & 17 & 10 & 7 \\
\hline & $11 \mathrm{H}-7,55$ & 92.23 & 51 & 756 & 102 & 236 & 4,452 & 27,708 & 8,877 & 9,784 & 49.6 & 15.2 & 9.5 & 8.3 & 82.7 & 60 & 18 & 12 & 10 \\
\hline & $11 \mathrm{H}-8,20$ & 92.57 & 69 & 777 & 133 & 35 & 5,055 & 29,147 & 11,036 & 1,995 & 56.8 & 15.9 & 12.3 & 0.1 & 85.0 & 67 & 19 & 14 & $\operatorname{Tr}$ \\
\hline & $12 \mathrm{H}-3,36$ & 96.89 & 52 & 702 & 98 & 269 & 5,277 & 25,505 & 8,495 & 11,468 & 57.7 & 13.8 & 8.9 & 10.0 & 90.4 & 64 & 15 & 10 & 11 \\
\hline & $13 \mathrm{H}-1,60$ & 102.47 & 49 & 793 & 125 & 156 & 5,194 & 28,873 & 10,751 & 6,962 & 58.2 & 15.7 & 11.8 & 4.0 & 89.7 & 65 & 18 & 13 & 4 \\
\hline & $13 \mathrm{H}-2,125$ & 104.08 & 55 & 663 & 142 & 183 & 5,442 & 25,241 & 10,710 & 8,288 & 60.8 & 13.5 & 11.9 & 5.6 & 91.9 & 66 & 15 & 13 & 6 \\
\hline & $13 \mathrm{H}-4,27.5$ & 105.32 & 48 & 608 & 93 & 361 & 4,510 & 22,216 & 7,560 & 15,913 & 49.8 & 12.1 & 7.9 & 16.5 & 86.3 & 58 & 14 & 9 & 19 \\
\hline
\end{tabular}




\begin{tabular}{|c|c|c|c|c|c|c|c|c|c|c|c|c|c|c|c|c|c|c|c|}
\hline \multirow[b]{3}{*}{$\begin{array}{l}\text { Lith. } \\
\text { unit }\end{array}$} & \multirow[b]{3}{*}{$\begin{array}{l}\text { Core, section, } \\
\text { interval }(\mathrm{cm})\end{array}$} & \multirow[b]{3}{*}{$\begin{array}{l}\text { Depth } \\
\text { (mbsf) }\end{array}$} & \multicolumn{8}{|c|}{ Measured values of X-ray diffraction peaks } & \multicolumn{9}{|c|}{ Abundance calculated from SVD normalization factors } \\
\hline & & & \multicolumn{4}{|c|}{ Peak intensity (counts/step) } & \multicolumn{4}{|c|}{ Integrated peak area (total counts) } & \multicolumn{5}{|c|}{ Absolute (wt\%) } & \multicolumn{4}{|c|}{ Relative (wt\%) } \\
\hline & & & 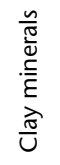 & $\begin{array}{l}\frac{1}{0} \\
\frac{0}{2} \\
0\end{array}$ & $\frac{\sqrt{0}}{\frac{0}{0}}$ & $\frac{\stackrel{\mathscr{V}}{\frac{V}{\sigma}}}{\mathrm{J}}$ & 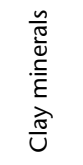 & $\begin{array}{l}\frac{v}{2} \\
\text { ơ } \\
\text { Ơ }\end{array}$ & 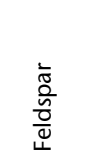 & $\frac{\stackrel{\mathscr{U}}{U}}{\frac{U}{U}}$ & 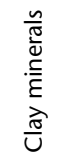 & $\begin{array}{l}\frac{1}{0} \\
\frac{0}{0} \\
\frac{0}{2}\end{array}$ & $\begin{array}{l}\frac{1}{\bar{\sigma}} \\
\frac{\overline{0}}{\frac{0}{0}} \\
\frac{0}{4}\end{array}$ & 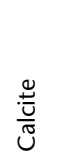 & $\begin{array}{l}\bar{\pi} \\
\stackrel{0}{0}\end{array}$ & $\begin{array}{l}\frac{n}{\bar{\sigma}} \\
\stackrel{\bar{\sigma}}{\bar{\varepsilon}} \\
\frac{\vec{\varepsilon}}{\sigma} \\
\frac{\pi}{U}\end{array}$ & 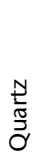 & 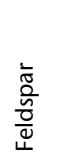 & 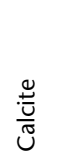 \\
\hline & $13 \mathrm{H}-5,120$ & 106.27 & 52 & 750 & 126 & 154 & 5,214 & 28,748 & 9,873 & 6,727 & 57.7 & 15.7 & 10.6 & 3.7 & 87.7 & 66 & 18 & 12 & 4 \\
\hline & $14 \mathrm{H}-2,26.5$ & 108.55 & 56 & 714 & 96 & 219 & 5,260 & 26,506 & 9,000 & 8,874 & 57.7 & 14.4 & 9.5 & 6.6 & 88.2 & 65 & 16 & 11 & 7 \\
\hline & $15 \mathrm{H}-2,125.5$ & 118.09 & 60 & 805 & 134 & 78 & 5,820 & 29,606 & 11,136 & 3,601 & 64.5 & 16.0 & 12.2 & 0.1 & 92.7 & 70 & 17 & 13 & $\operatorname{Tr}$ \\
\hline & $15 \mathrm{H}-4,29.5$ & 119.55 & 61 & 736 & 110 & 179 & 5,146 & 26,845 & 9,204 & 7,140 & 56.7 & 14.6 & 9.8 & 4.4 & 85.4 & 66 & 17 & 12 & 5 \\
\hline & $15 \mathrm{H}-5,126$ & 120.55 & 72 & 737 & 105 & 155 & 5,826 & 28,194 & 9,346 & 6,030 & 63.4 & 15.3 & 9.8 & 2.4 & 90.8 & 70 & 17 & 11 & 3 \\
\hline & & & & & & & & & & & & & & & Average: & 64 & 18 & 14 & 4 \\
\hline & 333-C0012D- & & & & & & & & & & & & & & & & & & \\
\hline & $1 \mathrm{H}-1,24.5$ & 0.24 & 31 & 639 & 159 & 291 & 2,470 & 23,088 & 12,026 & 12,027 & 32.6 & 12.7 & 14.6 & 12.7 & 72.7 & 45 & 17 & 20 & 18 \\
\hline & $1 \mathrm{H}-2,19$ & 0.78 & 42 & 563 & 128 & 370 & 3,145 & 20,068 & 9,162 & 13,816 & 37.4 & 10.9 & 10.6 & 14.8 & 73.8 & 51 & 15 & 14 & 20 \\
\hline & $2 \mathrm{H}-3,26.5$ & 119.73 & 61 & 774 & 113 & 149 & 6,183 & 27,648 & 10,170 & 6,246 & 67.5 & 14.9 & 10.8 & 2.4 & 95.6 & 71 & 16 & 11 & 2 \\
\hline \multirow[t]{22}{*}{ I } & $3 \mathrm{H}-2,125.5$ & 129.05 & 61 & 841 & 122 & 17 & 6,553 & 30,111 & 9,368 & 847 & 70.3 & 16.3 & 9.5 & 0.1 & 96.2 & 73 & 17 & 10 & $\mathrm{Tr}$ \\
\hline & $3 \mathrm{H}-3,28.5$ & 129.47 & 67 & 726 & 92 & 134 & 6,011 & 27,115 & 9,239 & 5,55 & 65.2 & 14.6 & 9.6 & 1.7 & 91 & 72 & 16 & 11 & 2 \\
\hline & $3 \mathrm{H}-6,100$ & 133.15 & 47 & 765 & 130 & 168 & 5,158 & 28,039 & 9,554 & 7,106 & 57.0 & 15.3 & 10.2 & 4.3 & 86.8 & 66 & 18 & 12 & 5 \\
\hline & $4 \mathrm{H}-2,125.5$ & 136.23 & 52 & 713 & 131 & 93 & 5,192 & 26,769 & 11,884 & 4,311 & 58.9 & 14.4 & 13.5 & 0.5 & 87.4 & 67 & 16 & 15 & 1 \\
\hline & $4 \mathrm{H}-4,29.5$ & 137.54 & 62 & 832 & 110 & 24 & 5,652 & 30,391 & 9,184 & 1,8 & 61.3 & 16.6 & 9.5 & 0.1 & 87 & 70 & 19 & 11 & $\mathrm{Tr}$ \\
\hline & $4 \mathrm{H}-5,120.5$ & 138.56 & 60 & 816 & 122 & 18 & 6,470 & 29,849 & 10,483 & 1,229 & 70.3 & 16.1 & 11.1 & 0.1 & 97.6 & 72 & 16 & 11 & $\mathrm{Tr}$ \\
\hline & $5 \mathrm{H}-2,108$ & 143.24 & 62 & 851 & 137 & 42 & 5,811 & 30,476 & 10,819 & 2,5 & 64.0 & 16.5 & 11.7 & 0.1 & 92.4 & 69 & 18 & 13 & $\mathrm{Tr}$ \\
\hline & $5 \mathrm{H}-3,15$ & 143.68 & 72 & 742 & 15 & 43 & 6,464 & 29,461 & 11,509 & 2,09 & 71.0 & 15.8 & 12.5 & 0.1 & 99 & 71 & 16 & 13 & $\mathrm{Tr}$ \\
\hline & $5 \mathrm{H}-5,30$ & 144.63 & 64 & 886 & 120 & 15 & 6,526 & 31,562 & 9,627 & 995 & 70.1 & 17.1 & 9.8 & 0.1 & 97.2 & 72 & 18 & 10 & $\mathrm{Tr}$ \\
\hline & $6 \mathrm{H}-6,18$ & 150.21 & 61 & 751 & 119 & 64 & 5,993 & 28,147 & 9,445 & 2,848 & 65.0 & 15.2 & 9.9 & 0.1 & 90.1 & 72 & 17 & 11 & $\mathrm{Tr}$ \\
\hline & & & & & & & & & & & & & & & Average: & 67 & 17 & 12 & 4 \\
\hline & $7 \mathrm{H}-3,29$ & 154.83 & 69 & 702 & 11 & 22 & 7,987 & 25,808 & 4,010 & 1,6 & 85.0 & 13.5 & 9.9 & 0.1 & 108.5 & 78 & 12 & 9 & $\mathrm{Tr}$ \\
\hline & $7 \mathrm{H}-5,20$ & 156.35 & 58 & 828 & 118 & 19 & 5,977 & 30,718 & 10,529 & 1,027 & 65.4 & 16.7 & 11.2 & 0.1 & 93.4 & 70 & 18 & 12 & $\mathrm{Tr}$ \\
\hline & $8 \mathrm{H}-3,56.5$ & 160.12 & 67 & 785 & 117 & 27 & 6,413 & 29,739 & 10,204 & 2,0 & 69.6 & 16.0 & 10.7 & 0.1 & 064 & 72 & 17 & 11 & $\mathrm{Tr}$ \\
\hline & $8 \mathrm{H}-4,29.5$ & 160.55 & 60 & 776 & 113 & 40 & 6,033 & 29,476 & 10,115 & 2,272 & 65.8 & 15.9 & 10.7 & 0.1 & 92.5 & 71 & 17 & 12 & $\mathrm{Tr}$ \\
\hline & $9 \mathrm{H}-3,119.5$ & 165.73 & 64 & 873 & 114 & 22 & 6,207 & 31,902 & 12,053 & 1,248 & 68.7 & 17.3 & 13.2 & 0.1 & 99.3 & 69 & 17 & 13 & $\mathrm{Tr}$ \\
\hline & $10 \mathrm{H}-2,8$ & 167.80 & 72 & 764 & 105 & 52 & 6,547 & 29,286 & 9,820 & 2,486 & 70.7 & 15.8 & 10.2 & 0.1 & 96.7 & 73 & 16 & 11 & $\mathrm{Tr}$ \\
\hline & $10 \mathrm{H}-2,88.5$ & 168.23 & 68 & 794 & 12 & 78 & 6,643 & 29,815 & 10,495 & 3,7 & 72.1 & 16.0 & 11.0 & 0.1 & 99 & 73 & 16 & 11 & $\mathrm{Tr}$ \\
\hline & $10 \mathrm{H}-3,31$ & 168.51 & 66 & 835 & 114 & 51 & 5,984 & 30,476 & 9,980 & 2,321 & 65.1 & 16.5 & 10.5 & 0.1 & 92.3 & 71 & 18 & 11 & $\mathrm{Tr}$ \\
\hline & $11 \mathrm{H}-2,30$ & 171.45 & 66 & 824 & 108 & 24 & 6,499 & 30,024 & 10,818 & 1,102 & 70.8 & 16.2 & 11.5 & 0.1 & 98.6 & 72 & 16 & 12 & $\mathrm{Tr}$ \\
\hline & $12 \mathrm{H}-3,27$ & 174.55 & 58 & 756 & 12 & 197 & ברי & 26,586 & 9819 & 97 & 57.9 & 14.4 & 10.7 & 7.7 & 90 & 64 & 16 & 12 & 8 \\
\hline & $13 \mathrm{H}-1,124.5$ & 176.85 & 68 & 737 & 137 & 70 & 5,886 & 29,259 & 12,705 & 3,269 & 66.3 & 15.7 & 14.3 & 0.1 & 96.4 & 69 & 16 & 15 & $\mathrm{Tr}$ \\
\hline \multirow[t]{12}{*}{ ॥ } & $13 \mathrm{H}-4,31$ & 178.87 & 57 & 683 & 193 & 122 & 4,841 & 24,637 & 17,456 & 6,041 & 59.7 & 13.0 & 21.3 & 2.9 & 97.0 & 62 & 13 & 22 & 3 \\
\hline & & & & & & & & & & & & & & & verage: & 70 & 16 & 13 & 1 \\
\hline & 333-C0012E- & & & & & & & & & & & & & & & & & & \\
\hline & $1 \mathrm{X}-1,24$ & 500.24 & 53 & 540 & 148 & 163 & 5,307 & 20,603 & 9,269 & 7 & 58.6 & 10.9 & 10.2 & 5.5 & 85 & 69 & 13 & 12 & 7 \\
\hline & $1 X-3,61$ & 503.07 & 50 & 427 & 5 & 44 & 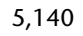 & 16,496 & 5,703 & 17 & 55. & 8. & 5.5 & 19.0 & 88 & 62 & 10 & 6 & 22 \\
\hline & $3 X-1,113.5$ & 520.14 & 41 & 378 & 46 & 561 & 4,373 & 13,589 & 4,272 & 25,850 & 46.8 & 7.2 & 3.8 & 30.0 & 87.8 & 53 & 8 & 4 & 34 \\
\hline & $3 X-2,61$ & 521.02 & 51 & 347 & 42 & 659 & 4,661 & 12,245 & 4,115 & 28,802 & 49.8 & 6.4 & 3.6 & 33.7 & 93.4 & 53 & 7 & 4 & 36 \\
\hline & $3 X-3,36$ & 521.40 & 28 & 313 & 44 & 53 & 2,623 & 10,953 & 3,221 & & 29.2 & 6.0 & 3.0 & 42.9 & 81.1 & 36 & 7 & 4 & 53 \\
\hline & $3 X-4,139.5$ & 521.93 & 58 & 315 & 52 & 240 & 4,695 & 13,076 & 5,401 & 11,882 & 50.3 & 6.7 & 5.4 & 11.5 & 73.9 & 68 & 9 & 7 & 16 \\
\hline & $3 X-4,8.5$ & 523.24 & 58 & 451 & 57 & 241 & 5,422 & 16,799 & 4,868 & 13,068 & 57.0 & 8.8 & 4.3 & 12.4 & 82.4 & 69 & 11 & 5 & 15 \\
\hline & $3 X-6,59.5$ & 524.66 & 50 & 342 & 60 & 345 & 4,768 & 13,510 & 6,626 & 14,675 & 52.0 & 6.9 & 7.0 & 15.0 & 80.9 & 64 & 9 & 9 & 19 \\
\hline & & & & & & & & & & & & & & & Average: & 59 & 9 & 6 & 25 \\
\hline
\end{tabular}


Table T3. Results of XRF analysis, Holes C0012C, C0012D, C0012E, C0012F and C0012G.

\begin{tabular}{|c|c|c|c|c|c|c|c|c|c|c|c|c|c|c|}
\hline \multirow{2}{*}{$\begin{array}{l}\text { Core, section, } \\
\text { interval (cm) }\end{array}$} & \multirow{2}{*}{$\begin{array}{l}\text { Depth } \\
\text { (mbsf) }\end{array}$} & \multirow{2}{*}{$\begin{array}{l}\text { Lith. } \\
\text { unit }\end{array}$} & \multicolumn{10}{|c|}{ Major element oxide (wt\%) } & \multirow{2}{*}{$\begin{array}{l}\mathrm{LOI} \\
\text { (wt\%) }\end{array}$} & \multirow[b]{2}{*}{ Total } \\
\hline & & & $\mathrm{SiO}_{2}$ & $\mathrm{Al}_{2} \mathrm{O}_{3}$ & $\mathrm{Fe}_{2} \mathrm{O}_{3}$ & $\mathrm{MnO}$ & $\mathrm{MgO}$ & $\mathrm{CaO}$ & $\mathrm{Na}_{2} \mathrm{O}$ & $\mathrm{K}_{2} \mathrm{O}$ & $\mathrm{TiO}_{2}$ & $\mathrm{P}_{2} \mathrm{O}_{5}$ & & \\
\hline \multicolumn{15}{|l|}{ 333-C0012C- } \\
\hline $1 \mathrm{H}-2,113.0-115.0$ & 2.40 & \multirow{18}{*}{ I } & 59.4 & 15.5 & 5.63 & 0.07 & 2.24 & 8.85 & 3.54 & 2.67 & 0.62 & 0.13 & 10.1 & 98.6 \\
\hline $1 \mathrm{H}-3,95.0-97.0$ & 3.54 & & 56.9 & 14.2 & 6.65 & 0.06 & 2.91 & 10.87 & 3.18 & 2.54 & 0.61 & 0.10 & 12.7 & 98.1 \\
\hline $2 \mathrm{H}-2,128.5-130.5$ & 7.06 & & 56.9 & 14.9 & 5.58 & 0.06 & 2.67 & 12.12 & 2.91 & 2.56 & 0.63 & 0.11 & 13.6 & 98.4 \\
\hline $2 \mathrm{H}-4,70.0-72.0$ & 9.16 & & 59.8 & 15.4 & 6.65 & 0.05 & 2.93 & 7.08 & 3.26 & 2.83 & 0.64 & 0.11 & 9.9 & 98.7 \\
\hline $2 \mathrm{H}-6,78.0-80.0$ & 11.92 & & 61.2 & 16.8 & 6.38 & 0.06 & 2.90 & 3.20 & 3.51 & 3.14 & 0.70 & 0.10 & 8.1 & 97.9 \\
\hline $3 \mathrm{H}-3,75.0-77.0$ & 17.36 & & 60.9 & 16.0 & 6.93 & 0.07 & 2.88 & 3.97 & 3.76 & 3.02 & 0.68 & 0.10 & 8.9 & 98.3 \\
\hline $4 \mathrm{H}-4,20.0-22.0$ & 27.68 & & 62.8 & 16.5 & 6.35 & 0.07 & 2.73 & 1.57 & 3.42 & 3.23 & 0.66 & 0.09 & 6.7 & 97.4 \\
\hline $5 \mathrm{H}-3,21.0-23.0$ & 35.94 & & 62.5 & 17.1 & 6.88 & 0.06 & 2.82 & 1.33 & 3.41 & 3.32 & 0.68 & 0.09 & 7.1 & 98.2 \\
\hline $6 \mathrm{H}-4,21.5-23.5$ & 46.66 & & 63.2 & 16.5 & 6.49 & 0.06 & 2.74 & 1.44 & 3.35 & 3.17 & 0.70 & 0.09 & 6.7 & 97.8 \\
\hline $7 \mathrm{H}-4,54.0-56.0$ & 55.16 & & 60.6 & 17.0 & 6.29 & 0.08 & 2.70 & 3.49 & 3.17 & 3.27 & 0.70 & 0.09 & 8.3 & 97.4 \\
\hline $8 \mathrm{H}-4,21.0-23.0$ & 64.15 & & 59.7 & 16.8 & 6.10 & 0.29 & 2.68 & 5.14 & 3.11 & 3.17 & 0.69 & 0.10 & 9.5 & 97.9 \\
\hline $9 \mathrm{H}-4,20.5-22.5$ & 73.97 & & 62.6 & 17.5 & 6.01 & 0.11 & 2.65 & 1.57 & 3.12 & 3.31 & 0.72 & 0.09 & 6.7 & 97.7 \\
\hline $10 \mathrm{H}-2,22.0-24.0$ & 80.41 & & 62.5 & 18.2 & 6.52 & 0.55 & 2.69 & 5.01 & 2.73 & 3.18 & 0.71 & 0.09 & 9.0 & 102.1 \\
\hline $11 \mathrm{H}-6,21.0-23.0$ & 91.71 & & 61.8 & 17.1 & 6.58 & 0.28 & 2.60 & 2.99 & 2.81 & 3.28 & 0.68 & 0.09 & 7.4 & 98.2 \\
\hline $12 \mathrm{H}-3,36.0-38.0$ & 96.89 & & 59.4 & 16.6 & 5.84 & 0.31 & 2.43 & 7.45 & 2.63 & 3.00 & 0.66 & 0.09 & 9.9 & 98.3 \\
\hline $13 \mathrm{H}-4,27.5-29.5$ & 105.33 & & 55.6 & 15.8 & 5.59 & 0.68 & 2.17 & 12.14 & 2.28 & 2.59 & 0.64 & 0.28 & 12.8 & 97.8 \\
\hline $14 \mathrm{H}-2,26.5-28.5$ & 108.56 & & 60.9 & 17.2 & 6.15 & 0.20 & 2.37 & 5.68 & 2.49 & 3.03 & 0.69 & 0.09 & 9.1 & 98.7 \\
\hline $15 \mathrm{H}-4,29.5-31.5$ & 119.56 & & 61.2 & 16.6 & 5.76 & 0.61 & 2.36 & 4.63 & 2.55 & 3.18 & 0.67 & 0.10 & 8.5 & 97.7 \\
\hline \multicolumn{15}{|l|}{ 333-C0012D- } \\
\hline $1 \mathrm{H}-2,19.0-21.0$ & 0.79 & & 57.2 & 14.1 & 5.88 & 0.06 & 2.64 & 10.95 & 3.11 & 2.51 & 0.53 & 0.10 & 12.1 & 97.1 \\
\hline $2 \mathrm{H}-3,26.5-28.5$ & 119.74 & & 62.2 & 16.8 & 5.80 & 0.18 & 2.42 & 3.75 & 2.61 & 3.23 & 0.66 & 0.08 & 7.7 & 97.8 \\
\hline $3 \mathrm{H}-3,28.5-30.5$ & 129.48 & & 62.1 & 17.0 & 5.89 & 0.22 & 2.49 & 3.51 & 2.71 & 3.11 & 0.68 & 0.10 & 7.7 & 97.9 \\
\hline $4 \mathrm{H}-4,29.5-31.5$ & 137.55 & & 64.9 & 16.7 & 6.34 & 0.12 & 2.45 & 1.06 & 2.70 & 3.35 & 0.68 & 0.09 & 5.4 & 98.4 \\
\hline $5 \mathrm{H}-5,30.0-32.0$ & 144.93 & & 64.8 & 16.4 & 6.14 & 0.14 & 2.40 & 0.85 & 2.48 & 3.35 & 0.67 & 0.08 & 5.1 & 97.4 \\
\hline $6 \mathrm{H}-6,18.0-20.0$ & 150.22 & & 63.3 & 16.6 & 6.42 & 0.19 & 2.50 & 1.98 & 2.38 & 3.26 & 0.69 & 0.09 & 5.8 & 97.5 \\
\hline $7 \mathrm{H}-3,29.0-31.0$ & 154.84 & \multirow{8}{*}{ II } & 63.9 & 17.1 & 6.70 & 0.10 & 2.61 & 1.05 & 2.58 & 3.03 & 0.69 & 0.08 & 5.3 & 97.8 \\
\hline $8 \mathrm{H}-4,29.5-31.5$ & 160.56 & & 64.3 & 17.0 & 5.85 & 0.11 & 2.52 & 1.59 & 2.58 & 3.44 & 0.70 & 0.10 & 6.0 & 98.1 \\
\hline $9 \mathrm{H}-3,62.0-64.0$ & 165.28 & & 64.9 & 17.1 & 5.92 & 0.21 & 2.48 & 0.84 & 2.34 & 3.47 & 0.68 & 0.09 & 5.0 & 98.1 \\
\hline $10 \mathrm{H}-3,31.0-33.0$ & 168.51 & & 64.1 & 16.6 & 6.05 & 0.18 & 2.47 & 1.56 & 2.46 & 3.37 & 0.67 & 0.09 & 5.6 & 97.5 \\
\hline $11 \mathrm{H}-2,30.0-32.0$ & 171.46 & & 65.1 & 16.7 & 5.86 & 0.11 & 2.36 & 1.13 & 2.57 & 3.28 & 0.68 & 0.08 & 4.9 & 97.9 \\
\hline $12 \mathrm{H}-1,70.0-72.0$ & 174.00 & & 63.3 & 16.7 & 5.29 & 0.07 & 1.69 & 4.52 & 3.25 & 1.38 & 0.64 & 0.11 & 3.8 & 97.0 \\
\hline $12 \mathrm{H}-3,12.0-14.0$ & 174.45 & & 60.7 & 15.1 & 5.44 & 0.74 & 2.13 & 7.79 & 2.44 & 2.95 & 0.60 & 0.14 & 9.7 & 98.1 \\
\hline $13 \mathrm{H}-4,31.0-33.0$ & 178.88 & & 62.3 & 16.8 & 5.68 & 0.10 & 2.18 & 4.88 & 2.92 & 2.35 & 0.73 & 0.10 & 6.8 & 98.0 \\
\hline \multicolumn{15}{|l|}{ 333-C0012E- } \\
\hline $1 \mathrm{X}-3,61.0-63.0$ & 503.08 & \multirow{4}{*}{$\mathrm{VI}$} & 55.3 & 14.6 & 6.73 & 0.48 & 3.25 & 12.57 & 1.40 & 2.61 & 0.52 & 0.19 & 12.6 & 97.7 \\
\hline $3 X-2,61.0-63.0$ & 521.03 & & 49.7 & 13.6 & 5.72 & 0.38 & 2.66 & 21.55 & 1.05 & 2.94 & 0.46 & 0.16 & 17.5 & 98.3 \\
\hline $3 X-6,59.5-61.5$ & 524.67 & & 51.9 & 13.5 & 9.34 & 1.90 & 2.69 & 13.18 & 1.24 & 4.15 & 0.48 & 0.30 & 12.3 & 98.7 \\
\hline $3 X-8,66.0-68.0$ & 526.77 & & 50.5 & 15.2 & 10.3 & 0.28 & 7.45 & 9.97 & 3.18 & 0.59 & 1.26 & 0.16 & 1.3 & 98.9 \\
\hline \multicolumn{15}{|l|}{ 333-C0012F- } \\
\hline $2 \mathrm{R}-1,64.0-66.0$ & 523.15 & & 50.8 & 14.7 & 10.4 & 0.25 & 7.46 & 8.84 & 3.42 & 1.04 & 1.25 & 0.16 & 1.7 & 98.3 \\
\hline \multicolumn{15}{|l|}{ 333-C0012G- } \\
\hline $1 \mathrm{R}-3,49.0-51.0$ & 517.09 & & 54.4 & 14.5 & 9.57 & 0.42 & 3.20 & 9.91 & 1.20 & 3.28 & 0.65 & 0.16 & 11.3 & 97.3 \\
\hline $2 \mathrm{R}-2,134.0-136.0$ & 526.24 & & 53.1 & 12.9 & 9.81 & 0.20 & 7.78 & 7.48 & 2.46 & 3.44 & 1.18 & 0.15 & 1.7 & 98.5 \\
\hline $4 R-1,29.5-31.5$ & 543.81 & & 54.4 & 14.2 & 11.2 & 0.16 & 6.83 & 6.04 & 4.74 & 1.48 & 1.64 & 0.19 & 2.1 & 100.9 \\
\hline $5 R-1,4.0-6.0$ & 553.05 & & 52.0 & 13.4 & 11.3 & 0.17 & 7.92 & 6.37 & 4.08 & 1.69 & 1.64 & 0.18 & 2.5 & 98.8 \\
\hline $6 \mathrm{R}-\mathrm{CC}, 7.0-9.0$ & 563.32 & VII & 49.5 & 16.5 & 10.4 & 0.19 & 5.36 & 9.30 & 4.83 & 1.24 & 1.38 & 0.14 & 5.3 & 98.8 \\
\hline 7R-1, 29.0-31.0 & 572.30 & & 49.2 & 13.7 & 13.8 & 0.23 & 6.52 & 8.17 & 4.68 & 0.72 & 1.53 & 0.16 & 3.8 & 98.7 \\
\hline $8 R-1,34.0-36.0$ & 581.85 & & 49.9 & 15.9 & 10.3 & 0.18 & 6.29 & 9.67 & 4.78 & 0.41 & 1.48 & 0.16 & 4.3 & 99.1 \\
\hline 10R-2, 118.0-120.0 & 597.48 & & 50.8 & 13.6 & 11.9 & 0.28 & 5.91 & 8.30 & 3.02 & 2.98 & 1.61 & 0.19 & 2.1 & 98.6 \\
\hline $12 \mathrm{R}-2,91.0-93.0$ & 612.93 & & 50.8 & 14.3 & 11.1 & 0.23 & 5.99 & 8.50 & 2.60 & 3.28 & 1.55 & 0.16 & 2.0 & 98.5 \\
\hline $13 R-1,121.0-123.0$ & 616.72 & & 48.6 & 14.7 & 12.8 & 0.25 & 6.19 & 8.78 & 2.80 & 2.84 & 1.56 & 0.17 & 3.8 & 98.6 \\
\hline $14 \mathrm{R}-1,22.0-24.0$ & 620.73 & & 51.2 & 15.7 & 9.28 & 0.22 & 6.31 & 9.70 & 3.84 & 0.93 & 1.70 & 0.18 & 2.2 & 99.0 \\
\hline $15 \mathrm{R}-1,29.0-31.0$ & 625.80 & & 49.1 & 15.8 & 9.35 & 0.14 & 8.20 & 9.81 & 4.50 & 0.68 & 0.87 & 0.11 & 5.4 & 98.6 \\
\hline
\end{tabular}

$\mathrm{LOI}=$ loss on ignition. 
Table T4. Distribution of calcareous nannofossils, Holes C0012C, C0012D, and C0012E.

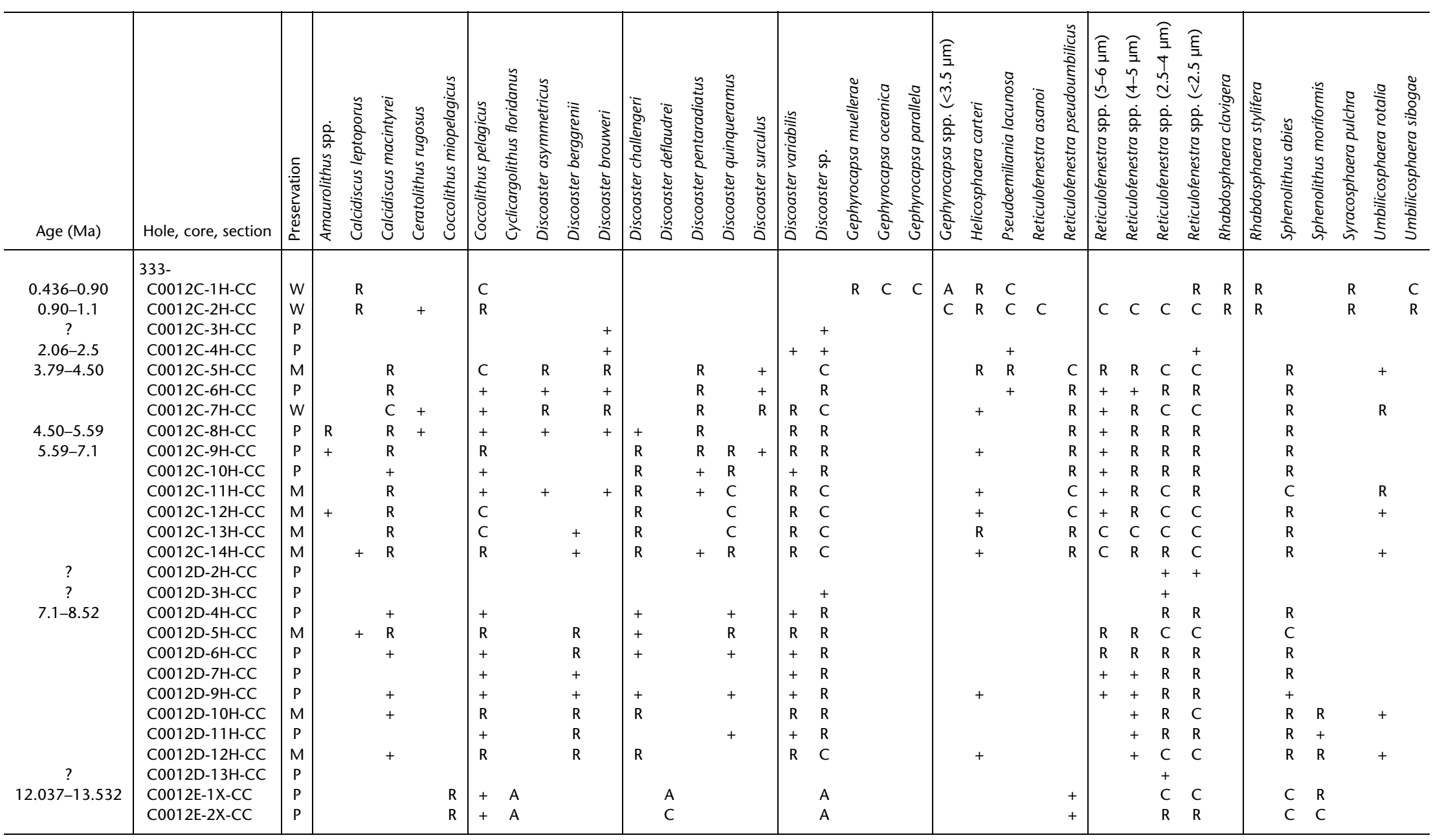

Preservation: $\mathrm{P}=$ poor, $\mathrm{M}=$ moderate, $\mathrm{W}=$ well. Abundance: $\mathrm{A}=$ abundant, $\mathrm{C}=$ common, $\mathrm{R}=$ rare, $+=$ present. Barren: $333-\mathrm{C} 0012 \mathrm{C}-15 \mathrm{H}-\mathrm{CC}, \mathrm{C} 0012 \mathrm{D}-8 \mathrm{H}-\mathrm{CC}, \mathrm{C} 0012 \mathrm{E}-3 \mathrm{X}-\mathrm{CC}$. 
Table T5. Calcareous nannofossils events and absolute age, Holes C0012C and C0012D.

\begin{tabular}{|c|c|c|c|c|c|c|c|c|c|c|c|}
\hline \multirow[b]{2}{*}{ Calcareous nannofossil event } & \multicolumn{4}{|c|}{ Age (Ma) } & \multicolumn{2}{|c|}{ Hole, core, section } & \multicolumn{4}{|c|}{ Depth (mbsf) } & \multirow{2}{*}{$\begin{array}{l}\text { Sedimentation } \\
\text { rate }(\mathrm{cm} / \mathrm{k} \text {.y. })\end{array}$} \\
\hline & Upper & Lower & Middle & Error & Top & Bottom & Top & Bottom & Middle & Error & \\
\hline & & & & & $333-$ & $333-$ & & & & & \\
\hline LO Reticulofenestra asanoi & 0.901 & 0.905 & 0.903 & 0.002 & $\mathrm{C} 0012 \mathrm{C}-1 \mathrm{H}-\mathrm{CC}$ & $\mathrm{C} 0012 \mathrm{C}-2 \mathrm{H}-\mathrm{CC}$ & 4.495 & 13.849 & 9.172 & 4.677 & 1.02 \\
\hline LO Discoaster brouweri & 2.06 & 2.06 & 2.06 & 0 & $\mathrm{C} 0012 \mathrm{C}-2 \mathrm{H}-\mathrm{CC}$ & $\mathrm{C} 0012 \mathrm{C}-4 \mathrm{H}-\mathrm{CC}$ & 13.896 & 32.853 & 23.4245 & 9.5285 & 1.23 \\
\hline LO Reticulofenestra pseudoumbilicus & 3.79 & 3.79 & 3.79 & 0 & $\mathrm{C} 0012 \mathrm{C}-4 \mathrm{H}-\mathrm{CC}$ & $\mathrm{C} 0012 \mathrm{C}-5 \mathrm{H}-\mathrm{CC}$ & 33 & 42.195 & 37.0975 & 4.5975 & 0.82 \\
\hline FO Amaurolithus spp. & 4.5 & 4.5 & 4.5 & 0 & $\mathrm{C} 0012 \mathrm{C}-7 \mathrm{H}-\mathrm{CC}$ & $\mathrm{C} 0012 \mathrm{C}-8 \mathrm{H}-\mathrm{CC}$ & 60.995 & 69.128 & 65.0615 & 4.0665 & 3.87 \\
\hline LO Discoaster quinqueramus & 5.59 & 5.59 & 5.59 & 0 & $\mathrm{C} 0012 \mathrm{C}-8 \mathrm{H}-\mathrm{CC}$ & $\mathrm{C} 0012 \mathrm{C}-9 \mathrm{H}-\mathrm{CC}$ & 69.175 & 78.855 & 74.065 & 4.89 & 0.83 \\
\hline PE Reticulofenestra pseudoumbilicus (>7 $\mu \mathrm{m})$ & 7.077 & 7.167 & 7.122 & 0.045 & C0012C-14H-CC & $\mathrm{C} 0012 \mathrm{D}-4 \mathrm{H}-\mathrm{CC}$ & 116 & 140.858 & 128.479 & 12.479 & 3.55 \\
\hline
\end{tabular}

Age based on Raffi et al. (2006). LO = last occurrence, FO = first occurrence, PE = paracme end. 
Table T6. Paleomagnetic age datums, Site C0012.

\begin{tabular}{|c|c|c|c|c|c|c|}
\hline \multirow[b]{2}{*}{ Datum } & \multirow[b]{2}{*}{$\begin{array}{l}\text { Boundary } \\
\text { age (Ma) }\end{array}$} & \multicolumn{2}{|c|}{ Upper } & \multicolumn{2}{|c|}{ Lower } & \multirow{2}{*}{$\begin{array}{c}\text { Average } \\
\text { depth } \\
\text { (mbsf) }\end{array}$} \\
\hline & & $\begin{array}{l}\text { Core, section, } \\
\text { interval }(\mathrm{cm})\end{array}$ & $\begin{array}{l}\text { Depth } \\
\text { (mbsf) }\end{array}$ & $\begin{array}{l}\text { Core, section, } \\
\text { interval }(\mathrm{cm})\end{array}$ & $\begin{array}{l}\text { Depth } \\
\text { (mbsf) }\end{array}$ & \\
\hline Magnetic & & 333-C0012C- & & 333-C0012C- & & \\
\hline Brunhes/Matuyama & 0.78 & $2 \mathrm{H}-1,27$ & 4.76 & $2 \mathrm{H}-1,87$ & 5.32 & 5.04 \\
\hline Jaramillo top & 0.99 & $2 \mathrm{H}-2,38$ & 6.20 & $2 \mathrm{H}-2,88$ & 6.67 & 6.43 \\
\hline Jaramillo base & 1.07 & $2 \mathrm{H}-4,22$ & 8.70 & $2 \mathrm{H}-4,90$ & 9.34 & 9.02 \\
\hline Cobb Mountain & $1.173-1.185$ & & & & & \\
\hline Olduvai top & 1.78 & & & & & \\
\hline Olduvai base & 1.95 & & & & & \\
\hline Matuyama/Gauss & 2.85 & & & & & \\
\hline Keana top & 3.03 & & & & & \\
\hline Keana base & 3.12 & & & & & \\
\hline Mammoth top & 3.21 & & & & & \\
\hline Mammoth base & 3.33 & & & & & \\
\hline Gauss/Gilbert & 3.60 & $3 \mathrm{H}-3,88$ & 17.47 & $3 \mathrm{H}-4,88$ & 18.81 & 18.14 \\
\hline Cochiti top & 4.19 & $7 \mathrm{H}-2,35$ & 53.52 & $7 \mathrm{H}-5,55$ & 56.38 & 54.95 \\
\hline Cochiti base & 4.30 & $8 \mathrm{H}-3,10$ & 62.73 & $8 \mathrm{H}-3,112$ & 63.68 & 63.20 \\
\hline Nunivak top & 4.49 & $9 \mathrm{H}-6,90$ & 76.36 & $9 \mathrm{H}-7,90$ & 77.80 & 77.08 \\
\hline Nunivak base & 4.63 & & & & & \\
\hline Sidufjall top & 4.80 & & & & & \\
\hline Sidufjall base & 4.90 & & & & & \\
\hline Thvera top & 5.00 & & & & & \\
\hline Thvera base & 5.24 & $10 \mathrm{H}-9,10$ & 85.16 & $11 \mathrm{H}-1,19$ & 86.68 & 85.92 \\
\hline Gilbert/C3An.1n & 6.03 & $13 \mathrm{H}-1,19$ & 102.19 & $13 \mathrm{H}-1,91$ & 102.91 & 102.55 \\
\hline C3An.1n/C3An.1r & 6.25 & $14 \mathrm{H}-1,30$ & 108.27 & $14 \mathrm{H}-3,25$ & 108.80 & 108.53 \\
\hline C3An.1r/C3An.2n & 6.44 & $14 \mathrm{H}-4,96$ & 110.17 & $14 \mathrm{H}-5,20$ & 110.76 & 110.46 \\
\hline C3An.2n/C3Ar & 6.73 & $14 \mathrm{H}-7,13$ & 113.25 & $14 \mathrm{H}-7,89$ & 113.94 & 113.60 \\
\hline $\mathrm{C} 3 \mathrm{Ar} / \mathrm{C} 3 \mathrm{Bn}$ & 7.14 & $\begin{array}{c}333-\mathrm{C} 0012 \mathrm{D}- \\
2 \mathrm{H}-7,90\end{array}$ & 123.34 & $\begin{array}{c}333-\mathrm{C} 0012 \mathrm{D}- \\
2 \mathrm{H}-8,15\end{array}$ & 123.93 & 123.63 \\
\hline $\mathrm{C} 3 \mathrm{Bn} / \mathrm{C} 3 \mathrm{Br} .1 \mathrm{r}$ & 7.21 & & & & & \\
\hline C3Br.1r/C3Br.1n & 7.25 & & & & & \\
\hline C3Br.1n/C3Br.2r & 7.29 & & & & & \\
\hline $\mathrm{C} 3 \mathrm{Br} .2 \mathrm{r} / \mathrm{C} 3 \mathrm{Br} .2 \mathrm{n}$ & 7.45 & $3 \mathrm{H}-4,90.5$ & 130.35 & $3 \mathrm{H}-4,90.5$ & 130.35 & 130.35 \\
\hline $\mathrm{C} 3 \mathrm{Br} .2 \mathrm{n} / \mathrm{C} 3 \mathrm{Br} \cdot 3 \mathrm{r}$ & 7.49 & & & & & \\
\hline C3Br.3r/C4n.1n & 7.53 & & & & & \\
\hline C $4 n .1 n / C 4 n .1 r$ & 7.64 & $4 \mathrm{H}-5,67$ & 138.11 & $4 \mathrm{H}-6,20$ & 138.90 & 138.51 \\
\hline C $4 n .1 r / C 4 n .2 n$ & 7.70 & $5 \mathrm{H}-2,30$ & 142.71 & $5 \mathrm{H}-3,48$ & 144.31 & 143.51 \\
\hline C $4 n .2 n / C 4 r .1 r$ & 8.11 & $11 \mathrm{H}-3,31$ & 172.52 & $11 \mathrm{H}-4,67$ & 173.67 & 173.09 \\
\hline Tephra & & 333-C0012C- & & 333-C0012C- & & \\
\hline Azuki volcanic ash bed & 0.85 & $2 \mathrm{H}-1,118$ & 5.61 & $2 \mathrm{H}-1,132$ & 5.75 & 5.68 \\
\hline Pink volcanic ash bed & 1.05 & $2 \mathrm{H}-3,40$ & 7.54 & $2 \mathrm{H}-3,73$ & 7.85 & 7.70 \\
\hline Ohta volcanic ash bed & 3.9 & $6 \mathrm{H}-2,120$ & 44.93 & $6 \mathrm{H}-2,124.5$ & 44.97 & 44.95 \\
\hline
\end{tabular}


Table T7. Moisture and density results from discrete samples, Site C0012. (Continued on next four pages.)

\begin{tabular}{|c|c|c|c|c|c|c|c|}
\hline \multirow{2}{*}{$\begin{array}{l}\text { Hole, core, section, } \\
\text { interval }(\mathrm{cm})\end{array}$} & \multirow{2}{*}{$\begin{array}{l}\text { Depth CSF } \\
(\mathrm{m})\end{array}$} & \multirow{2}{*}{$\begin{array}{l}\text { Water content } \\
\quad(w t \%)\end{array}$} & \multicolumn{2}{|c|}{ Density $\left(\mathrm{g} / \mathrm{cm}^{3}\right)$} & \multirow{2}{*}{$\begin{array}{c}\text { Porosity } \\
\text { (fractional) }\end{array}$} & \multirow[b]{2}{*}{ Void ratio } & \multirow[b]{2}{*}{ Lithologic note } \\
\hline & & & Bulk & Grain & & & \\
\hline \multicolumn{8}{|l|}{$333-$} \\
\hline C0012D-1H-1, 24.5 & 0.25 & 0.46 & 1.51 & 2.57 & 0.68 & 2.14 & \\
\hline $\mathrm{C} 0012 \mathrm{C}-1 \mathrm{H}-1,49$ & 0.49 & 0.50 & 1.47 & 2.60 & 0.72 & 2.57 & \\
\hline C0012D-1H-2, 19 & 0.80 & 0.48 & 1.49 & 2.60 & 0.70 & 2.38 & \\
\hline C0012C-1H-1, 119 & 1.19 & 0.49 & 1.48 & 2.55 & 0.70 & 2.34 & \\
\hline $\mathrm{C} 0012 \mathrm{C}-1 \mathrm{H}-2,39$ & 1.80 & 0.48 & 1.49 & 2.58 & 0.70 & 2.33 & \\
\hline C0012C-1H-2, 90 & 2.31 & 0.47 & 1.39 & 2.04 & 0.64 & 1.79 & \\
\hline $\mathrm{C} 0012 \mathrm{C}-1 \mathrm{H}-3,39$ & 3.19 & 0.42 & 1.59 & 2.70 & 0.66 & 1.95 & \\
\hline $\mathrm{C} 0012 \mathrm{C}-1 \mathrm{H}-3,102$ & 3.82 & 0.47 & 1.51 & 2.63 & 0.70 & 2.28 & \\
\hline C0012C-1H-4, 11.5 & 4.33 & 0.46 & 1.54 & 2.71 & 0.69 & 2.23 & \\
\hline C0012C-2H-1, 29 & 4.79 & 0.47 & 1.50 & 2.55 & 0.69 & 2.21 & \\
\hline $\mathrm{C} 0012 \mathrm{C}-2 \mathrm{H}-1,105$ & 5.55 & 0.47 & 1.51 & 2.60 & 0.69 & 2.27 & \\
\hline $\mathrm{C} 0012 \mathrm{C}-2 \mathrm{H}-2,29$ & 6.21 & 0.46 & 1.54 & 2.70 & 0.69 & 2.25 & \\
\hline $\mathrm{C} 0012 \mathrm{C}-2 \mathrm{H}-2,104.5$ & 6.96 & 0.46 & 1.53 & 2.65 & 0.69 & 2.21 & \\
\hline $\mathrm{C} 0012 \mathrm{C}-2 \mathrm{H}-3,29$ & 7.61 & 0.43 & 1.58 & 2.70 & 0.66 & 1.98 & \\
\hline C0012C-2H-4, 28 & 9.01 & 0.44 & 1.57 & 2.74 & 0.68 & 2.13 & \\
\hline $\mathrm{C} 0012 \mathrm{C}-2 \mathrm{H}-4,74$ & 9.47 & 0.44 & 1.56 & 2.68 & 0.67 & 2.07 & \\
\hline $\mathrm{C} 0012 \mathrm{C}-2 \mathrm{H}-5,29$ & 10.43 & 0.45 & 1.58 & 2.77 & 0.68 & 2.17 & \\
\hline C0012C-2H-5, 116 & 11.30 & 0.48 & 1.50 & 2.67 & 0.71 & 2.44 & \\
\hline $\mathrm{C} 0012 \mathrm{C}-2 \mathrm{H}-6,29$ & 11.86 & 0.49 & 1.49 & 2.67 & 0.72 & 2.51 & \\
\hline $\mathrm{C} 0012 \mathrm{C}-2 \mathrm{H}-6,82$ & 12.39 & 0.50 & 1.50 & 2.82 & 0.73 & 2.77 & \\
\hline $\mathrm{C} 0012 \mathrm{C}-2 \mathrm{H}-7,30$ & 13.27 & 0.49 & 1.50 & 2.73 & 0.72 & 2.60 & \\
\hline C0012C-2H-7, 99 & 13.96 & 0.52 & 1.46 & 2.70 & 0.74 & 2.88 & \\
\hline $\mathrm{C} 0012 \mathrm{C}-3 \mathrm{H}-1,28$ & 14.28 & 0.53 & 1.45 & 2.71 & 0.75 & 3.00 & \\
\hline $\mathrm{C} 0012 \mathrm{C}-3 \mathrm{H}-1,90$ & 14.90 & 0.51 & 1.49 & 2.80 & 0.74 & 2.82 & \\
\hline $\mathrm{C} 0012 \mathrm{C}-3 \mathrm{H}-2,28$ & 15.69 & 0.53 & 1.44 & 2.69 & 0.75 & 2.98 & \\
\hline $\mathrm{C} 0012 \mathrm{C}-3 \mathrm{H}-2,91$ & 16.32 & 0.49 & 1.50 & 2.67 & 0.71 & 2.47 & \\
\hline C0012C-3H-3, 27 & 17.08 & 0.54 & 1.44 & 2.76 & 0.76 & 3.13 & \\
\hline $\mathrm{C} 0012 \mathrm{C}-3 \mathrm{H}-3,79$ & 17.60 & 0.50 & 1.50 & 2.80 & 0.73 & 2.70 & \\
\hline C0012C-3H-4, 27 & 18.51 & 0.49 & 1.50 & 2.70 & 0.72 & 2.53 & \\
\hline C0012C-3H-5, 1 & 19.67 & 0.51 & 1.48 & 2.78 & 0.74 & 2.87 & \\
\hline C0012C-3H-5, 67 & 20.33 & 0.48 & 1.50 & 2.62 & 0.70 & 2.35 & \\
\hline C0012C-3H-6, 28 & 21.36 & 0.44 & 1.55 & 2.62 & 0.67 & 2.04 & \\
\hline $\mathrm{C} 0012 \mathrm{C}-3 \mathrm{H}-6,97$ & 22.05 & 0.47 & 1.50 & 2.58 & 0.69 & 2.25 & \\
\hline C0012C-3H-7, 28 & 22.76 & 0.47 & 1.49 & 2.49 & 0.68 & 2.14 & \\
\hline C0012C-3H-7, 98 & 23.46 & 0.46 & 1.52 & 2.60 & 0.69 & 2.19 & \\
\hline C0012C-4H-1, 28 & 23.78 & 0.48 & 1.51 & 2.67 & 0.71 & 2.41 & \\
\hline $\mathrm{C} 0012 \mathrm{C}-4 \mathrm{H}-1,103$ & 24.53 & 0.50 & 1.51 & 2.88 & 0.74 & 2.81 & \\
\hline $\mathrm{C} 0012 \mathrm{C}-4 \mathrm{H}-2,33$ & 25.25 & 0.49 & 1.49 & 2.62 & 0.71 & 2.42 & \\
\hline $\mathrm{C} 0012 \mathrm{C}-4 \mathrm{H}-2,122$ & 26.14 & 0.50 & 1.49 & 2.74 & 0.73 & 2.68 & \\
\hline C0012C-4H-3, 2 & 26.35 & 0.51 & 1.47 & 2.72 & 0.74 & 2.80 & \\
\hline C0012C-4H-3, 67 & 27.00 & 0.48 & 1.47 & 2.47 & 0.69 & 2.24 & \\
\hline C0012C-4H-5, 24 & 28.22 & 0.50 & 1.46 & 2.53 & 0.71 & 2.46 & \\
\hline $\mathrm{C} 0012 \mathrm{C}-4 \mathrm{H}-5,98$ & 28.96 & 0.49 & 1.50 & 2.72 & 0.72 & 2.57 & \\
\hline C0012C-4H-6, 28 & 29.47 & 0.51 & 1.46 & 2.59 & 0.72 & 2.58 & \\
\hline C0012C-4H-6, 98 & 30.17 & 0.50 & 1.45 & 2.49 & 0.71 & 2.40 & \\
\hline C0012C-4H-7, 23 & 30.84 & 0.50 & 1.44 & 2.44 & 0.71 & 2.43 & \\
\hline C0012C-4H-7, 97 & 31.58 & 0.48 & 1.51 & 2.66 & 0.70 & 2.35 & \\
\hline C0012C-4H-8, 23 & 32.26 & 0.47 & 1.51 & 2.56 & 0.69 & 2.18 & \\
\hline $\mathrm{C} 0012 \mathrm{C}-4 \mathrm{H}-8,98$ & 33.01 & 0.48 & 1.52 & 2.80 & 0.72 & 2.56 & \\
\hline C0012C-5H-1, 36 & 33.36 & 0.48 & 1.50 & 2.64 & 0.70 & 2.38 & \\
\hline $\mathrm{C} 0012 \mathrm{C}-5 \mathrm{H}-1,128$ & 34.28 & 0.52 & 1.46 & 2.64 & 0.73 & 2.75 & \\
\hline C0012C-5H-2, 22 & 34.62 & 0.50 & 1.44 & 2.42 & 0.70 & 2.38 & \\
\hline $\mathrm{C} 0012 \mathrm{C}-5 \mathrm{H}-2,82$ & 35.22 & 0.44 & 1.54 & 2.57 & 0.67 & 1.99 & \\
\hline C0012C-5H-4, 12 & 36.17 & 0.50 & 1.45 & 2.50 & 0.71 & 2.45 & \\
\hline C0012C-5H-4, 124 & 37.29 & 0.48 & 1.53 & 2.80 & 0.72 & 2.51 & \\
\hline C0012C-5H-5, 35 & 37.86 & 0.51 & 1.44 & 2.54 & 0.72 & 2.63 & \\
\hline C0012C-5H-5, 112 & 38.63 & 0.49 & 1.47 & 2.59 & 0.71 & 2.48 & \\
\hline $\mathrm{C} 0012 \mathrm{C}-5 \mathrm{H}-6,32$ & 39.24 & 0.47 & 1.53 & 2.67 & 0.69 & 2.27 & \\
\hline C0012C-5H-6, 112 & 40.04 & 0.47 & 1.54 & 2.80 & 0.71 & 2.44 & \\
\hline C0012C-5H-7, 25 & 40.58 & 0.50 & 1.49 & 2.71 & 0.72 & 2.62 & \\
\hline C0012C-5H-7, 98 & 41.31 & 0.48 & 1.49 & 2.63 & 0.71 & 2.41 & \\
\hline C0012C-5H-8, 34 & 42.08 & 0.50 & 1.52 & 2.91 & 0.74 & 2.79 & \\
\hline C0012C-6H-1, 38 & 42.88 & 0.50 & 1.50 & 2.77 & 0.73 & 2.69 & \\
\hline C0012C-6H-1, 101 & 43.51 & 0.50 & 1.47 & 2.63 & 0.72 & 2.60 & \\
\hline C0012C-6H-2, 14 & 44.06 & 0.49 & 1.49 & 2.63 & 0.71 & 2.42 & \\
\hline C0012C-6H-2, 79 & 44.71 & 0.49 & 1.49 & 2.60 & 0.70 & 2.39 & \\
\hline $\mathrm{C} 0012 \mathrm{C}-6 \mathrm{H}-2,83$ & 44.75 & 0.51 & 1.44 & 2.47 & 0.71 & 2.50 & \\
\hline
\end{tabular}


Table T7 (continued). (Continued on next page.)

\begin{tabular}{|c|c|c|c|c|c|c|c|}
\hline \multirow{2}{*}{$\begin{array}{l}\text { Hole, core, section, } \\
\text { interval }(\mathrm{cm})\end{array}$} & \multirow{2}{*}{$\begin{array}{l}\text { Depth CSF } \\
(\mathrm{m})\end{array}$} & \multirow{2}{*}{$\begin{array}{l}\text { Water content } \\
\quad(\text { wt } \%)\end{array}$} & \multicolumn{2}{|c|}{ Density $\left(\mathrm{g} / \mathrm{cm}^{3}\right)$} & \multirow{2}{*}{$\begin{array}{c}\text { Porosity } \\
\text { (fractional) }\end{array}$} & \multirow[b]{2}{*}{ Void ratio } & \multirow[b]{2}{*}{ Lithologic note } \\
\hline & & & Bulk & Grain & & & \\
\hline C0012C-6H-2, 133 & 45.25 & 0.47 & 1.54 & 2.75 & 0.70 & 2.35 & \\
\hline $\mathrm{C} 0012 \mathrm{C}-6 \mathrm{H}-3,17$ & 45.51 & 0.50 & 1.48 & 2.68 & 0.72 & 2.61 & \\
\hline $\mathrm{C} 0012 \mathrm{C}-6 \mathrm{H}-3,110$ & 46.44 & 0.48 & 1.51 & 2.74 & 0.72 & 2.52 & \\
\hline C0012C-6H-5, 20 & 47.19 & 0.47 & 1.52 & 2.62 & 0.69 & 2.25 & \\
\hline $\mathrm{C} 0012 \mathrm{C}-6 \mathrm{H}-5,114$ & 48.13 & 0.46 & 1.53 & 2.63 & 0.69 & 2.19 & \\
\hline $\mathrm{C} 0012 \mathrm{C}-6 \mathrm{H}-6,10$ & 48.51 & 0.48 & 1.48 & 2.54 & 0.70 & 2.30 & \\
\hline C0012C-6H-6, 115 & 49.56 & 0.48 & 1.49 & 2.58 & 0.70 & 2.31 & \\
\hline C0012C-6H-6, 126.5 & 49.67 & 0.48 & 1.49 & 2.58 & 0.70 & 2.34 & \\
\hline C0012C-6H-7, 13 & 49.96 & 0.48 & 1.49 & 2.59 & 0.70 & 2.38 & \\
\hline C0012C-6H-7, 116 & 50.99 & 0.49 & 1.52 & 2.86 & 0.73 & 2.71 & \\
\hline $\mathrm{C} 0012 \mathrm{C}-6 \mathrm{H}-8,9$ & 51.33 & 0.48 & 1.51 & 2.65 & 0.70 & 2.35 & \\
\hline $\mathrm{C} 0012 \mathrm{C}-6 \mathrm{H}-8,29$ & 51.53 & 0.47 & 1.54 & 2.73 & 0.70 & 2.33 & \\
\hline $\mathrm{C} 0012 \mathrm{C}-6 \mathrm{H}-8,90$ & 52.14 & 0.48 & 1.50 & 2.60 & 0.70 & 2.30 & \\
\hline $\mathrm{C} 0012 \mathrm{C}-6 \mathrm{H}-8,94$ & 52.18 & 0.47 & 1.51 & 2.60 & 0.69 & 2.21 & \\
\hline $\mathrm{C} 0012 \mathrm{C}-8 \mathrm{H}-1,97$ & 60.97 & 0.49 & 1.48 & 2.58 & 0.71 & 2.40 & \\
\hline $\mathrm{C} 0012 \mathrm{C}-8 \mathrm{H}-1,125$ & 61.25 & 0.50 & 1.49 & 2.74 & 0.73 & 2.67 & \\
\hline $\mathrm{C} 0012 \mathrm{C}-8 \mathrm{H}-2,30$ & 61.71 & 0.46 & 1.50 & 2.47 & 0.67 & 2.06 & \\
\hline $\mathrm{C} 0012 \mathrm{C}-8 \mathrm{H}-2,118$ & 62.59 & 0.48 & 1.51 & 2.74 & 0.71 & 2.50 & \\
\hline $\mathrm{C} 0012 \mathrm{C}-8 \mathrm{H}-2,121.5$ & 62.63 & 0.49 & 1.47 & 2.55 & 0.71 & 2.40 & \\
\hline $\mathrm{C} 0012 \mathrm{C}-8 \mathrm{H}-3,43$ & 63.27 & 0.48 & 1.48 & 2.53 & 0.69 & 2.27 & \\
\hline $\mathrm{C} 0012 \mathrm{C}-8 \mathrm{H}-3,98$ & 63.82 & 0.49 & 1.52 & 2.89 & 0.73 & 2.77 & \\
\hline $\mathrm{C} 0012 \mathrm{C}-8 \mathrm{H}-5,18$ & 64.66 & 0.47 & 1.54 & 2.74 & 0.70 & 2.34 & \\
\hline C0012C-8H-5, 113 & 65.61 & 0.46 & 1.53 & 2.64 & 0.69 & 2.18 & \\
\hline $\mathrm{C} 0012 \mathrm{C}-8 \mathrm{H}-6,13$ & 66.01 & 0.48 & 1.51 & 2.69 & 0.71 & 2.41 & \\
\hline $\mathrm{C} 0012 \mathrm{C}-8 \mathrm{H}-6,100$ & 66.88 & 0.46 & 1.55 & 2.75 & 0.70 & 2.30 & \\
\hline $\mathrm{C} 0012 \mathrm{C}-8 \mathrm{H}-7,20$ & 67.49 & 0.48 & 1.48 & 2.54 & 0.70 & 2.33 & \\
\hline C0012C-8H-7, 107 & 68.36 & 0.47 & 1.49 & 2.51 & 0.68 & 2.17 & \\
\hline $\mathrm{C} 0012 \mathrm{C}-8 \mathrm{H}-8,26$ & 68.96 & 0.41 & 1.58 & 2.50 & 0.62 & 1.66 & \\
\hline $\mathrm{C} 0012 \mathrm{C}-8 \mathrm{H}-8,80$ & 69.50 & 0.48 & 1.49 & 2.54 & 0.69 & 2.26 & \\
\hline $\mathrm{C} 0012 \mathrm{C}-9 \mathrm{H}-1,80$ & 70.30 & 0.49 & 1.48 & 2.58 & 0.71 & 2.40 & \\
\hline C0012C-9H-1, 116 & 70.66 & 0.45 & 1.55 & 2.69 & 0.68 & 2.16 & \\
\hline $\mathrm{C} 0012 \mathrm{C}-9 \mathrm{H}-2,21$ & 71.16 & 0.47 & 1.52 & 2.66 & 0.70 & 2.31 & \\
\hline C0012C-9H-2, 118 & 72.13 & 0.43 & 1.58 & 2.70 & 0.67 & 1.99 & \\
\hline $\mathrm{C} 0012 \mathrm{C}-9 \mathrm{H}-3,25$ & 72.62 & 0.44 & 1.56 & 2.64 & 0.67 & 2.04 & \\
\hline $\mathrm{C} 0012 \mathrm{C}-9 \mathrm{H}-3,99$ & 73.36 & 0.46 & 1.54 & 2.74 & 0.70 & 2.30 & \\
\hline $\mathrm{C} 0012 \mathrm{C}-9 \mathrm{H}-5,24$ & 74.27 & 0.49 & 1.51 & 2.76 & 0.72 & 2.56 & \\
\hline C0012C-9H-5, 105 & 75.08 & 0.43 & 1.58 & 2.69 & 0.67 & 2.01 & \\
\hline C0012C-9H-6, 22 & 75.68 & 0.48 & 1.51 & 2.70 & 0.71 & 2.45 & \\
\hline $\mathrm{C} 0012 \mathrm{C}-9 \mathrm{H}-6,66$ & 76.12 & 0.44 & 1.53 & 2.51 & 0.66 & 1.91 & \\
\hline $\mathrm{C} 0012 \mathrm{C}-9 \mathrm{H}-7,50$ & 77.40 & 0.45 & 1.55 & 2.62 & 0.67 & 2.06 & \\
\hline C0012C-9H-7, 100 & 77.90 & 0.37 & 1.68 & 2.68 & 0.60 & 1.52 & \\
\hline $\mathrm{C} 0012 \mathrm{C}-9 \mathrm{H}-8,35$ & 78.66 & 0.37 & 1.67 & 2.66 & 0.61 & 1.54 & \\
\hline C0012C-10H-1, 20 & 79.20 & 0.42 & 1.58 & 2.59 & 0.64 & 1.81 & \\
\hline C0012C-10H-2, 20 & 80.62 & 0.43 & 1.51 & 2.34 & 0.63 & 1.69 & \\
\hline C0012C-10H-2, 98 & 81.40 & 0.46 & 1.51 & 2.49 & 0.67 & 2.03 & \\
\hline $\mathrm{C} 0012 \mathrm{C}-10 \mathrm{H}-5,42$ & 82.73 & 0.40 & 1.62 & 2.66 & 0.63 & 1.74 & \\
\hline C0012C-10H-6, 30 & 83.58 & 0.38 & 1.69 & 2.79 & 0.62 & 1.66 & \\
\hline C0012C-10H-6, 98 & 84.26 & 0.35 & 1.72 & 2.75 & 0.59 & 1.46 & \\
\hline C0012C-10H-8, 21 & 85.12 & 0.40 & 1.63 & 2.68 & 0.63 & 1.72 & \\
\hline C0012C-10H-8, 91 & 85.82 & 0.33 & 1.75 & 2.72 & 0.57 & 1.33 & \\
\hline C0012C-10H-9, 63 & 86.76 & 0.36 & 1.63 & 2.46 & 0.58 & 1.37 & \\
\hline C0012C-11H-1, 46 & 86.96 & 0.42 & 1.62 & 2.82 & 0.67 & 2.03 & \\
\hline C0012C-10H-9, 107 & 87.20 & 0.39 & 1.58 & 2.45 & 0.61 & 1.56 & \\
\hline C0012C-11H-1, 135 & 87.85 & 0.41 & 1.63 & 2.78 & 0.65 & 1.88 & \\
\hline C0012C-11H-2, 44 & 88.36 & 0.37 & 1.67 & 2.63 & 0.60 & 1.50 & \\
\hline C0012C-11H-2, 117 & 89.09 & 0.41 & 1.60 & 2.61 & 0.63 & 1.74 & \\
\hline C0012C-11H-3, 27 & 89.60 & 0.40 & 1.63 & 2.66 & 0.63 & 1.71 & \\
\hline C0012C-11H-4, 34 & 90.30 & 0.39 & 1.65 & 2.70 & 0.62 & 1.67 & \\
\hline C0012C-11H-4, 105 & 91.01 & 0.40 & 1.62 & 2.64 & 0.63 & 1.70 & \\
\hline C0012C-11H-5, 22 & 91.40 & 0.47 & 1.55 & 2.84 & 0.71 & 2.45 & \\
\hline C0012C-11H-7, 17 & 92.19 & 0.43 & 1.58 & 2.68 & 0.66 & 1.96 & \\
\hline C0012C-11H-7, 55 & 92.57 & 0.37 & 1.68 & 2.66 & 0.60 & 1.50 & \\
\hline C0012C-11H-8, 20 & 92.93 & 0.32 & 1.78 & 2.75 & 0.56 & 1.27 & \\
\hline C0012C-11H-8, 31 & 93.04 & 0.36 & 1.68 & 2.64 & 0.60 & 1.48 & \\
\hline C0012C-11H-8, 121 & 93.94 & 0.38 & 1.61 & 2.48 & 0.60 & 1.47 & \\
\hline $\mathrm{C} 0012 \mathrm{C}-12 \mathrm{H}-1,48$ & 94.48 & 0.35 & 1.69 & 2.59 & 0.57 & 1.34 & \\
\hline C0012C-12H-1, 129 & 95.29 & 0.35 & 1.67 & 2.54 & 0.58 & 1.36 & \\
\hline $\mathrm{C} 0012 \mathrm{C}-12 \mathrm{H}-2,46$ & 95.88 & 0.32 & 1.76 & 2.66 & 0.55 & 1.24 & \\
\hline $\mathrm{C} 0012 \mathrm{C}-12 \mathrm{H}-2,135$ & 96.77 & 0.32 & 1.81 & 2.82 & 0.57 & 1.30 & \\
\hline
\end{tabular}


Table T7 (continued). (Continued on next page.)

\begin{tabular}{|c|c|c|c|c|c|c|c|}
\hline \multirow{2}{*}{$\begin{array}{l}\text { Hole, core, section, } \\
\text { interval }(\mathrm{cm})\end{array}$} & \multirow{2}{*}{$\begin{array}{l}\text { Depth CSF } \\
\quad(\mathrm{m})\end{array}$} & \multirow{2}{*}{$\begin{array}{l}\text { Water content } \\
\quad(w t \%)\end{array}$} & \multicolumn{2}{|c|}{ Density $\left(\mathrm{g} / \mathrm{cm}^{3}\right)$} & \multirow{2}{*}{$\begin{array}{c}\text { Porosity } \\
\text { (fractional) }\end{array}$} & \multirow[b]{2}{*}{ Void ratio } & \multirow[b]{2}{*}{ Lithologic note } \\
\hline & & & Bulk & Grain & & & \\
\hline $\mathrm{C} 0012 \mathrm{C}-12 \mathrm{H}-3,44$ & 97.27 & 0.36 & 1.71 & 2.72 & 0.59 & 1.47 & \\
\hline $\mathrm{C} 0012 \mathrm{C}-12 \mathrm{H}-3,114$ & 97.97 & 0.35 & 1.77 & 2.87 & 0.60 & 1.49 & \\
\hline $\mathrm{C} 0012 \mathrm{C}-12 \mathrm{H}-4,35$ & 98.59 & 0.35 & 1.68 & 2.56 & 0.58 & 1.35 & \\
\hline $\mathrm{C} 0012 \mathrm{C}-12 \mathrm{H}-4,108$ & 99.32 & 0.33 & 1.73 & 2.61 & 0.56 & 1.25 & \\
\hline $\mathrm{C} 0012 \mathrm{C}-12 \mathrm{H}-5,34$ & 99.98 & 0.35 & 1.70 & 2.60 & 0.57 & 1.34 & \\
\hline $\mathrm{C} 0012 \mathrm{C}-12 \mathrm{H}-5,118$ & 100.82 & 0.33 & 1.70 & 2.55 & 0.56 & 1.25 & \\
\hline C0012C-12H-6, 27 & 101.32 & 0.33 & 1.71 & 2.56 & 0.55 & 1.24 & \\
\hline $\mathrm{C} 0012 \mathrm{C}-12 \mathrm{H}-6,83$ & 101.88 & 0.34 & 1.76 & 2.79 & 0.59 & 1.42 & \\
\hline $\mathrm{C} 0012 \mathrm{C}-13 \mathrm{H}-1,28$ & 102.28 & 0.33 & 1.76 & 2.75 & 0.57 & 1.33 & \\
\hline $\mathrm{C} 0012 \mathrm{C}-13 \mathrm{H}-1,60$ & 102.60 & 0.35 & 1.71 & 2.65 & 0.58 & 1.38 & \\
\hline $\mathrm{C} 0012 \mathrm{C}-13 \mathrm{H}-1,118$ & 103.18 & 0.33 & 1.77 & 2.77 & 0.57 & 1.33 & \\
\hline $\mathrm{C} 0012 \mathrm{C}-13 \mathrm{H}-2,125$ & 104.66 & 0.35 & 1.71 & 2.71 & 0.59 & 1.44 & \\
\hline $\mathrm{C} 0012 \mathrm{C}-13 \mathrm{H}-3,41$ & 105.23 & 0.34 & 1.72 & 2.66 & 0.58 & 1.37 & \\
\hline $\mathrm{C} 0012 \mathrm{C}-13 \mathrm{H}-5,47$ & 106.73 & 0.34 & 1.73 & 2.69 & 0.58 & 1.36 & \\
\hline C0012C-13H-5, 120 & 107.46 & 0.35 & 1.72 & 2.72 & 0.59 & 1.41 & \\
\hline C0012C-13H-6, 24 & 107.91 & 0.32 & 1.71 & 2.52 & 0.54 & 1.18 & \\
\hline $\mathrm{C} 0012 \mathrm{C}-14 \mathrm{H}-2,26.5$ & 108.61 & 0.34 & 1.71 & 2.61 & 0.57 & 1.30 & \\
\hline $\mathrm{C} 0012 \mathrm{C}-14 \mathrm{H}-3,69$ & 109.32 & 0.35 & 1.71 & 2.66 & 0.58 & 1.40 & \\
\hline $\mathrm{C} 0012 \mathrm{C}-14 \mathrm{H}-4,19$ & 109.62 & 0.34 & 1.74 & 2.72 & 0.58 & 1.38 & \\
\hline C0012C-14H-4, 111 & 110.54 & 0.35 & 1.70 & 2.66 & 0.58 & 1.41 & \\
\hline C0012C-14H-5, 24 & 111.08 & 0.36 & 1.70 & 2.69 & 0.59 & 1.45 & \\
\hline C0012C-14H-5, 116 & 112.00 & 0.37 & 1.72 & 2.84 & 0.62 & 1.60 & \\
\hline C0012C-14H-6, 23 & 112.48 & 0.34 & 1.73 & 2.69 & 0.58 & 1.36 & \\
\hline $\mathrm{C} 0012 \mathrm{C}-14 \mathrm{H}-6,98$ & 113.23 & 0.35 & 1.70 & 2.63 & 0.58 & 1.37 & \\
\hline $\mathrm{C} 0012 \mathrm{C}-14 \mathrm{H}-7,28$ & 113.94 & 0.35 & 1.68 & 2.58 & 0.58 & 1.37 & \\
\hline C0012C-14H-7, 99 & 114.65 & 0.35 & 1.72 & 2.69 & 0.58 & 1.41 & \\
\hline $\mathrm{C} 0012 \mathrm{C}-14 \mathrm{H}-8,30$ & 115.36 & 0.36 & 1.70 & 2.68 & 0.59 & 1.45 & \\
\hline $\mathrm{C} 0012 \mathrm{C}-14 \mathrm{H}-8,99$ & 116.05 & 0.41 & 1.55 & 2.39 & 0.62 & 1.61 & \\
\hline $\mathrm{C} 0012 \mathrm{C}-15 \mathrm{H}-1,36$ & 116.36 & 0.37 & 1.64 & 2.52 & 0.59 & 1.43 & \\
\hline $\mathrm{C} 0012 \mathrm{C}-15 \mathrm{H}-1,98$ & 116.98 & 0.36 & 1.69 & 2.69 & 0.60 & 1.48 & \\
\hline $\mathrm{C} 0012 \mathrm{C}-15 \mathrm{H}-2,36$ & 117.78 & 0.36 & 1.70 & 2.69 & 0.59 & 1.46 & \\
\hline $\mathrm{C} 0012 \mathrm{C}-15 \mathrm{H}-2,125.5$ & 118.68 & 0.35 & 1.72 & 2.74 & 0.60 & 1.47 & \\
\hline C0012D-2H-1, 114 & 119.14 & 0.38 & 1.68 & 2.74 & 0.62 & 1.62 & \\
\hline $\mathrm{C} 0012 \mathrm{C}-15 \mathrm{H}-3,35$ & 119.19 & 0.34 & 1.72 & 2.67 & 0.58 & 1.37 & \\
\hline $\mathrm{C} 0012 \mathrm{D}-2 \mathrm{H}-2,21$ & 119.62 & 0.36 & 1.70 & 2.69 & 0.60 & 1.47 & \\
\hline C0012C-15H-3, 103 & 119.87 & 0.35 & 1.73 & 2.77 & 0.59 & 1.46 & \\
\hline $\mathrm{C} 0012 \mathrm{D}-2 \mathrm{H}-3,26.5$ & 120.05 & 0.37 & 1.68 & 2.69 & 0.61 & 1.55 & \\
\hline $\mathrm{C} 0012 \mathrm{D}-2 \mathrm{H}-4,45$ & 120.52 & 0.36 & 1.71 & 2.73 & 0.60 & 1.51 & \\
\hline $\mathrm{C} 0012 \mathrm{C}-15 \mathrm{H}-4,29.5$ & 120.55 & 0.37 & 1.66 & 2.63 & 0.60 & 1.52 & \\
\hline $\mathrm{C} 0012 \mathrm{C}-15 \mathrm{H}-5,33$ & 120.90 & 0.36 & 1.74 & 2.82 & 0.60 & 1.52 & \\
\hline C0012D-2H-5, 20 & 121.07 & 0.38 & 1.69 & 2.78 & 0.62 & 1.64 & \\
\hline C0012D-2H-5, 86 & 121.73 & 0.39 & 1.63 & 2.62 & 0.62 & 1.61 & \\
\hline C0012C-15H-5, 126 & 121.83 & 0.35 & 1.71 & 2.70 & 0.59 & 1.45 & \\
\hline C0012D-2H-6, 21 & 122.21 & 0.39 & 1.64 & 2.67 & 0.63 & 1.69 & \\
\hline $\mathrm{C} 0012 \mathrm{C}-15 \mathrm{H}-6,30$ & 122.29 & 0.39 & 1.65 & 2.71 & 0.63 & 1.69 & \\
\hline C0012D-2H-6, 116 & 123.16 & 0.39 & 1.66 & 2.71 & 0.62 & 1.67 & \\
\hline C0012C-15H-7, 28 & 123.31 & 0.38 & 1.64 & 2.61 & 0.61 & 1.56 & \\
\hline C0012D-2H-7, 22 & 123.64 & 0.40 & 1.61 & 2.64 & 0.64 & 1.75 & \\
\hline C0012D-2H-7, 121 & 124.63 & 0.37 & 1.69 & 2.76 & 0.62 & 1.61 & \\
\hline $\mathrm{C} 0012 \mathrm{D}-2 \mathrm{H}-8,23$ & 125.10 & 0.40 & 1.63 & 2.68 & 0.63 & 1.72 & \\
\hline C0012D-2H-8, 104 & 125.91 & 0.38 & 1.66 & 2.72 & 0.62 & 1.65 & \\
\hline C0012D-2H-9, 28 & 126.60 & 0.39 & 1.66 & 2.78 & 0.64 & 1.77 & \\
\hline C0012D-3H-1, 38 & 126.88 & 0.39 & 1.65 & 2.69 & 0.62 & 1.65 & \\
\hline C0012D-3H-1, 129 & 127.79 & 0.34 & 1.72 & 2.67 & 0.58 & 1.37 & \\
\hline $\mathrm{C} 0012 \mathrm{D}-3 \mathrm{H}-2,25$ & 128.17 & 0.37 & 1.71 & 2.78 & 0.61 & 1.57 & \\
\hline C0012D-3H-2, 103 & 128.95 & 0.37 & 1.68 & 2.65 & 0.60 & 1.49 & \\
\hline C0012D-3H-2, 125.5 & 129.18 & 0.37 & 1.67 & 2.66 & 0.61 & 1.55 & \\
\hline $\mathrm{C} 0012 \mathrm{D}-3 \mathrm{H}-3,28.5$ & 129.62 & 0.40 & 1.64 & 2.76 & 0.64 & 1.79 & \\
\hline C0012D-3H-4, 15 & 129.79 & 0.39 & 1.64 & 2.68 & 0.63 & 1.70 & \\
\hline C0012D-3H-4, 114 & 130.78 & 0.39 & 1.70 & 2.94 & 0.65 & 1.82 & \\
\hline C0012D-3H-5, 36 & 131.43 & 0.37 & 1.67 & 2.67 & 0.61 & 1.56 & \\
\hline C0012D-3H-5, 119 & 132.26 & 0.38 & 1.64 & 2.59 & 0.60 & 1.53 & \\
\hline C0012D-3H-6, 46 & 132.95 & 0.40 & 1.61 & 2.59 & 0.63 & 1.67 & \\
\hline C0012D-3H-6, 100 & 133.49 & 0.36 & 1.69 & 2.63 & 0.59 & 1.43 & \\
\hline C0012D-4H-1, 33 & 134.33 & 0.39 & 1.61 & 2.52 & 0.61 & 1.56 & \\
\hline C0012D-4H-1, 120 & 135.20 & 0.38 & 1.61 & 2.50 & 0.60 & 1.52 & \\
\hline C0012D-4H-2, 21 & 135.62 & 0.43 & 1.51 & 2.38 & 0.64 & 1.79 & \\
\hline C0012D-4H-2, 97 & 136.38 & 0.41 & 1.58 & 2.51 & 0.63 & 1.69 & \\
\hline C0012D-4H-2, 125.5 & 136.67 & 0.37 & 1.66 & 2.65 & 0.61 & 1.55 & \\
\hline
\end{tabular}


Table T7 (continued). (Continued on next page.)

\begin{tabular}{|c|c|c|c|c|c|c|c|}
\hline \multirow{2}{*}{$\begin{array}{l}\text { Hole, core, section, } \\
\text { interval }(\mathrm{cm})\end{array}$} & \multirow{2}{*}{$\begin{array}{l}\text { Depth CSF } \\
\text { (m) }\end{array}$} & \multirow{2}{*}{$\begin{array}{l}\text { Water content } \\
\quad(w t \%)\end{array}$} & \multicolumn{2}{|c|}{ Density $\left(\mathrm{g} / \mathrm{cm}^{3}\right)$} & \multirow{2}{*}{$\begin{array}{c}\text { Porosity } \\
\text { (fractional) }\end{array}$} & \multirow[b]{2}{*}{ Void ratio } & \multirow[b]{2}{*}{ Lithologic note } \\
\hline & & & Bulk & Grain & & & \\
\hline C0012D-4H-3, 23 & 137.06 & 0.39 & 1.58 & 2.44 & 0.60 & 1.52 & \\
\hline C0012D-4H-4, 29.5 & 138.24 & 0.35 & 1.72 & 2.75 & 0.60 & 1.47 & \\
\hline C0012D-4H-5, 21 & 138.47 & 0.34 & 1.69 & 2.54 & 0.56 & 1.27 & \\
\hline C0012D-4H-5, 120.5 & 139.46 & 0.34 & 1.71 & 2.60 & 0.56 & 1.30 & \\
\hline C0012D-4H-6, 13 & 139.80 & 0.37 & 1.65 & 2.55 & 0.59 & 1.45 & \\
\hline C0012D-5H-1, 67 & 141.67 & 0.36 & 1.70 & 2.69 & 0.59 & 1.46 & \\
\hline C0012D-5H-1, 134 & 142.34 & 0.35 & 1.70 & 2.63 & 0.58 & 1.39 & \\
\hline $\mathrm{C} 0012 \mathrm{D}-5 \mathrm{H}-2,23$ & 142.64 & 0.38 & 1.65 & 2.62 & 0.61 & 1.55 & \\
\hline C0012D-5H-2, 94 & 143.35 & 0.37 & 1.68 & 2.66 & 0.60 & 1.50 & \\
\hline C0012D-5H-2, 108 & 143.49 & 0.33 & 1.75 & 2.70 & 0.57 & 1.31 & \\
\hline C0012D-5H-3, 15 & 143.98 & 0.33 & 1.74 & 2.66 & 0.56 & 1.29 & \\
\hline C0012D-5H-3, 54 & 144.37 & 0.32 & 1.77 & 2.69 & 0.55 & 1.23 & \\
\hline C0012D-5H-5, 4 & 145.09 & 0.34 & 1.77 & 2.81 & 0.58 & 1.40 & \\
\hline C0012D-5H-5, 30 & 145.35 & 0.32 & 1.78 & 2.70 & 0.55 & 1.21 & \\
\hline C0012D-5H-5, 122 & 146.27 & 0.34 & 1.76 & 2.76 & 0.58 & 1.36 & \\
\hline C0012D-6H-1, 32 & 146.82 & 0.38 & 1.68 & 2.74 & 0.62 & 1.62 & \\
\hline C0012D-6H-1, 115 & 147.65 & 0.36 & 1.70 & 2.71 & 0.60 & 1.49 & \\
\hline C0012D-6H-2, 28 & 148.19 & 0.35 & 1.71 & 2.66 & 0.58 & 1.40 & \\
\hline C0012D-6H-2, 110 & 149.01 & 0.36 & 1.67 & 2.58 & 0.58 & 1.40 & \\
\hline C0012D-6H-3, 21 & 149.54 & 0.34 & 1.71 & 2.63 & 0.57 & 1.33 & \\
\hline C0012D-6H-4, 67 & 150.30 & 0.34 & 1.72 & 2.64 & 0.57 & 1.32 & \\
\hline C0012D-6H-6, 44 & 151.42 & 0.31 & 1.79 & 2.72 & 0.55 & 1.22 & \\
\hline C0012D-7H-1, 73 & 152.73 & 0.34 & 1.74 & 2.73 & 0.58 & 1.37 & \\
\hline C0012D-7H-1, 123 & 153.23 & 0.34 & 1.74 & 2.72 & 0.58 & 1.38 & \\
\hline C0012D-7H-2, 35 & 153.76 & 0.34 & 1.73 & 2.67 & 0.57 & 1.34 & \\
\hline C0012D-7H-2, 110 & 154.51 & 0.31 & 1.78 & 2.65 & 0.54 & 1.17 & \\
\hline C0012D-7H-3, 29 & 155.06 & 0.36 & 1.72 & 2.74 & 0.60 & 1.47 & \\
\hline C0012D-7H-4, 27 & 155.35 & 0.34 & 1.72 & 2.64 & 0.57 & 1.32 & \\
\hline C0012D-7H-4, 125 & 156.33 & 0.31 & 1.76 & 2.60 & 0.53 & 1.14 & \\
\hline C0012D-7H-5, 6 & 156.55 & 0.35 & 1.73 & 2.73 & 0.58 & 1.41 & \\
\hline C0012D-7H-5, 20 & 156.69 & 0.32 & 1.79 & 2.74 & 0.56 & 1.26 & \\
\hline C0012D-8H-1, 39 & 157.89 & 0.33 & 1.77 & 2.79 & 0.58 & 1.36 & \\
\hline C0012D-8H-1, 109 & 158.59 & 0.34 & 1.74 & 2.76 & 0.59 & 1.41 & \\
\hline C0012D-8H-2, 58 & 159.49 & 0.31 & 1.81 & 2.76 & 0.55 & 1.22 & \\
\hline C0012D-8H-3, 14 & 159.80 & 0.31 & 1.79 & 2.70 & 0.55 & 1.20 & \\
\hline C0012D-8H-3, 56.5 & 160.23 & 0.30 & 1.80 & 2.65 & 0.53 & 1.11 & \\
\hline C0012D-8H-4, 29.5 & 160.68 & 0.30 & 1.79 & 2.62 & 0.52 & 1.09 & \\
\hline C0012D-8H-5, 10 & 160.80 & 0.34 & 1.74 & 2.72 & 0.58 & 1.36 & \\
\hline C0012D-8H-6, 12 & 162.23 & 0.26 & 1.88 & 2.64 & 0.47 & 0.90 & Sand/Ash \\
\hline C0012D-9H-1, 24 & 162.74 & 0.32 & 1.77 & 2.68 & 0.55 & 1.21 & \\
\hline C0012D-9H-1, 116 & 163.66 & 0.34 & 1.74 & 2.75 & 0.59 & 1.42 & \\
\hline C0012D-9H-2, 49 & 164.40 & 0.31 & 1.80 & 2.74 & 0.55 & 1.21 & \\
\hline C0012D-9H-2, 98 & 164.89 & 0.27 & 1.89 & 2.73 & 0.49 & 0.96 & \\
\hline C0012D-9H-3, 27 & 165.59 & 0.29 & 1.86 & 2.79 & 0.53 & 1.13 & \\
\hline C0012D-9H-3, 119.5 & 166.51 & 0.27 & 1.84 & 2.62 & 0.49 & 0.95 & \\
\hline C0012D-9H-4, 37 & 167.09 & 0.30 & 1.81 & 2.72 & 0.54 & 1.16 & \\
\hline C0012D-10H-1, 28 & 167.28 & 0.30 & 1.82 & 2.72 & 0.53 & 1.13 & \\
\hline C0012D-10H-1, 118 & 168.18 & 0.29 & 1.84 & 2.74 & 0.52 & 1.10 & \\
\hline C0012D-10H-2, 8 & 168.50 & 0.27 & 1.87 & 2.72 & 0.50 & 1.00 & \\
\hline C0012D-10H-2, 52 & 168.94 & 0.30 & 1.87 & 2.90 & 0.55 & 1.22 & \\
\hline C0012D-10H-2, 88.5 & 169.30 & 0.29 & 1.85 & 2.79 & 0.53 & 1.13 & \\
\hline C0012D-10H-3, 31 & 169.82 & 0.30 & 1.74 & 2.48 & 0.51 & 1.03 & \\
\hline C0012D-10H-4, 80 & 170.64 & 0.29 & 1.82 & 2.69 & 0.52 & 1.08 & \\
\hline C0012D-11H-1, 65 & 171.15 & 0.29 & 1.81 & 2.67 & 0.52 & 1.09 & \\
\hline C0012D-11H-2, 30 & 172.19 & 0.31 & 1.77 & 2.61 & 0.53 & 1.13 & \\
\hline $\mathrm{C} 0012 \mathrm{D}-11 \mathrm{H}-3,7$ & 172.28 & 0.31 & 1.77 & 2.65 & 0.54 & 1.17 & \\
\hline C0012D-11H-3, 73 & 172.94 & 0.30 & 1.82 & 2.73 & 0.53 & 1.14 & \\
\hline C0012D-11H-4, 8 & 173.08 & 0.29 & 1.84 & 2.77 & 0.53 & 1.13 & \\
\hline $\mathrm{C} 0012 \mathrm{D}-11 \mathrm{H}-4,70$ & 173.70 & 0.33 & 1.76 & 2.70 & 0.56 & 1.29 & \\
\hline $\mathrm{C} 0012 \mathrm{D}-12 \mathrm{H}-1,72$ & 174.22 & 0.30 & 1.85 & 2.84 & 0.54 & 1.19 & \\
\hline C0012D-12H-2, 20 & 174.61 & 0.23 & 1.99 & 2.76 & 0.45 & 0.80 & \\
\hline $\mathrm{C} 0012 \mathrm{D}-12 \mathrm{H}-3,8$ & 174.80 & 0.26 & 1.91 & 2.73 & 0.48 & 0.91 & \\
\hline C0012D-12H-3, 27 & 174.99 & 0.28 & 1.87 & 2.74 & 0.51 & 1.03 & \\
\hline C0012D-12H-3, 103 & 175.75 & 0.28 & 1.86 & 2.72 & 0.50 & 1.02 & \\
\hline C0012D-12H-4, 6 & 175.88 & 0.27 & 1.88 & 2.70 & 0.49 & 0.96 & \\
\hline C0012D-12H-5, 16 & 176.18 & 0.27 & 1.83 & 2.57 & 0.48 & 0.92 & \\
\hline C0012D-13H-1, 28 & 176.28 & 0.32 & 1.77 & 2.65 & 0.54 & 1.19 & \\
\hline C0012D-13H-1, 103 & 177.03 & 0.30 & 1.78 & 2.62 & 0.52 & 1.09 & \\
\hline C0012D-13H-1, 124.5 & 177.25 & 0.32 & 1.79 & 2.73 & 0.55 & 1.24 & \\
\hline
\end{tabular}


Table T7 (continued).

\begin{tabular}{|c|c|c|c|c|c|c|c|}
\hline \multirow{2}{*}{$\begin{array}{l}\text { Hole, core, section, } \\
\text { interval }(\mathrm{cm})\end{array}$} & \multirow{2}{*}{$\begin{array}{l}\text { Depth CSF } \\
\text { (m) }\end{array}$} & \multirow{2}{*}{$\begin{array}{l}\text { Water content } \\
\quad(\text { wt } \%)\end{array}$} & \multicolumn{2}{|c|}{ Density $\left(\mathrm{g} / \mathrm{cm}^{3}\right)$} & \multirow{2}{*}{$\begin{array}{l}\text { Porosity } \\
\text { (fractional) }\end{array}$} & \multirow[b]{2}{*}{ Void ratio } & \multirow[b]{2}{*}{ Lithologic note } \\
\hline & & & Bulk & Grain & & & \\
\hline C0012D-13H-2, 32 & 177.73 & 0.30 & 1.79 & 2.62 & 0.52 & 1.10 & \\
\hline C0012D-13H-2, 107 & 178.48 & 0.33 & 1.73 & 2.62 & 0.56 & 1.25 & \\
\hline C0012D-13H-3, 19 & 179.01 & 0.29 & 1.87 & 2.81 & 0.52 & 1.10 & Sand/Ash \\
\hline C0012D-13H-3, 96 & 179.78 & 0.30 & 1.84 & 2.82 & 0.55 & 1.21 & \\
\hline C0012D-13H-4, 31 & 180.22 & 0.36 & 1.67 & 2.63 & 0.60 & 1.47 & \\
\hline C0012E-1X-1, 24 & 500.24 & 0.20 & 2.03 & 2.71 & 0.40 & 0.68 & \\
\hline $\mathrm{C} 0012 \mathrm{E}-1 \mathrm{X}-1,84$ & 500.84 & 0.18 & 2.14 & 2.81 & 0.37 & 0.59 & \\
\hline C0012E-1X-2, 52 & 501.92 & 0.18 & 2.09 & 2.71 & 0.37 & 0.58 & \\
\hline C0012E-1X-3, 61 & 503.07 & 0.24 & 1.93 & 2.69 & 0.46 & 0.85 & \\
\hline C0012E-1X-4, 46 & 503.55 & 0.20 & 2.01 & 2.64 & 0.39 & 0.63 & \\
\hline C0012E-2X-CC, 11 & 510.18 & 0.17 & 2.15 & 2.80 & 0.37 & 0.58 & \\
\hline C0012E-3X-1, 92 & 519.92 & 0.14 & 2.22 & 2.76 & 0.31 & 0.46 & Red claystone \\
\hline C0012E-3X-1, 113.5 & 520.14 & 0.16 & 2.14 & 2.68 & 0.33 & 0.48 & Red claystone \\
\hline C0012E-3X-2, 61 & 521.02 & 0.14 & 2.21 & 2.73 & 0.30 & 0.43 & Red claystone \\
\hline C0012E-3X-3, 36 & 521.40 & 0.13 & 2.28 & 2.76 & 0.28 & 0.39 & Red claystone \\
\hline C0012E-3X-4, 8.5 & 521.93 & 0.18 & 2.12 & 2.75 & 0.37 & 0.58 & Red claystone \\
\hline C0012E-3X-4, 139.5 & 523.24 & 0.19 & 2.06 & 2.69 & 0.38 & 0.62 & Red claystone \\
\hline C0012E-3X-5, 48 & 523.73 & 0.13 & 2.27 & 2.80 & 0.30 & 0.42 & Red claystone \\
\hline C0012E-3X-6, 59.5 & 524.66 & 0.16 & 2.19 & 2.79 & 0.34 & 0.52 & Red claystone \\
\hline C0012E-3X-7, 81 & 525.49 & 0.13 & 2.23 & 2.71 & 0.28 & 0.39 & Red claystone \\
\hline C0012E-3X-8, 66 & 526.76 & 0.10 & 2.44 & 2.87 & 0.23 & 0.30 & Basalt \\
\hline C0012F-2R-1, 64 & 523.14 & 0.09 & 2.51 & 2.93 & 0.22 & 0.29 & Basalt \\
\hline C0012G-1R-1, 73 & 515.73 & 0.20 & 2.02 & 2.67 & 0.39 & 0.65 & Red claystone \\
\hline C0012G-1R-2, 4 & 516.05 & 0.16 & 2.15 & 2.72 & 0.34 & 0.51 & Red claystone \\
\hline C0012G-1R-3, 49 & 517.08 & 0.20 & 2.05 & 2.74 & 0.40 & 0.68 & Red claystone \\
\hline C0012G-1R-4, 51 & 517.61 & 0.14 & 2.20 & 2.73 & 0.31 & 0.44 & Red claystone \\
\hline C0012G-1R-4, 101.5 & 518.12 & 0.16 & 2.16 & 2.74 & 0.34 & 0.51 & Red claystone \\
\hline C0012G-2R-1, 27 & 524.77 & 0.17 & 2.15 & 2.79 & 0.37 & 0.58 & Basalt \\
\hline C0012G-2R-2, 134 & 526.23 & 0.08 & 2.53 & 2.90 & 0.20 & 0.25 & Basalt \\
\hline C0012G-4R-1, 29.5 & 543.80 & 0.15 & 2.28 & 2.93 & 0.34 & 0.52 & Basalt \\
\hline C0012G-5R-1, 4 & 553.04 & 0.11 & 2.40 & 2.89 & 0.26 & 0.36 & Basalt \\
\hline C0012G-6R-CC, 7 & 563.31 & 0.09 & 2.46 & 2.86 & 0.22 & 0.28 & Basalt \\
\hline C0012G-7R-1, 29 & 572.29 & 0.06 & 2.55 & 2.82 & 0.15 & 0.17 & Basalt \\
\hline C0012G-8R-1, 34 & 581.84 & 0.04 & 2.57 & 2.75 & 0.11 & 0.12 & Basalt \\
\hline C0012G-9R-1, 8 & 591.08 & 0.04 & 2.64 & 2.80 & 0.09 & 0.10 & Basalt \\
\hline C0012G-10R-2, 118 & 597.47 & 0.06 & 2.53 & 2.79 & 0.15 & 0.17 & Basalt \\
\hline C0012G-12R-2, 91 & 612.92 & 0.07 & 2.58 & 2.92 & 0.18 & 0.22 & Basalt \\
\hline C0012G-13R-1, 121 & 616.71 & 0.07 & 2.49 & 2.77 & 0.16 & 0.19 & Basalt \\
\hline C0012G-14R-1, 22 & 620.72 & 0.11 & 2.39 & 2.85 & 0.25 & 0.34 & Basalt \\
\hline C0012G-15R-1, 29 & 625.79 & 0.07 & 2.49 & 2.77 & 0.16 & 0.20 & Basalt \\
\hline
\end{tabular}


Table T8. $P$-wave velocity values on discrete samples, Site C0012.

\begin{tabular}{|c|c|c|c|c|c|c|}
\hline \multirow{2}{*}{$\begin{array}{l}\text { Core, section } \\
\text { interval }(\mathrm{cm})\end{array}$} & \multirow{2}{*}{$\begin{array}{c}\text { Depth CSF } \\
\text { (m) }\end{array}$} & \multicolumn{3}{|c|}{ Velocity $(\mathrm{m} / \mathrm{s})$} & \multirow[b]{2}{*}{$\alpha_{\mathrm{VPhor}}(\%)$} & \multirow[b]{2}{*}{$\alpha_{\text {VPvert }}(\%)$} \\
\hline & & $x$-direction & $y$-direction & $z$-direction & & \\
\hline \multicolumn{7}{|l|}{ 333-C0012E- } \\
\hline $1 X-1,84-86$ & 500.85 & 2193 & 2142 & 1969 & 2.32 & 9.61 \\
\hline $3 X-1,93-95$ & 519.94 & 2371 & 2412 & 2309 & -1.71 & 3.51 \\
\hline $3 X-4,93-95$ & 522.78 & 2495 & 2494 & 2191 & 0.04 & 12.94 \\
\hline $3 X-8,66-68$ & 526.76 & 3846 & 3824 & 3689 & 0.56 & 3.89 \\
\hline \multicolumn{7}{|l|}{ 333-C0012F- } \\
\hline $2 R-1,64-66$ & 522.15 & 3823 & 3808 & 3768 & 0.39 & 1.25 \\
\hline \multicolumn{7}{|l|}{ 333-C0012G- } \\
\hline $1 \mathrm{R}-2,5-7$ & 516.07 & 2176 & 2171 & 2032 & 0.21 & 6.75 \\
\hline $1 R-4,51-53$ & 517.62 & 2317 & 2282 & 2129 & 1.51 & 7.68 \\
\hline $2 \mathrm{R}-1,27-29$ & 524.78 & 2223 & 2271 & 2085 & -2.17 & 7.48 \\
\hline $2 \mathrm{R}-2,134-136$ & 526.24 & 4225 & 4207 & 4192 & 0.43 & 0.57 \\
\hline $4 \mathrm{R}-1,29-31$ & 543.80 & 3165 & 3174 & 3160 & -0.29 & 0.28 \\
\hline $5 R-1,4-6$ & 553.05 & 3231 & 3191 & 3218 & 1.26 & -0.22 \\
\hline 6R-CC, 7-9 & 563.32 & 4118 & 3918 & 4060 & 4.97 & -1.04 \\
\hline 7R-1, 29-31 & 572.30 & 4337 & 4259 & 4203 & 1.81 & 2.23 \\
\hline $8 R-1,34-36$ & 581.85 & 5172 & 5111 & 5145 & 1.19 & -0.07 \\
\hline $9 R-1,8-10$ & 591.09 & 3636 & 3772 & 3734 & -3.68 & -0.81 \\
\hline $10 \mathrm{R}-2,118-120$ & 597.48 & 4644 & 4431 & 4410 & 4.69 & 2.84 \\
\hline $12 \mathrm{R}-2,91-93$ & 612.93 & 4196 & 4116 & 4072 & 1.93 & 2.05 \\
\hline $13 R-1,121-123$ & 616.72 & 4543 & 4609 & 4601 & -1.43 & -0.53 \\
\hline $14 \mathrm{R}-1,22-24$ & 620.73 & 4875 & 4810 & 4951 & 1.34 & -2.23 \\
\hline 15R-1, 29-31 & 625.80 & 4645 & 4689 & 4517 & -0.94 & 3.25 \\
\hline
\end{tabular}


Table T9. Electrical resistivity values determined from impedance, Site C0012. (Continued on next page.)

\begin{tabular}{|c|c|c|}
\hline $\begin{array}{l}\text { Core, section } \\
\text { interval }(\mathrm{cm})\end{array}$ & $\begin{array}{l}\text { Depth CSF } \\
(\mathrm{m})\end{array}$ & $\begin{array}{c}\text { Resistivity } \\
(\Omega \mathrm{m})\end{array}$ \\
\hline \multicolumn{3}{|l|}{ 333-C0012C- } \\
\hline $1 \mathrm{H}-1,124$ & 1.24 & 0.489 \\
\hline $1 \mathrm{H}-2,20$ & 1.61 & 0.826 \\
\hline $1 \mathrm{H}-3,41$ & 3.21 & 0.460 \\
\hline $1 \mathrm{H}-3,103$ & 3.83 & 0.421 \\
\hline $1 \mathrm{H}-4,10$ & 4.32 & 0.477 \\
\hline $2 \mathrm{H}-1,28$ & 4.78 & 0.454 \\
\hline $2 \mathrm{H}-2,27$ & 6.19 & 0.462 \\
\hline $2 \mathrm{H}-3,25$ & 7.57 & 0.544 \\
\hline $2 \mathrm{H}-4,26$ & 8.99 & 0.626 \\
\hline $2 \mathrm{H}-5,25$ & 10.39 & 0.721 \\
\hline $2 \mathrm{H}-6,24$ & 11.81 & 0.734 \\
\hline $2 \mathrm{H}-6,88$ & 12.45 & 0.840 \\
\hline $2 \mathrm{H}-7,25$ & 13.22 & 0.478 \\
\hline $2 \mathrm{H}-7,93$ & 13.90 & 0.515 \\
\hline $3 \mathrm{H}-1,22$ & 14.22 & 0.405 \\
\hline $3 \mathrm{H}-1,86$ & 14.86 & 0.429 \\
\hline $3 \mathrm{H}-2,25$ & 15.66 & 0.597 \\
\hline $3 \mathrm{H}-2,93$ & 16.34 & 0.506 \\
\hline $3 \mathrm{H}-3,32$ & 17.13 & 0.429 \\
\hline $3 \mathrm{H}-3,90$ & 17.71 & 0.435 \\
\hline $3 \mathrm{H}-4,32$ & 18.56 & 0.479 \\
\hline $3 \mathrm{H}-5,10$ & 19.76 & 0.459 \\
\hline $3 \mathrm{H}-5,71$ & 20.37 & 0.511 \\
\hline $3 \mathrm{H}-6,31$ & 21.39 & 0.664 \\
\hline $3 \mathrm{H}-7,32$ & 22.80 & 0.494 \\
\hline $3 \mathrm{H}-7,101$ & 23.49 & 0.496 \\
\hline $4 \mathrm{H}-1,26$ & 23.76 & 0.474 \\
\hline $4 \mathrm{H}-1,97$ & 24.47 & 0.725 \\
\hline $4 \mathrm{H}-2,28$ & 25.20 & 0.693 \\
\hline $4 \mathrm{H}-2,115$ & 26.07 & 0.472 \\
\hline $4 \mathrm{H}-3,5$ & 26.38 & 0.503 \\
\hline $4 \mathrm{H}-3,66$ & 26.99 & 0.589 \\
\hline $4 \mathrm{H}-5,20$ & 28.18 & 0.475 \\
\hline $4 \mathrm{H}-6,28$ & 29.47 & 0.553 \\
\hline $4 \mathrm{H}-6,89$ & 30.08 & 0.541 \\
\hline $4 \mathrm{H}-7,12$ & 30.73 & 0.630 \\
\hline $4 \mathrm{H}-8,10$ & 32.13 & 1.026 \\
\hline $5 \mathrm{H}-1,42.5$ & 33.43 & 0.459 \\
\hline $5 \mathrm{H}-1,129$ & 34.29 & 0.424 \\
\hline $5 \mathrm{H}-2,25$ & 34.65 & 0.418 \\
\hline $5 \mathrm{H}-2,87$ & 35.27 & 0.500 \\
\hline $5 \mathrm{H}-4,15$ & 36.20 & 0.430 \\
\hline $5 \mathrm{H}-4,127.5$ & 37.32 & 0.473 \\
\hline $5 \mathrm{H}-5,41$ & 37.92 & 0.443 \\
\hline $5 \mathrm{H}-5,112$ & 38.63 & 0.447 \\
\hline $5 \mathrm{H}-6,35$ & 39.27 & 0.436 \\
\hline $5 \mathrm{H}-6,115.5$ & 40.07 & 0.439 \\
\hline $5 \mathrm{H}-7,30.5$ & 40.63 & 0.427 \\
\hline $5 \mathrm{H}-7,97.5$ & 41.30 & 0.447 \\
\hline $5 \mathrm{H}-8,39.5$ & 42.13 & 0.453 \\
\hline $6 \mathrm{H}-1,41.5$ & 42.92 & 0.456 \\
\hline $6 \mathrm{H}-1,106$ & 43.56 & 0.471 \\
\hline $6 \mathrm{H}-2,18.5$ & 44.10 & 0.476 \\
\hline $6 \mathrm{H}-2,139$ & 45.31 & 0.449 \\
\hline $6 \mathrm{H}-3,15$ & 45.49 & 0.495 \\
\hline $6 \mathrm{H}-3,115.5$ & 46.49 & 0.491 \\
\hline $6 \mathrm{H}-5,25.5$ & 47.24 & 0.481 \\
\hline $6 \mathrm{H}-5,118$ & 48.17 & 0.483 \\
\hline $6 \mathrm{H}-6,14.5$ & 48.55 & 0.529 \\
\hline $6 \mathrm{H}-6,103$ & 49.44 & 0.499 \\
\hline $6 \mathrm{H}-7,18$ & 50.01 & 0.441 \\
\hline $6 \mathrm{H}-7,116$ & 50.99 & 0.480 \\
\hline $6 \mathrm{H}-8,15$ & 51.39 & 0.518 \\
\hline $6 \mathrm{H}-8,106$ & 52.30 & 0.499 \\
\hline $8 \mathrm{H}-1,90$ & 60.90 & 0.454 \\
\hline $8 \mathrm{H}-2,33$ & 61.74 & 0.656 \\
\hline $8 \mathrm{H}-3,46$ & 63.30 & 0.732 \\
\hline $8 \mathrm{H}-5,22$ & 64.70 & 0.545 \\
\hline
\end{tabular}

\begin{tabular}{|c|c|c|}
\hline $\begin{array}{l}\text { Core, section } \\
\text { interval }(\mathrm{cm})\end{array}$ & $\begin{array}{l}\text { Depth CSF } \\
\text { (m) }\end{array}$ & $\begin{array}{l}\text { Resistivity } \\
\quad(\Omega \mathrm{m})\end{array}$ \\
\hline $8 \mathrm{H}-6,16$ & 66.04 & 0.538 \\
\hline $8 \mathrm{H}-7,18$ & 67.47 & 0.477 \\
\hline $8 \mathrm{H}-8,20$ & 68.90 & 1.173 \\
\hline $9 \mathrm{H}-1,120$ & 70.70 & 0.646 \\
\hline $9 \mathrm{H}-2,24$ & 71.19 & 0.535 \\
\hline $9 \mathrm{H}-3,23$ & 72.60 & 0.501 \\
\hline $9 \mathrm{H}-3,102$ & 73.39 & 0.619 \\
\hline $9 \mathrm{H}-5,22$ & 74.25 & 0.486 \\
\hline $9 \mathrm{H}-5,104$ & 75.07 & 0.684 \\
\hline $9 \mathrm{H}-6,19$ & 75.65 & 0.577 \\
\hline $9 \mathrm{H}-6,111$ & 76.57 & 0.770 \\
\hline $9 \mathrm{H}-7,104$ & 77.94 & 1.028 \\
\hline $9 \mathrm{H}-8,32$ & 78.63 & 0.835 \\
\hline $10 \mathrm{H}-1,20$ & 79.20 & 0.651 \\
\hline $10 \mathrm{H}-2,102$ & 81.44 & 0.832 \\
\hline $10 \mathrm{H}-3,15$ & 81.98 & 0.845 \\
\hline $10 \mathrm{H}-4,10$ & 82.18 & 0.699 \\
\hline $10 \mathrm{H}-5,78$ & 83.09 & 0.761 \\
\hline $10 \mathrm{H}-6,33$ & 83.61 & 1.108 \\
\hline $10 \mathrm{H}-6,101$ & 84.29 & 0.744 \\
\hline $10 \mathrm{H}-8,25$ & 85.16 & 0.778 \\
\hline $10 \mathrm{H}-8,103$ & 85.94 & 0.901 \\
\hline $10 \mathrm{H}-9,32$ & 86.45 & 0.803 \\
\hline $11 \mathrm{H}-1,42$ & 86.92 & 0.763 \\
\hline $11 \mathrm{H}-1,132$ & 87.82 & 0.779 \\
\hline $11 \mathrm{H}-2,43$ & 88.35 & 0.844 \\
\hline $11 \mathrm{H}-2,121.5$ & 89.14 & 0.797 \\
\hline $11 \mathrm{H}-3,30.5$ & 89.63 & 0.822 \\
\hline $11 \mathrm{H}-4,37$ & 90.33 & 0.857 \\
\hline $11 \mathrm{H}-5,21.5$ & 91.39 & 0.825 \\
\hline $11 \mathrm{H}-5,41$ & 91.59 & 0.833 \\
\hline $11 \mathrm{H}-7,22$ & 92.24 & 0.825 \\
\hline $11 \mathrm{H}-8,30$ & 93.03 & 0.963 \\
\hline $11 \mathrm{H}-8,126$ & 93.99 & 0.948 \\
\hline $12 \mathrm{H}-1,47.5$ & 94.48 & 0.911 \\
\hline $12 \mathrm{H}-1,128.5$ & 95.29 & 1.025 \\
\hline $12 \mathrm{H}-2,45.5$ & 95.88 & 1.445 \\
\hline $12 \mathrm{H}-2,134$ & 96.76 & 1.062 \\
\hline $12 \mathrm{H}-3,49$ & 97.32 & 0.945 \\
\hline $12 \mathrm{H}-3,114$ & 97.97 & 0.979 \\
\hline $12 \mathrm{H}-4,34$ & 98.58 & 0.984 \\
\hline $12 \mathrm{H}-4,116$ & 99.40 & 1.041 \\
\hline $12 \mathrm{H}-5,39$ & 100.03 & 0.977 \\
\hline $12 \mathrm{H}-5,123$ & 100.87 & 0.979 \\
\hline $12 \mathrm{H}-6,85$ & 101.90 & 0.972 \\
\hline $12 \mathrm{H}-6,110$ & 102.15 & 1.006 \\
\hline $13 \mathrm{H}-1,106$ & 103.06 & 1.036 \\
\hline $13 \mathrm{H}-2,10$ & 103.51 & 1.136 \\
\hline $13 \mathrm{H}-3,29$ & 105.11 & 1.398 \\
\hline $13 \mathrm{H}-5,40$ & 106.66 & 1.063 \\
\hline $13 \mathrm{H}-6,27$ & 107.94 & 1.064 \\
\hline $14 \mathrm{H}-1,18$ & 108.18 & 0.863 \\
\hline $14 \mathrm{H}-1,31$ & 108.31 & 0.957 \\
\hline $14 \mathrm{H}-2,17$ & 108.51 & 1.084 \\
\hline $14 \mathrm{H}-5,28$ & 111.12 & 1.021 \\
\hline $14 \mathrm{H}-5,117$ & 112.01 & 1.107 \\
\hline $14 \mathrm{H}-6,24$ & 112.49 & 1.234 \\
\hline $14 \mathrm{H}-6,101$ & 113.26 & 0.949 \\
\hline $14 \mathrm{H}-7,31$ & 113.97 & 1.064 \\
\hline $14 \mathrm{H}-7,103$ & 114.69 & 0.967 \\
\hline $14 \mathrm{H}-8,32$ & 115.38 & 1.047 \\
\hline $14 \mathrm{H}-8,103$ & 116.09 & 1.043 \\
\hline $15 \mathrm{H}-1,34$ & 116.34 & 0.922 \\
\hline $15 \mathrm{H}-2,22$ & 117.64 & 1.017 \\
\hline $15 \mathrm{H}-3,32$ & 119.16 & 1.082 \\
\hline $15 \mathrm{H}-5,8$ & 120.65 & 0.893 \\
\hline $15 \mathrm{H}-6,28$ & 122.27 & 1.008 \\
\hline $15 \mathrm{H}-7,24$ & 123.27 & 0.902 \\
\hline
\end{tabular}


Table T9 (continued).

\begin{tabular}{lcc}
\hline $\begin{array}{l}\text { Core, section } \\
\text { interval (cm) }\end{array}$ & $\begin{array}{c}\text { Depth CSF } \\
(\mathrm{m})\end{array}$ & $\begin{array}{c}\text { Resistivity } \\
(\Omega \mathrm{m})\end{array}$ \\
\hline $333-\mathrm{C} 0012 \mathrm{D}-$ & & \\
$2 \mathrm{H}-1,59$ & 118.59 & 0.878 \\
$2 \mathrm{H}-2,18$ & 119.59 & 0.960 \\
$2 \mathrm{H}-4,19$ & 120.26 & 0.942 \\
$2 \mathrm{H}-5,24$ & 121.11 & 0.933 \\
$2 \mathrm{H}-5,85$ & 121.72 & 0.945 \\
$2 \mathrm{H}-6,20$ & 122.20 & 0.939 \\
$2 \mathrm{H}-6,115$ & 123.15 & 0.906 \\
$2 \mathrm{H}-7,22$ & 123.64 & 1.012 \\
$2 \mathrm{H}-7,120$ & 124.62 & 0.896 \\
$2 \mathrm{H}-8,28$ & 125.15 & 0.790 \\
$2 \mathrm{H}-8,104$ & 125.91 & 1.041 \\
$2 \mathrm{H}-9,27$ & 126.59 & 1.059 \\
$3 \mathrm{H}-1,37.5$ & 126.88 & 0.816 \\
$3 \mathrm{H}-1,128$ & 127.78 & 0.978 \\
$3 \mathrm{H}-2,25$ & 128.17 & 0.931 \\
$3 \mathrm{H}-2,101$ & 128.93 & 0.913 \\
$3 \mathrm{H}-4,18$ & 129.82 & 0.834 \\
$3 \mathrm{H}-4,115$ & 130.79 & 0.992 \\
$3 \mathrm{H}-5,35$ & 131.42 & 0.879 \\
$3 \mathrm{H}-5,122$ & 132.29 & 0.890 \\
$3 \mathrm{H}-6,53$ & 133.02 & 1.032 \\
$4 \mathrm{H}-1,39$ & 134.39 & 0.858 \\
$4 \mathrm{H}-1,122$ & 135.22 & 0.850 \\
$4 \mathrm{H}-2,26$ & 135.67 & 0.916 \\
$4 \mathrm{H}-2,102$ & 136.43 & 0.932 \\
$4 \mathrm{H}-3,26$ & 137.09 & 0.824 \\
$4 \mathrm{H}-3,103.5$ & 137.86 & 1.057 \\
$4 \mathrm{H}-5,20$ & 138.46 & 0.978 \\
$4 \mathrm{H}-5,98.5$ & 139.24 & 0.979 \\
$4 \mathrm{H}-6,16$ & 139.83 & 0.922 \\
$4 \mathrm{H}-6,99$ & 140.66 & 1.164 \\
$5 \mathrm{H}-1,65$ & 141.65 & 0.975 \\
$5 \mathrm{H}-1,133$ & 142.33 & 0.992 \\
$5 \mathrm{H}-2,22$ & 142.63 & 1.037 \\
$5 \mathrm{H}-2,93$ & 143.34 & 1.076 \\
$5 \mathrm{H}-3,53$ & 144.36 & 1.203 \\
$5 \mathrm{H}-5,3$ & 145.08 & 1.486 \\
$5 \mathrm{H}-5,128$ & 146.33 & 1.139 \\
$6 \mathrm{H}-1,31$ & 146.81 & 0.929 \\
$6 \mathrm{H}-1,111$ & 147.61 & 1.380 \\
$6 \mathrm{H}-2,28$ & 148.19 & 1.052 \\
$6 \mathrm{H}-2,110$ & 149.01 & 1.214 \\
$6 \mathrm{H}-3,19$ & 149.52 & 1.008 \\
& 150.25 & 1.474 \\
& 151.36 & 1.077 \\
\hline
\end{tabular}

\begin{tabular}{lcc}
\hline $\begin{array}{l}\text { Core, section } \\
\text { interval }(\mathrm{cm})\end{array}$ & $\begin{array}{c}\text { Depth CSF } \\
(\mathrm{m})\end{array}$ & $\begin{array}{c}\text { Resistivity } \\
(\Omega \mathrm{m})\end{array}$ \\
\hline $6 \mathrm{H}-6,104$ & 152.02 & 1.268 \\
$6 \mathrm{H}-7,17$ & 152.56 & 1.618 \\
$7 \mathrm{H}-1,71$ & 152.71 & 0.995 \\
$7 \mathrm{H}-1,124$ & 153.24 & 1.316 \\
$7 \mathrm{H}-2,40$ & 153.81 & 1.000 \\
$7 \mathrm{H}-2,107$ & 154.48 & 1.242 \\
$7 \mathrm{H}-4,31$ & 155.39 & 1.009 \\
$7 \mathrm{H}-4,123$ & 156.31 & 1.204 \\
$7 \mathrm{H}-5,24$ & 156.73 & 1.174 \\
$8 \mathrm{H}-1,32$ & 157.82 & 1.113 \\
$8 \mathrm{H}-1,107$ & 158.57 & 1.126 \\
$8 \mathrm{H}-2,55$ & 159.46 & 1.162 \\
$8 \mathrm{H}-3,15$ & 159.81 & 1.174 \\
$8 \mathrm{H}-5,12$ & 160.82 & 1.049 \\
$8 \mathrm{H}-5,106$ & 161.76 & 1.301 \\
$8 \mathrm{H}-6,14$ & 162.25 & 1.439 \\
$9 \mathrm{H}-1,21$ & 162.71 & 1.127 \\
$9 \mathrm{H}-1,115$ & 163.65 & 1.126 \\
$9 \mathrm{H}-2,34$ & 164.25 & 0.925 \\
$9 \mathrm{H}-2,109$ & 165.00 & 1.804 \\
$9 \mathrm{H}-3,13$ & 165.45 & 1.090 \\
$9 \mathrm{H}-3,85$ & 166.17 & 1.248 \\
$9 \mathrm{H}-4,32$ & 167.04 & 1.395 \\
$10 \mathrm{H}-1,33.5$ & 167.34 & 1.173 \\
$10 \mathrm{H}-1,120$ & 168.20 & 1.277 \\
$10 \mathrm{H}-2,53$ & 168.95 & 1.254 \\
$10 \mathrm{H}-4,14$ & 169.98 & 1.217 \\
$10 \mathrm{H}-4,83$ & 170.67 & 1.266 \\
$11 \mathrm{H}-1,66.5$ & 171.17 & 1.160 \\
$11 \mathrm{H}-1,123$ & 171.73 & 1.578 \\
$11 \mathrm{H}-3,9$ & 172.30 & 1.194 \\
$11 \mathrm{H}-3,74$ & 172.95 & 1.192 \\
$11 \mathrm{H}-4,10.5$ & 173.10 & 1.260 \\
$11 \mathrm{H}-4,71.5$ & 173.71 & 1.176 \\
$12 \mathrm{H}-2,22$ & 174.63 & 1.447 \\
$12 \mathrm{H}-3,9$ & 174.81 & 1.310 \\
$12 \mathrm{H}-3,104$ & 175.76 & 1.874 \\
$12 \mathrm{H}-4,7$ & 175.89 & 1.470 \\
$12 \mathrm{H}-5,17$ & 176.19 & 1.404 \\
$12 \mathrm{H}-5,79$ & 176.81 & 1.171 \\
$13 \mathrm{H}-1,29$ & 176.29 & 1.060 \\
$13 \mathrm{H}-1,103.5$ & 177.04 & 1.034 \\
$13 \mathrm{H}-2,33$ & 177.74 & 1.172 \\
& 179.79 & 1.074 \\
$13 \mathrm{H}-141$ \\
\hline
\end{tabular}


Table T10. Electrical resistivity values on discrete samples, Site C0012.

\begin{tabular}{|c|c|c|c|c|c|c|}
\hline \multirow{2}{*}{$\begin{array}{l}\text { Core, section } \\
\text { interval }(\mathrm{cm})\end{array}$} & \multirow{2}{*}{$\begin{array}{l}\text { Depth CSF } \\
(\mathrm{m})\end{array}$} & \multicolumn{3}{|c|}{ Resistivity $(\Omega \mathrm{m})$} & \multirow[b]{2}{*}{$\alpha_{\text {phor }}(\%)$} & \multirow[b]{2}{*}{$\alpha_{\text {pvert }}(\%)$} \\
\hline & & $x$-direction & $y$-direction & $z$-direction & & \\
\hline \multicolumn{7}{|l|}{ 333-C0012E- } \\
\hline $1 \mathrm{X}-1,84-86$ & 500.85 & 1.70 & 1.75 & 3.28 & -3.11 & -62.33 \\
\hline $3 X-1,93-95$ & 519.94 & 2.47 & 2.18 & 3.93 & 12.22 & -51.40 \\
\hline $3 X-4,93-95$ & 522.78 & 2.31 & 2.28 & 3.87 & 1.48 & -51.17 \\
\hline $3 X-8,66-68$ & 526.76 & 9.34 & 9.33 & 9.22 & 0.17 & 1.25 \\
\hline \multicolumn{7}{|l|}{ 333-C0012F- } \\
\hline \multicolumn{7}{|l|}{ 333-C0012G- } \\
\hline $1 \mathrm{R}-2,5-7$ & 516.07 & 2.02 & 1.93 & 3.47 & 4.63 & -54.81 \\
\hline $1 \mathrm{R}-4,51-53$ & 517.62 & 2.34 & 2.48 & 4.53 & -5.69 & -61.12 \\
\hline $2 \mathrm{R}-1,27-29$ & 524.78 & 1.55 & 1.48 & 2.05 & 4.54 & -30.32 \\
\hline $2 \mathrm{R}-2,134-136$ & 526.24 & 27.84 & 22.07 & 16.86 & 23.13 & 38.72 \\
\hline 4R-1, 29-31 & 543.80 & 3.29 & 3.31 & 3.09 & -0.75 & 6.66 \\
\hline $5 R-1,4-6$ & 553.05 & 8.48 & 9.03 & 9.81 & -6.37 & -11.41 \\
\hline 6R-CC, 7-9 & 563.32 & 16.36 & 12.10 & 8.11 & 29.95 & 54.84 \\
\hline 7R-1, 29-31 & 572.30 & 30.40 & 23.15 & 19.14 & 27.09 & 33.23 \\
\hline $8 R-1,34-36$ & 581.85 & 7.22 & 6.49 & 5.25 & 10.62 & 26.55 \\
\hline $9 R-1,8-10$ & 591.09 & 14.03 & 12.80 & 9.88 & 9.16 & 30.36 \\
\hline $10 \mathrm{R}-2,118-120$ & 597.48 & 17.25 & 12.67 & 9.78 & 30.64 & 41.87 \\
\hline $12 \mathrm{R}-2,91-93$ & 612.93 & 14.81 & 11.83 & 11.42 & 22.41 & 15.33 \\
\hline $13 R-1,121-123$ & 616.72 & 37.99 & 19.04 & 14.68 & 66.44 & 64.07 \\
\hline $14 \mathrm{R}-1,22-24$ & 620.73 & 146.34 & 32.11 & 26.91 & 128.03 & 107.30 \\
\hline 15R-1, 29-31 & 625.80 & 47.56 & 18.90 & 18.21 & 86.24 & 58.41 \\
\hline
\end{tabular}


Table T11. Interstitial water geochemistry (raw data), Holes C0012C, C0012D, C0012E and C0012G. (Continued on next page.)

\begin{tabular}{|c|c|c|c|c|c|c|c|c|c|c|c|c|c|c|c|c|c|c|c|c|c|c|}
\hline $\begin{array}{l}\text { Core, } \\
\text { section }\end{array}$ & $\begin{array}{l}\text { Whole-round } \\
\text { length }(\mathrm{cm})\end{array}$ & $\begin{array}{l}\text { Depth } \\
\text { (mbsf) }\end{array}$ & $\mathrm{pH}$ & $\begin{array}{c}\text { Alkalinity } \\
(\mathrm{mM})\end{array}$ & Salinity & $\begin{array}{c}\text { Chlorinity } \\
(\mathrm{mM})\end{array}$ & $\begin{array}{l}\mathrm{Na}^{+} \\
(\mathrm{mM})\end{array}$ & $\begin{array}{l}\mathrm{NH}_{4}^{+} \\
(\mathrm{mM})\end{array}$ & $\begin{array}{l}\mathrm{Ca}^{2+} \\
(\mathrm{mM})\end{array}$ & $\begin{array}{l}\mathrm{Mg}^{2+} \\
(\mathrm{mM})\end{array}$ & $\begin{array}{c}\mathrm{Sr} \\
(\mu \mathrm{M})\end{array}$ & $\begin{array}{c}\mathrm{Li} \\
(\mu \mathrm{M})\end{array}$ & $\begin{array}{c}\mathrm{K}^{+} \\
(\mathrm{mM})\end{array}$ & $\begin{array}{l}\mathrm{PO}_{4}^{3-} \\
(\mu \mathrm{M})\end{array}$ & $\begin{array}{l}\mathrm{SO}_{4}^{2-} \\
(\mathrm{mM})\end{array}$ & $\begin{array}{c}\mathrm{Mn} \\
(\mu \mathrm{M})\end{array}$ & $\begin{array}{c}\mathrm{Br}^{-} \\
(\mathrm{mM})\end{array}$ & $\begin{array}{c}\mathrm{Ba} \\
(\mu \mathrm{M})\end{array}$ & $\begin{array}{c}\mathrm{B} \\
(\mu \mathrm{M})\end{array}$ & $\begin{array}{c}\mathrm{Si} \\
(\mu \mathrm{M})\end{array}$ & $\begin{array}{c}\mathrm{Fe} \\
(\mu \mathrm{M})\end{array}$ & $\begin{array}{c}\mathrm{V} \\
(\mathrm{nM})\end{array}$ \\
\hline \multicolumn{23}{|c|}{$333-C 0012 C-$} \\
\hline $1 \mathrm{H}-2$ & 20 & 2.2 & 7.69 & 2.95 & 35.7 & 552 & 476 & ND & 10.9 & 52.4 & 88.8 & 47 & 11.5 & 3.69 & 28.57 & 7.2 & 0.86 & 0.55 & 462 & 462 & 1.04 & 45.6 \\
\hline $1 \mathrm{H}-3$ & 20 & 3.3 & 7.64 & 2.95 & 35.7 & 552 & 466 & ND & 10.6 & 50.7 & 87.5 & 45 & 11.5 & 4.14 & 28.95 & 8.5 & 0.87 & 0.56 & 485 & 509 & 10.16 & 25.3 \\
\hline $2 \mathrm{H}-2$ & 20 & 6.9 & 7.56 & 2.78 & 35.7 & 556 & 475 & 0.04 & 11.0 & 51.2 & 82.8 & 46 & 11.5 & 4.42 & 36.90 & 12.1 & 1.00 & 0.54 & 484 & 584 & 12.12 & 28.3 \\
\hline $2 \mathrm{H}-4$ & 20 & 9.0 & 7.61 & 3.10 & 35.8 & 555 & 472 & 0.05 & 11.1 & 51.0 & 88.3 & 47 & 11.3 & 4.36 & 28.49 & 13.3 & 0.85 & 0.55 & 464 & 574 & 15.18 & 27.1 \\
\hline $2 \mathrm{H}-6$ & 20 & 11.7 & 7.65 & 3.36 & 35.9 & 556 & 327 & 0.06 & 7.8 & 34.7 & 90.0 & 49 & 8.0 & 3.78 & 28.70 & 15.2 & 0.90 & 0.56 & 461 & 624 & 6.56 & 35.0 \\
\hline $3 \mathrm{H}-3$ & 20 & 17.2 & 7.68 & 2.93 & 36.1 & 561 & 485 & 0.09 & 12.2 & 54.2 & 90.8 & 49 & 11.1 & 3.11 & 30.04 & 16.7 & 0.86 & 0.48 & 443 & 573 & 7.87 & 29.1 \\
\hline $4 \mathrm{H}-4$ & 20 & 27.5 & 7.76 & 3.66 & 36.3 & 565 & 483 & 0.16 & 12.8 & 49.5 & 90.7 & 54 & 11.4 & 3.31 & 26.40 & 27.2 & 0.84 & 0.63 & 422 & 693 & 4.34 & 35.1 \\
\hline $5 \mathrm{H}-3$ & 21 & 35.7 & 7.54 & 3.93 & 36.2 & 562 & 468 & 0.20 & 13.4 & 47.3 & 93.0 & 59 & 9.9 & 3.32 & 28.38 & 45.5 & 0.86 & 0.64 & 443 & 758 & 12.01 & 27.7 \\
\hline $6 \mathrm{H}-4$ & 21.5 & 46.5 & 7.58 & 4.02 & 36.3 & 566 & 481 & 0.25 & 15.1 & 48.0 & 96.7 & 69 & 9.1 & 2.67 & 27.46 & 58.7 & 0.84 & 0.56 & 405 & 726 & 10.53 & 29.3 \\
\hline $8 \mathrm{H}-4$ & 21 & 63.9 & 7.55 & 3.70 & 36.1 & 563 & 484 & 0.34 & 16.6 & 45.8 & 100.6 & 85 & 8.4 & 1.61 & 26.11 & 64.4 & 0.89 & 0.69 & 380 & 836 & 1.51 & 29.3 \\
\hline $9 \mathrm{H}-4$ & 20.5 & 73.8 & 7.88 & 3.55 & 36.2 & 566 & 436 & 0.40 & 15.5 & 40.1 & 101.4 & 92 & 7.7 & 1.45 & 26.30 & 48.2 & 0.87 & 0.77 & 287 & 635 & 1.21 & 30.3 \\
\hline $11 \mathrm{H}-6$ & 21 & 91.5 & 7.55 & 2.68 & 35.3 & 565 & 410 & 0.46 & 25.2 & 29.4 & 121.1 & 145 & 4.8 & 0.87 & 20.20 & 73.7 & 0.85 & 0.75 & 310 & 355 & 1.04 & 25.5 \\
\hline $13 \mathrm{H}-4$ & 27.5 & 105.1 & 7.57 & 1.79 & 34.9 & 563 & 478 & 0.51 & 29.6 & 27.3 & 129.6 & 172 & 4.7 & ND & 16.90 & 79.0 & 0.89 & 1.02 & 317 & 304 & 0.95 & 22.6 \\
\hline $14 \mathrm{H}-2$ & 26.5 & 108.3 & 7.56 & 1.74 & 34.7 & 557 & 468 & 0.50 & 30.4 & 26.3 & 135.3 & 176 & 4.1 & 0.62 & 16.22 & 74.1 & 0.85 & 1.00 & 287 & 287 & 0.92 & 22.8 \\
\hline $15 \mathrm{H}-4$ & 29.5 & 119.3 & 7.43 & 1.84 & 34.9 & 567 & 474 & 0.60 & 32.9 & 21.3 & 145.5 & 196 & 4.3 & 0.47 & 14.27 & 102.4 & 0.89 & 1.11 & 346 & 416 & ND & 22.0 \\
\hline \multicolumn{23}{|c|}{$333-C 0012 D-$} \\
\hline $1 \mathrm{H}-2$ & 19 & 0.6 & 7.72 & 3.58 & 35.6 & 549 & 458 & 0.02 & 10.5 & 50.0 & 86.6 & 44 & 11.0 & 3.62 & 28.43 & 7.8 & 0.92 & 0.50 & 458 & 495 & ND & 37.9 \\
\hline $2 \mathrm{H}-3$ & 26.5 & 119.5 & 7.89 & 1.86 & 34.7 & 564 & 482 & 0.58 & 34.9 & 23.2 & 147.0 & 194 & 4.3 & 0.90 & 14.22 & 71.7 & 0.81 & 1.12 & 264 & 283 & ND & 25.2 \\
\hline $3 \mathrm{H}-3$ & 28.5 & 129.2 & 7.77 & 2.08 & 34.6 & 556 & 408 & 0.59 & 30.6 & 16.5 & 157.3 & 203 & 3.2 & 0.39 & 12.52 & 94.6 & 0.81 & 1.43 & 270 & 362 & ND & 24.3 \\
\hline $4 \mathrm{H}-4$ & 29.5 & 137.3 & 7.74 & 2.56 & 34.5 & 561 & 462 & 0.57 & 36.4 & 16.7 & 159.0 & 208 & 3.3 & 0.56 & 11.01 & 121.6 & 0.80 & 1.40 & 365 & 490 & 0.95 & 25.0 \\
\hline $5 \mathrm{H}-4$ & 30 & 144.4 & 7.79 & 2.49 & 34.2 & 561 & 465 & 0.58 & 38.4 & 15.3 & 161.5 & 215 & 3.1 & 0.75 & 10.15 & 109.3 & 0.91 & 1.45 & 337 & 363 & ND & 26.2 \\
\hline $7 \mathrm{H}-3$ & 20 & 154.6 & 8.27 & 2.34 & 33.9 & 559 & 459 & 0.59 & 39.9 & 12.8 & 171.4 & 215 & 2.9 & 0.50 & 8.73 & 83.2 & 0.89 & 1.79 & 306 & 274 & ND & 23.9 \\
\hline $8 \mathrm{H}-4$ & 29.5 & 160.3 & 7.48 & 1.66 & 33.9 & 551 & 463 & 0.61 & 40.6 & 11.6 & 172.3 & 219 & 2.8 & 0.64 & 7.93 & 119.6 & 0.82 & 1.87 & 420 & 518 & ND & 25.5 \\
\hline $10 \mathrm{H}-3$ & 31 & 168.3 & 8.49 & 1.23 & 33.6 & 556 & 462 & 0.62 & 43.8 & 9.8 & 179.2 & 216 & 2.6 & 0.49 & 6.72 & 48.7 & 0.87 & 1.99 & 261 & 215 & ND & 24.9 \\
\hline $11 \mathrm{H}-2$ & 30 & 171.3 & 8.31 & 1.40 & 33.9 & 562 & 463 & 0.68 & 43.9 & 9.9 & 182.7 & 206 & 2.6 & 0.49 & 6.88 & 53.3 & 0.93 & 1.97 & 254 & 270 & ND & 22.7 \\
\hline $13 \mathrm{H}-4$ & 31 & 178.7 & 8.35 & 0.71 & 33.6 & 557 & 463 & 0.72 & 43.0 & 7.9 & 189.5 & 219 & 2.4 & ND & 5.32 & 46.2 & 0.92 & 2.08 & 272 & 205 & ND & 27.3 \\
\hline \multicolumn{23}{|c|}{ 333-C0012E- } \\
\hline $1 X-3$ & 61 & 502.5 & 5.22 & 0.26 & 40.3 & 603 & 275 & 0.13 & 186.3 & 3.0 & 387.0 & 99 & 0.9 & ND & 5.28 & 23.5 & 0.97 & 10.99 & 147 & 153 & ND & 37.4 \\
\hline $3 X-2$ & 61 & 520.4 & - & - & 44.8 & 640 & 264 & 0.03 & 207.2 & 3.1 & 420.8 & 77 & 0.9 & - & 5.13 & 10.4 & 1.02 & 6.28 & 99 & 169 & ND & 35.7 \\
\hline $3 \mathrm{X}-6$ & 59.5 & 524.1 & - & - & 41.1 & 612 & 291 & 0.03 & 169.5 & 7.2 & 361.4 & 65 & 1.0 & - & 8.69 & 17.2 & 0.98 & 8.72 & 114 & 247 & ND & 27.7 \\
\hline \multicolumn{23}{|c|}{ 333-C0012G- } \\
\hline $1 \mathrm{R}-3$ & 49 & 516.6 & 7.89 & 0.46 & 40.7 & 609 & 300 & 0.09 & 177.1 & 9.7 & 362.2 & 69 & 2.0 & - & 7.95 & 36.2 & 0.96 & 6.73 & 134 & 228 & 0.71 & 28.7 \\
\hline
\end{tabular}

$-=$ not measured, $\mathrm{ND}=$ not detected. 


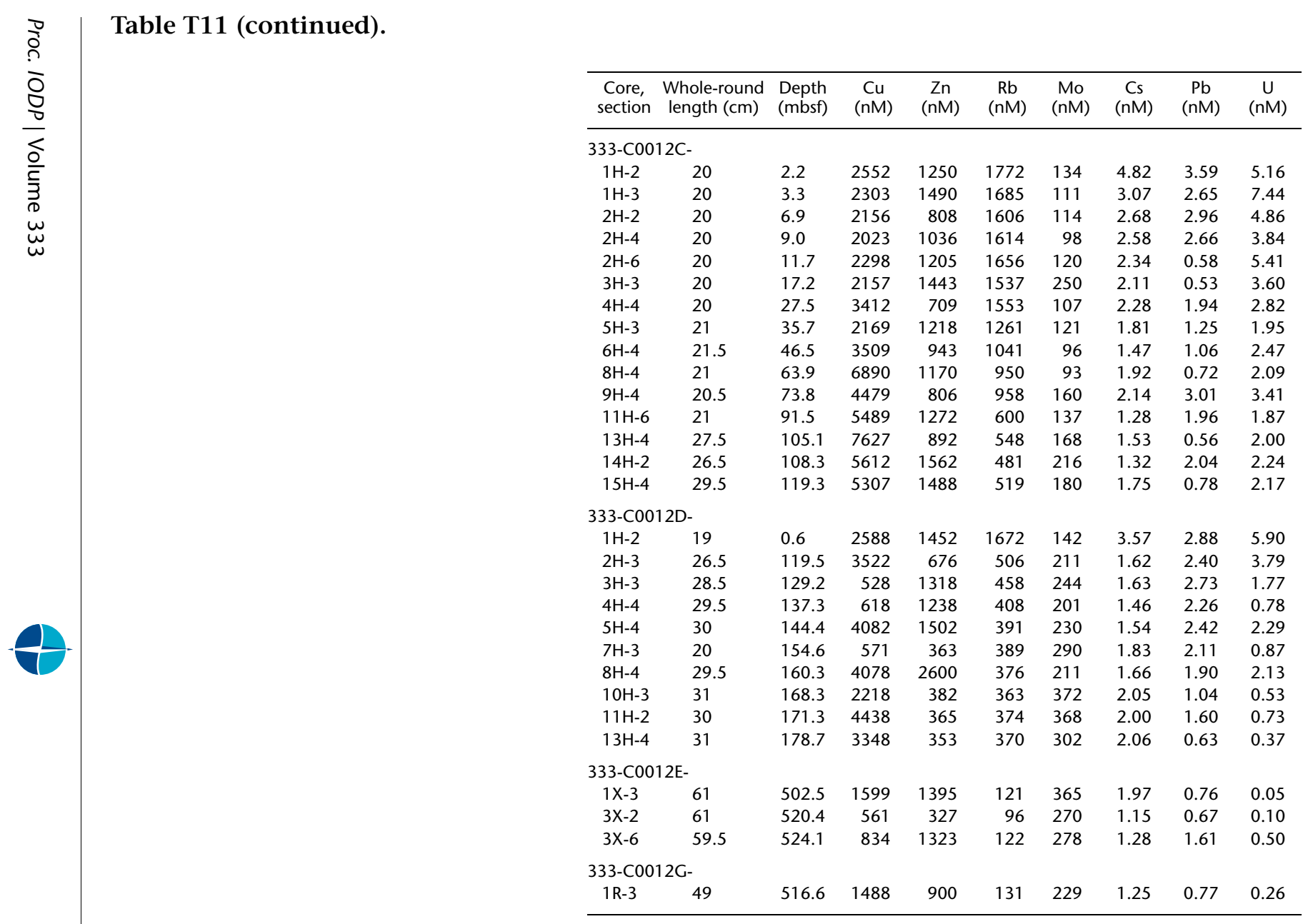


Table T12. Headspace methane concentration, ethane concentration, and the ratios of methane to ethane (C1/ C2) ratios, Holes C0012C, C0012D, C0012E, and C0012G.

\begin{tabular}{|c|c|c|c|c|}
\hline $\begin{array}{l}\text { Core, section, } \\
\text { interval }(\mathrm{cm})\end{array}$ & $\begin{array}{l}\text { Depth } \\
\text { (mbsf) }\end{array}$ & $\begin{array}{l}\text { Methane } \\
(\text { ppmv) }\end{array}$ & $\begin{array}{l}\text { Ethane } \\
\text { (ppmv) }\end{array}$ & $\mathrm{C} 1 / \mathrm{C} 2$ \\
\hline \multicolumn{5}{|l|}{ 333-C0012C- } \\
\hline $1 \mathrm{H}-1,136.5-140.5$ & 1.3 & 0.0 & 0.0 & 100,000 \\
\hline $2 \mathrm{H}-1,137.5-141.5$ & 5.8 & 0.0 & 0.0 & 100,000 \\
\hline $3 \mathrm{H}-1,136.5-140.5$ & 15.3 & 0.0 & 0.0 & 100,000 \\
\hline $4 \mathrm{H}-1,137.5-141.5$ & 24.8 & 0.0 & 0.0 & 100,000 \\
\hline $5 \mathrm{H}-1,135.5-139.5$ & 34.3 & 0.0 & 0.0 & 100,000 \\
\hline $6 \mathrm{H}-1,137.5-141.5$ & 43.8 & 0.0 & 0.0 & 100,000 \\
\hline $8 \mathrm{H}-1,137-141$ & 61.3 & 0.0 & 0.0 & 100,000 \\
\hline $9 \mathrm{H}-1,141.5-144.5$ & 70.9 & 0.0 & 0.0 & 100,000 \\
\hline $10 \mathrm{H}-1,138-142$ & 80.2 & 0.0 & 0.0 & 100,000 \\
\hline $11 \mathrm{H}-1,138-142$ & 87.8 & 0.0 & 0.0 & 100,000 \\
\hline $12 \mathrm{H}-1,138-142$ & 95.3 & 0.0 & 0.0 & 100,000 \\
\hline $13 \mathrm{H}-1,137-141$ & 103.1 & 0.0 & 0.0 & 100,000 \\
\hline $14 \mathrm{H}-1,76.5-80.5$ & 109.3 & 0.0 & 0.0 & 100,000 \\
\hline $15 \mathrm{H}-1,138-142$ & 117.1 & 0.0 & 0.0 & 100,000 \\
\hline \multicolumn{5}{|l|}{ 333-C0012D- } \\
\hline $2 \mathrm{H}-1,137-141$ & 119.2 & 0.0 & 0.0 & 100,000 \\
\hline $3 \mathrm{H}-1,138-142$ & 127.8 & 0.0 & 0.0 & 100,000 \\
\hline $4 \mathrm{H}-1,137-141$ & 135.1 & 0.0 & 0.0 & 100,000 \\
\hline $5 \mathrm{H}-1,136.5-140.5$ & 142.2 & 0.0 & 0.0 & 100,000 \\
\hline $6 \mathrm{H}-1,137-141$ & 147.6 & 0.0 & 0.0 & 100,000 \\
\hline $7 \mathrm{H}-1,136.5-140.5$ & 153.3 & 0.0 & 0.0 & 100,000 \\
\hline $8 \mathrm{H}-1,136.5-140.5$ & 158.8 & 0.0 & 0.0 & 100,000 \\
\hline $9 \mathrm{H}-1,137-141$ & 163.6 & 0.0 & 0.0 & 100,000 \\
\hline $10 \mathrm{H}-1,137.5-141.5$ & 167.7 & 0.0 & 0.0 & 100,000 \\
\hline $11 \mathrm{H}-1,134.5-138.5$ & 171.3 & 0.0 & 0.0 & 100,000 \\
\hline $12 \mathrm{H}-1,87-91$ & 174.1 & 2.5 & 0.0 & 100,000 \\
\hline $13 \mathrm{H}-1,136.5-140.5$ & 176.9 & 0.0 & 0.0 & 100,000 \\
\hline \multicolumn{5}{|l|}{ 333-C0012E- } \\
\hline $1 X-1,136-140$ & 501.4 & 119.7 & 1.9 & 64 \\
\hline $2 X-1,53-57$ & 510.0 & 23.3 & 0.0 & 100,000 \\
\hline $3 X-1,137-141$ & 520.4 & 86.6 & 1.5 & 59 \\
\hline \multicolumn{5}{|l|}{ 333-C0012G- } \\
\hline $1 \mathrm{R}-4,0-4$ & 517.1 & 15.7 & 0.0 & 100,000 \\
\hline
\end{tabular}

Methane and ethane are set at 0.0 when below detection. $C 1 / C 2$ is set at 100,000 when ethane concentration is below detection. 
Table T13. Bulk sediment calcium carbonate and elemental analyses data, Holes C0012C, C0012D, C0012E, and C0012G. (Continued on next page.)

\begin{tabular}{|c|c|c|c|c|c|c|}
\hline $\begin{array}{l}\text { Core, section, } \\
\text { interval }(\mathrm{cm})\end{array}$ & $\begin{array}{l}\text { Depth } \\
\text { (mbsf) }\end{array}$ & $\begin{array}{l}\mathrm{CaCO}_{3} \\
\text { (wt\%) }\end{array}$ & $\begin{array}{l}\text { TOC } \\
\text { (wt\%) }\end{array}$ & $\begin{array}{c}\text { TN } \\
(w t \%)\end{array}$ & $\mathrm{TOC} / \mathrm{TN}_{\mathrm{at}}$ & $\begin{array}{c}\text { TS } \\
(w t \%)\end{array}$ \\
\hline \multicolumn{7}{|l|}{ 333-C0012C- } \\
\hline $1 \mathrm{H}-2,113-115$ & 2.4 & 10.51 & 0.14 & 0.03 & 5.8 & 0.06 \\
\hline $1 \mathrm{H}-2,123-124$ & 2.5 & 7.87 & 0.22 & 0.03 & 7.4 & 0.06 \\
\hline $1 \mathrm{H}-3,95-97$ & 3.5 & 14.63 & 0.36 & 0.04 & 9.3 & 0.07 \\
\hline $2 \mathrm{H}-2,128.5-130.5$ & 7.1 & 16.45 & 0.47 & 0.05 & 10.6 & 0.06 \\
\hline $2 \mathrm{H}-3,124.5-125.5$ & 8.3 & 6.58 & 0.34 & 0.05 & 8.3 & 0.07 \\
\hline $2 \mathrm{H}-4,70-72$ & 9.2 & 9.44 & 0.36 & 0.05 & 8.3 & 0.15 \\
\hline $2 \mathrm{H}-5,121.5-122.5$ & 11.0 & 9.69 & 0.16 & 0.03 & 5.5 & 0.06 \\
\hline $2 \mathrm{H}-6,78-80$ & 11.9 & 3.24 & 0.41 & 0.06 & 8.4 & 0.34 \\
\hline $3 \mathrm{H}-3,75-77$ & 17.4 & 4.52 & 0.28 & 0.05 & 7.2 & 0.35 \\
\hline $3 \mathrm{H}-5,8-9$ & 19.4 & 0.57 & 0.35 & 0.06 & 7.4 & 0.22 \\
\hline $3 \mathrm{H}-6,119.5-120.5$ & 21.8 & 3.25 & 0.26 & 0.05 & 6.5 & 0.23 \\
\hline $4 \mathrm{H}-2,125.5-126.5$ & 26.0 & 0.36 & 0.33 & 0.06 & 6.8 & 0.26 \\
\hline $4 \mathrm{H}-3,28-29$ & 26.4 & 0.43 & 0.31 & 0.05 & 6.8 & 0.40 \\
\hline $4 \mathrm{H}-4,20-22$ & 27.7 & 0.89 & 0.27 & 0.05 & 6.7 & 0.15 \\
\hline $4 \mathrm{H}-5,100-101$ & 28.6 & 0.59 & 0.42 & 0.06 & 7.9 & 0.17 \\
\hline $5 \mathrm{H}-2,121-122$ & 35.5 & 0.29 & 0.40 & 0.06 & 7.9 & 0.15 \\
\hline $5 \mathrm{H}-3,21-23$ & 35.9 & 0.80 & 0.43 & 0.06 & 8.7 & 0.49 \\
\hline $5 \mathrm{H}-7,125-126$ & 41.3 & 0.92 & 0.46 & 0.07 & 8.3 & 0.30 \\
\hline $6 \mathrm{H}-2,79-80$ & 44.6 & 1.12 & 0.35 & 0.05 & 7.7 & 0.18 \\
\hline $6 \mathrm{H}-4,21.5-23.5$ & 46.7 & 0.77 & 0.39 & 0.06 & 8.0 & 0.30 \\
\hline $6 \mathrm{H}-6,126.5-127.5$ & 49.2 & 1.00 & 0.52 & 0.07 & 8.4 & 0.31 \\
\hline $6 \mathrm{H}-8,29-30$ & 50.9 & 0.29 & 0.38 & 0.06 & 7.0 & 0.22 \\
\hline $6 \mathrm{H}-8,90-91$ & 51.5 & 0.34 & 0.33 & 0.06 & 6.9 & 0.25 \\
\hline $8 \mathrm{H}-1,125-126$ & 61.2 & 1.76 & 0.29 & 0.05 & 6.4 & 0.13 \\
\hline $8 \mathrm{H}-2,121.5-122.5$ & 62.4 & 4.99 & 0.25 & 0.05 & 5.9 & 0.13 \\
\hline $8 \mathrm{H}-4,21-23$ & 64.1 & 6.93 & 0.22 & 0.05 & 5.5 & 0.09 \\
\hline $9 \mathrm{H}-1,80-81$ & 70.3 & 5.94 & 0.27 & 0.05 & 6.0 & 0.07 \\
\hline $9 \mathrm{H}-4,20.5-22.5$ & 74.0 & 1.49 & 0.26 & 0.05 & 5.5 & 0.14 \\
\hline $9 \mathrm{H}-6,66-67$ & 76.1 & 1.82 & 0.21 & 0.05 & 4.5 & 0.08 \\
\hline $9 \mathrm{H}-7,50-51$ & 77.3 & 9.82 & 0.22 & 0.04 & 5.7 & 0.07 \\
\hline $10 \mathrm{H}-1,125-126$ & 80.1 & 1.61 & 0.20 & 0.05 & 5.1 & 0.16 \\
\hline $10 \mathrm{H}-2,20-21$ & 80.4 & 7.59 & 0.23 & 0.05 & 5.9 & 0.05 \\
\hline $10 \mathrm{H}-5,42-43$ & 82.2 & 12.15 & 0.35 & 0.05 & 7.7 & 0.09 \\
\hline $10 \mathrm{H}-9,63-64$ & 85.6 & 0.55 & 0.24 & 0.06 & 5.0 & 0.13 \\
\hline $10 \mathrm{H}-9,107-108$ & 86.0 & 2.05 & 0.23 & 0.06 & 4.7 & 0.41 \\
\hline $11 \mathrm{H}-4,105-106$ & 90.8 & 0.55 & 0.28 & 0.06 & 5.6 & 0.12 \\
\hline $11 \mathrm{H}-6,21-23$ & 91.7 & 3.88 & 0.25 & 0.05 & 5.9 & 0.09 \\
\hline $11 \mathrm{H}-7,55-56$ & 92.2 & 9.04 & 0.29 & 0.05 & 6.6 & 0.08 \\
\hline $11 \mathrm{H}-8,20-21$ & 92.6 & 1.40 & 0.27 & 0.06 & 5.1 & 0.17 \\
\hline $12 \mathrm{H}-3,37-38$ & 96.9 & 11.38 & 0.20 & 0.05 & 5.1 & 0.07 \\
\hline $13 \mathrm{H}-1,60-61$ & 102.5 & 5.78 & 0.26 & 0.06 & 5.5 & 0.11 \\
\hline $13 \mathrm{H}-2,125-126$ & 104.1 & 7.45 & 0.32 & 0.06 & 6.7 & 0.15 \\
\hline $13 \mathrm{H}-4,27.5-29.5$ & 105.3 & 18.20 & 0.21 & 0.04 & 5.7 & 0.07 \\
\hline $13 \mathrm{H}-5,120-121$ & 106.3 & 6.48 & 0.20 & 0.05 & 4.4 & 0.16 \\
\hline $14 \mathrm{H}-2,26.5-28.5$ & 108.6 & 8.48 & 0.21 & 0.05 & 5.0 & 0.11 \\
\hline $15 \mathrm{H}-2,125.5-126.5$ & 118.1 & 2.85 & 0.28 & 0.06 & 5.3 & 0.14 \\
\hline $15 \mathrm{H}-4,29.5-31.5$ & 119.6 & 7.33 & 0.23 & 0.05 & 5.1 & 0.13 \\
\hline $15 \mathrm{H}-5,126-127$ & 120.6 & 5.44 & 0.28 & 0.06 & 6.0 & 0.05 \\
\hline \multicolumn{7}{|l|}{ 333-C0012D- } \\
\hline $1 \mathrm{H}-1,24.5-25.5$ & 0.2 & 12.68 & 0.21 & 0.04 & 6.7 & 0.05 \\
\hline $1 \mathrm{H}-2,19-21$ & 0.8 & 15.06 & 0.25 & 0.04 & 7.5 & 0.05 \\
\hline $2 \mathrm{H}-3,26.5-28.5$ & 119.7 & 5.26 & 0.27 & 0.06 & 5.4 & 0.13 \\
\hline $3 \mathrm{H}-2,125.5-126.5$ & 129.1 & 0.61 & 0.23 & 0.06 & 4.4 & 0.20 \\
\hline $3 \mathrm{H}-3,28.5-30.5$ & 129.5 & 4.70 & 0.31 & 0.06 & 6.0 & 0.13 \\
\hline $3 \mathrm{H}-6,100-101$ & 133.2 & 6.56 & 0.35 & 0.06 & 7.0 & 0.12 \\
\hline $4 \mathrm{H}-2,125.5-126.5$ & 136.2 & 3.39 & 0.27 & 0.06 & 5.6 & 0.09 \\
\hline $4 \mathrm{H}-4,29.5-31.5$ & 137.5 & 0.40 & 0.29 & 0.06 & 5.3 & 0.12 \\
\hline $4 \mathrm{H}-5,120.5-121.5$ & 138.6 & 0.57 & 0.25 & 0.06 & 4.7 & 0.06 \\
\hline $5 \mathrm{H}-2,108-109$ & 143.2 & 1.27 & 0.32 & 0.06 & 5.9 & 0.38 \\
\hline $5 \mathrm{H}-3,15-16$ & 143.7 & 1.21 & 0.28 & 0.07 & 5.1 & 0.22 \\
\hline $5 \mathrm{H}-5,30-32$ & 144.6 & 0.38 & 0.30 & 0.07 & 5.3 & 0.16 \\
\hline $7 \mathrm{H}-3,29-31$ & 154.8 & 0.21 & 0.25 & 0.05 & 5.3 & 0.08 \\
\hline 7H-5, 20-21 & 156.4 & 0.22 & 0.32 & 0.06 & 5.8 & 0.13 \\
\hline $8 \mathrm{H}-3,56.5-57.5$ & 160.1 & 1.29 & 0.33 & 0.07 & 5.9 & 0.18 \\
\hline $8 \mathrm{H}-4,29.5-31.5$ & 160.6 & 1.31 & 0.35 & 0.07 & 6.1 & 0.09 \\
\hline $9 \mathrm{H}-3,119.5-120.5$ & 165.7 & 0.58 & 0.29 & 0.06 & 5.2 & 0.10 \\
\hline
\end{tabular}


Table T13 (continued).

\begin{tabular}{|c|c|c|c|c|c|c|}
\hline $\begin{array}{l}\text { Core, section, } \\
\text { interval }(\mathrm{cm})\end{array}$ & $\begin{array}{l}\text { Depth } \\
\text { (mbsf) }\end{array}$ & $\begin{array}{l}\mathrm{CaCO}_{3} \\
\text { (wt\%) }\end{array}$ & $\begin{array}{c}\text { TOC } \\
\text { (wt\%) }\end{array}$ & $\begin{array}{c}\text { TN } \\
(w t \%)\end{array}$ & $\mathrm{TOC} / \mathrm{TN}_{\mathrm{at}}$ & $\begin{array}{c}\text { TS } \\
\text { (wt\%) }\end{array}$ \\
\hline $10 \mathrm{H}-2,8-9$ & 167.8 & 2.34 & 0.31 & 0.07 & 5.5 & 0.21 \\
\hline $10 \mathrm{H}-2,88.5-89.5$ & 168.2 & 2.44 & 0.35 & 0.06 & 6.6 & 0.06 \\
\hline $10 \mathrm{H}-3,31-33$ & 168.5 & 1.76 & 0.32 & 0.06 & 5.9 & 0.14 \\
\hline $11 \mathrm{H}-2,30-32$ & 171.5 & 0.51 & 0.28 & 0.06 & 5.1 & 0.13 \\
\hline $12 \mathrm{H}-3,27-29$ & 174.6 & 9.64 & 0.29 & 0.06 & 6.1 & 0.07 \\
\hline $13 \mathrm{H}-1,124.5-125.5$ & 176.9 & 2.65 & 0.35 & 0.05 & 7.4 & 0.09 \\
\hline $13 \mathrm{H}-4,31-33$ & 178.9 & 4.83 & 0.27 & 0.04 & 7.1 & 0.11 \\
\hline \multicolumn{7}{|l|}{ 333-C0012E- } \\
\hline $1 X-1,24-25$ & 500.2 & 7.02 & 0.10 & 0.03 & 4.0 & 0.02 \\
\hline $1 X-3,61-63$ & 503.1 & 17.10 & 0.07 & 0.03 & 3.2 & 0.00 \\
\hline $3 X-1,113.5-118$ & 520.1 & 29.68 & 0.03 & 0.02 & 1.3 & 0.00 \\
\hline $3 X-2,61-63$ & 521.0 & 29.82 & 0.03 & 0.02 & 1.6 & 0.00 \\
\hline $3 X-3,36-37$ & 521.4 & 45.06 & 0.08 & 0.02 & 5.1 & 0.00 \\
\hline $3 X-4,8.5-9.5$ & 521.9 & 14.88 & 0.05 & 0.03 & 1.8 & 0.01 \\
\hline $3 X-4,139.5-140.5$ & 523.2 & 11.53 & 0.04 & 0.02 & 1.8 & 0.00 \\
\hline $3 X-6,59.5-61.5$ & 524.7 & 17.37 & 0.03 & 0.03 & 1.4 & 0.00 \\
\hline \multicolumn{7}{|l|}{ 333-C0012G- } \\
\hline $1 \mathrm{R}-3,49-51$ & 517.1 & 13.02 & 0.03 & 0.02 & 1.7 & 0.01 \\
\hline $1 R-4,101.5-104.5$ & 518.1 & 16.59 & 0.05 & 0.03 & 2.0 & 0.01 \\
\hline
\end{tabular}

$\mathrm{TOC}=$ total organic carbon, $\mathrm{TN}=$ total nitrogen, $\mathrm{TOC} / \mathrm{TN}_{\mathrm{at}}=$ atomic ratios of $\mathrm{TOC}$ to $\mathrm{TN}, \mathrm{TS}=$ total sulfur. 
Table T14. Rock-Eval pyrolysis data, Holes C0012C and C0012D.

\begin{tabular}{|c|c|c|c|c|c|c|}
\hline $\begin{array}{l}\text { Core, section, } \\
\text { interval }(\mathrm{cm})\end{array}$ & $\begin{array}{l}\text { Depth } \\
\text { (mbsf) }\end{array}$ & $\begin{array}{c}\mathrm{S} 1 \\
\text { (mg HC/g sediment) }\end{array}$ & $\begin{array}{c}\mathrm{S} 2 \\
\text { (mg HC/g sediment) }\end{array}$ & $\begin{array}{l}T_{\max } \\
\left({ }^{\circ} \mathrm{C}\right)\end{array}$ & $\begin{array}{l}\text { Hydrogen index } \\
(\mathrm{mg} \mathrm{HC} / \mathrm{g} \text { TOC) }\end{array}$ & $\begin{array}{l}\text { Production } \\
\text { index }\end{array}$ \\
\hline \multicolumn{7}{|l|}{ 333-C0012C- } \\
\hline $1 \mathrm{H}-3,95-97$ & 3.5 & 0.01 & 0.07 & 434 & 20 & 0.17 \\
\hline $2 \mathrm{H}-4,70-72$ & 9.2 & 0.01 & 0.09 & 412 & 25 & 0.08 \\
\hline $3 \mathrm{H}-6,119.5-120.5$ & 21.8 & 0.00 & 0.12 & 607 & 46 & 0.03 \\
\hline $4 \mathrm{H}-5,100-101$ & 28.6 & 0.01 & 0.35 & 605 & 85 & 0.03 \\
\hline $5 \mathrm{H}-2,121-122$ & 35.5 & 0.01 & 0.32 & 606 & 81 & 0.02 \\
\hline $5 \mathrm{H}-3,21-23$ & 35.9 & 0.02 & 0.29 & 606 & 67 & 0.08 \\
\hline $5 \mathrm{H}-7,125-126$ & 41.3 & 0.01 & 0.30 & 604 & 66 & 0.04 \\
\hline $6 \mathrm{H}-8,29-30$ & 50.9 & 0.02 & 0.33 & 604 & 86 & 0.05 \\
\hline $9 \mathrm{H}-4,20.5-22.5$ & 74.0 & 0.00 & 0.21 & 606 & 81 & 0.01 \\
\hline $10 \mathrm{H}-5,42-43$ & 82.2 & 0.01 & 0.12 & 387 & 37 & 0.04 \\
\hline $11 \mathrm{H}-7,55-56$ & 92.2 & 0.01 & 0.06 & 390 & 21 & 0.18 \\
\hline $13 \mathrm{H}-2,125-126$ & 104.1 & 0.01 & 0.09 & 414 & 28 & 0.06 \\
\hline $15 \mathrm{H}-2,125.5-126.5$ & 118.1 & 0.00 & 0.07 & 404 & 25 & 0.03 \\
\hline $15 \mathrm{H}-5,125-126$ & 120.6 & 0.00 & 0.07 & 416 & 30 & 0.02 \\
\hline \multicolumn{7}{|l|}{ 333-C0012D- } \\
\hline $1 \mathrm{H}-2,19-21$ & 0.8 & 0.01 & 0.04 & 316 & 16 & 0.11 \\
\hline $3 \mathrm{H}-3,28-30$ & 129.5 & 0.02 & 0.11 & 407 & 36 & 0.13 \\
\hline $4 \mathrm{H}-4,29.5-31.5$ & 137.5 & 0.00 & 0.12 & 419 & 43 & 0.03 \\
\hline $5 \mathrm{H}-5,30-32$ & 144.6 & 0.00 & 0.11 & 417 & 38 & 0.01 \\
\hline $8 \mathrm{H}-3,56.5-57.5$ & 160.1 & 0.00 & 0.08 & 424 & 25 & 0.01 \\
\hline $8 \mathrm{H}-4,29.5-31.5$ & 160.6 & 0.00 & 0.10 & 420 & 30 & 0.04 \\
\hline $10 \mathrm{H}-2,8-9$ & 167.8 & 0.01 & 0.07 & 405 & 23 & 0.11 \\
\hline $11 \mathrm{H}-2,30-32$ & 171.5 & 0.00 & 0.06 & 427 & 23 & 0.01 \\
\hline $13 \mathrm{H}-4,31-33$ & 178.9 & 0.00 & 0.04 & 413 & 15 & 0.01 \\
\hline
\end{tabular}

$\mathrm{HC}=$ hydrocarbon, $\mathrm{TOC}=$ total organic carbon. 